\title{
Fra kollektiv til konnektiv handling?
}

Nye former for samfunnsengasjement og kollektiv handling i Norge.

Bernard Enjolras og Ivar Eimhjellen (red.)

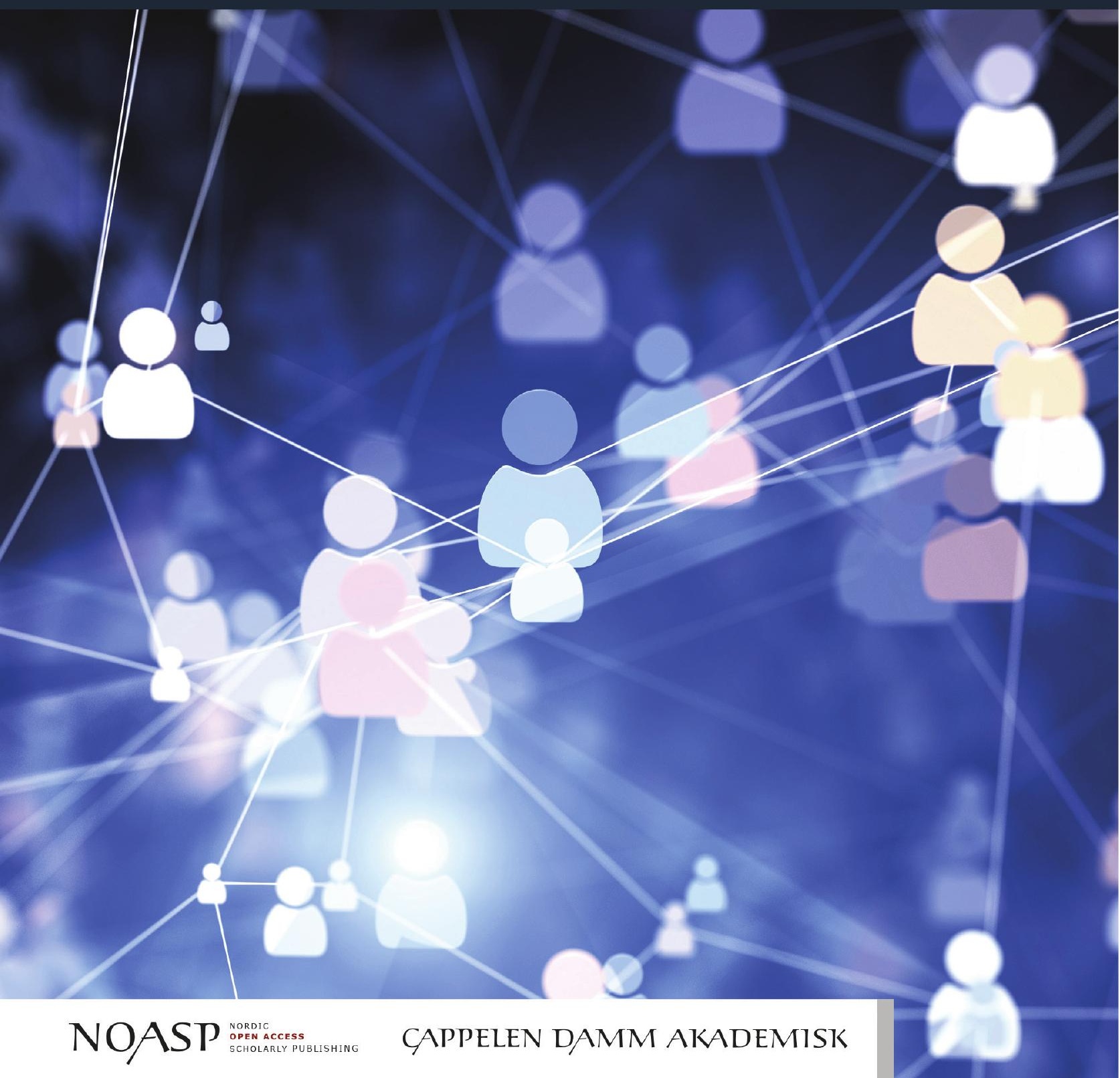




\section{Fra kollektiv til konnektiv handling?}

Nye former for samfunnsengasjement og kollektiv handling i Norge 

Bernard Enjolras og Ivar Eimhjellen (red.)

\section{Fra kollektiv til konnektiv handling?}

Nye former for samfunnsengasjement og kollektiv handling i Norge 
(c) 2018 Bernard Enjolras, Ivar Eimhjellen, Audun beyer, Audun Fladmoe, Steinar Gjerde, Kari Steen-Johnsen, Kristin Strømsnes, Synne Sætrang, Marianne Takle og Guro Ødegård

Dette verket omfattes av bestemmelsene i Lov om opphavsretten til åndsverk m.v. av 1961. Verket utgis Open Access under betingelsene i Creative Commons-lisensen CC BY-NC 4.0. Denne lisensen lar andre dele og bearbeide verket for ikke-kommersielle formål, under forutsetning av at det oppgis korrekt kreditering, lenke til lisens og indikasjon på om endringer er blitt gjort. Du kan gjøre dette på enhver rimelig måte, men uten at det kan forstås slik at lisensgiver bifaller deg eller din bruk av materialet. Lisensvilkår: https:// creativecommons.org/licenses/by-nc/4.0/legalcode.no

Boka er utgitt med støtte fra Institutt for samfunnsforskning.

ISBN PDF: 978-82-02-59042-0

ISBN EPUB: 978-82-02-62614-3

ISBN HTML: 978-82-02-62615-0

ISBN XML: 978-82-02-62616-7

DOI: https://doi.org/10.23865/noasp.45

Dette er en fagfellevurdert antologi.

Cover Design: Cappelen Damm

Forsidebilde: iLexx/Getty Images. Bildet er brukt med tillatelse fra Getty Images, og er ikke omfattet av CC-BY-NC 4.0-lisens. Bildet kan ikke gjenbrukes uten tillatelse fra Getty Images.

Cappelen Damm Akademisk/NOASP

noasp@cappelendamm.no 


\section{Innhold}

Kapittel 1: Nye former for samfunnsengasjement og kollektiv handling.......... 7 Bernard Enjolras og Ivar Eimhjellen

Kapittel 2: Politiske aksjoner i Norge: Hvilken rolle spiller organisasjonene? .31

Kristin Strømsnes og Steinar Gjerde

Kapittel 3: Demokratisering av deltakelse gjennom sosiale medier. Sosial ulikhet i nordmenns digitale samfunnsengasjement .63 Ivar Eimhjellen og Jørn Ljunggren

Kapittel 4: Forholdet mellom online og offline deltakelse i frivillige organisasjoner 101

Bernard Enjolras, Kari Steen-Johnsen og Audun Beyer

Kapittel 5: Tradisjonelle organisasjoner og nye frivillige initiativ i flyktningsituasjonen høsten 2015. Mobilisering eller forsterkning av eksisterende skiller? 127

Audun Fladmoe

Kapittel 6: På Facebook for flyktninger. En casestudie av Refugees Welcome-nettverket i Norge 151

Synne Sætrang

Kapittel 7: Flyktningengasjement i sosiale medier. Et mediepraksisperspektiv på flyktningsituasjonen i 2015 189

Ivar Eimhjellen

Kapittel 8: Refleksiv institusjonalisering. Nytt frivillig engasjement i brytningen mellom endring og stabilitet

Ivar Eimhjellen

Kapittel 9: Nasjonale organisasjoners bruk av sosiale medier.

Muligheter og barrierer for bruk 235

Audun Beyer og Kari Steen-Johnsen 
Kapittel 10: Nye former for tilhørighet. Migrantorganisasjoner for barn og ungdom i en norsk sivilsamfunnskontekst..

Guro Ødegård og Marianne Takle

Biografier . .299 


\title{
Nye former for \\ samfunnsengasjement og kollektiv handling
}

\author{
Bernard Enjolras \\ Institutt for samfunnsforskning \\ Ivar Eimhjellen \\ NORCE
}

\begin{abstract}
This chapter introduces the book's main topics and analytical frame. With the development of societal meta-processes of change such as digitalization, individualization and globalization, the condition of collective action are under transformation. The main question, addressed by this book, is whether a new form of collective action - connective action - can be empirically identified when looking at the late developments in Norway. The need for formal organizations and selective incentives has been emphasized as a solution to the "collective action problem". Digitalization, by enabling "organizing without organizations" is expected to enhance new forms of collective action that are more individualized and do not require formal organizations. Additionally, since digital networks cross territorial boundaries, collective action is expected to take a transnational character. With such a backdrop, the contributions assembled in this book, based on extensive empirical investigations, examine the extent to which digitalization transforms civic engagement, whether the boundary between volunteerism and political activism are becoming increasingly blurred, whether new organizing forms are emerging in the wake of digitalization, and whether it is possible to identify new forms of transnational collective action. Taken together, the contributions to this book do not support the emergence of a new form of collective action. On the contrary, in spite of the transformations affecting the forms of collective action and civic engagement, the empirical evidence emphasize the continued importance of the infrastructure constituted of civil society organizations for supporting collective action.
\end{abstract}

Keywords: collective action, civic engagement, individualization, digitalization, connective action, transnational.

Sitering av denne artikkelen: Enjolras, B., \& Eimhjellen, I. (2018). Nye former for samfunnsengasjement og kollektiv handling. I B. Enjolras \& I. Eimhjellen (Red.), Fra kollektiv til konnektiv handling? Nye former for samfunnsengasjement og kollektiv handling $i$ Norge (s. 7-30). Oslo: Cappelen Damm Akademisk. https://doi.org/10.23865/noasp.45.ch1 Lisens: CC BY-NC 4.0 


\section{Innledning}

«Millionene strømmer inn til Leger uten grenser» kunne man lese i Bergensavisen 21.03.2018. Bakgrunnen var en Facebook-aksjon til inntekt for Leger uten grenser, som ble startet fem dager før. Initiativtakeren til aksjonen hadde spontant opprettet en innsamling som reaksjon på blomsterstøtten som daværende justisminister Sylvi Listhaug fikk etter hennes Facebook-innlegg om at Arbeiderpartiet setter terroristers rettssikkerhet foran nasjonens sikkerhet. Innsamlingsaksjonen spredte seg raskt og fikk stor oppmerksomhet. På bare fire dager donerte mer enn 80 ooo nordmenn til sammen over 17,5 millioner kroner til Leger uten grenser, noe som trolig er det største beløpet til en ideell organisasjon som er samlet inn på denne måten i Norge. At en innsamlingsaksjon som ble opprettet spontant av en enkeltperson, kunne få et så stort omfang og på så kort tid illustrerer den store mobiliseringskraften for kollektivt engasjement som ligger i sosiale medier. Sosiale medier har på denne måten skapt nye muligheter for samfunnsengasjement og kollektiv handling i Norge.

Med Facebook i spissen utgjør sosiale medier nå egne mobiliseringsverktøy og deltakelsesarenaer som kan fungere som selvstendige infrastrukturer for organisering og mobilisering av kollektive handlinger. Dette står i kontrast til de tradisjonelle måtene å engasjere og organisere samfunnsengasjement og deltakelse i kollektive handlinger på. I Norge har slikt engasjement helt siden 1800-tallet vært knyttet til sosiale bevegelser og det organiserte livet innenfor frivillige organisasjoner (Sivesind mfl., 2002). De fremvokste digitale handlingsmulighetene er del av en større digitaliseringsprosess der nye informasjons- og kommunikasjonsteknologier knyttet til internett, sosiale medier og mobiltelefoner har endret våre kommunikasjonsmuligheter, praksiser og vår sosiale organisering. Kommunikasjon og koordinering gjennom digitale nettverk har nå blitt en sentral måte å organisere på. Teoretikere som Castells (1996, 2000, 2001) og van Dijk (2006) hevder at denne nye formen for organisering, betegnet som nettverkssamfunnet, skiller seg fra tidligere organiseringsformer ved at kollektiver blir erstattet av individer koblet i nettverk, at sosiale relasjoner blir både lokale og globale, og at samfunn blir mer heterogene, mindre sentralisere, mindre vertikalt integrerte og mer horisontalt differensierte. 
Tett koblet til og forsterket av digitaliseringen har også de forutgående prosessene av individualisering og globalisering endret konteksten for samfunnsengasjement og kollektiv handling i Norge. Som del av en vestlig utviklingstrend har det norske samfunnet de siste tiårene blitt mer individualisert og mangfoldiggjort. Individet har blitt mer løsrevet fra industrisamfunnets tradisjonelle sosiale roller, identiteter og levemåter, og er i større grad enn tidligere nødt til selv å definere sine roller, identiteter, og levemåter (Beck, 1992). Individet og individsentrerte verdier er nå mer sentrale enn før for menneskers livsutfoldelse, kommunikasjon og samfunnsdeltakelse (Giddens, 1991; Ingelhart, 1990). Globaliseringen har på sin side brakt med seg en økende betydning av overnasjonale politiske institusjoner og transnasjonale bedrifter, samt økende migrasjonsstrømmer og globale kulturelle trender. Mange samfunnsutfordringer, som klima, miljø, fattigdom og ulikhet, er også av globalt omfang, og samfunnsengasjement og kollektiv organisering har i økende grad blitt preget av slike transnasjonale spørsmål, relasjoner og bevegelser. Globalisering og digitale medier gjør at vi lettere blir påvirket av hva som skjer utenfor Norges grenser, noe som igjen påvirker hva vi er opptatt av, og hva som engasjerer oss, både her hjemme og utenfor Norge. Den globale flyten av mennesker gjennom migrasjon er for eksempel en viktig kilde til humanitært og politisk engasjement, både gjennom innsamlingsaksjoner til norske og internasjonale organisasjoner og gjennom frivillig og politisk arbeid, både i Norge og utenlands.

I denne boken skal vi ta for oss flere eksempler på hvordan samfunnsengasjement og kollektiv handling påvirkes av de tre nevnte samfunnsprosessene: globalisering, individualisering og digitalisering. Ett sentralt eksempel i boken handler om det store samfunnsengasjementet som ble utløst av flyktningstrømmen til Europa og Norge i 2015 med utgangspunkt i krigen i Syria. Et av de sterkeste bildene på denne flyktningsituasjonen var bildet av den druknede gutten Aylan på stranden i Bodrum i Tyrkia, der 12 syriske flyktninger hadde druknet på vei over Middelhavet til Kos den 2. september 2015. Bildet og historien fikk viral spredning. Etter bare ett døgn ble det delt 53 ooo ganger i timen på Twitter verden over (D’Orazio, 2015), og emneknaggen \#refugeeswelcome ble raskt en av de mest brukte på Twitter. Medieoppmerksomheten og 
flyktningengasjementet spredde seg også raskt internt i mange land etter hvert som flyktningstrømmene nådde de europeiske lands grenser. I Tyskland fikk sosiale medier og emneknaggen \#Merkelschweigt («Merkel er stille») stor innflytelse på oppmerksomheten og handlingsrommet til politikerne i forbindelse med situasjonen, og Tyskland ble også det landet som først og i størst grad åpnet grensene for flyktningene i Europa (Economist, 2015).

Flyktningstrømmen nådde også Norge. I løpet av 2015 kom rundt 31000 flyktninger for å søke asyl i Norge, en relativt liten andel av alle flyktningene totalt i Europa, men et svært høyt antall relativt til innbyggertallet i Norge. ${ }^{1}$ Tilstrømningen skjedde også på så kort tid at det skapte store utfordringer for det offentlige mottaksapparatet, som raskt ble overbelastet. Flyktninger måtte overnatte ute i søknadskø uten tilgang til mat eller sanitære fasiliteter. Medieoppmerksomheten og debatten rundt situasjonen vokste, og ulike typer sivilsamfunnsaktører trådte til for å avhjelpe situasjonen. Frivillige i Oslo tok raskt initiativ til utdeling av mat, klær og utstyr for å hjelpe flyktningene. På kort tid fikk denne situasjonen preg av et massivt ad hoc frivillig engasjement som bredte seg over hele Norge ved hjelp av sosiale medier. Mange nye hjelpegrupper og initiativ dukket opp, og hjelpebidrag ble i stor grad mobilisert og organisert gjennom Facebook-grupper. Som vi skal se i flere av kapitlene i denne boken, illustrerer dette engasjementet i kjølvannet av flyktningsituasjonen hvordan nordmenn kan utøve samfunnsengasjement og delta i kollektive handlinger i dag, og hvordan globalisering, individualisering og digitalisering på ulike måter påvirker måtene vi mobiliseres og organiserer oss til kollektivt engasjement på. I boken undersøker vi videre hvordan globalisering gjennom klimaspørsmål og klima-engasjement påvirker måtene vi engasjerer oss og skaper fellesskap på, vi ser på i hvilken grad digitaliseringen har forandret våre mønstre for kollektiv handling, samt hvordan individualiseringstendenser har endret vårt forhold til organisering av kollektiv handling.

1 Se https://ec.europa.eu/eurostat/documents/2995521/7203832/3-04032016-AP-EN.pdf/79oebao1381c-4163-bcd2-a54959b99ed6 
Et sentralt mål for boken er å gi utfyllende eksempler på hvordan samfunnsengasjement og kollektiv handling tar form i Norge i dag, og å kritisk diskutere i hvilken grad disse representerer noe nytt i måtene vi engasjerer og organiserer oss i kollektive handlinger på, og i hvilken grad de kan ses som direkte resultater av digitaliserings-, individualiseringsog globaliseringsprosessene. Som vi skal diskutere nærmere nedenfor, omfattes disse problemstillingene av et hovedspørsmål for boken: I hvilken grad ser vi fremveksten av en ny form for kollektiv handling i Norgekonnektiv handling? Før vi tar for oss dette begrepet og spørsmålet, vil vi først diskutere noen av de forutsetningene som må være til stede for at samfunnsengasjement og kollektiv handling kan finne sted.

\section{Hva forutsetter samfunnsengasjement og kollektiv handling?}

Når vi skal undersøke nye former for samfunnsengasjement og kollektiv handling, kan vi begynne med en diskusjon om hvilke forutsetninger som må være til stede for at kollektiv handling i det hele tatt skal kunne skje. Her kan vi også skille mellom betingelser på ulike nivå, for eksempel betingelser knyttet til individer og organisasjoner, betingelser knyttet til teknologi og kultur, og betingelser knyttet til samfunns- og demokratikontekst.

På individnivå er det vanlig å se samfunnsengasjement som bestående av to deler: politisk engasjement og frivillig engasjement. Mens politisk engasjement betegner det som er rettet mot politiske institusjoner, prosesser og avgjørelser, er frivillig engasjement rettet mer mot ulike interesser, mål og forhold i samfunnet, det vil si mot andre mennesker og grupper. Disse to formene for samfunnsengasjement innebærer som regel deltakelse i kollektive handlinger rettet mot samfunnsspørsmål og krever noen former for organisering. Kollektiv handling er altså aktiviteter foretatt av medborgere med formål om å bidra til et kollektivt gode, det vil si aktiviteter som genererer gevinster som ikke kan selges på et marked til private kjøpere, og som gir nytte til et fellesskap.

En sentral problemstilling knyttet til kollektiv handling er å forklare hvorfor individer bruker tid, penger og sine evner for å fremme kollektive 
mål eller goder. Fra et instrumentelt og økonomisk rasjonelt perspektiv med fokus på kostnader og gevinster av kollektiv handling vil individers deltakelse i kollektive handlinger bare være fornuftig hvis gevinstene er større enn kostnadene. Ifølge Olson (1965) vil rasjonelle individer oppføre seg som gratispassasjerer og dermed ikke bidra i kollektive handlinger hvis utfallet av en kollektiv handling er et kollektivt gode som alle vil kunne nyte godt av, uavhengig av den enkeltes innsats. Tradisjonelt har samfunnsengasjement vært knyttet til frivillig organisering, og som vi har vært inne på, krever slik kollektiv handling koordinering og organisering, like mye om det dreier seg om politisk aktivisme rettet mot politikk og samfunnsendring eller om handlinger rettet mot å løse kollektive problemer i form av frivillig innsats.

Behovet for formelle organisasjoner er derfor et sentralt vilkår for kollektiv handling og knyttes som regel til problemet med «gratispassasjerer», som oppstår når flere individer samarbeider for å produsere et kollektivt gode (Olson, 1965). Individer vil delta i kollektive handlinger hvis de blir tilbudt selektive insentiver, det vil si gevinster som er tilgjengelige bare for dem som gjør en innsats. Mens Olson bare fokuserte på materielle insentiver som fysiske goder, har Clark og Wilson (1961) påpekt at selektive insentiver også kan være solidariske insentiver knyttet til tilhørighet i en gruppe, eller målbaserte insentiver knyttet til oppnåelse av meningsfulle mål. Individer kan for eksempel velge å være med i kollektive handlinger fordi de får igjen en økt selvfølelse eller opplevelse av fellesskap og tilhørighet. Likevel er de største hindringene for kollektiv handling knyttet til kommunikasjons- og koordineringsutfordringer. Formelle organisasjoner, og særlig frivillige organisasjoner, spiller dermed en sentral rolle for koordinering og organisering av ulike former for kollektive handlinger. McCarthy og Zald (1977) har her understreket at deltakelse i ulike former for kollektiv handling ikke bare er betinget av individuell motivasjon, men også påvirket av organisatoriske arrangementer og sosiale nettverk. Individer er delaktige i sosiale grupper og nettverk og i sivilsamfunnsorganisasjoner og deltar i kollektive handlinger som en følge av sin tilhørighet i slike sosiale sammenslutninger.

På samfunnsnivå vil type eller grad av demokrati være en sentral forutsetning for kollektiv handling og engasjement. Et velfungerende 
demokrati forutsetter først og fremst formelle demokratiske institusjoner som universell stemmerett, politiske partier og valgt parlament. Samtidig vil også et sivilsamfunn som opprettholder en kultur for medborgeres aktive deltakelse og engasjement, være en sentral forutsetning (Almond \& Verba, 1963; Alexander, 2006). Sivilsamfunnet kan ses på som den samfunnssfæren der samfunnsengasjement, kollektiv handling og offentlig kommunikasjon normalt foregår, et sted mellom den statlige sfæren, den private sfæren og den kommersielle sfæren. I et velfungerende sivilsamfunn vil det kunne foregå en dynamisk og responsiv offentlig diskurs omkring ulike interesser, mellom myndigheter, medborgere og kommersielle aktører (Janoski, 1998).

I sivilsamfunnet kan mennesker tre ut fra sine privatsfærer og komme sammen av fri vilje som samfunnsborgere, i en innsats enten for felles interesser eller for snevrere gruppeinteresser. Siden slikt samfunnsengasjement og kollektiv handling gjerne krever en viss infrastruktur for å komme til uttrykk, så har fokuset gjerne vært på den funksjonen og de rollene som ulike typer av frivillige organisasjoner og sammenslutninger har. Det er gjennom slike sammenslutninger og organisasjoner at kollektiv handling og interesser har blitt organisert og kommet til uttrykk. Frivillige organisasjoner og det større organisasjonssamfunnet blir derfor sett på som et helt sentralt grunnlag i sivilsamfunnet og som en infrastruktur for kollektiv handling og samfunnsengasjement, ikke minst i Norge, der frivillighet og frivillige organisasjoner står sterkt. Samtidig kan sivilsamfunnet også ses på som rommet for offentlig kommunikasjon og samfunnsdialog. Dette kan være offentlige møter, demonstrasjoner og kafé-diskusjoner, og ikke minst den kommunikasjonen som skjer gjennom mediene, der særlig massemedier som radio, tv og aviser og nå også sosiale medier spiller sentrale roller som arenaer for offentlig samfunnsdebatt. Ideelt sett vil disse mediene utgjøre et offentlig rom der medborgere kan debattere og diskutere allmenne samfunnsspørsmål og interesser, og der offentligheten kan videreformidle disse spørsmålene og interessene fra sivilsamfunnet til det formelle politiske systemet.

Viktige forutsetninger for et slikt vitalt offentlig rom handler for eksempel om tilgang til disse arenaene, hvilke aktører som deltar i samfunnsdebatten, og om kvaliteter og kjennetegn ved de ulike kanalene og 
arenaene. Her har for eksempel ny kommunikasjonsteknologi og sosiale medier skapt nye kanaler og arenaer for kommunikasjon, samtidig som de har skapt nye måter å handle og samhandle på. Internett og sosiale medier har på denne måten skapt en ny infrastruktur og nye verktøy for mobilisering og organisering av kollektiv handling, noe som kan ha endret på den betydning som organisasjoner kan ha for kollektiv handling i dag (Bimber mfl., 2005). Som et resultat av digitale kommunikasjonsnettverk er kommunikasjon blitt mindre kostbart, mindre tidkrevende og ubegrenset av tid og rom. Digitale kommunikasjonsnettverk har dermed endret vilkårene for kollektiv handling, både når det gjelder gruppestørrelse og formelle organisasjonsroller. Ifølge Olson (1965) er små grupper bedre egnet til å handle kollektivt enn store grupper fordi kommunikasjon og mobilisering er lettere når størrelsen på gruppen er begrenset. Men digitale kommunikasjonsnettverk gjør det nå mulig å kostnadsfritt nå ut til et stort antall individer uten begrensninger i tid og rom. Kollektiv handling er også avhengig, ifølge Olson (1965), av formelle organisasjoner for å motivere og koordinere deltakere i en kollektiv handling. Her har digitale kommunikasjonsnettverk muliggjort koordinering gjennom løst koblede nettverk uten sentrale strukturer for lederskap, beslutningstaking og rekruttering, noe som kan utfordre argumentet om at kollektiv handling er avhengig av organisasjoner.

Digitale kommunikasjonsnettverk kan derfor sies å ha bidratt til å endre kollektive handlingsformer i minst to retninger (Earl mfl., 2015). For det første har digitale kommunikasjonsnettverk åpnet muligheten for kortvarig og kortlevd engasjement i kollektive handlinger gjennom for eksempel online opprop, e-postkampanjer og andre former for digitale aksjoner. Dette har gjort det mulig for etablerte sosiale bevegelser og frivillige organisasjoner å mobilisere og engasjere brede lag av befolkningen for en sak og ikke bare de meste engasjerte aktivistene og frivillige. For det andre har digitale kommunikasjonsnettverk åpnet muligheten for organisering og koordinering utenfor tradisjonelle formelle organisasjoner samtidig som tradisjonelle organisasjoner tilpasser seg samhandlingsformer muliggjort av digitale kommunikasjonsnettverk. Gjennom digitale kommunikasjonsnettverk og særlig sosiale medier kan 
initiativtakere utenfor etablerte organisasjoner og bevegelser mobilisere og engasjere individer og grupper til handling for ulike saker eller protestaksjoner. Dette gir mulighet til organisering utenfor formelle organisasjoner. Samtidig vil digitale kommunikasjonsnettverk kunne påvirke måten etablerte formelle sivilsamfunnsorganisasjoner drives på (Bimber mfl., 2012; Wells, 2015). Interne relasjoner i organisasjoner kan bli endret i retning av mindre byråkrati og sentralisert styring. Personlige, tillitsbaserte interaksjoner, personlig engasjement og gründerånd kan bli viktigere som elementer for å støtte opp under kollektive handlinger. Eksterne relasjoner med organisasjonens omgivelser kan også bli påvirket av at organisatoriske grenser blir løsere, og at det blir lettere for medlemmer og ikke-medlemmer i organisasjonen å krysse disse grensene. Dette kan føre til at organisasjonsmedlemskap blir mindre viktig for dem som deltar i ulike kollektive handlinger, samtidig som mobilisering for kollektive handlinger kan nå bredere ut og til flere enn organisasjonens egne medlemmer.

Samtidig som en økende mengde litteratur og empiriske eksempler viser oss de transformerende kreftene som ligger i digital teknologi på blant annet samfunnsengasjement og kollektiv handling, vil det fra mer konstruktivistiske perspektiver på teknologiens sosiale effekter kunne argumenteres for mer moderate og sosialt modererte effekter av digitale medier. (Mackenzie \& Wajcman, 1999; Sassen, 2002; Westrum, 1991; Orlikowski; 1992). Et generelt perspektiv her er at forholdet mellom (digital) teknologi og samfunn er komplekst og verken deterministisk, ubetydelig eller vilkårlig. Teknologi og samfunn påvirker hverandre og er gjensidig konstituerende. I et slikt perspektiv vil den digitale teknologien i like stor grad kunne forventes å måtte tilpasses eksisterende mobiliseringsog organisasjonsformer, som at den digitale teknologien forandrer de eksisterende formene for samfunnsengasjement og kollektiv handling. Tidligere studier i Norge har for eksempel vist at generell bruk av internett i lokale frivillige organisasjoner er utbredt men at bruken av sosiale medier har vært begrenset (Eimhjellen, 2014, Eimhjellen et al, 2014). Både lokale og nasjonale organisasjoner bruker internett mest som et administrativt verktøyogsomen enveisinformasjonskanalut, menstoveis-kommunikasjon med medlemmer og omverdenen er mindre vanlig (Arnesen, Sivesind og 
Gulbrandsen, 2016; Eimhjellen et al., 2014, Eimhjellen, 2014). Samtidig som organisasjoners bruk av internett har vist seg å ha sammenheng med en sentralisering av avgjørelsesmakt i organisasjoner har også nettbruken vært positivt knyttet til organisasjonsvitalitet (Eimhjellen, 2014). Gjennom flere kapitler i boken, spesielt i kapittel 3 og 4, vil vi undersøke digitaliseringens påvirkning på nordmenns samfunnsengasjement og deltakelse i kollektiv handling. Et overordnet spørsmål er her i hvilken grad digital teknologi har endret på de grunnleggende handlings- og organiseringsformene i det norske sivilsamfunnet.

\section{Fra kollektiv til konnektiv handling?}

Med dette bakteppet skal vi altså i denne boken undersøke i hvilken grad samfunnsendringsprosesser som digitalisering, individualisering og globalisering har ført til fremveksten av en ny form for kollektiv handling i Norge: konnektiv handling. Ifølge Bennett og Segerberg (2012, 2013) har sosiale og kulturelle endringer knyttet til globalisering og individualisering ført til svekkede gruppemedlemskap og lojaliteter. Det har også ført til mer individualiserte former for samfunnsengasjement, som i større grad er orientert mot å uttrykke personlig livsstil og identitet. Samfunnsengasjementet er mer personliggjort, i den forstand at det ikke er basert på medlemskap i eller identifisering med sosiale grupper og ideologier, men er tuftet på personlig uttrykk. Ifølge Bennet og Segerberg (2012, 2013) oppstår det også muligheter for desentraliserte og selvorganiserte former for kollektiv handling når kommunikasjon i økende grad foregår gjennom desentraliserte digitale nettverk. Digitale nettverk utgjør nå mediet og infrastrukturen som muliggjør konnektiv handling, samtidig som individualiseringen bidrar med en endret kulturell motivasjon og orientering - den personlige handlingsrammen - for denne formen for handling.

Det som kjennetegner disse nettverkene, er at de kan operere gjennom sosiale medier uten sterk organisatorisk kontroll eller konstruksjon av et symbolsk fellesskap, kontrastert med tradisjonelle former for kollektiv handling som krever formelle organisasjoner. Dermed er det mulig å skille, ifølge Bennett og Segerberg (2012, 2013), mellom to kollektive 
handlingslogikker: 1) den klassiske kollektive handlingslogikken, artikulert av Olson (1965) og aktualisert av sosiale bevegelser-teoretikere (Mellucci, 1996; McAdam, 2001) som har understreket betydningen av kultur, identitet, følelser, sosiale nettverk og mulighetsstrukturer som faktorer som påvirker deltakelse i kollektive handlinger, men som også forutsetter organisasjonsbaserte medlemskap, identiteter og koordineringsmekanismer, 2) og den konnektive handlingslogikken, som er organisert på andre prinsipper. Konnektiv handling oppstår som et resultat av bruk av digitale medier, handlingsmulighetene (affordances) i de digitale mediene, og av de kulturelle endringene knyttet til individualisering.

Konnektiv handling er mer individualisert og koordinert gjennom teknologiske prosesser uten behov for kollektiv identitet eller formell organisering. Innenfor den konnektive handlingslogikken er deltakelse i offentligheten eller bidrag til et kollektivt gode en personlig handling, en form for selv-initiert anerkjennelse eller selvvalidering. Kommunikasjon gjennom digitale nettverk blir den grunnleggende formen for organisering og erstatter hierarkiske strukturer og profesjonelle ledere. Dette perspektivet har vært omformulert, men med det samme grunnleggende skillet mellom det gamle og det nye, av Zuckerman (2014), som identifiserer nye former for samfunnsengasjement som et resultat av "postrepresentative demokrati» og veksten av «deltakende medier».

I resten av dette innledende kapitlet gir vi en oversikt over de sentrale problemstillingene som de enkelte kapitlene i boken undersøker, samt en kort redegjørelse for hvordan de relevante kapitlene belyser problemstillingene.

\section{Bokens sentrale problemstillinger}

\section{Digitaliseringens konsekvenser for samfunnsengasjement}

Digitalisering og spesielt utbredelsen av sosiale medier kan tenkes å medføre en demokratisering av samfunnsengasjement, i den forstand at flere vil kunne engasjere seg. Ved å gjøre tilgang til informasjon lettere og mindre ressurskrevende og ved å åpne for ulike digitalbaserte 
interaksjonsformer, kan sosiale medier utvide mulighetsrommet for engasjement, øke motivasjon for samfunnsengasjement og bidra til å engasjere nye segmenter av befolkningen som tidligere ikke har vært samfunnsengasjerte. Alternativt kan sosiale medier tenkes å forsterke de eksisterende ulikhetene som kjennetegner samfunnsengasjement ved at de som er mest engasjert fra før, også er de som benytter de nye mulighetene som sosiale medier tilbyr for å koordinere kollektive handlinger og delta i samfunnsdebatten. Hvilke av disse hypotesene - mobiliseringshypotesen eller forsterkningshypotesen (Norris, 2001) - som er riktig, er et empirisk spørsmål.

I kapittel 3 undersøker Ivar Eimhjellen og Jørn Ljunggren i hvilken grad sosiale medier bidrar til en demokratisering av samfunnsengasjement $\mathrm{i}$ den forstand at online deltakelse er mindre preget av ulikheter med hensyn til kjønn, alder, bosted og utdanning. De undersøker flere former for samfunnsengasjement online: offentlig kommunikasjon (med f.eks. politikere, journalister, offentlige personer), politisk interessestimulans, medlemskap i Facebook-grupper knyttet til institusjonell politikk eller protestpolitikk, meningsytring i sosiale medier, og digitalt frivillig arbeid. Resultatene viser et komplekst landskap der ulike typer bakgrunnsfaktorer spiller ulike roller for ulike typer online aktiviteter. Sosiale medier ser ut til i større grad å mobilisere yngre folk for de fleste typer aktiviteter, med unntak av politisk meningsytring. Likevel spiller utdanningsnivået en betydelig rolle for å forklare hvem som er aktiv online for de fleste aktivitetene, med unntak av politisk gruppemedlemskap på Facebook. I tillegg preger kjønnsulikheter (i den forstand at menn deltar mer enn kvinner) både politisk meningsytring og politisk Facebook-gruppemedlemskap. Sosiale mediers demokratiseringspotensial ser dermed ut til å være begrenset der graden av online engasjement, på samme måte som ved offline engasjement, er sterkt korrelert med utdanningsnivå.

Et annet viktig spørsmål knyttet til effekten av digitale kommunikasjonsnettverk er forholdet mellom online og offline former for samfunnsengasjement. På den ene siden kan online og offline handlinger være to forskjellige former for aktiviteter med liten grad av overlapp. I så tilfelle vil digital kollektiv handling potensielt kunne mobilisere personer som er svært forskjellige fra de som engasjerer seg i organisasjoner. På den andre 
siden kan disse to formene for engasjement faktisk konkurrere, og digitalt engasjement kan potensielt svekke og fortrenge tradisjonell kollektiv handling. I så tilfelle vil personer som tidligere har vært engasjert offline, og som engasjerer seg online, kunne bli mindre engasjert i organisasjonslivet. Et tredje alternativ er at de to engasjementsformene er uavhengige av hverandre, enten fordi de komplementerer hverandre, eller fordi de foregår hver for seg. I dette tilfellet vil de samme personene kunne være engasjert både online og offline.

Bernard Enjolras, Kari Steen-Johnsen og Audun Beyer har i kapittel 4 undersøkt forholdet mellom online og offline engasjement med data fra tre runder av en web-basert spørreundersøkelse utført i Norge i 2012, $2014 \mathrm{og} 2016$ om ulike former for frivillig medlemskap og frivillig innsats over tid. Forskerne finner her støtte for mobiliseringshypotesen om at online aktivitet fører til offline aktivitet - når det gjelder medlemskap i frivillige organisasjoner. Det å følge en Facebook-gruppe knyttet til frivillige organisasjoner og protestgrupper har en effekt på offline organisasjonsmedlemskap, men ikke på frivillig arbeid. Et viktig unntak er likevel at det å følge en Facebook-gruppe knyttet til en frivillig organisasjon har en positiv effekt på frivillig arbeid.

I kapittel 7 har Ivar Eimhjellen gjort en kvantitativ studie av engasjementet rundt flyktningsituasjonen slik det ble uttrykt i sosiale og tradisjonelle medier og gjennom frivillige organisasjoner. Eimhjellen finner at sosiale medier, med Facebook i spissen, utgjorde en egen infrastruktur for mobilisering og organisering av frivillig hjelp og bistand under flyktningsituasjonen. Likevel hadde konkrete hjelpebidrag gjennom sosiale medier et begrenset omfang sammenlignet med hjelpebidrag gjennom tradisjonelle frivillige organisasjoner. I tillegg var også etablerte mediekanaler viktigere for spredning av informasjon om hvordan man kunne bidra som frivillig, enn det de sosiale mediene var. Funnene taler for et argument om at sosiale medier har en supplerende funksjon som infrastruktur for mobilisering og organisering av frivillig hjelp og bistand. Etablerte organisasjonsstrukturer og mediekanaler er fortsatt sentrale som infrastruktur for mobilisering og organisering av samfunnsengasjement og kollektiv handling, samtidig som sosiale medier bidrar til mer mangfold, responsivitet og fleksibilitet i norsk samfunnsengasjement. 
Med bakgrunn i en studie av nasjonale frivillige organisasjoner har Audun Beyer og Kari Steen-Johnsen i kapittel 9 undersøkt skillelinjer i måten nasjonale frivillige organisasjoner har tatt i bruk nye digitale medier på, og hvorvidt digitaliseringen muliggjør nye organisasjonsformer, nye måter å engasjere medlemmer og frivillige på og nye muligheter for utadrettet virksomhet. Funnene viser at internett og sosiale medier gjennomsyrer alle typer av organisasjoner i Norge, men at det finnes viktige forskjeller mellom ulike organisasjoner. Videre identifiseres ulike dimensjoner når det gjelder hva sosiale medier brukes til, med klare skiller mellom aktivitet rettet mot offentligheten på den ene siden, og aktivitet rettet mot medlemmer på den andre. Til slutt finner forfatterne at det først og fremst er mangel på ressurser som er årsak til at en tredjedel av organisasjonene velger å ikke bruke sosiale medier.

\section{Skiller mellom frivillighet og politisk aktivisme}

Som vi har vært inne på, er det i faglitteraturen vanlig å skille mellom to former for samfunnsengasjement: frivillig innsats og politisk aktivisme (Eliasoph, 2013). Disse to formene for samfunnsengasjement gjenspeiler også ulike former for kollektive handlinger og ulike kulturelle rolleforståelser. Mens frivillige forsøker å løse samfunnsproblemer gjennom konkrete handlinger, tar politiske aktivister sikte på å adressere problemenes røtter ved å oppnå samfunnsendringer gjennom politiske prosesser. En slik selvforståelse innen frivilligheten er med på å begrense frivilliges deltakelse i offentligheten og forsterker avideologiseringen av storparten av den frivillige sektoren. Det er viktig å understreke at dette skillet mellom frivillig innsats og politisk aktivisme er relativt nytt og oppsto i kjølvannet av de tradisjonelle sosiale bevegelsenes avideologisering utover på 1960-tallet. De tradisjonelle sosiale bevegelsene har dannet grunnlaget for den norske frivillige sektoren og var tuftet på bestemte ideologier (Sivesind, mfl., 2002). Innen disse sosiale bevegelsene var politisk aktivisme og frivillig innsats ikke atskilt, men to sider av samme sak. Med svekkelsen av de sosiale bevegelsenes ideologiske grunnlag, som følge av $ø$ kende individualisering, svekkede klasse-, religiøse, og regionale identiteter, og utvikling av forbrukskultur, ble samfunnsengasjement i disse 
bevegelsene og i nyere frivillige organisasjoner gradvis løsrevet fra den ideologiske dimensjonen. Resultatet ble en økende spesialisering mellom de to formene for kollektiv handling.

Samtidig har moderniseringsprosesser ført til en utvidelse av det som kan betegnes som «politisk» (Beck, 1992). Mens «det politiske» tradisjonelt var det som ble behandlet av det politiske systemet, lar nyere samfunnsutfordringer seg ikke løse av det politiske systemet alene, noe som har ført til en "politisering av samfunnet» eller utvikling av det som er blitt betegnet som det sub-politiske (Beck, 1992). Nyere former for kollektiv handling er ikke nødvendigvis eksklusivt rettet mot det politiske systemet og mot politiske endringer, men forsøker å løse samfunnsutfordringer gjennom konkrete handlinger. Disse konkrete handlingene har en politisk betydning ved at de er innskrevet i et politisk landskap og en politisk forståelsesramme. For eksempel: En frivillig organisasjon som utvikler løsninger for fornybar energi, og som mobiliserer frivillig innsats til dette formålet, bidrar til å løse klimautfordringer samtidig som den er posisjonert og har en politisk mening innenfor det klima-politiske feltet. Med andre ord kan endringstrender som fører til en politisering av samfunnsspørsmål, potensielt føre til en utvisking av skillet mellom frivillig innsats og politisk aktivisme og til utvikling av nye former for sammenbinding mellom politisk aktivisme og frivillig innsats. I eksempelet med innsamlingsaksjonen til Leger uten grenser, som dette kapitlet startet med, viser tall fra Norsk Medborgerpanel at politisk ståsted var en hovedforklaring på hvem som bidro i aksjonen, og en viktig motivasjonsfaktor for å bidra blant de som donerte penger. De frivillige pengebidragene som over 80 ooo mennesker gav til en ikke-politisk humanitær organisasjon, var på denne måten i svært stor grad uttrykk for politisk ståsted og holdning.

Kristin Strømsnes og Steinar Gjerde ser i kapittel 2 nærmere på organisasjoners medvirkning i politiske aksjoner i Norge ved å undersøke data på aksjoner som er søkt gjennomført fremfor Stortinget og medieomtaler av aksjoner i Norge over tid. De finner mellom annet at frivillige organisasjoner er tettere koblet til politiske aksjoner enn hva mye av faglitteraturen gir inntrykk av er vanlig. Bare en begrenset del av det som foregår innenfor aksjonskanalen fremstår som uorganisert og spontant. 
Organisasjoners ressurser knyttet til planlegging, tilrettelegging, og gjennomføring av aksjoner ser ut til å være en svært viktig del av aksjonskanalen i Norge. I kapittel 5 går Audun Fladmoe også dypere inn i hvordan politisk aktivisme og frivillig innsats bindes sammen i Norge. Han undersøker frivillige bidrag i flyktningsituasjonen i 2015 og viser blant annet at bidrag i flyktningsituasjonen åpenbart hadde en partipolitisk profil, både blant dem som bidro for tradisjonelle organisasjoner og blant dem som bidro for nye initiativ. Frivillig innsats knyttet til flyktningsituasjonen gjenspeilte en motivasjon for å bidra til å løse en humanitær krise, men var også for mange av de involverte en politisk handling i en politisk kontekst preget av en restriktiv immigrasjonspolitikk. Dette er også tema som Synne Sætrang er inne på i sin nærstudie av Refugees Welcome-nettverket under flyktningsituasjonen 2015. Tendensen til utvisking av skillet mellom politisk engasjement og frivillig innsats kjennetegner også initiativet «Bærekraftige liv», som Ivar Eimhjellen analyserer i dybden i kapittel 8. Initiativet har sitt utspring i et engasjement for å løse klimaspørsmål og å skape gode lokalsamfunn. Initiativet er del av en internasjonal sosial bevegelse som fremmer lokal konkret handling for å bedre klimaet, og som en måte å påvirke klimapolitikken på. Initiativet har også utviklet seg fra å være en grasrots- og hverdagsbasert bevegelse til også å bli en interesseorganisasjon innenfor klimapolitikk på nasjonalt nivå, samtidig som de fortsatt er forankret i frivillig deltakelse rettet mot konkrete endringer på lokalplan.

\section{Nye organisasjonsformer}

Medlemsbaserte frivillige organisasjoner på lokalt, nasjonalt og overnasjonalt nivå er i endring blant annet under påvirkning av digitale kommunikasjonsteknologier, der vertikal-hierarkiske organisasjoner i $ø$ kende grad tar i bruk nettverk som koordineringsform (Podolny \& Page, 1998). Som Castells skriver (2004, s. 5): «nettverk ble den mest effektive organisasjonsform som et resultat av tre viktige funksjoner i nettverk som dro nytte av de nye teknologiske omgivelsene: fleksibilitet, skalerbarhet og overlevelsesevne». Konsekvensen av denne utviklingen er at en ny organisasjonsform - som inkluderer kjennetegn fra både hierarkiske 
og «heterarkiske» (nettverksbasert) (Kontopoulos, 1993) organisasjonsformer - er i utvikling. Denne nye organisasjonsformen, som består av en kombinasjon av desentraliserte, fleksible, lokale og globale medlemsnettverk og hierarkisk vertikal styring, og som muliggjør koordinering og meningsdannelse, diskusjoner og aktiviteter på tvers av nivåer, ser ut til å spre seg blant medlemsbaserte frivillige organisasjoner. Nye organisasjonsformer, som blander hierarkisk styring og desentralisert nettverkskoordinering, oppstår også som en følge av individualisering av samfunnsengasjement som påvirker organisasjonenes struktur og virkemåter. En grunn til dette er at det individualiserte samfunnsengasjementet er konstruert gjennom dens institusjonalisering (Hustinx, 2010), og organisasjoner spiller en avgjørende rolle i denne sammenhengen.

Med utgangspunkt i nettverket Refugees Welcome (RW), som oppstod som et sosiale medier-basert initiativ høsten 2015, viser Synne Sætrang i kapittel 6 hvordan digitale kommunikasjonsnettverk dannet infrastrukturen for den omfattende mobiliseringen av frivillig engasjement. RWnettverket startet som et initiativ på Facebook, som samlet utstyr for å dekke flykningenes grunnleggende behov og vokste raskt ved at lokale initiativ dukket opp over hele landet i løpet av en kort periode og mobiliserte rundt 80 ooo medlemmer i 61 lokale grupper som satte i gang aktiviteter både online og offline. Digitale kommunikasjonsnettverk fungerte som et effektivt verktøy for å mobilisere, dele informasjon og koordinere lokale frivillige aktiviteter. Etter akuttfasen presset likevel spørsmål om organisering og formalisering av bevegelsen seg mer på, samtidig som de lokale initiativene engasjerte seg i integreringsarbeid og utviklet samarbeidsrelasjoner med frivillige og offentlige aktører innenfor flyktningfeltet. Studien viser at internettbaserte initiativer har evne til å mobilisere raskt og i stor skala. Samtidig vil bærekraften til slike initiativer forutsette noen former for formell organisering og institusjonalisering. RW fremstår i dag som en organisasjon som delvis består av sosiale medier-baserte grupper og uformelle offline nettverk, og delvis som en formell hierarkisk organisasjon.

Også initiativet «Bærekraftig Liv», som er analysert av i kapittel 8, ble startet som et nettverk som var lokalt forankret, uformelt og fleksibelt. På tross av «organisasjonsangst» har initiativtakerne som resultat av nettverkets vekst og suksess vært nødt til å formalisere organisasjonen 
og introdusere en viss hierarkisk styring i nettverkene. Bærekraftig Liv fremstår som en kompleks og multifunksjonell organisasjon, med flere organisatoriske nivåer koblet sammen i nettverk, en hybrid koordineringsform preget av både nettverk og hierarki og der også digitale kommunikasjonsnettverk spiller en viss rolle.

\section{Transnasjonal kollektiv handling}

Globalisering kan betegnes som to ulike dynamikker (Sassen, 2007). På den ene siden betegner begrepet dannelsen av overnasjonale institusjoner, mens det på den andre siden fanger inn territorielle prosesser på lokalt eller nasjonalt nivå, som involverer grenseoverskridende nettverk som kobler sammen aktører fra ulike nasjonale og undernasjonale lokaliteter eller territorier. Digitale kommunikasjonsnettverk har bidratt til en rivende utvikling av globalisering forstått som sammenkobling av ulike lokaliteter eller territorier gjennom nettverk som overskrider territorielle grenser.

Digitale kommunikasjonsnettverk har for eksempel åpnet muligheten for lokale sivilsamfunnsaktører til å både delta i det globale sivilsamfunnet og påvirke globale institusjoner, som er tilfellet når for eksempel norske miljøorganisasjoner deltar i FNs klimatoppmøte. Digitale kommunikasjonsnettverk gjør det også mulig for lokale sivilsamfunnsaktører å være delaktige i overnasjonale sivilsamfunnsnettverk, til å drive mikro-former for kollektivt engasjement lokalt som en del av en transnasjonal eller global bevegelse.

Både Refugees Welcome (kapittel 6) og Bærekraftig Liv (kapittel 7) er eksempler på territorielle initiativer, som er forankret lokalt, har nasjonal rekkevidde og er delaktige i transnasjonale nettverk. Nye flyktninginitiativer har oppstått over hele Europa i forbindelse med flyktningsituasjonen og har også dannet et overnasjonalt nettverk: Refugees Welcome International (http://www.refugees-welcome.net). På den samme måten er Bærekraftige liv-initiativet delaktig i den globale bevegelsen Transition Network (https://transitionnetwork.org), som har som formål å endre verden i en mer bærekraftig retning gjennom lokale initiativer. Begge casene illustrerer hvordan kollektive sivilsamfunnsinitiativer overskrider territorielle grenser og oppnår, gjennom transnasjonale nettverk, en global effekt ved å handle lokalt. 
Disse grenseoverskridende nettverkene har implikasjoner for lokalisering av økonomiske aktiviteter, dannelse av globale arbeidsmarkeder som påvirker migrasjonsstrømmer, som i sin tur bidrar til å forsterke disse transnasjonale nettverkene. Migranter som har «føtter i to samfunn», handler og utvikler ofte identiteter innenfor relasjonelle nettverk som kobler to eller flere nasjonalstater. Transnasjonale migranter organiserer seg ofte i transnasjonale nettverk som kan danne grunnlaget for formelle organisasjoner i ulike diasporaland. Organisering på tvers av grenser og relasjoner med hjemlandsinstitusjoner, sivilsamfunnsorganisasjoner og myndigheter bidrar også i å organisere transnasjonale migranter (Ebaugh \& Chafetz, 2002).

I kapittel 10 undersøker Guro Ødegård og Marianne Takle hvilken betydning individers tokulturelle bakgrunn har for utviklingen av fellesskap og tilhørighet gjennom frivillige organisasjoner. Her ser de på den betydningen transnasjonale organisasjoner for barn og unge med innvandrerbakgrunn har for sosial og politisk integrasjon, og hvordan slike organisasjoner utvikles i møte med den norske tradisjonen for frivillig organisering. Et gjennomgående trekk er at migrantorganisasjonenes sosiokulturelle og politiske dimensjoner er nær knyttet sammen. Organisasjonene ser ut til å innta viktige funksjoner som sosiale og politiske integrasjonsarenaer, der fokus på integrasjon i Norge blir balansert med en orientering mot de transnasjonale båndene som organisasjonene er bærere av. Informantene i studien beskriver organisasjonenes rolle som arena for kulturell opprettholdelse som en forutsetning for vellykket integrasjon og deltakelse i majoritetssamfunnet blant mange unge med minoritetsbakgrunn. De organisasjonene som har transnasjonale bånd og utøver transnasjonale praksiser, ser her ut til å være de som i størst grad også orienterer seg mot norsk nettverksbygging og fremhever sin egen rolle som integrasjonsarena for sine medlemmer inn mot det norske majoritetssamfunnet.

\section{Nye former for kollektiv handling i Norge?}

Som vi har vært inne på, er det overordnede spørsmålet i boken om hvorvidt samfunnsendringsprosesser som digitalisering, individualisering og globalisering har ført til fremveksten av en ny kollektiv handlingsform i Norge: konnektiv handling. Her har vi blant annet studert 
digitaliseringens konsekvenser for tradisjonelt offline engasjement, for sosial ulikhet i nye deltakelsesformer og for etablerte organisasjoner. Vi har undersøkt utviklingen i forholdet mellom frivillig og politisk deltakelse i dag, og vi har sett på fremveksten av nye frivillige og politiske nettverk og organisasjoner. Vi har også belyst hvordan globalisering i ulike fasetter påvirker måten nordmenn engasjerer seg i kollektive handlinger på i dag.

Fremveksten av digitale medier har lenge vært fulgt av påstander om større omveltninger i hvordan mennesker vil kommunisere, mobilisere og organisere kollektiv handling og samfunnsengasjement. Det er nok få i dag som vil benekte at digitale medier har hatt innvirkning på hvordan vi kommuniserer med hverandre, engasjerer oss og organiserer kollektiv handling. Likevel mener vi det er en feilslutning at teknologien har endret på de grunnleggende logikkene og forutsetningene for kollektiv handling i Norge. Som Wells (2014) påpeker, kan det eksistere flere sannheter samtidige omkring endringer av kollektiv handling i dag. For det første spiller digitale medier og medieplattformer viktige roller som verktøy for de engasjerte i mobilisering og koordinering av kollektiv handling. Likevel vil de digitale handlingene og hendelsene bare utgjøre en liten del av hva som skal til for å mobilisere og organisere kollektiv handling og engasjement. I tillegg vil de mange «mislykkede» aksjoner og revolusjoner, for eksempel «den arabiske våren», der digitale medier spilte sentrale roller, kunne stå som eksempler på grensene for hva ikke-hierarkiske, ikke-institusjonaliserte mobiliseringer kan få til (Wells, 2014). Argumentet om en ny form for kollektiv handling kan på denne måten kritiseres for manglende oppmerksomhet mot to viktige faktorer knyttet til kollektiv handling og samfunnsengasjement: 1) det faktum at sosiale faktorer (og ikke teknologiske) er med i å forme samfunnsengasjement, og 2) den fortsatt sentrale rollen som sivilsamfunnsorganisasjoner spiller for å mobilisere og strukturere samfunnsengasjement. (Wells, 2014).

Spørsmålet blir da om det som er beskrevet gjennom eksemplene i denne boken, kan tolkes som utviklingen av en ny form for kollektiv handling, eller om utviklingen i større grad handler om en tilpasning av tradisjonelle former for samfunnsengasjement og kollektiv handling til 
en samfunnskontekst mer preget av globale digitale kommunikasjonsnettverk. Her mener vi at bidragene i denne boken, sett under ett, ikke støtter tesen om fremveksten av en ny form for konnektiv handling. Både individer og organisasjoner har tatt i bruk digital kommunikasjonsteknologi. Effektene av digitale nettverk på samfunnsengasjement når det gjelder mobilisering og demokratisering, er positive, men begrenset. Nye kollektive initiativer er kjennetegnet av hybride organisasjonsformer som blander nettverk og hierarki som koordineringsprinsipper, men casene i denne boken peker på at bærekraft over tid i slike initiativ fordrer formell organisering og institusjonalisering av de i utgangspunktet nettverksbaserte relasjonene. Selv om initiativene i disse casene fortsatt er i utvikling, og selv om det er for tidlig å konkludere noe om hvordan de vil utvikle seg fremover, ser det ut som om de følger et mønster, der initiativene i startfasen er kjennetegnet av personlige interaksjoner gjennom nettverk basert på entreprenørskap, for videre å utvikle seg mot mer upersonlige interaksjoner innenfor institusjonelle og til en viss grad hierarkiske rammer (Bimber mfl., 2012).

Infrastrukturen som tradisjonelle frivillige organisasjoner danner i sivilsamfunnet, både som mobiliseringskapasitet og for å opprettholde det individualiserte frivillige engasjementet over tid, ser ut til å beholde en sentral rolle på tross av veksten i digitale kommunikasjonsnettverk. Som vist av Audun Fladmoe i kapittel 5, i forbindelse med flyktningsituasjonen, der nye frivillige initiativ i større grad enn de tradisjonelle organisasjonene relativt sett tiltrakk seg bidrag fra unge, lavt utdannede og lavtlønnede, mens andelen «nye» frivillige var begrenset - majoriteten av dem som bidro, hadde tidligere erfaring med organisasjonsfrivillighet. I tillegg når man undersøker hvem av de frivillige som deltok under flyktningsituasjonen i 2015 som fortsatt er frivillige ett år etter, viser det seg at det er en svært sterk sammenheng mellom det å delta i frivillig organisasjonsarbeid ett år før flyktningsituasjonen og ett år etter. I kjølvannet av individualiseringsprosesser har tradisjonelle og dedikerte former for engasjement i økende grad blitt erstattet av mer episodiske, uforpliktende og selvorienterte former for deltakelse (Hustinx, 2001, 2005, 2010). Likevel betyr ikke denne individualiseringsprosessen at samfunnsengasjement er avinstitusjonalisert. En grunn til det er at individualisering i seg 
selv er en institusjonell prosess. En annen grunn er at frivillige organisasjoner bidrar til å omstrukturere samfunnsengasjementet i ulike former for organisert individualisert engasjement (Hustinx, 2010).

De pådrivende endringsfaktorene når det gjelder samfunnsengasjement, ser ut til å være mer av sosial enn av teknologisk natur. Både individualisering og globalisering har konsekvenser for samfunnsengasjement - skillet mellom politisk og frivillig engasjement ser ut til å viskes ut på noen områder, og transnasjonale nettverk muliggjør handling både lokalt og globalt - men uten å endre på betydningen av sivilsamfunnsorganisasjoner på en fundamental måte.

\section{Referanser}

Alexander, J.C. (2006). The civic sphere. Oxford: Oxford University Press.

Almond, G.A., \& Verba, S. (1963). The civic culture. London: Sage.

Arnesen, D., Sivesind, K. H., \& Gulbrandsen, T. (2016). Fra medlemsbaserte organisasjoner til koordinering av frivillighet? Oslo: Senter for forskning på sivilsamfunn og frivillig sektor.

Beck, U. (1992). Risk society. London: Sage.

Benkler, Y. (2006). The wealth of networks. New Haven: Yale University Press.

Bennett, W.L., \& Segerberg, A. (2012). The logic of connective action. Information, Communication \& Society, 15(5), 739-768.

Bennett, W.L., \& Segerberg, A. (2013). The Logic of Connective Action: Digital Media and the Personalization of Contentious Politics. Cambridge: Cambridge University Press.

Bimber, B., Flanagin, A.J., \& Sthol, C. (2005). Reconceptualizing collective action in the comtemporary media environment. Communication Theory, 15(4), 365-388.

Bimber, B., Flanagin, A.J., \& Sthol, C. (2012). Collective action in organization. Interaction and engagement in an era of technological change. Cambridge: Cambridge University Press.

Castells, M. (1996). The information age : economy, society and culture. Vol. I: The rise of the network society. Oxford: Blackwell.

Castells, M. (1997). The information age : economy, society and culture. Vol. II: The power of identity. Oxford: Blackwell.

Castells, M. (1998). The information age : economy, society and culture. Vol. III: End of Millennium. Oxford: Blackwell.

Castells, M. (2001). The Internet galaxy, reflections on the Internet, businness and society. Oxford: Oxford University Press. 
Castells, M., \& Catterall, B. (2002). Making of the Network Society. London: Institute of Contemporary Art.

Castells, M. (red.) (2004). The network society. A cross-cultural perspective. Cheltenham: Edward Elgar.

Clark, P.B., \& Wilson, J.Q, (1961). Incentive Systems: A Theory of Organizations. Administrative Science Quarterly, 6(2), 129-166.

Earl, J., Hunt, J., Garrett, R.K., \& Dal, A. (2015). New technologies and social movements. I D. Della Porta \& M. Diani (red.), The Oxford Handbook of Social Movements. Oxford: Oxford University Press.

Ebaug, H.R., \& Chafetz, J.S. (red.) (2002). Religion across borders. Walnut Creek: Altamira Press.

Eimhjellen, I. (2014). Internet communication: Does it strengthen local voluntary organizations? . Nonprofit and Voluntary Sector Quarterly, 43(5), 890-909.

Eimhjellen, I., Strømsnes, K., \& Wollebæk, D. (2014). Accosiations online: Barriers for using web-based communication in voluntary organizations. Voluntas International Journal of Voluntary and Nonprofit Organizations, 25(3), 730-753.

Eliasoph, N. (1998). Avoiding politics. Cambridge: Cambridge University Press.

Juris, J.S. (2004). Networked social movements: global movements for global justice. I M. Castells (red.), The network society. A cross-cultural perspective. Cheltenham: Edward Elgar.

Kontopoulos, K.M. (1993). The logics of social structure. Cambridge: Cambridge University Press.

Lichterman, P., \& Eliasoph, N. (2014). Civic Action. American Journal of Sociology, $120(3), 798-863$.

MacKenzie, D., \& Wajcman, J. (1999). The social shaping of technology. Buckingham: Open University Press.

Margetts, H., John, P., Hale, S., \& Yassery, T. (2016). Political turbulences. How social media shape collective action. Princeton: Princeton University Press.

McCarthy, J.D., \& Zald, M.N. (1977). Resource mobilization and social movements: A partial theory. American Sociological Review, 82(6), 1212-1241.

Melucci, A. (1996). Challenging codes. Cambridge: Cambridge University Press.

Podolny, J.M., \& Page, K.L. (1998). Network forms of organization. Annual Review of Sociology, Vol. 24, 57-76.

Olson, M. (1965). The problem of collective action. Cambridge: Harvard University Press.

Orlikowski, W.J. (1992). The duality of technology: Rethinking the concept of technology in organizations. Organization Science 3, 398-427.

Sassen, S. (2002). Towards a sociology of information technology. Current Sociology $50,365-388$

Sassen, S. (2007). A sociology of globalization. London: Norton \& Co. 
Tarrow, S. (2005). The new transnational activism. Cambridge: Cambridge University Press.

Van Dijk, J. (2006). The network society. London: Sage.

Wells, C. (2014). Civic identity and the question of organization in contemporary civic engagement. Policy \& Internet, 6(2), 209-216.

Wells, C. (2015). The civic organization and the digital citizen. Oxford: Oxford University Press.

Westrum, R. (1991). Technologies \& society. The shaping of people and things. Belmont California: Wadsworth Publishing Company.

Zuckerman, E. (2014). New media, new civics? Policy \& Internet, 6(2), 151-168. 


\title{
KAPITTEL 2
}

\section{Politiske aksjoner i Norge: Hvilken rolle spiller organisasjonene?}

\author{
Kristin Strømsnes
}

Universitetet i Bergen

Steinar Gjerde

Universitetet i Bergen

\begin{abstract}
In this chapter, we analyze protests and demonstrations in Norway in the period between 1983 and 2016. The aim is to shed light on the role of different kinds of civil society organizations in the protest channel, and the relationship that exist between political and civic engagement. The analysis presented stem from two original datasets. The first one is built on the national assembly's own archive, where legal protests and demonstrations outside the assembly building are recorded. The second dataset is built on the compilation of recorded protests in Norway's largest newspapers, Aftenposten and Verdens Gang, and contains both legal and illegal protests carried out in Oslo or in other parts of Norway. We find a vibrant protest channel where a host of political and social issues are presented through various protest activities, and where a broad variety of organizations play an important role in organizing and executing demonstrations and protests. Even though there is evidence of informal networks and private initiatives that organize protests, the main bulk of activities are carried out by formal organizations. Hence, a limited amount of protests are considered spontanious and unorganized.
\end{abstract}

Keywords: civic engagement, protests, social movements, civil society organizations, Norway, demonstrations

Sitering av denne artikkelen: Strømsnes, K., \& Gjerde, S. (2018). Politiske aksjoner i Norge: Hvilken rolle spiller organisasjonene? I B. Enjolras \& I. Eimhjellen (Red.), Fra kollektiv til konnektiv handling? Nye former for samfunnsengasjement og kollektiv handling $i$ Norge (s. 31-62). Oslo: Cappelen Damm Akademisk. https://doi.org/10.23865/noasp.45.ch2 Lisens: CC BY-NC 4.0 


\section{Innledning}

I studier av kollektiv handling er det vanlig å skille mellom politisk og sivilt engasjement. Mens politisk engasjement handler om aktivitet som har til hensikt å påvirke politikken som føres enten lokalt, nasjonalt eller internasjonalt, viser sivilt engasjement til frivillig aktivitet for å hjelpe andre, oppnå et offentlig gode eller løse konkrete problemer i samfunnet (Verba, Schlozman \& Brady, 1995). Mens sivilt engasjement blir forbundet med verdier som altruisme, uegennytte og engasjement for andre, forbindes politisk engasjement med interessekamp og protest. På samme måte blir deltakelse i politiske aksjoner og i frivillige organisasjoner ofte sett på som to uavhengige fenomener, og det har lenge vært et dypt skille innenfor faglitteraturen mellom studier av frivillig organisering og av politiske aksjoner og sosiale bevegelser (se Henriksen \& Svedberg, 2010; Eliasoph, 2013). I dette kapitlet viser vi at de to fenomenene er tettere koblet sammen enn det dette skillet i faglitteraturen kan gi inntrykk av.

Temaet for kapitlet er hvilken rolle organisasjonene spiller innenfor aksjonskanalen. Vi er altså primært interessert i å studere hvilke aktører det er som står bak aksjonene i Norge. Er det enkeltpersoner og spontane aksjonsgrupper eller mer tradisjonelle organiserte interesser som står bak? Hvilke organisasjoner er det i så fall snakk om, og på hvilken måte tar de aksjonskanalen i bruk? I mindre grad handler kapitlet om enkeltindividers deltakelse i aksjoner eller om omfanget av eller det konkrete innholdet i aksjonene og endringene i dette over tid (se f.eks. Strømsnes \& Selle, 2014 og Helle \& Matos, 2018 for slike diskusjoner). Det er også i dette kapitlet de fysiske aksjonene vi studerer, og ikke den typen internettbaserte aksjoner som diskuteres i flere av de andre kapitlene i boken.

Kapitlet bygger på to originale datasett. Det første av disse tar utgangspunkt i tillatelser gitt av Stortingets eiendoms-, sikkerhets- og serviceavdeling til å gjennomføre aksjoner og markeringer på plassen utenfor Stortinget (Eidsvolls plass) i perioden 1996-2016. Dette materialet dekker lovlige aksjoner, det vil si aksjoner som det er søkt om, og som Stortinget har gitt tillatelse til. Aksjonene er geografisk, og i de aller fleste 
tilfeller politisk, knyttet til Stortinget som institusjon. ${ }^{1}$ Det andre materialet omfatter aksjoner som er omtalt i Aftenposten eller VG i perioden fra 1983 til 2015. Dette materialet inkluderer både lovlige og ulovlige aksjoner, aksjoner som finner sted også andre steder i Oslo enn foran Stortinget, i tillegg til aksjoner andre steder i landet som er av såpass omfang og interesse at riksdekkende Oslo-baserte aviser skriver om dem. De to datasettene er ulike, men i kombinasjon utfyller de hverandre og bidrar til å gi et bilde av aksjonskanalen i Norge. I tillegg til disse to datasettene refereres det til data fra European Social Survey (ESS) for å gi bakgrunnsinformasjon om omfanget av aksjonsdeltakelse i Norge sammenliknet med det som er situasjonen ellers i Europa.

Innenfor en norsk kontekst har det vært gjort lite forskning på politiske aksjoner, og vi vet relativt lite om hvordan politiske aksjoner oppstår, og hvem det er som står bak dem. Det meste av den forskningen som har vært gjort på politiske aksjoner i Norge, har handlet om individuell aksjonsdeltakelse og variasjoner i denne (Olsen \& Sætren, 1980; Togeby, 1989, 1993; Strømsnes, 2003). En har også studert enkeltaksjoner (som Alta-aksjonen eller Mardøla-aksjonen; f.eks. Parmann, 1980, Gleditsch, Hartmann, Naustdalslid, 1971), enkeltorganisasjoners bruk av aksjonskanalen (f.eks. Kielland, 2017) eller kjennetegn ved protesthendelser (Kjellman, 2007). Når vi her retter søkelyset eksplisitt mot organisasjonene som står bak aksjonene, representerer det en ny tilnærming innenfor et felt der vi så langt har lite kunnskap.

Kapitlet starter med en gjennomgang av teoretiske forventninger om sammenhengen mellom aksjonskanalen og organisasjonskanalen før vi, etter å ha diskutert datamaterialet og tilnærmingen vår, presenterer det empiriske bildet som materialet viser oss, og diskutere organisasjonenes rolle innenfor aksjonskanalen med bakgrunn i dette. Siden det er snakk om et datamateriale som for en stor del blir presentert her for første gang, legges det også vekt på å beskrive hvordan materialet er bygd opp, og diskutere fordeler og ulemper ved de metodiske valgene som er tatt.

1 Som vi skal se, er det en rekke aktører som er aktive innenfor aksjonskanalen. Selv om ikke alle har et eksplisitt politisk budskap, kan det argumenteres for at det ligger en politisk kobling i det å legge markeringen til plassen foran stortingsbygningen. 


\section{Organisasjoner, aksjoner og frivillighet}

Nye utviklingstrekk knyttet til økende globalisering, individualisering og digitalisering blir ofte antatt å lede i retning av at den kollektive organiseringen står svakere nå enn den gjorde tidligere. Parallelt har man også registrert en nedgang i tradisjonelle former for politisk engasjement, som valgdeltakelse og partimedlemskap. Det pekes på at samfunnsborgerne ønsker en mindre forpliktende deltakelse og i større grad engasjerer seg fra sak til sak og over et kortere tidsrom (f.eks. Dalton, 2006; Norris, 2002; jf. også innledningskapitlet til denne boken). Bildet som gis, er dermed at det politiske engasjementet nå i større grad handler om en flyktig og mindre forpliktende nettverkstilkobling, der individet spontant engasjerer seg for en kortere periode i et tema som er viktig der og da. Dette engasjementet leder ikke nødvendigvis til at en forplikter seg over tid, eller til lojalitet til en organisert gruppe og det den står for. Politiske aksjoner blir ofte tolket innnefor slike rammer, der aksjonsdeltakelse blir forstått som en form for engasjement som skjer ad hoc - knyttet til en bestemt sak, ofte over en kort tidsperiode og uten at det trenger å stå en tung organisering bak (se Olsen \& Sætren, 1980).

På den annen side er det lite som tyder på at politiske aksjoner skjer frikoblet fra den organiserte delen av sivilsamfunnet. Selv om en sosial bevegelse ikke kan reduseres til organisasjonene som er en del av bevegelsen, spiller organisasjonene en svært viktig rolle for sosiale bevegelser, og dermed også i politiske aksjoner. For å gjennomføre aksjoner trengs det normalt et apparat som fordeler oppgaver, og en komité som tar seg av alt fra paroler og diskusjon av virkemiddelbruk til kontakt med presse og samarbeidspartnere. Samtidig kan aksjonene være et viktig virkemiddel for organisasjonene, ikke bare for å gi uttrykk for det organisasjonen står for, og søke politisk innflytelse, men også for å rekruttere og mobilisere medlemmer og sympatisører. Ikke minst innenfor vårt system er det grunn til å anta at organisasjonene spiller en sentral rolle. Organisasjonene i Norge har tradisjonelt hatt en viktig politisk rolle, og ikke vært de frakoblede, lokale problemløserne som man kan se beskrevet i mye av litteraturen, inkludert i Verba et al. (1995) klassiske skille mellom politisk og sivilt engasjement. 
Selv om politiske aksjoner antas å ha fått større appell, er det langt fra snakk om et nytt fenomen. Særlig på 196o-tallet fikk de politiske aksjonene en oppblomstring, med nye krav og nye uttrykksmåter, og som gjorde at mange begynte å snakke om dette som en «ny» form for politisk engasjement (Bjereld \& Demker, 2018). På denne tiden oppsto det en rekke nye sosiale bevegelser som tok i bruk aksjonskanalen som sin viktigste arena. Disse bevegelsene var ofte løst organisert, uten noen fast organisasjonsstruktur, og de befant seg ofte på siden av det «normale», representative systemet. Konfliktnivået var høyt, og en prøvde å oppnå innflytelse gjennom å bruke aksjonskanalen til å tiltrekke seg makthavernes eller medienes oppmerksomhet. Etter hvert har imidlertid politiske aksjoner gått fra å regnes som en ukonvensjonell form for politisk deltakelse, en deltakelsesform primært for de som ikke så lett slipper gjennom de mer etablerte innflytelseskanalene, til å inngå som en del av det ordinære demokratiske deltakelsesrepertoaret (Barnes \& Kaase et al., 1979; Meyer \& Tarrow, 1998; Lindekilde \& Olesen, 2015).

Fra å tradisjonelt ha blitt forstått som noe som oppstår spontant og med grunnlag i omfattende frustrasjon og misnøye i befolkningen (f.eks. Gamson, 1975), blir politiske aksjoner og protester altså i økende grad sett som en normal og rasjonell del av politikken; de har blitt en del av rutinepolitikken. Det snakkes i den sammenheng også om at de politiske aksjonene har blitt profesjonalisert og institusjonalisert, og at vi i økende grad har sett fremvekst av det som blir betegnet som «movement societies» (Meyer \& Tarrow, 1998; Soule \& Earl, 2005; Quaranta, 2017). I det ligger det at politiske aksjoner har blitt vanligere, de tas i bruk av et langt større spekter av politiske aktører og for en rekke ulike formål. Mens en tidligere gjerne forbant politiske aksjoner med spontane protesthandlinger utført av frustrert ungdom på utsiden av det politiske systemet, ligger det i forestillingen om «Movement societies» at det nå oftere er etablerte organisasjoner som står bak. Dette antas videre å ha en modererende effekt på aksjonene.

I kontrast til denne beskrivelsen opplever vi parallelt en utvikling der en stadig større del av aksjonsdeltakelsen og protestaktiviteten skjer på internett, og vi har sett en forskyvning fra tradisjonell kollektiv handling til det som Bennett og Segerberg (2013) kaller konnektiv handling. 
Innenfor denne tilnærmingen blir organisasjonenes rolle i organisering av aksjoner og protest mindre viktig fordi nettverkene som er avgjørende for deltakelse, nå friere kan kommunisere direkte gjennom åpne sosiale plattformer på internett. I dette kapitlet skal vi imidlertid konsentrere oss om de fysiske aksjonene, mens ulike former for internettbasert organisering vil bli grundigere analysert $\mathrm{i}$ andre kapitler i boken.

\section{Hvilken rolle spiller organisasjonene?}

Forskningen på politiske aksjoner kan grovt deles inn i tre hovedtilnærminger (Quaranta, 2017). Den første tilnærmingen er den individbaserte forskningen som studerer trender og variasjoner i individuell deltakelse i protestaksjoner. Denne er som regel basert på surveydata, og inkluderer forskning på motivasjon for deltakelse, deltakelsesressurser og endringer i omfanget av deltakelse. Den andre tilnærmingen studerer sosiale bevegelser og aksjonsgrupper, og er ofte konsentrert om kjennetegn og strategier knyttet til konkrete bevegelser og nettverk med vekt på hvordan den politiske konteksten gir ulike mulighetsstrukturer for sosiale bevegelser. Man ser gjerne her for seg at det eksisterer en omvendt kurvlineær sammenheng mellom hvor åpent eller lukket et politisk system er, og grad av politisk protest, der en finner mindre innslag av politiske aksjoner både i svært lukkede og i svært åpne systemer (Eisinger, 1973). Den siste tilnærmingen er forskningen som tar utgangspunkt i ulike protesthendelser, gjerne basert på nyhetskilder, og som studerer hva som kjennetegner politiske aksjoner, og hvordan dette eventuelt har endret seg over tid. I vår studie vil vi bruke elementer fra alle disse tilnærmingene, men med hovedvekt på den siste, der vi bruker event-data til å undersøke den rollen organisasjonene spiller innenfor aksjonskanalen.

Når man studerer protestdeltakelse på individnivå, blir medlemskap og aktivitet i ulike typer organisasjoner sett på som en ressursvariabel på linje med variabler som utdanning og inntekt. Den internasjonale faglitteraturen viser at medlemskap i sivilsamfunnsorganisasjoner korrelerer sterkt med deltakelse i direkte aksjoner, og at organisasjonstilknytning er viktig for å rekruttere deltakere (Somma, 2010; Lim, 2008). Det finnes flere eksempler på studier som avdekker dette mønsteret, både i USA og 
i Europa. Av de klassiske amerikanske studiene kan man trekke fram Freedom Summer-prosjektet (McAdam, 1986; McAdam \& Paulsen, 1993), der man kontrollert for andre individnivå-variabler fant en positiv sammenheng mellom deltakelse i høyrisikoaksjoner og tilhørighet til organisasjoner. Analyser på 200o-tallet avdekket det samme mønsteret i USA, på tvers av etniske og religiøse grupper, for eksempel i Fitzgerald og Spohns (2005) studie av afroamerikanske grupper, Martínez' (2005) studie av latinamerikanske grupper og McVeigh og Sikkinks (2001) studie av religiøst aktive protestanter.

Innenfor en europeisk kontekst finner vi den samme positive sammenhengen i studier av Los Indignados i Spania og Italia etter protestene i kjølvannet av finanskrisen (della Porta, Mosca \& Parks, 2015), blant de politiske undergrunnsgruppene i London og i den engelske Occupybevegelsen (Deel \& Murray-Leach, 2015) og blant polske aktivister under protestene mot ny abortlov i 2016 (Korolczuk, 2016). I nyere asiatiske studier viser også analyser av demokratiprotestene i Hongkong at man finner en tydelig sammenheng mellom villighet til å delta i protester og tilknytning til ulike grupper og organisasjoner i sivilsamfunnet (Cheng, 2016).

At personer som tar del i aksjoner, i større grad enn andre innehar organisasjonsmedlemskap, er med andre ord ikke overraskende. Dette er også en sammenheng vi finner innenfor norsk kontekst, som for eksempel i Olsen og Sætrens klassiske studie fra den første maktutredningen, der de demonstrerte hvordan de som var aktive i aksjonskanalen, også var aktive gjennom de andre kanalene for politisk innflytelse, inkludert organisasjonskanalen (Olsen \& Sætren, 1980).

Medlemskap i ulike typer uformelle grupper og etablerte organisasjoner fungerer med andre ord ofte som rekrutteringsnettverk for kollektiv handling (della Porta \& Diani, 2006). I tillegg er organisasjonene viktige som diskusjons- og nettverksarenaer, og som organiseringsplattformer for fysiske aksjoner. De er også instrumentelle i prosessen med å knytte andre institusjoner eller aktører til arbeidet slik at en aksjon kan gjennomføres i praksis. Dette ser vi både i studier av sosiale bevegelser på 1960- og 70-tallet (Johnson, 1983; Gerlach, 1999) og i studier av moderne aksjoner som i London i regi av Occupy-bevegelsen (Deel \& MurrayLeach, 2015). 
Et klassisk eksempel som illustrerer viktigheten av organisasjoner og organisatorisk tilknytning til andre institusjoner, finner vi i USA på 1970-tallet. Amerikanske funksjonshemmede ønsket å rette søkelyset mot sin situasjon og den manglende tilgangen til sivilsamfunnet på grunn av sine handicap. I flere byer forsøkte man å organisere sit-ins og demonstrasjoner, men aksjonene ble svært kortvarige. Bevegelsen manglet organisatorisk støtte og samarbeidspartnere hos sentrale sivilsamfunnsorganisasjoner, og hadde ikke bygd en organisasjonsplattform som kunne forvalte budskapet eller koordinere innsatsen (Johnson, 1999). Dermed forvitret aksjonen etter bare noen timer i Denver og San Fransisco, mens man holdt ut i et par dager i Los Angeles. I Green Bay fungerte derimot aksjonen på et helt annet nivå. Her hadde man fått hjelp av det amerikanske Blindeforbundets organisasjon, samtidig som offentlige etater gjennom Blindeforbundet knyttet seg til aksjonen. Organisasjonen fungerte da som koordinator på bakken for aksjonistene, og samtidig som en forvalter og koordinator av støtte fra øvrige sivilsamfunnsorganisasjoner og politiske institusjoner (Freeman \& Johnson, 1999).

Et nyere eksempel er organisasjonsbygging og reetablering av sivilsamfunnsorganisasjoner som del av kampen mot den nye polske abortloven. Her etablerte man nye organisasjoner fra grunnen dersom man manglet dem, eller man knyttet til seg organisasjoner man hadde jobbet sammen med tidligere. Dermed ble prosessen for kvinnebevegelsen å skape nye organisasjoner og å knytte seg til eksisterende foreninger. Også politikere og politiske partier forsøkte å knytte seg til aksjonen, men på grunn av stor mistillit til politikere og staten generelt ble slike forsøk holdt på en armlengdes avstand (Korolczuk, 2016). De kontekstuelle rammene aksjonene foregår innenfor, er med andre ord av stor betydning.

\section{Aksjonsdeltakelse i Norge}

Det vi studerer i dette kapitlet, er sammenhengen mellom aksjonskanalen og organisasjonskanalen i Norge; en ganske annen kontekst enn det polske eksempelet ovenfor. Hvordan fungerer aksjonskanalen i et land som Norge, der vi finner høy grad av organisering og et nært forhold mellom organisasjonene og det offentlige? Er det slik at det politiske 
engasjementet blir kanalisert via organisasjonene og inn i politikken gjennom ulike korporative ordninger, og at det i mindre grad er behov for politiske aksjoner på utsiden av dette systemet? Og betyr det i så fall at organisasjonene i mindre grad engasjerer seg i ulike former for markeringer i det offentlige rom? Eller vil et åpent politisk system som det norske være åpent også for politiske protester fra ulike organiserte og uorganiserte grupper i samfunnet?

Om vi tar utgangspunkt i individdata, er omfanget av aksjonsdeltakelse relativt høyt i Norge. European Social Survey (ESS), som er blitt gjennomført i en rekke europeiske land annethvert år fra 2002 til 2016, viser at mellom 7 og 11 prosent av de spurte i Norge sier at de har deltatt i en lovlig offentlig demonstrasjon i løpet av de siste tolv månedene (online analyse, European Social Survey 2018). Det har ikke vært noen økning i andelen over tid, verken når vi ser på data fra Norge eller på de samlede ESS-dataene. Andelen som deltar blant nordmenn, ligger 1-4 prosentpoeng over gjennomsnittet, og dermed på nivå med Tyskland. Nivået ligger på den annen side et godt stykke under det som vi finner i Spania (16-34 prosent) og Frankrike (11-17 prosent), mens en rekke østeuropeiske land, samt Nederland, utmerker seg med lav deltakelse i offentlige demonstrasjoner.

Også blant de nordiske landene ligger Norge relativt høyt, bare forbigått av Island (15-27 prosent). Lavest ligger Finland, der en svært liten andel av befolkningen sier at de har deltatt i offentlige demonstrasjoner de siste tolv månedene (under 4 prosent). Både Danmark og Sverige ligger jevnt over litt under nivået i Norge (4-9 prosent), men i Sverige har andelen økt betraktelig siden 2010, og er nå på linje med nivået vi finner i Norge.

Ikke bare på individnivå (enkeltindividers engasjement), men også på organisasjonsnivå (organisasjonenes engasjement), kan det være gode grunner til å anta at nivået er høyt i Norge. Norge har tradisjonelt vært kjennetegnet av stor grad av kollektiv organisering, der alt som har blitt sett på som viktig, også har vært organisert. Organisasjonenes muligheter for politisk innflytelse har også vært svært gode innenfor et politisk system som i stor grad har vært åpent og lydhørt overfor ulike organiserte interesser (Klaussen \& Selle, 1995; Enjolras \& Strømsnes, 2018; Grendstad, 
Selle, Strømsnes \& Bortne, 2006). Det finnes også en rekke formelle og institusjonaliserte ordninger der organiserte grupper kan påvirke de politiske beslutningene gjennom å bli tatt med på råd, konsultert i viktige saker og bedt om å gi sine uttalelser. Samtidig har det vært et lavt konfliktnivå mellom borger og stat, og et liberalt syn på politiske aksjoner. Man kan kanskje si at det norske politiske systemet åpner opp et eget mulighetsrom for organisasjonene til å benytte seg av aksjonskanalen. Dette vil ha betydning for hvilken type organisasjoner vi kan forvente å finne her, for eksempel at det antakelig er snakk om et langt større spenn enn bare utpregede «politiske» organisasjoner. Videre er det naturlig å anta at det er sammenheng mellom organisering og hvilke aksjonsformer som tas i bruk, der mer omfattende demonstrasjoner antakelig krever en høyere grad av organisering enn mindre krevende punktdemonstrasjoner, der hendelsen er begrenset i tid og rom og det ofte er færre aktører involvert.

\section{Data og tilnærmingsmåte}

Eidsvolls plass utenfor Stortinget er en sentral arena for demonstrasjoner i Norge, på samme måte som områder foran parlamenter er det i mange andre land (Strømsnes \& Selle, 2014). Ikke bare er dette et område som er åpnet opp for demonstrasjoner og markeringer, men aksjoner er også noe som Stortinget oppfordrer til. I Stortingets undervisningsmateriell rettet mot videregående skole fremheves for eksempel viktigheten av politisk deltakelse gjennom demokratiets mange deltakelseskanaler: «Bruk stemmeretten ..., ta kontakt med politikere ..., bli medlem av et parti ..., gå til aksjon ..., meld deg inn i en organisasjon ..., bruk mediene ...» (Stortinget, 2018a). Om aksjoner heter det videre at «[k]larer du å få med deg mange mennesker på aksjonen, og særlig hvis [du] greier å få media til å dekke saken, øker sjansene for at du blir hørt av politikerne på Stortinget eller lokalt - der du bor» (Stortinget, 2018b). Politiske aksjoner blir med andre ord fremhevet som en viktig og legitim del av det norske demokratiet. Dette forteller ikke så rent lite om den åpenheten som eksisterer i det norske systemet, og som står i klar kontrast til tendensen i litteraturen om aksjoner og sosiale bevegelser til å peke på fremmedgjøring og 
konflikt som de viktigste faktorene for å forklare hvorfor politiske aksjoner oppstår (Strømsnes, 2018).

Adgangen til Eidsvolls plass er imidlertid regulert, og for å aksjonere lovlig her må man på forhånd ha søkt Stortingets eiendoms, sikkerhetsog serviceavdeling om tillatelse til å holde en markering. Det første datamaterialet vi skal bruke i dette kapitlet, bygger nettopp på disse søknadene, der vi med utgangspunkt i brevjournalen til Eiendoms-, sikkerhets- og serviceavdelingen har registrert alle tillatelser som er gitt til å holde markeringer og demonstrasjoner på Eidsvolls plass i perioden fra 1996 til 2016. ${ }^{2}$ I alt inkluderer materialet 4495 markeringer og demonstrasjoner i denne perioden, noe som betyr at det stort sett gjennomføres én politisk markering foran Stortinget hver eneste hverdag året rundt (se også Stortinget, 2017). De hendelsene som er inkludert i materialet, er hendelser som kan klassifiseres enten som markeringer eller arrangementer, eller som demonstrasjoner. Det er altså ikke bare protestaksjoner det handler om, men ulike markeringer der målet er å formidle et budskap til et publikum som befinner seg enten på innsiden eller på utsiden av stortingsbygningen, til politikerne eller til offentligheten. Kommersiell bruk av plassen, idrettsarrangementer (f.eks. Sentrumsløpet) og filminnspillinger og TV-opptak er ikke inkludert.

Vi baserer materialet på hvordan Stortinget selv har klassifisert hendelsene i sine journaler, og har i kodingen av materialet brukt Stortingets egne betegnelser på aktiviteten. De skiller her mellom «Markering eller arrangement», «Stand», «Punktmarkering», «Demonstrasjon», «Punktdemonstrasjon, streik, sultestreik», «Demonstrasjonstog» og «Lys, fakkeltog og fanemarkering». Mens de tre førstnevnte primært handler om å formidle et standpunkt eller budskap, vil de fire siste i større grad inneholde et element av protest. Det er imidlertid vanskelig å trekke absolutte skiller her siden materialet sier lite om det konkrete innholdet i aksjonene. Materialet inneholder også langt mer enn det vi vanligvis tenker på som politiske aksjoner. Særlig er begrepet «markering» som Stortinget opererer med, et

2 Takk til Institutt for sammenliknende politikk ved Universitetet i Bergen for støtte til innsamling og registrering av dette materialet, og til Stortingets eiendoms-, sikkerhets- og serviceavdeling for å ha stilt det til disposisjon. 
vidt begrep. En «markering» kan være alt fra en informasjonsstand til en folkesamling som forsøker å overbevise publikum og politikere i en sak. Det trenger ikke å ha noe element av protest i seg, men det kan også ha det. ${ }^{3}$

Den informasjonen som materialet gir oss, omfatter ellers slike ting som tidspunkt for markeringen, aksjonsform og hvem det er som står bak markeringen. Vi har i tillegg kodet hvorvidt det er enkeltpersoner eller organisasjoner som står bak søknadene, og hvilke organisasjoner det er snakk om der det er organisasjoner som står bak. Organisasjonene er kodet med utgangspunkt i The International Classification of Non-profit Organizations (ICNPO) og tilpassingen av dette klassifikasjonsskjemaet til norske forhold (Sivesind, 2012). ${ }^{4}$

Selv om materialet gir oss en god oversikt over markeringer rettet mot Stortinget, og hvilke aktører det er som benytter denne arenaen for å fremme synspunktene sine og drive påvirkningsarbeid, inkluderer det ikke alt som gjennomføres av aksjoner i Norge. Materialet er begrenset både når det gjelder lokasjon (Eidsvolls plass), og ved at det bare inkluderer lovlige aksjoner.5 Det er også sparsomt med informasjon i dette materialet om det konkrete innholdet i aksjonene. Vi supplerer derfor materialet med en annen datakilde, der vi baserer oss på informasjon om politiske aksjoner slik det fremkommer i de største norske avisene.

Den vanligste kilden å benytte for innsamling av data om politiske aksjoner er mediedekning av enkelthendelser (event-data) (se f.eks. Rucht, Koopmans \& Neidhard, 1999; Kriesi, Koopmans, Duyvendak \& Giugni, 1995; Mikkelsen, 2002). I det andre datamaterialet som vi skal

3 Det er eksempler i materialet på at organisator søker om tillatelse til å arrangere en aksjon eller en demonstrasjon, og at Stortinget i sitt svar godkjenner «markeringen». I 2012 endres dessuten systemet for journalføring, slik at det kun er markert at henvendelsen er «besvart». Det gjør at vi etter dette tidspunkt må basere klassifiseringen på hvilken betegnelse søker selv har brukt (men som kan være vel så presis som den Stortinget benytter).

4 The International Classification of Non-profit Organizations (ICNPO) er klassifikasjonssystemet for frivillige organisasjoner som anbefales i FNs Handbook on Non-profit Institutions in the System of National Accounts, og som også brukes i norsk statistikkproduksjon på området, f.eks. undersøkelsene om frivillig innsats (se Henriksen, Strømsnes \& Svedberg, 2019), i det norske satellittregnskapet for frivillige organisasjoner og i Brønnøysundregisterets frivillighetsregister.

5 Dessverre gir ikke materialet mulighet til å si noe sikkert om omfanget av, og hvilke, søknader som blir avslått, men vi vil anslå det til å være en svært liten andel. De få avslagene som er registrert i materialet, dreier seg stort sett om at plassen allerede er opptatt. 
benytte, har vi brukt denne tilnærmingen, der vi har registrert ulike former for politiske demonstrasjoner i Norge basert på to sentrale mediekilder i perioden $1983-2015 .{ }^{6}$ Materialet er bygd opp med utgangspunkt i Retrievers digitale nyhetsarkiv, der vi har brukt Aftenposten og VG som kilder, og «demonstr* ${ }^{\star}$ som søkestreng. Dette har resultert i et datamateriale som inkluderer 2088 hendelser i det aktuelle tidsrommet, ofte med flere avisartikler som kilde for hver hendelse (høyeste verdi er 26, gjennomsnittsverdien er 1,44).7 Det er altså også her, som i materialet som omhandler markeringer på Eidsvolls plass, hendelser som er registrert og som utgjør analyseenhetene i materialet, selv om typen hendelser som inkluderes, er ulik. Mens materialet basert på Stortingets brevjournal inkluderer et bredt spekter av lovlige markeringer, inkluderer materialet basert på mediekilder både lovlige og ulovlige demonstrasjoner, og hendelsene handler mer eksplisitt om protest. Det er i begge tilfeller primært snakk om «outsider»-taktikker (f.eks. protester, demonstrasjoner, sivil ulydighet og voldelige aksjoner) i motsetning til «insider»-taktikker (f.eks. underskriftslister, brevskriving og bruk av rettsvesenet) (se Soule og Earl, 2005), selv om det også kan være snakk om en kombinasjon av virkemidler (f.eks. en demonstrasjon som ender i en overlevering av underskriftslister til en statsråd).

Aftenposten og VG er valgt som kilder i oppbyggingen av dette datasettet. Det er snakk om landets to største aviser, den ene en abonnementsavis og den andre en tabloidavis, som begge har elektronisk arkiv tilbake til 1983. Det kan innvendes at det er to Oslo-baserte riksaviser, noe som medfører at aksjoner som finner sted i andre byer og lokalsamfunn rundt om i landet, ikke vil være dekket inn i like stor grad som aksjoner som skjer i Oslo. Det er i tillegg snakk om to aviser som politisk heller mot høyre (selv om det bare er for Aftenposten at dette offisielt er

\footnotetext{
6 Vi har mottatt støtte til innsamling og koding av dette materialet fra Institutt for sammenliknende politikk ved Universitetet i Bergen, prosjektet 'Stortingets historie 1964-2014', samt Senter for forskning på sivilsamfunn og frivillig sektor.

7 Kjellman (2007) bruker i sitt arbeid en tilnærming som er beslektet med den som vi bruker her, med Aftenposten som kilde og NTB som kontroll. Han bruker imidlertid litt andre søkeord enn det vi gjør (aksjon, demonstrasjoner og opptøyer), og datamaterialet hans går kun frem til 2003. Norge var også involvert i et europeisk prosjekt som registrerte protesthendelser i 28 europeiske land i perioden 1980-1995 (Francisco, udatert).
} 
tilkjennegitt), noe som også kan ha betydning både for hvorvidt hendelser dekkes, og hvordan de omtales. Begge disse faktorene må tas med i betraktningen når materialet tolkes. Ideelt sett hadde det vært ønskelig å ta med flere aviskilder, inkludert region- og lokalaviser og aviser innenfor et bredere politisk spekter, men dette er noe som tilgjengelige ressurser har satt begrensninger for.

Bakgrunnen for valg av tidsrom er at 1983 er det året Retriever startet sitt digitale nyhetsarkiv. ${ }^{8}$ Søkestrengen som er brukt i oppbyggingen av materialet («demonstr*»), er valgt fordi den har vist seg godt egnet til å fange opp det fenomenet vi er interessert $\mathrm{i}$, sammenlignet med andre mulige søkeord som «protest», «aksjon» og «aksjonisme». Samtidig gir søkestrengen naturligvis også en rekke treff som ikke omhandler politiske aksjoner. Alle treff har derfor blitt gjennomgått manuelt, der bare de som faktisk omhandler politiske aksjoner, er registrert og kodet. I tillegg til den kvantitative kodingen av materialet er også alt materialet samlet i et arkiv som gjør det mulig å mer substansielt studere de hendelsene som inngår, og som gir grunnlag for en dypere forståelse enn det kvantitative materialet alene.

Slike event-data er en god kilde for å kunne si noe om konkrete protestaksjoner og andre hendelser, men både på grunn av utvalgsskjevheter (selection bias) og skjevheter i avisenes beskrivelse av hendelsene (information bias) vil de ikke gi noe absolutt bilde av det som skjer i aksjonskanalen (Earl, Martin, McCarthy \& Soule, 2004; Jenkins \& Maher, 2016). Denne typen event-data vil alltid være preget av nyhetskildenes prioriteringer. Utvalget av aksjoner i materialet vil være styrt av hva media til enhver tid finner det interessant å rapportere om (og hvilke andre nyhetshendelser som skjer samtidig), og vil derfor ikke gi noe nøyaktig bilde av alle hendelser som finner sted. Det er også nærliggende å anta at det vil være en overrepresentasjon av aksjoner som tilfredsstiller journalismens nyhetskriterier, ved at de omhandler noe man tror vil være av nasjonal

8 Strømsnes og Selle (2014) analyser demonstrasjoner rettet mot Stortinget tilbake til 1964, basert på data fra Aftenpostens arkiv lagret på mikrofilm for perioden før 1983. Vi har likevel her valgt å konsentrere oss om det digitale arkivet, noe som har gjort søkearbeidet lettere og datainnsamlingen mer lik over tid. I stedet har vi valgt å utvide datamaterialet med en ekstra datakilde (VG), og inkludere aksjoner rettet mot andre institusjoner enn Stortinget. 
interesse, er nytt, konfliktfullt og involverer kjente personer (Allern, 2001). Dette gjør at en for eksempel vil forvente en overrepresentasjon av store aksjoner og av voldelige aksjoner. Som vi skal komme tilbake til, vil heller ikke mediematerialet alltid være så nøyaktig i angivelsen av hvem det er som står bak aksjonene. I tillegg er det ikke utenkelig at medias oppfatning av hva som har nyhetsverdi og er verdt å gi spalteplass, er noe som har endret seg over tid. ${ }^{9}$ Det vil dermed være vanskelig å vite sikkert om endringer i omfanget av aksjoner og innholdet i disse skyldes faktiske endringer eller endringer i hva som gis mediedekning. Dette legger visse begrensninger for hvilke slutninger det er mulig å trekke basert på materialet.

Selv om det er mange aksjoner med i det datamaterialet som vi benytter her, er det også viktig å være klar over at materialet langt fra dekker alle de aksjonene som har funnet sted i Norge i det aktuelle tidsrommet. ${ }^{10}$ Sammenligner vi med datamaterialet som viser markeringer på Eidsvolls plass, så fanger dette opp over tre ganger så mange hendelser som materialet basert på mediedekning. På den annen side inkluderer materialet basert på Stortingets brevjournal et langt større spenn av hendelser, fra informasjons- og folkeopplysningsvirksomhet til protestaksjoner og demonstrasjoner. Vi vil imidlertid argumentere for at også den første typen påvirkningsarbeid er en viktig del av aksjonskanalen. Det blir for enkelt, slik for eksempel Rucht (1998, s. 34) gjør, å si at det kun er protester som de største medieaktørene rapporterer om, som er relevante siden det er disse som har mulighet for å oppnå offentlig oppmerksomhet og, eventuelt, politisk innflytelse.

En annen innvending med relevans for det vi studerer her, er at materialet basert på søknader til Stortinget, på bakgrunn av selve søknadsprosessen, antakelig vil tendere til å overrapportere andelen aksjoner som det står organisasjoner bak, mens materialet basert på

9 Dette er nært relatert til diskusjonen om den sosiale konstruksjonen av virkeligheten. Se f.eks. Gamson, Croteau, Hoynes \& Sasson (1992).

10 Unntaksvis inkluderer også materialet enkelte aksjoner som har funnet sted utenfor landets grenser, der norske organisasjoner har deltatt i større mønstringer i utlandet (totalt 14 hendelser). Eksempler er fredsbevegelsen i Norge, som drar til Tyskland for å demonstrere for fred i påskeferien i 1984, eller sjøfolk som demonstrerer mot staten eller eget rederi utenfor norske konsulat og ambassader. 
mediekilder vil tendere til å underrapportere det. Vi vil likevel argumentere for at de to datakildene vi har utfyller hverandre og, selv om de ikke alltid kan gi oss helt eksakte tall, kan bidra til å gi oss bedre innsikt i aksjonskanalen i Norge. Materialet dekker et langt tidsrom og et betydelig antall aksjoner innenfor dette tidsrommet. De to datakildene er ikke direkte sammenlignbare, men gir oss ulike innfallsvinkler til samme fenomen. Nettopp dette er også noe som har vært etterlyst i studier av politiske aksjoner (Quaranta, 2017). La oss gå over til å se hva materialet forteller oss.

\section{Hvem står bak markeringene på Eidsvolls plass?}

Eidsvolls plass utenfor Stortinget er, som vi har sett, en sentral arena for politiske markeringer i Norge, med om lag én markering hver eneste hverdag året rundt (Stortinget, 2017). Analysen av hvem det er som søker om å avholde slike markeringer, viser også et stort spenn, alt fra grupper i klar opposisjon til rådende oppfatninger i samfunnet (som Blitz, Gateavisa og Sian) til grupper som også er vel representert på innsiden av stortingsbygningen (som de enkelte partienes stortingsgrupper). Blant de mer kuriøse søknadene i materialet er Foreningen for syriske kurdere, som søker om å få arrangere sultestreik utenfor Stortinget over en femdagersperiode i 2010, riktignok begrenset hver dag til mellom klokken 13.00 og 17.00 (innvilget), og nynazister som søker om tillatelse til å markere Rudolf Hess' dødsdag utenfor Stortinget i 2000 (søknad oversendt Oslo politidistrikt, der den ifølge VG (2000) ble avslått «fordi tid og sted ikke passer»).

I Stortingets protokoll over innvilgede søknader om markeringer på Eidsvolls plass registreres det hvem som er ansvarlig for markeringen (søker), som kan være både enkeltpersoner og organisasjoner. Vi er her interessert i hvorvidt det primært er organisasjoner som søker om å få gjennomføre denne typen makeringer - og eventuelt hvilke organisasjoner eller om dette er en kanal for mer spontane markeringer arrangert på initiativ fra enkeltpersoner og mer uformelle nettverk. ${ }^{11}$ Vi finner at det $\mathrm{i}$

11 Det kan naturligvis alltid diskuteres når noe har såpass faste rammer at det kan kalles en organisasjon. Det organisasjonsbegrepet vi opererer med her, er vidt. Alt som er oppført med et organisasjonsnavn, er kodet som en organisasjon, uten at det er stilt krav om grad av 
62 prosent av tilfellene er norske enkeltorganisasjoner som står bak søknadene, i fem prosent av tilfellene er det snakk om flere grupperinger eller organisasjoner som søker sammen, mens det i 22 prosent av tilfellene er internasjonale organisasjoner som står bak. Bare i 12 prosent av tilfellene er det enkeltpersoner eller mer uformelle nettverk som står som søker. Selv om dette materialet antakelig tenderer til å overrapportere omfanget av organisasjoner (jf. diskusjonen om data i forrige avsnitt), tyder det likevel på at organisasjonene spiller en sentral rolle innenfor aksjonskanalen i Norge, og at aksjonskanalen langt fra er så spontan og uorganisert som mye av litteraturen antyder.

I tillegg til omfanget av aksjoner som det står organiserte interesser bak, finner vi en del interessante trekk når vi over tid studerer antallet aksjoner som ulike typer aktører står bak (Figur 2.1). For det første finner vi at det har vært en økning i denne typen markeringer i løpet av den perioden vi ser på, fra godt under 100 aksjoner årlig de første årene til rundt 300 i året i slutten av perioden. For det andre er det også tydelig at det er enkeltorganisasjoner som står for det meste av denne veksten. Dette kan indikere at aksjonsformen i dag krever mer organisering og ressurser enn det som var vanlig tidligere (se også Strømsnes \& Selle, 2014, s. 481), noe som stemmer godt overens med litteraturen om utvikling i retning av et «bevegelsessamfunn» («movement society», se Meyer \& Tarrow, 1998; Soule \& Earl, 2005). I tillegg ser vi at ulike internasjonale organisasjoner oftere har markeringer foran Stortinget nå enn det som var tilfellet i begynnelsen av den perioden vi ser på, noe som også stemmer godt med hva en ville forvente.

\footnotetext{
organisasjonsstruktur eller profesjonalisering, mens alle personnavn er kodet som privatperson. Det er usikkert hvilke implikasjoner dette har for omfanget av organisasjoner i materialet. Det kan være snakk om privatpersoner som søker på vegne av en organisasjon, men som dermed blir kodet som privatperson, og det kan være oppgitt et organisasjonsnavn som gir grunnlag for koding som organisasjon, men der dette mer har karakter av å være et formål eller slagord enn en organisasjon i egentlig forstand. Omfanget av det første vet vi lite om, mens vi vil karakterisere omfanget av det siste som relativt lite. I de fleste tilfellene er det tydelige organisasjoner som står bak søknadene.
} 


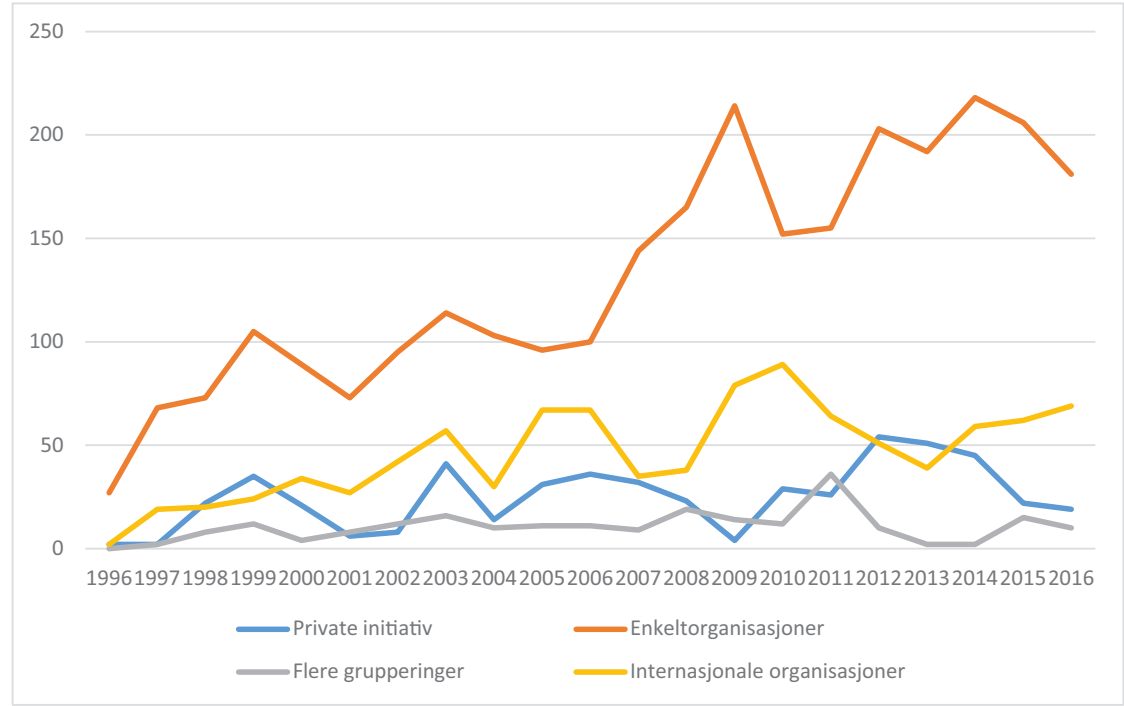

Figur 2.1: Markeringer foran Stortinget - hvem står bak?

Data: Register over markeringer på Eidsvolls plass 1996-2016

Hvilken type organisasjoner er det som tar i bruk aksjonskanalen på denne måten? ICNPO-klassifiseringen er bygd opp med en hovedinndeling der det skilles mellom 12 organisasjonskategorier, og en underinndeling innenfor hver av disse kategoriene. De 12 hovedkategoriene som det opereres med, er (1) Kultur og rekreasjon, (2) Utdanning og forskning, (3) Helse, (4) Sosiale tjenester, (5) Natur- og miljøvern, (6) Bolig og lokalmiljø, (7) Politiske- og interesseorganisasjoner, (8) Legater og fremme av frivillighet, (9) Internasjonale organisasjoner, (10) Tros- og livssynsorganisasjoner, (11) Yrkes-, bransje- og fagforeninger og (12) Andre.

Som man kunne forvente, er det i de aller fleste tilfellene snakk om politiske organisasjoner og interesseorganisasjoner som avholder markeringer utenfor Stortinget (59 prosent), noe som understreker dette som en arena for politisk ytring og påvirkningsarbeid. I tillegg til denne dominerende gruppen av organisasjoner er også tros- og livssynsorganisasjoner (14 prosent), miljø- og naturvernorganisasjoner (9 prosent) og yrkes-, bransje- og fagforeninger (8 prosent) godt representert innenfor aksjonskanalen (Figur 2.2). Mens de to sistnevnte her er som forventet, er det overraskende at en såpass stor andel av organisasjonene som er aktive på denne arenaen, befinner seg innenfor tros- og livssynsfeltet. 
Dette indikerer at plassen foran Stortinget antakelig i like stor grad er en arena der aktiviteten er rettet utover, mot forbipasserende publikum, som en arena der aktiviteten er rettet innover, mot de politiske makthaverne.

Om vi ser nærmere på de politiske organisasjonene og interesseorganisasjonene, så opererer ICNPO-klassifiseringen med tre underkategorier: «Interesseorganisasjoner», «Juridisk rådgivning» og «Politiske organisasjoner». Under Interesseorganisasjoner skilles det videre mellom «Organisasjoner for personer med nedsatt funksjonsevne og syke», «Rettighets- og støttearbeid», «Organisasjoner som arbeider for samfunnsendring» og «Organisasjoner for innvandrere og etniske grupper». Vi finner svært mange organisasjoner som, gitt denne inndelingen, klassifiseres som interesseorganisasjoner, og særlig gjelder det organisasjoner som driver med rettighets- og støttearbeid (slike ting som ytringsfrihet, menneskerettigheter, likestilling eller rettigheter for innsatte, fattige, bostedsløse, papirløse eller rusmisbrukere) (20 \%) samt organisasjoner for innvandrere og etniske grupper $(11 \%) .{ }^{12}$ Det som i klassifikasjonsskjemaet er kategorisert som politiske organisasjoner (f.eks. politiske partier), er også godt representert på Eidsvolls plass (8 \%).

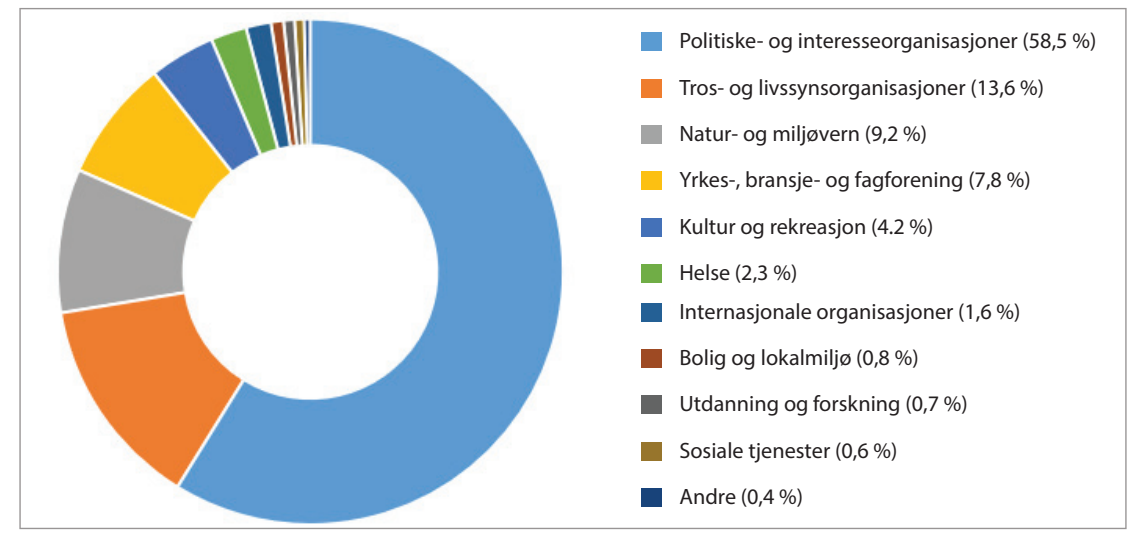

Figur 2.2: Hvilken type organisasjon står bak markeringene?

Data: Register over markeringer på Eidsvolls plass 1996-2016

12 Organisasjoner som arbeider for etniske grupper i andre land, som Palestinakomiteen eller Med Israel for fred, er her klassifisert som Rettighets- eller støttearbeid, mens organisasjoner som arbeider for innvandrere og etniske grupper i Norge, er klassifisert som Organisasjoner for innvandrere og etniske grupper. Rene kulturorganisasjoner som arbeider for å bevare en etnisk gruppes kultur og tradisjon, faller inn under Kunst- og kultur. 
Hvis vi går mer konkret inn i materialet og ser på hvilke organisasjoner det er som utmerker seg som særlig aktive på denne arenaen, er det tre typer organisasjoner som trer frem. Det er for det første religiøse grupperinger, som blant annet benytter Eidsvolls plass til forkynnervirksomhet og torgmøter, for det andre innvandrerorganisasjoner (diaspora), der markeringene ofte handler om situasjonen i hjemlandet, og, til slutt, mer tradisjonelle norske organisasjoner, særlig innenfor rettighetsarbeid eller miljø- og dyrevern.

Det er spesielt én organisasjon som klart utmerker seg i materialet, og det er Menigheten Pilgrimsfolket. Denne organisasjonen, som karakteriserer seg selv som «en fri, uregistrert og evangelisk menighet» (Pilgrimsfolket, 2018a), har holdt mer enn 170 markeringer utenfor Stortinget i den perioden vi ser på, og mye tyder på at dette først og fremst inngår som en del av foreningens forkynnervirksomhet (evangelisasjon). Foreningen skriver blant annet følgende på hjemmesiden sin: «Vi ønsker på mange måter å nå ut til mennesker med det glade budskap. Blant annet pleier vi å ha torgmøter. Da tar vi med instrumenter og høyttalere, og synger og vitner om Jesus. Vi får mulighet å samtale med mennesker, og det knyttes ofte nye kontakter» (Pilgrimsfolket, 2018b). En annen gruppering innenfor samme segment er Jesus Revolution, en organisasjon med røtter tilbake til Jesus-bevegelsen på 1970-tallet og som spesielt driver forkynnervirksomhet rettet mot ungdom. Denne organisasjonen har holdt om lag 90 markeringer foran Stortinget i perioden vi ser på, mens Jesus Church, som også retter forkynnerarbeidet sitt spesielt mot ungdom, har holdt om lag 50 markeringer. I tillegg til disse evangeliske retningene finner vi at nyreligiøse buddhistisk-inspirerte trosretninger, som Foreningen for Falun Dafa og Foreningen for Falun Gong, er svært aktive. Materialet sier lite om hva markeringene holdt av disse gruppene dreier seg om (i hovedsak klassifisert som «stand»). Norsk forening for Falun Dafa har imidlertid lenge vært engasjert i arbeidet for å stoppe den brutale forfølgelsen av personer som praktiserer Falun Gong i Kina, så det er nærliggende å anta at det her handler om politisk mer enn religiøst påvirkningsarbeid.

I den andre hovedgruppen av organisasjoner, innvandrerorganisasjonene, er det også enkelte organisasjoner som klart utmerker seg. Det 
gjelder særlig Foreningen for beboere og pårørende i Ashraf (Irak), som har holdt mer enn 180 markeringer i perioden. Generelt utmerker både det iranske og det irakiske miljøet i Norge seg, ikke bare med et stort antall aksjoner og markeringer, men også med et vell av ulike organisasjoner og grupperinger. Blant de mest aktive aktørene på Eidsvolls plass finner vi Den iranske flyktningeforeningen i Norge, Den iranske akademikerens forbund, Det iranske konstitusjonelle parti, Irakiske opposisjoner i Norge, Irans arbeider-kommunistiske parti, Iransk konverterte, Iransolidarity og Solidarisk bevegelse for demokrati og frihet i Iran, i tillegg til ulike kurdiske grupper, som Free life party of Kurdistan og Kurdistan Kulturforening. Av andre innvandrergrupper finner vi både det tamilske og det afghanske miljøet godt representert med markeringer av ulike slag. Dette bildet av at ulike innvandrergrupper er svært aktive på denne arenaen, samsvarer også med det Strømsnes og Selle (2014) finner i sin studie. Det internasjonale engasjementet har hele tiden vært en viktig del av det som skjer i aksjonskanalen i Norge, men et sentralt utviklingstrekk er at ulike innvandrergrupper i større grad har tatt i bruk aksjonskanalen for å protestere mot forhold i hjemlandet. Dette er et tydelig trekk også i det materialet vi ser på her.

Av de mer tradisjonelle norske organisasjonene utmerker NOAH - for dyrs rettigheter seg, med nesten 100 markeringer i perioden, og Natur og Ungdom, med rundt 70 markeringer. Også organisasjoner som Besteforeldrenes klimaaksjon, Bestemødre for fred, Amnesty International, Redd Barna og PRESS - Redd Barna Ungdom har et høyt aktivitetsnivå. Som vi kunne se ut fra Figur 2.2, finner vi imidlertid et vidt spenn av organisasjoner representert også innenfor kultur- og rekreasjon, utdanning og forskning, helse og sosiale tjenester samt bolig og lokalmiljø. Det er her snakk om organisasjoner som man kanskje ikke i første omgang ville forventet var særlig aktive innenfor aksjonskanalen, i alle fall ikke om man har en strikt forståelse av politiske aksjoner som protest. Dette forteller også noe om den statusen politiske aksjoner og markeringer har i Norge, som en kanal for politisk ytring som er åpen og tilgjengelig for de fleste grupperinger, og som også blir benyttet av svært ulike grupper og interesser i samfunnet til å formidle hva de står for, og til å rekruttere støttespillere til arbeidet sitt. 
De aller fleste markeringer utenfor stortingsbygningen er av Stortinget klassifisert som «Markering eller arrangement» (75\%) eller «Stand» (8\%). Dette må ses på som rolige og lite konfliktfulle markeringer, der hovedhensikten er å spre et budskap. Bare om lag 14 prosent av markeringene er klassifisert som enten en demonstrasjon, en punktdemonstrasjon / streik / sultestreik, et demonstrasjonstog eller en lys-, fakkeltog eller fanemarkering. Det er ikke noe tydelig mønster i hvilke markeringer det står organiserte interesser bak, og hvilke som er arrangert av enkeltpersoner og uformelle nettverk. Når det er snakk om demonstrasjonstog, er det imidlertid ofte flere grupperinger som står bak, mens internasjonale organisasjoner utmerker seg når det gjelder punktdemonstrasjoner, streik eller sultestreik. Vi skal ved hjelp av det andre datamaterialet vårt se nærmere på de ulike formene for politisk protest.

\section{Hvem står bak de politiske aksjonene, og hvilken aksjonsform bruker de?}

Det andre datamaterialet, som omhandler politiske demonstrasjoner omtalt i Aftenposten eller VG i perioden 1983-2015, inkluderer både lovlige og ulovlige aksjoner, aksjoner som er rettet ikke bare mot Stortinget, men også mot andre politiske institusjoner, og aksjoner både i Oslo og andre steder i landet. Er det det samme bildet som viser seg her?

Når vi ser på hvilke aktører det er som står bak aksjonene, finner vi et noe større innslag av private initiativ og uformelle nettverk i dette materialet enn når utgangspunktet var Stortingets brevjournal. Dette er ikke så unaturlig, siden materialet med utgangspunkt i Stortingets brevjournal er bygd opp med utgangspunkt i en søknadsprosess. I tillegg er det ofte slik at media ikke gir nøyaktig informasjon om hvilke organisasjoner eller aktører som står bak når de skriver om politiske aksjoner. Eksempelvis vil det i avismaterialet ofte stå at «En gruppe iranere demonstrerte ...», uten å angi hvilken konkret organisasjon det er snakk om, og det blir dermed kodet som en uformell gruppe. Vi finner likevel også i dette materialet at det står organisasjoner bak en betydelig andel av aksjonene. I 38 prosent av tilfellene har vi registrert at det er en nasjonal organisasjon som står bak initiativet, i 18 prosent av tilfellene at det er flere 
organisasjoner som står bak, mens det i 3 prosent av tilfellene er snakk om internasjonale organisasjoner, inkludert norske underavdelinger av slike. I 41 prosent av tilfellene har aktørene som står bak, blitt klassifisert som et uformelt nettverk eller privat initiativ. Dette materialet gir dermed i større grad et bilde av at det som skjer innenfor aksjonskanalen, er bygd opp rundt løsere organiserte aksjonsgrupper. Det er også oftere registrert «flere grupperinger» i dette materialet, mens det sjeldnere er snakk om internasjonale organisasjoner. Det er uansett verdt å merke seg at det for 59 prosent av aksjonene er registrert at det er en eller flere organisasjoner som står bak.

Også i dette materialet er det, naturlig nok, politiske organisasjoner og interesseorganisasjoner som dominerer når det er snakk om organisasjoner. Av de 825 hendelsene der det har vært mulig å klassifisere organisasjonen som står bak, faller 59 prosent innenfor denne kategorien (samme andel som i Stortings-materialet). Vi finner også mange innenfor kategoriene Yrkes-, bransje- og fagforening og Miljø- og naturvern (begge 16 prosent), mens Tros- og livssynsorganisasjonene ikke er like markante i dette materialet som i Stortings-materialet (3 prosent, på samme nivå som Utdanning og forskning og Internasjonale organisasjoner). Som eksempler på særlig aktive grupperinger innenfor aksjonskanalen slik det fremstår i dette materialet, kan nevnes Blitz, Natur og Ungdom og Greenpeace.

Imidlertid finner vi også i dette materialet et svært stort spenn av organisasjoner. På samme måte er spennet av tematikker stort, og også her finner vi at aksjonskanalen ikke bare brukes til å gi uttrykk for protest, men i minst like stor grad til å formidle et mer allment standpunkt til politikere og publikum. Det aksjoneres både i tilknytning til større internasjonale politiske hendelser og mindre lokale politiske saker, der fordelingen er omtrent lik mellom lokale/regionale, nasjonale og internasjonale spørsmål (henholdsvis 34, 36 og 30 prosent). Når vi skiller mellom aksjoner som det står organiserte grupper bak, og aksjoner som er basert på uformelle grupper og private initiativ, finner vi at de typiske problematikkene der organiserte grupper dominerer, er spørsmål som handler om tariff, arbeidsmiljø og arbeidsvilkår, samt miljø- og vernesaker, noe som speiler at organisasjonene innenfor disse områdene er svært aktive innenfor 
aksjonskanalen. Når demonstrasjonene omhandler tema knyttet til tariff, arbeidsmiljø og arbeidsvilkår, samt miljø- og vernesaker, finner vi at det langt sjeldnere er uorganiserte grupper og private initiativ som står bak. På den andre siden er det vanligere å finne uformelle grupper og private initiativ bak aksjoner som handler om skoletilbud, bedriftsnedleggelser eller nedleggelse av sykehus og aldershjem, altså protester knyttet til opplevde endringer og utfordringer i lokalsamfunn rundt i landet. Det er også generelt slik at de uorganiserte initiativene langt oftere handler om lokal problematikk, mens det oftere er organiserte interesser som står bak når det er snakk om nasjonale og internasjonale problemområder. Demonstrasjoner gjennomført med utgangspunkt i private initiativ og uformelle nettverk handler i 45 prosent av tilfellene om lokale eller regionale spørsmål, i 30 prosent av tilfellene om nasjonale spørsmål og i 25 prosent av tilfellene om internasjonale spørsmål. Til sammenligning handler demonstrasjoner gjennomført av enkeltorganisasjoner eller grupper av organisasjoner i 26 prosent av tilfellene om lokale eller regionale saker, i 40 prosent av tilfellene om nasjonale spørsmål og i 34 prosent av tilfellene om internasjonale spørsmål.

I tillegg til å være mer lokalt orientert er aksjonene basert på uformelle grupper og private initiativ ofte mindre omfattende målt i antall deltakere. Når vi skiller mellom aksjoner der antallet deltakere enten beskrives eller tallfestes som «få (1-10), «noen» (10-100), «relativt mange» (100-1000), «omfattende» (1000-10 ooo) eller «svært omfattende» (10 ooo + ), ser vi tydelig hvordan de mest omfattende aksjonene i større grad enn de som er mindre omfattende, er koblet til et organisasjonsapparat (Figur 2.3). Vi ser også at de fleste organisasjoner i Norge enten er relativt små, med mellom 10 og 100 deltakere, eller med relativt mange (mellom 100 og 1000) deltakere. Demonstrasjoner med mer enn 1000 deltakere er sjelden.

Den absolutt vanligste formen for politisk aksjon i Norge er punktdemonstrasjonen; en kortvarig markering som skjer på et bestemt sted og på et bestemt tidspunkt. Hele 57 prosent av hendelsene som er registrert, har form av å være en punktdemonstrasjon. Den typiske punktdemonstrasjonen gjenspeiles også i virkemidler som plakater, bannere, slagord, taler og appeller (90\% av alle aksjonene inneholder denne typen virkemidler). 


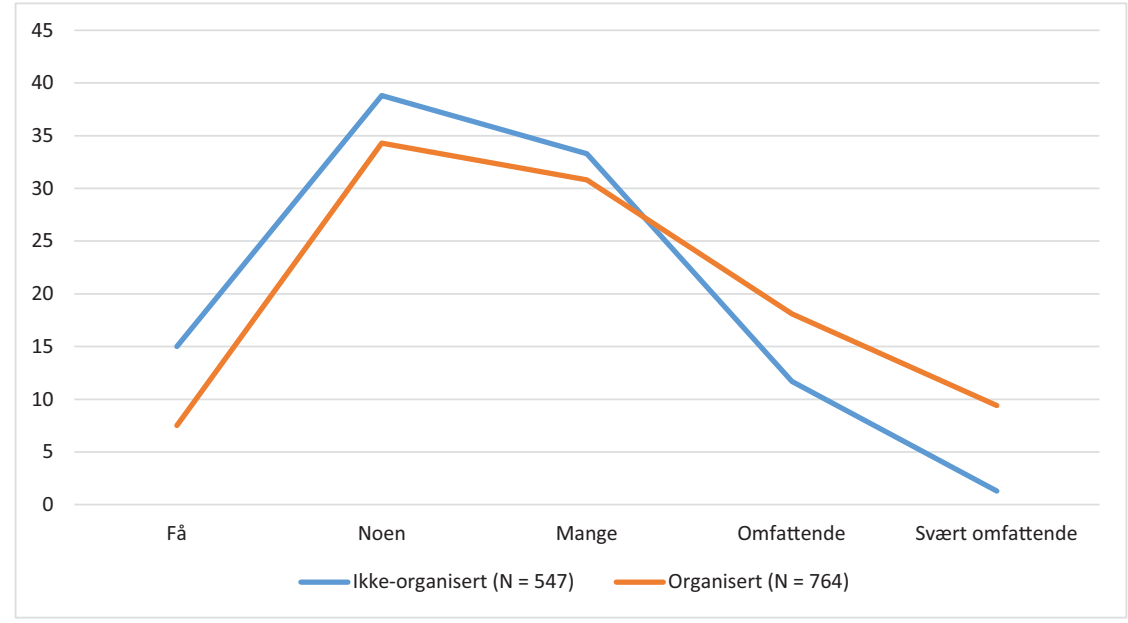

Figur 2.3: Antall deltakere, prosent

Data: Demonstrasjoner omtalt i Aftenposten eller VG, 1983-2015

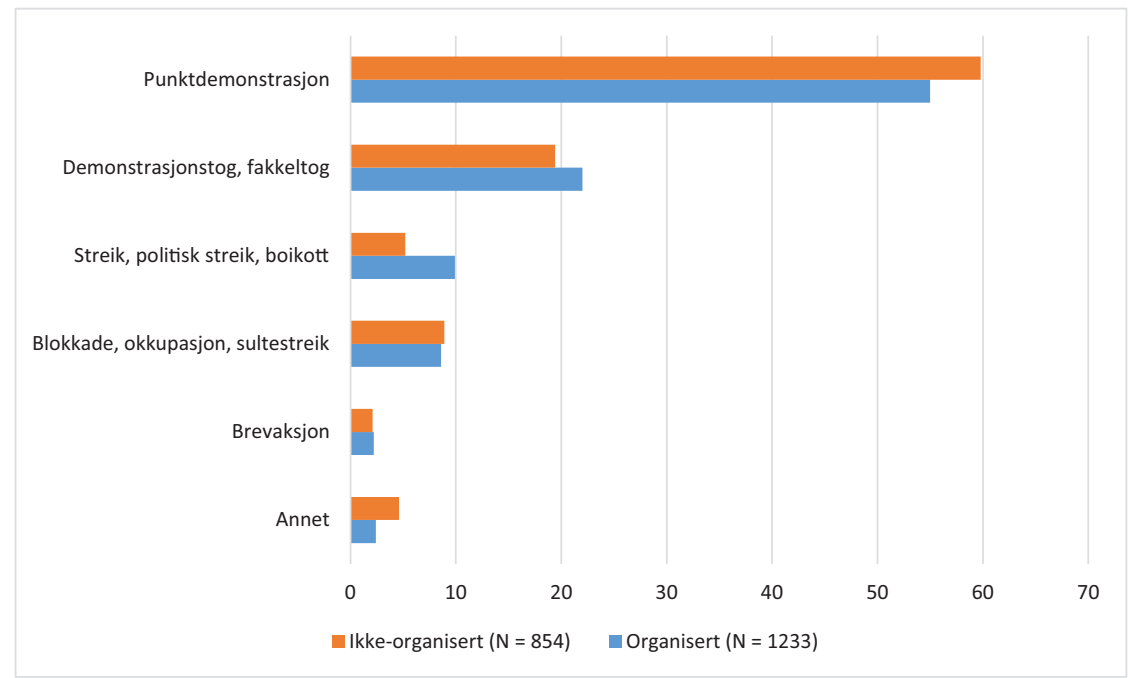

Figur 2.4: Valg av aksjonsform - organisert/uorganisert

Data: Demonstrasjoner omtalt i Aftenposten eller VG, 1983-2015

Punktdemonstrasjonen er en aksjonsform som benyttes noe oftere av uformelle grupper og nettverk enn av organiserte grupper (Figur 2.4). Derimot er demonstrasjonstog og fakkeltog samt streik, politisk streik og boikott aksjonsformer som krever en noe større grad av organisering, og det er vanligere her at det er organiserte grupper som står bak 
aksjonene. Alt i alt er det imidlertid snakk om små forskjeller. Når det gjelder de mer ytterliggående virkemidlene og hendelser på grensen til sivil ulydighet, som blokade, okkupasjon og sultestreik, er det likt fordelt mellom organiserte og uorganiserte initiativ. Også når vi ser på forskjeller i intensitet og voldsbruk, er det små forskjeller mellom aksjoner som det står organiserte grupper bak, og aksjoner initiert av uformelle grupper og private initiativ, og vi finner lite støtte for hypotesen om at organisasjoner spiller en modererende og konfliktdempende rolle innenfor aksjonskanalen. Dette er kanskje heller ikke så rart når vi tar i betraktning noen av de organisasjonene som har vært mest aktive innenfor aksjonskanalen i perioden vi ser på.

\section{Oppsummering og diskusjon}

I dette kapitlet har vi diskutert organisasjonenes rolle i aksjonskanalen i Norge ut fra to originale datasett. Begge datasettene er bygd opp med utgangspunkt i protesthendelser, og vi har i analysen spesielt vært opptatt av hvilke aktører det er som står bak disse hendelsene, og på hvilken måte de tar aksjonskanalen i bruk. Vi finner at omfanget av politiske markeringer og aksjoner i Norge er høyt, og det er også en relativt høy andel nordmenn som sier at de har deltatt i demonstrasjoner. Norge er altså ikke bare kjennetegnet av en omfattende frivillig sektor, men også av omfattende aktivitet innenfor aksjonskanalen. Som vi har vist i dette kapitlet, er det ikke slik at de to kanalene opererer frikoblet fra hverandre.

Mens materialet basert på Stortingets brevjournal gir inntrykk av at det i hovedsak er organisasjoner som står bak politiske markeringer og aksjoner i Norge, viser materialet basert på mediedekning et større innslag av uformelle nettverk og private initiativ. Sannheten ligger trolig et sted midt imellom, ettersom det i Stortings-materialet antakelig er en tendens til at omfanget av organisasjoner overrapporteres, og det i mediematerialet er en tendens til at omfanget av organisasjoner underrapporteres. Hovedinntrykket er likevel at bare en begrenset del av det som foregår innenfor aksjonskanalen, fremstår som uorganisert og spontant, og at planlegging, tilrettelegging og gjennomføring av aksjoner og markeringer i de fleste tilfeller krever organisatoriske ressurser. Uavhengig av om 
det er organisasjoner eller private initiativ som står bak aksjonene, ser de også i stor grad ut til å bruke samme «regelbok», der det raskt bygges opp et apparat som fordeler oppgaver. En komité danner ofte grunnlaget for selve aksjonen, der alt fra paroler, pressekontakt, samarbeidspartnere og virkemidler blir diskutert og vedtatt.

Organisasjonene spiller flere roller i gjennomføringen av aksjoner. I enkelte tilfeller er de aktive planleggere og organisatorer, i andre tilfeller fungerer de som informasjonshub for individuelle initiativ, der organisasjonenes ressurser og nettverk brukes til å skape et forum for interaksjon mellom aktørene. Organisasjonenes tyngde legges dessuten til en aksjon gjennom offentlig støtte til et initiativ i media. Det er heller ikke helt uvanlig at det er private initiativ og uformelle nettverk som starter en aksjon, som deretter blir tilknyttet eller kooptert av en organisasjon eller utvikler seg mot å selv bli en organisasjon. Refugees Welcome, som diskuteres i kapittel 6 i denne boken, er et eksempel på dette.

Når det gjelder organisasjonene som er aktive på aksjonsarenaen, finner vi disse innenfor en rekke organisasjonsfelt, alt fra trossamfunn og innvandrerorganisasjoner til fagforeninger og miljøvernorganisasjoner. Vi finner kontroversielle grupper, grupper i opposisjon til det bestående og grupper i konflikt med hverandre, men vi finner også et bredt spekter av ulike typer sivilsamfunnsorganisasjoner. For organisasjonene er aksjonskanalen en arena der de kan synliggjøre arbeidet sitt, spre informasjon om hva de står for, og rekrutterer nye støttespillere, uten at det er noe som går på bekostning av deltakelse i ulike korporative ordninger. Vi har ikke sett en utvikling der organisasjonene har blitt mindre viktige over tid, snarere er det tvert imot. Ulike organiserte interesser ser i økende grad ut til å stå bak de politiske aksjonene og markeringene, i alle fall når vi ser på markeringene som Stortinget har gitt tillatelse til. Dette kan antyde en utvikling i retning av et «bevegelsessamfunn». Det er snakk om et åpent politisk system som ikke bare tillater aksjoner, men som sågar åpent inviterer til det. Mulighetsrommet organisasjonene har til å benytte seg av aksjonskanalen er med andre ord stort.

Vi har også sett hvordan plassen foran Stortinget ikke bare er et sted for politiske aksjoner, men også for informasjonsspredning og meningsytring i bred forstand. Dette blir ikke minst illustrert ved et betydelig 
innslag av tros- og livssynsorganisasjoner som markerer seg foran Stortinget, og som velger nettopp denne arenaen for å gi uttrykk for budskapet sitt. Vi fant også et stort omfang og et bredt spenn av innvandrerorganisasjoner som engasjerer seg i aksjonskanalen, og ikke minst i spørsmål som omhandler situasjonen i eget hjemland. Generelt sett ser det også ut som om ulike internasjonale organisasjoner har blitt viktigere over tid.

Ikke bare er det et vidt spekter av organisasjoner representert, det er også en rekke aksjonsformer og virkemidler som tas i bruk, selv om det aller meste av det som skjer i aksjonskanalen, går fredelig for seg, og det bare i sjeldne tilfeller er snakk om voldsbruk. Dette er tilfellet både for aksjoner som det står organiserte interesser bak, og aksjoner med utspring i uformelle grupper og private initiativ. Oftere er det organiserte grupper som står bak de mer omfattende aksjonene, mens enkle punktdemonstrasjoner og aksjoner der det er færre aktører involvert, krever mindre grad av organisering. Der det er uformelle grupper og private initiativ som står bak, handler det også oftere om lokale saker, som skoletilbud og nedleggelse av sykehus og aldershjem, og disse aksjonene er oftere mindre målt i antall deltakere. Vi ser igjen hvordan aksjonskanalen ikke bare handler om protest, men fungerer som kanal for å løfte sivilt engasjement knyttet til lokale problemer opp på et nasjonalt politisk nivå, og der det er åpent for at både uorganiserte og organiserte grupper skal få slippe til med budskapet sitt.

\section{Referanser}

Allern, S. (2001). Nyhetsverdier. Om markedsorientering og journalistikk i ti norske aviser. Oslo: Høyskoleforlaget.

Barnes, S. H., \& M. Kaase mfl. (1979). Political Action: Mass Participation in Five Western Democracies. Beverly Hill: Sage Publications.

Bennett, W. L., \& A. Segerberg (2013). The Logic of Connective Action. Digital Media and the Personalization of Contentious Politics. Cambridge: Cambridge University Press.

Bjereld, U., \& M. Demker (2018). 1968 - När allt började. Stockholm: Hjalmarson \& Högberg.

Cheng, E. W. (2016). Street Politics in a Hybrid Regime: The Diffusion of Political Activism in Post-colonial Hong Kong. The China Quarterly, vol. 226, s. 383-406. 
Dalton, R. (2006). Citizen Politics: Public Opinion and Political Parties in Advanced Industrial Democracies California: CQ Press.

della Porta, D., \& Mario Diani (2006). Social Movements. An Introduction. 2. ed. Malden: Blackwell Publishing.

della Porta, D., L. Mosca \& L. Parks (2015). 2011: Subterranean Politics and Visible Protest on Social Justice in Italy. I M. Kaldor \& S. Selchow (Red.) Subterranean Politics in Europe. London: Palgrave Macmillan, s. 60-93.

Deel, S., \& T. Murray-Leach (2015). Political Blockage and the Absence of Europe: Subterranean Politics in London. I M. Kaldor \& S. Selchow (Red.) Subterranean Politics in Europe. London: Palgrave Macmillan, s. 168-199.

Earl, J., A. Martin, J. D. McCarthy \& S. A. Soule (2004). The Use of Newspaper Data in the Study of Collective Action. Annual Review of Sociology, vol. 30, s. 65-80.

Eisinger, P. K. (1973). The Conditions of Protest Behavior in American Cities. The American Political Science Review, 67(1), 11-28.

Eliasoph, N. (2013). The Politics of Volunteering. Cambridge: Polity Press.

Enjolras, B., \& K. Strømsnes (2018). The Transformation of the Scandinavian Voluntary Sector. I B. Enjolras \& K. Strømsnes (Red.), Scandinavian Civil Society and Social Transformations: The Case of Norway. Cham: Springer.

European Social Survey (2018). Politics, 2002-2016. http://nesstar.ess.nsd.uib.no/ webview/, sist lest 21.09.2018.

Fitzgerald, S. T., \& R. Spohn (2005). Pulpits and Platforms: The Role of the Church in Determining Protest among Black Americans. Social Forces, 84(2), $1015-1048$.

Francisco, R. (udatert). Protest And Coercion Data (28 European Countries from 1980 through 1995). http://ronfran.faculty.ku.edu/data/index.html, lest 23.2.2018.

Freeman, J., \& V. Johnson (Red.) (1999). Waves of Protest. Social Movements Since the Sixties. Lanham: Rowman \& Littlefield Publishers.

Gamson, W. A.; D. Croteau, W. Hoynes \& T. Sasson (1992). Media Images and the Social Construction of Reality. Annual Review of Sociology, vol. 18, s. 373-393.

Gerlach, L. P. (1999). The Structure of Social Movements: Environmental Activism and Its Opponents. I J. Freeman \& V. Johnson (Red.) Waves of protest. Social movements since the sixties. Lanham: Rowman and Littlefield Publishers, s. $85-98$.

Gleditsch, N.P., Å. Hartmann \& J. Naustdalslid (1971). Mardøla-aksjonen. Oslo: Institutt for fredsforskning.

Grendstad, G., P. Selle, K. Strømsnes \& Ø. Bortne (2006). Unique Environmentalism. A Comparative Perspective. New York: Springer.

Helle, I., \& T. Matos (2018). Norway 1945-2015: Contention and Democracy. I F. Mikkelsen, K. Kjeldstadli \& S. Nyzell (Red.) Popular Struggle and Democracy in Scandinavia. 170o-Present. London: Palgrave Macmillan. 
Henriksen, L.S., K. Strømsnes \& L. Svedberg (Red.) (2019). Civic Engagement in Scandinavia. Volunteering, Informal Help and Giving in Denmark, Norway and Sweden. Cham: Springer.

Henriksen, L. S., \& L. Svedberg (2010). Volunteering and Social Activism: Moving beyond the Traditional Divide. Journal of Civil Society, 6(2), 95-98.

Jenkins, J. C., \& T. V. Maher (2016). What Should We Do about Source Selection in Event Data? Challenges, Progress, and Possible Solutions. International Journal of Sociology, vol. 46, s. 42-57.

Johnson, R. A. (1999). Mobilizing the disabled. I J. Freeman \& V. Johnson (red.) Waves of Protest. Social Movements Since the Sixties. Lanham: Rowman \& Littlefield Publishers, s. 25-46.

Kielland, I. R. (2017). Natur og Ungdom. Aksjonene som endret norsk miljøkamp. Oslo: Cappelen Damm.

Kjellman, K. E. (2007). Mobilization and Protest in a Consensus Democracy: Social Movements, the State, and Political Opportunities in Norway. Dr. avhandling. Universitetet i Oslo: Institutt for sosiologi og samfunnsgeografi.

Klausen, K.K., \& P. Selle (1995). Frivillig organisering i Norden Oslo: Tano Aschehoug.

Korolczuk, E. (2016). Explaining mass protests against abortion ban in Poland: The power of connective action. Zoon Politicon, nr.7, s. 91-113.

Kriesi, H., R. Koopmans, J. W. Duyvendak \& M. Giugni (1995). New Social Movements in Western Europe. A Comparative Analysis. Minneapolis: University of Minnesota Press.

Lim, C. (2008). Social Networks and Political Participation: How Do Networks Matter? Social Forces, 87(2), 961-982.

Lindekilde, L., \& T. Olesen (2015). Politisk protest, aktivisme og sociale bevagelser. København: Hans Reitzels Forlag.

Martinez, L. M. (2005). Yes We Can: Latino Participation in Unconventional Politics. Social Forces, 84(1), 135-155.

McAdam, D. (1986). Recruitment to High-Risk Activism-The Case of Freedom Summer. American Journal of Sociology, 92(1), 64-90.

McAdam, D., \& R. Paulsen (1993). Specifying the Relationship between Social Ties and Activism. American Journal of Sociology, 99(3), 640-667.

McVeigh, R., \& D. Sikkink (2001). God, Politics, and Protest: Religious Beliefs and the Legitimation of Contentious Tactics. Social Forces, 79(4), 1425-1458.

Meyer, D.S., \& S. Tarrow (Red.) (1998). Social Movement Society. Contentious Politics for a New Century. Lanham: Rowman \& Littlefield Publishers.

Mikkelsen, F. (2002). Kollektive actioner og politiske bevægelser i Danmark efter Anden Verdenskrig. I F. Mikkelsen (Red.) Bevogelser i demokrati. Foreninger og kollektive aktioner i Danmark. Aarhus: Aarhus universitetsforlag, s. 45-80. 
Norris, P. (2002). Democratic Phoenix. Reinventing Political Activism. Cambridge: Cambridge University Press.

Olsen, J.P., \& H. Sætren (1980). Aksjoner og demokrati. Bergen: Universitetsforlaget.

Parmann, G. (1980). Kampen om Alta - en trussel mot vårt demokrati? Oslo: Dreyers forlag.

Pilgrimsfolket (2018a). Fellesskapet. http://pilgrimsfolket.no/?page_id=5, lest 08.02.2018.

Pilgrimsfolket (2018b). Møter. http://pilgrimsfolket.no/?page_id=173, lest 08.02.2018.

Quaranta, M. (2017). Protest and Contentious Action. Oxford Research Encyclopedia of Politics. Oxford: Oxford University Press.

Rucht, D. (1998). The Structure and Culture of Collective Protest in Germany since 1950. I D. S. Meyer \& S. Tarrow (Red.) The Social Movement Society. Contentious Politics for a New Century. Lanham: Rowman \& Littlefield Publishers, s. 29-57.

Rucht, D., \& R. Koopmans \& F. Neidhard (Red.) (1999). Acts of Dissent. New Developments in the Study of Protest. Lanham: Rowman \& Littlefield Publishers.

Sivesind, K. H. (2012). Bruk av ICNPO-kategorier i Frivillighetsregisteret. Notat. Oslo/ Bergen: Senter for forskning på sivilsamfunn og frivillig sektor.

Somma, N. M. (2010). How do Voluntary Organizations Foster Protest? The Role of Organizational Involvement on Individual Protest Participation. The Sociological Quarterly, 51(3), 384-340.

Soule, S.A., \& J. Earl (2005). A Movement Society Evaluated: Collective Protest in the United States, 1960-1986. Mobilization, 10(3), 345-364.

Stortinget (2017). Fra sumpområde til folkets talerstol. https://www.stortinget. no/no/Hva-skjer-pa-Stortinget/Nyhetsarkiv/Hva-skjer-nyheter/2016-2017/frasumpomradet-til-folkets-talerstol/, publisert 23.05.2017.

Stortinget (2018a). Disse kanalene kan du bruke for å påvirke politikken. https:// www.stortinget.no/no/Stortinget-og-demokratiet/stortinget-undervisning/ videregaende-skole/deltakelse-og-pavirkning/, lest 08.02.2018.

Stortinget (2018b). Gå til aksjon. https://www.stortinget.no/no/Stortinget-ogdemokratiet/stortinget-undervisning/videregaende-skole/deltakelse-ogpavirkning/Aksjoner/, sist oppdatert 02.02.2018.

Strømsnes, K. (2003). Folkets makt. Medborgerskap, demokrati, deltakelse. Oslo: Gyldendal Akademisk.

Strømsnes, K. (2018). Aksjonisme før og nå. Saktuelt, 28.05.2018.

Strømsnes, K., \& P. Selle (2014). Aksjoner i det representative demokrati. I H. M. Narud, K. Heidar \& T. Grønlie (Red.) Stortingets historie 1964-2014. Bergen: Fagbokforlaget, s. 479-504.

Togeby, L. (1989). Ens og forskellig. Groesrodsdeltagelse i Norden. Århus: Politica. Togeby, L. (1993). Grass Roots Participation in the Nordic Countries. European Journal of Political Research, vol. 24, s. 159-175. 
Verba, S., \& K. Lehman Schlozman \& H. E. Brady (1995). Voice and Equality. Civic Voluntarism in American Politics. Cambridge: Harvard University Press.

VG (2000). Avslag for nazi-marsjen. https://www.vg.no/nyheter/innenriks/ nazimarsjen-i-200o/avslag-for-nazi-marsjen/a/2629640/, publisert 11.08.200o, sist oppdatert 25.02.2003. 


\title{
Demokratisering av deltakelse gjennom sosiale medier. Sosial ulikhet i nordmenns digitale samfunnsengasjement
}

\author{
Ivar Eimhjellen \\ NORCE \\ Jørn Ljunggren \\ Universitetet i Oslo
}

\begin{abstract}
Based on representative survey-data, this chapter is concerned with analyzing the potential democratic effects of social media on civic engagement and collective action. We investigate to what degree and how social differences with regard to age, gender, educational background and geographical centrality are expressed in digital forms of civic action: information consumption and triggering of political interest, membership in political Facebook-groups, digital expression of opinions, and digital voluntary work. Previous research and theories are inconclusive with regard to increasing or decreasing social divides in digital participation, depending on the particular personal characteristic and type of digital civic action. Our analyses show that younger persons are more active than older persons in many of the participatory forms. Like many previous studies, we find a certain reproduction of classical gender differences in which men are more active than women. Education is also found to reproduce the classical differences in which more education is connected to higher levels of participation. We also find that centrality of residence differentiates activity levels in certain forms of digital civic action. On the basis of our analyses we claim that the democratic effects of digitalization on civic participation, in the form of reducing classical divides in which groups are active and which groups are passive, are limited. While digital technologies have created many new possibilities for civic action, participation and engagement is still structured by resources, personal traits and social position.
\end{abstract}

Keywords: digital divide, social media, civic engagement, collective action, democratization

Sitering av denne artikkelen: Eimhjellen, I, \& Ljunggren, J. (2018). Demokratisering av deltakelse gjennom sosiale medier. Sosial ulikhet i nordmenns digitale samfunnsengasjement. I B. Enjolras \& I. Eimhjellen (Red.), Fra kollektiv til konnektiv handling? Nye former for samfunnsengasjement og kollektiv handling i Norge (s. 63-99). Oslo: Cappelen Damm Akademisk. https://doi.org/10.23865/noasp.45.ch3 


\section{Innledning}

Et sentralt element i demokratiet handler om at folket deltar i utøvelsen av det. Det er imidlertid et veletablert faktum at det eksisterer betydelige forskjeller i folks samfunnsengasjement og i deres samfunnsdeltakelse, internasjonalt, så vel som i Norge. Når disse forskjellene skal forklares, er det særlig tre relaterte aspekter som trekkes frem. For det første er det en sammenheng med folks sosiale posisjon: De med tilgang til mye ressurser har generelt et større samfunnsengasjement og en mer omfattende samfunnsdeltakelse enn de med færre ressurser (Verba, Schlozman \& Brady, 1995; Olsen \& Sætren, 1980). For det andre henger engasjement og deltakelse sammen med tilgangen til informasjon: Dersom folk skal kunne mobiliseres til politiske handlinger, så trenger de informasjon om både politikk og samfunn, og i denne sammenheng snakkes det gjerne om medienes demokratiserende effekter (McLeod et al., 1996; McLeod, Scheufele \& Maoy, 1999). For det tredje er det ofte en sammenheng mellom samfunnsengasjement og -deltakelse og graden av innsats som kreves for å uttrykke engasjementet eller handle på bakgrunn av det: Jo mer innsats som er nødvendig, desto større blir skillene mellom de som engasjerer seg, og de som ikke gjør det (Uslaner, 2005; Uslaner \& Brown, 2005).

Selv om den voldsomme utbredelsen av internett og sosiale medier som har funnet sted de siste tiårene, i seg selv ikke har endret noe særlig på de sosiale ulikhetene i Norge, har imidlertid både informasjonstilgangen og handlingsmulighetene blitt langt større og mer mangfoldige. Et generelt poeng i litteraturen er at økt spredning av politisk og samfunnsrelevant informasjon kan føre til mobilisering av politiske handlinger, både fysiske handlinger (offline) og nå også som rene digitale (online) handlinger. Mens kapittel 4 i denne boken tar for seg forholdet mellom handlinger online og offline, skal vi her utelukkende fokusere på samfunnsengasjementet som foregår digitalt. Sentrale spørsmål blir dermed om, i hvilken grad, og i så fall hvordan, sosiale forskjeller i samfunnsengasjement kommer til uttrykk på nettopp internett og i sosiale medier. Vi skal derfor undersøke det vi kan kalle det digitale samfunnsengasjementet til nordmenn, ved å analysere data fra en spørreundersøkelse fra 2016 om nordmenns bruk av sosiale medier til sosial og politisk deltakelse. 
Mens tidligere studier hovedsakelig har konsentrert seg om å undersøke digitalt samfunnsengasjement på et overordnet nivå, vil vi her også ta høyde for at sosiale forskjeller kan variere etter innsats- og deltakelsesnivå. Vi har derfor delt analysene i nivåer som i noen grad reflekterer dette. For det første skal vi undersøke bruk av sosiale medier som informasjonskanaler for politikk- og samfunnsspørsmål, for det andre skal vi undersøke medlemskap i politiske eller samfunnsrettede Facebookgrupper, for det tredje skal vi undersøke digitale meningsytringer, mens vi til sist skal undersøke digitalt frivillig arbeid. Før analysene vil vi imidlertid redegjøre kort for tidligere forskning på feltet og ulike fortolkninger av utviklingen.

\section{Digital demokratisering eller reproduksjon av ulikhet?}

\section{Demokratisering gjennom digitalisering}

Selv om klassiske definisjoner av politisk deltakelse gjerne handler om stemmegivning (Ekman \& Amnå, 2012), er det også et langt bredere spekter av handlinger og ulike former for samfunnsengasjement som kan høre inn under begrepet om politisk deltakelse. Et hovedskille kan trekkes mellom såkalte latente og manifeste deltakelsesformer. Manifeste deltakelsesformer er handlinger som i hovedsak er rettet mot det parlamentariske system, og inkluderer gjerne handlinger som stemmegivning, kontakt med politikere, politisk aktivisme og meningsytring. Latente deltakelsesformer er på sin side mer uformelle handlinger som foregår utenfor det politiske eller parlamentariske system, og kan inkludere politisk oppmerksomhet eller interesse, nyhetskonsum, diskusjon eller meningsformidling basert på dette (Ekman \& Amnå, 2012). I begge formene vil mediene kunne spille en sentral rolle gjennom spredningen av politisk kunnskap og informasjon, men som sosiale medier også som kanal for ytringer og handlinger. Mediene kan her tenkes å kunne bidra til å utjevne kunnskapsskiller mellom ulike grupper og stimulere til politiske handlinger, og dermed ha demokratiserende effekt (McLeod et al., 1996; McLeod, Scheufele \& Maoy, 1999). 
Tidligere studier har nemlig vist at folk som er ressurssterke, deltar i større grad og på flere måter enn de som har færre ressurser (Verba, Schlozman \& Brady, 1995; Olsen \& Sætren, 1980). Den klassiske forskningen omkring formell politisk deltakelse har i generelle trekk vist at menn deltar mer enn kvinner, eldre mer enn yngre, høyt utdannete mer enn lavt utdannete, og de med høyt utdannete foreldre mer enn de med lavt utdannete foreldre. Det er spesielt eget utdanningsnivå som har blitt sett på som den viktigste forklaringsfaktoren for politisk deltakelse (Converse, 1972; Verba Nie \& Kim; 1978; Wolfinger \& Rosenstone, 1980).

De klassiske ideene om medienes demokratiserende effekt på spredning av informasjon tok imidlertid utgangspunkt i et medielandskap preget av langt færre medier og kanaler enn i dag. Med færre kanaler var det større sannsynlighet for at de som ikke var samfunns- eller politisk engasjert, ville bli eksponert for og lære om samfunns- og politisk informasjon fordi nyheter og politisk informasjon var et normalt innslag i mediene. Også de ikke-interesserte mediebrukerne kunne nås gjennom tilfeldig eksponering for nyheter. Samtidig som medielandskapet er mye mer komplekst i dag enn tidligere, har internett og sosiale medier også skapt langt flere deltakelsesmuligheter enn hva som er tilfellet for tradisjonelle medier - fremveksten av nettmedier har skapt nye offentlige arenaer og nettverksbaserte offentlige sfærer som mennesker kan samles og delta i (Boyd, 2011).

I mange områder av verden er sosiale skiller knyttet til selve tilgangen til internett - såkalte digital divides - fortsatt svært aktuelle (Skaletski, Galliers, Haughton \& Soermekun, 2016; Wang \& Sun, 2013). I land som Norge er dette mindre fremtredende siden 97 prosent av befolkningen har internett-tilgang (SSB, 2016). I Norge vil digitale skiller i større grad kunne knyttes til skiller i hva internett benyttes til; hvordan det benyttes, omfanget av bruken, og hva man kan få ut av denne bruken (van Deursen \& van Dijk 2014; Büchi \& Latzer 2016). Sosiale medier har her fått en svært stor utbredelse, der 75 prosent av den norske befolkningen bruker minst ett sosialt medium (SSB, 2016). Sosiale medier skiller seg fra tidligere medier blant annet ved å kunne koble mennesker sammen i større nettverksstrukturer, potensielt hele befolkninger og samfunn. Dette har skapt en viktig infrastruktur for mobilisering og organisering 
av kollektiv handling i dag, både i form av nettverk som representerer fysiske «offline» sosiale nettverk, og gjennom nettverk og kollektive handlinger som utelukkende eksisterer digitalt. Gjennom sosiale medier kan nettverk mobiliseres og organiseres med en langt større hastighet og over større avstander enn tidligere, samtidig som mobil- og trådløs teknologi har gjort begrensningene i tid og rom mindre. Sosiale medier legger videre til rette for et mangfold av ulike former for kommunikasjon, grader av interaktivitet og ulike typer medieinnhold, slik som tekst, lyd, bilder eller video. Sosiale medier har på denne måten mange flere handlingsmuligheter enn tidligere medier (Boyd, 2011). Man kan signere underskriftskampanjer, utføre frivillig arbeid, bli med i protestgrupper og aksjoner eller bli medlem i organisasjoner gjennom sosiale medier. Man kan få tilgang til politisk informasjon og medieinnhold, man kan diskutere saker og selv dele informasjon i egne nettverk. Mennesker kan samles i grupper rundt egne tema eller interesser og kommunisere og diskutere med hverandre. Mulighetene for enkeltpersoner til å engasjere seg politisk og sosialt og til å delta i, eller selv mobilisere til, kollektive handlinger har altså økt ved hjelp av sosiale medier.

Med fremveksten av disse digitale formene for samfunnsengasjement har det også fulgt med forventninger om, og potensialer for, en demokratisering av samfunnsengasjement - at flere og nye grupper av mennesker vil kunne engasjere seg sosialt og politisk. Slike forventninger er gjerne knyttet til potensialet for informasjonsspredning og mobilisering til engasjement i sosiale medier. Økt tilgang på informasjon gjennom de digitale nettverkene tenkes her å kunne spre kunnskap om politikk og samfunn på nye måter og til nye grupper, noe som igjen kan mobilisere til handling. En bekymring knyttet til dette er likevel at endringen av medielandskapet har ført til at de som er lite interessert i informasjon om politikk og samfunnsspørsmål, nå i større grad kan «unngå» å bli eksponert for dette, slik de tidligere kunne bli i tradisjonelle medier. En amerikansk studie har likevel funnet at omtrent halvparten av Facebook-brukerne i USA får nyhetene som de konsumerer, gjennom Facebook, og de fleste blir eksponert for disse nyhetene på mer eller mindre tilfeldig vis uten selv å søke etter dem - de blir eksponert for nyheter ved hjelp av sine kontakter på Facebook (deSilver, 2014). På denne måten kan 
sosiale mediebrukere på mer eller mindre tilfeldig vis bli eksponert for informasjon som potensielt kan ha en mobiliserende effekt på handling (Pasek et al., 2009; Tang og Lee, 2013; Xenos, Vromen, \& Loader, 2014).

Flere studier har vist at ulike medier, kanaler og formater kan ha forskjellige effekter på kunnskapsnivået til ulike grupper, der noen formater og kanaler kan fungere utjevnende på kunnskapsskiller (de Vreese \& Boomgaarden, 2006; Gil de Zuniga, Nakwon \& Valenzuela, 2012; Young, 2016). Andre studier peker også på at barrierene for nyhetstilgang i sosiale medier er blitt lavere og dermed kan ha utjevnende effekter (Trilling \& Schoenbach, 2013; Holt, Shehata, Strömbäck \& Ljungberg, 2013; Kobayashi \& Inamasu, 2015). Ved en mer tilfeldig spredning av sosiale og politiske nyheter og informasjon i sosiale medier, samt en potensiell mobilisering til handling på bakgrunn av informasjonen, kan sosiale medier dermed ha en demokratiserende effekt ved å utjevne sosiale forskjeller i samfunnsengasjement. At slik informasjon nå kan komme gjennom personlige kontakter (venner eller familie), kan potensielt gjøre den mobiliserende effekten enda større (Bode, 2012).

\section{Nytt medielandskap - tradisjonelle ulikheter}

Selv om de nye sosiale mediene har ført til et langt større tilbud av politisk og samfunnsmessig informasjon og dermed kan ha hatt en demokratiserende effekt ved å utjevne sosiale ulikheter i kunnskap og muligheter for handlinger, er det også noen faktorer som taler mot dette. For det første kan det innvendes at konsum av politisk og samfunnsrelevant medieinnhold bunner i en allerede eksisterende politisk interesse hos mottakeren. At informasjonen nå også kommer gjennom sosiale medier, har ikke endret på at dette henger sammen med sosial bakgrunn og nåværende sosial posisjon. Det finnes endog flere studier som har vist at egen motivasjon for å finne og lære fra nyheter har større innvirkning i digitale enn i tradisjonelle medier (Haight, Quan-Haase \& Corbett, 2014; Van Dijk \& Hacker, 2003; Wei \& Hindman, 2011).

Av dette følger det at de politisk interesserte vil bruke medier (både tradisjonelle og sosiale) til å konsumere politisk informasjon og til aktiv deltakelse, mens de som er mindre interessert, bruker mediene til andre 
formål, som for eksempel fritidsinteresser og underholdning. I stedet for å bidra til sosial utjevning i informasjon og deltakelse vil dette heller kunne reprodusere og forsterke allerede eksisterende sosiale og digitale skiller, der høyt utdannende, politisk kunnskapsrike og politisk interesserte får forsterket sin politiske interesse, kunnskap og deltakelse gjennom sin mediebruk, mens de mindre interesserte blir politisk "passivisert». I et slikt perspektiv vil ikke sosiale medier bidra til å styrke demokratiet, men snarere til å reprodusere og forsterke sosial ulikhet knyttet til kunnskap og samfunnsengasjement.

I en litteraturgjennomgang på feltet finner van Aelst og kolleger (2017) en rekke studier som peker på økende skiller i nyhetskonsum, i både tradisjonelle og digitale kanaler. Et stadig større tilbud av både politisk og ikke-politisk informasjon i ulike kanaler har skapt et større samsvar mellom etterspørsel etter politisk informasjon hos de politisk interesserte og etterspørsel etter ikke-politisk informasjon hos de som ikke er interessert i politikk. Her tyder flere studier på at dette fører til større kunnskapsskiller (Prior, 2007; Hollander, 2008; Wei \& Hindman, 2011).

\section{Kunnskap, innsats og handling?}

Selv om det altså ikke er noe entydig svar på om internett og sosiale medier har bidratt til økt samfunnsengasjement generelt, eller blant flere grupper enn tidligere, så er det liten tvil om at det nye medielandskapet har ført til et større tilbud av informasjon og, ikke minst, langt flere muligheter til å uttrykke eller på andre måter handle ut fra sitt samfunnsengasjement. På omtrent samme måte som vi har sett ovenfor om økt informasjon, kan man også her se for seg at økningen i handlingsmuligheter kan bidra til å utjevne sosial ulikhet i politisk deltakelse. Imidlertid vil de samme innvendingene kunne reises her - de allerede eksisterende forskjellene i politisk interesse og i ressurser vil også kunne gjøre seg gjeldende i digital politisk handling. Likevel skiller handlingsalternativene seg noe. For der informasjonen primært kommer gjennom flere kanaler, har digitaliseringen bidratt med helt nye handlingsalternativer som i mange tilfeller krever relativt liten grad av innsats. En lavere terskel for å delta vil potensielt kunne føre til at «politisk passive» lettere vil kunne 
mobiliseres til å utøve slike handlinger, siden det gjerne bare er «noen tastetrykk unna».

Men nettopp på grunn av den lave innsatsgraden finnes det også innvendinger mot å kalle noen typer digitale handlingsformer for «politiske handlinger»: Siden disse kan utføres med minimalt engasjement hos den enkelte, er det heller ikke «ekte» engasjement eller aktivisme, men «slacktivism» (Morozov, 2011). Selv om intensjonene og engasjementet bak handlingene hos den enkelte riktignok vil kunne variere, kan de likevel få politisk betydning i kraft av sine konsekvenser dersom mange nok er med. Et viktig poeng her er uansett at undersøkelser av digitalt samfunnsengasjement må ta høyde for at det også i denne formen eksisterer forskjeller i innsatsgrad, og at en derfor bestreber seg på å ta høyde for dette ved å ikke blande sammen handlinger som krever svært forskjellig nivå av innsats. Som tidligere nevnt, gjør vi et slikt forsøk her når vi deler opp analysene i fire deler.

Selv om en kan argumentere for at det krever høyere innsats å lese informasjon enn å trykke «liker» på en sak på Facebook, har vi likevel plassert bruk av samfunnsrelevant og politisk informasjon i sosiale medier på det «laveste» nivået. Grunnen til dette er for det første at konsum av slik informasjon kan foregå helt privat, men også at slikt konsum gjerne legger grunnlaget for ytterligere handlinger. En annen lavterskel digital handlingsform, og vårt andre nivå, er det å for eksempel bli med i Facebook-grupper for aksjoner eller demonstrasjoner (politisk orienterte grupper). Et enkelt trykk kan her signalisere at man støtter en sak, og man inngår som en del av medlemsmassen i gruppen. Her finnes det mange eksempler på aksjoner som har lyktes i å samle store mengder Facebook-medlemmer, og som igjen har gitt aksjonene og sakene mye oppmerksomhet. Sakene kan variere fra å få tilbake et pålegg som er forsvunnet fra butikkhyllene, til store støttegrupper for flyktninger (se Sætrang i kapittel 6). ${ }^{1}$ Når man så er med i slike grupper eller aksjoner, får man også tilgang til informasjon og til diskusjoner der man selv kan delta, og det leder oss over til vårt tredje nivå: aktiv deltakelse i politiske

1 Det er imidlertid verdt å minne om at det nok finnes et langt større antall mislykkede enn vellykkede aksjoner, der få er blitt engasjert, og som har fått lite oppmerksomhet. 
diskusjoner og meningsytringer i sosiale medier - handlingsformer som åpenbart krever mer innsats enn bare et tastetrykk. Selv om det finnes folk som bruker svært mye tid på debatt i internettfora, så har vi laget et fjerdenivå for handlingsform, som vanligvis krever enda mer innsats enn debatt og meningsytring - det vi kan kalle digitalt frivillig arbeid. Dette kan for eksempel være frivillig arbeid for eksempelvis et nettsamfunn eller diskusjonsgruppe med veiledning av nye medlemmer, moderering av diskusjoner, eller vedlikehold og utvikling av nettsider.

\section{Forventninger på bakgrunn av sosiale forskjeller og deltakelsesformer i Norge}

I dette kapitlet skal vi altså undersøke i hvilken grad det er sosiale forskjeller i samfunns- og politisk engasjement i sosiale medier, gjennom å ta for oss handlinger på fire innsatsnivåer. Som tidligere nevnt er det spesielt forskjeller knyttet til eget utdanningsnivå som fremheves som viktige i den internasjonale litteraturen. Vi vil imidlertid her også undersøke sosiale forskjeller knyttet til faktorer som ofte viser seg å være sentrale i fordelingen av en rekke samfunnsmessige goder, byrder og aktiviteter. Nærmere bestemt inkluderer vi også alder, kjønn, bostedssentralitet og foreldres utdanningsnivå. Siktemålet vårt her er å kort oppsummere den (begrensede) forskningen som finnes på feltet i Norge, for å presentere noen deskriptive forventninger. I alle tilfeller forventer vi at forskjellene vil være større jo høyere innsatsnivå.

Selv om eget utdanningsnivå er en sentral faktor i de sosiale forskjellene i tradisjonell politisk deltakelse (Verba, Schlozman \& Brady, 1995; Olsen \& Sætren, 1980), er ikke forskningen på digitale deltakelsesformer like entydig. I Norge finner Enjolras mfl. (2013) at høyt utdanningsnivå ser ut til å ha mindre betydning når det gjelder politisk og samfunnsrettet aktivitet på Facebook. Her fant forfatterne derimot en svak (men ikke signifikant) tendens til at flere med lavere utdanning var aktive i debatt på Facebook enn de med høy utdanning. Dette gjaldt også for debatt i nettavisers kommentarfelt og i andre sosiale medier som YouTube. Studien viste også at de høyest utdannede brukte mer tid på politisk stoff både i nettaviser og papiraviser, mens de som brukte mye tid til slikt stoff 
i sosiale medier, oftere hadde noe lavere utdanning (Enjolras mfl. 2013). Basert på dette forventer vi derfor å finne mindre tydelige forskjeller $\mathrm{i}$ digital politisk deltakelse med utgangspunkt i utdanningsbakgrunn. Det kan altså ha skjedd en viss form for demokratisering der utdanning i mindre grad betyr noe for digitale deltakelsesformer.

Et sentralt kjennetegn for forklaring av ulik bruk av digitale medier generelt er alder. Yngre har i all hovedsak en mer intensiv bruk både i tid og i form av flere ulike typer aktiviteter, sammenlignet med eldre, selv om aldersforskjellene etter hvert blir mindre. I en norsk undersøkelse finner for eksempel Sakariassen, Hovden og Moe (2017) at flere blant dem under 25 år enn over konsumerer nyheter gjennom sosiale medier, men at forskjellene ikke er like store på Facebook. Alder kan her se ut til å utgjøre en forskjell for nyhetskonsum i sosiale medier generelt, men ikke på Facebook spesielt. Enjolras mfl. (2013) finner imidlertid at det er flere unge enn eldre som bruker Facebook og andre sosiale medier til debatt, at flere unge har Facebook som den viktigste kanalen for nyheter, og at det er flere unge som deltar i protestgrupper på Facebook. Unge ser også ut til å ha en større sannsynlighet for å gjøre frivillig arbeid gjennom internett (Wollebæk \& Sivesind, 2010; Eimhjellen, 2018). Basert på disse funnene forventer vi at unge er mer aktive enn eldre i digitale engasjementsformer, og at vi dermed kan se en viss demokratisering ved at de unge tar $i$ bruk digitale kanaler til handlinger som tradisjonelt har vært dominert av voksne og eldre offline.

Når det gjelder kjønn og digital deltakelse, finner Enjolras mfl. (2013) at kvinner er underrepresentert som deltakere i samfunnsdebatt (om politikk og samfunn) i sosiale medier. Kjønnsforskjellen gjaldt imidlertid ikke for Facebook, der kvinner deltok i like stor grad som menn. Når det gjelder frivillig arbeid på nett, fant Wollebæk og Sivesind (2010) at menn var mer aktive enn kvinner. Basert på disse undersøkelsene forventer vi altså å finne kjønnsforskjeller i det digitale, der menn i hovedsak utviser et større samfunnsengasjement enn kvinner, men at forskjellene kanskje ikke er like synlige på Facebook.

Tradisjonelt har skillet i politisk deltakelse mellom sentrale og rurale områder blitt forstått som at nye former for både teknologi (Marvin, 1988) og politisk deltakelse først oppstår i urbane kontekster (mer heterogene, 
innovative og med avvikende sub-kulturer), for så å bli spredt til mer rurale områder (Deutsch, 1961; Fisher, 1975a, 1975b; Schnaiberg, 1971). I dagens kontekst, der spredningen av informasjons- og kommunikasjonsteknologi fra urbane sentre til mindre befolkede områder skjer stadig raskere, kan det imidlertid også tenkes at geografiske grenser er mindre viktige (Fortunati \& Taipale, 2013). Kommunikasjonsteknologien har i seg selv gjort betydningen av sted og geografisk avstand mindre relevant for spredning av informasjon, kunnskap, ideer og handlingsformer (Castells, 2009). En norsk studie av sammenhengen mellom folketall og politisk engasjement på Facebook har vist at disse ikke var spesielt fremtredende (Eimhjellen, 2014). På bakgrunn av dette forventer vi en demokratisering der geografisk bosted ikke betyr så mye for politisk deltakelse gjennom internett og sosiale medier.

I tillegg til disse forventningene om sosiale forskjeller i digital deltakelse vil vi også anta at forskjellene vil være større jo mer innsats som kreves. Med disse forventningene som utgangspunkt skal vi videre ta for oss datagrunnlaget og metodene som er brukt i analysene, før vi presenterer resultatene. Vi avslutter kapitlet med en diskusjon og lanserer noen tentative konklusjoner. De overordnede spørsmålene handler altså om i hvilken grad, og i så fall hvordan, sosiale forskjeller i samfunnsengasjement kommer til uttrykk i den digitale sfæren.

\section{Data og metode}

Analysene som gjøres i dette kapitlet, er basert på sosiale medier-undersøkelsen fra 2016. Denne er et representativt utvalg av den norske internettbefolkningen og er trukket fra Kantar TNS' internettpanel. Svarprosenten var på 44,5 prosent, og nettoutvalget bestod av 5054 respondenter. ${ }^{2}$ I det endelige datamaterialet har vi i tillegg begrenset utvalget til å kun omfatte individer som ikke er klassifisert som pensjonister. Dette er gjort av både metodiske og substansielle årsaker. For det første er pensjonister betydelig overrepresentert i det opprinnelige materialet, og selv om man kunne

2 For en oversikt over fordelingene i brutto- og nettoutvalgene, se Eimhjellen og Ljunggren (2017, s. 24). 
tenke seg å «vekte» denne skjevheten, er det gode grunner til å tro at pensjonistene i utvalget i mindre grad enn andre grupper i utvalget «ligner» på de som er i populasjonen. Primært på grunn av at dette er en nettbasert survey som omhandler nettopp nettaktivitet. ${ }^{3}$ Dette aspektet berører selvsagt også slutninger som trekkes om populasjonen i sin helhet. Bruken av internettpanel kan på generelt grunnlag medføre en risiko for at andelene av digitalt aktive overvurderes noe i en sammenligning med alle nordmenn: Utvalget er allerede "på internett». Vi vil derfor understreke at utvalget er trukket fra «internettpopulasjonen», altså fra de som i noen grad allerede benytter seg av internett, men som vi har vært inne på, gjelder dette hele 97 prosent av den norske befolkningen (SSB, 2016).

Selv om bruken av internett og sosiale medier også er sterkt økende blant pensjonister, er den fortsatt ikke blitt like omfattende og variert som i resten av befolkningen. Det er altså rimelig å anta at pensjonistene i internettpopulasjonen skiller seg mer fra pensjonister i den totale befolkningen enn hva som er tilfellet for de yngre aldersgruppene. En annen løsning kunne vært å kontrollere for pensjonister i samtlige analyser for å undersøke om disse skiller seg fra ikke-pensjonistene på andre måter enn det som synliggjøres gjennom å benytte bare alder. En rekke detaljerte tilleggsundersøkelser viser imidlertid at slike forskjeller ikke er systematiske, men varierer fra analyse til analyse. Dette ser også ut til å påvirke sammenhengene mellom den aktuelle avhengige variabelen og de andre uavhengige variablene. Substansielt sett er selvsagt også pensjonister en interessant gruppe å studere når det gjelder temaene i dette kapitlet. Imidlertid er det grunn til å tro at sosiale medier har en annen betydning for individer som er i utdanning eller arbeid. Vår vurdering er altså at analyser med pensjonistene hadde blitt så omfattende, og gjort resultatene langt mindre tolkbare, at vi ekskluderer dem fra analysene.

For å undersøke sosiale forskjeller har vi begrenset oss til et relativt standardisert sett av variabler, nemlig kjønn, alder, utdanningsnivå, foreldres utdanningsnivå og kommunesentralitet. At egen utdanning benyttes i stedet for eksempelvis yrke eller inntekt, handler for det 
førstnevnte om fravær av informasjon om dette i dataene. At utdanning er valgt fremfor inntekt, er i all hovedsak et pragmatisk valg. I en rekke tilleggsanalyser der inntekt er inkludert, er det så høy kovarians mellom disse at de i stor grad kan ses på som indikatorer for det samme fenomenet. Å benytte utdanning har imidlertid den fordelen at vi også har den samme informasjonen om respondentenes foreldre. Noe vi ikke har når det gjelder inntekt. For å lage variabelen for foreldres utdanningsnivå har vi benyttet informasjon fra spørsmål om både mors og fars utdanning og deretter konstruert «sosial bakgrunn». For å kun få én verdi har vi benyttet oss av en såkalt dominance approach (Erikson, 1984), der den forelderen med det høyeste utdanningsnivået, uavhengig av kjønn, er gitt fortrinn. Siden det var få respondenter $(n=89)$ som hadde foreldre med lengre høy utdanning ( $>4$ år), har vi slått sammen kategoriene for kortere og lengre høyere utdanning til én gruppe. For å måle bostedssentralitet har vi benyttet sentralitetsindeksen til Statistisk sentralbyrå. ${ }^{4}$ Den klassifiserer bostedskommune i fem kategorier etter hvor stor avstand det er til tettsteder av ulik størrelse.

Den analytiske fremgangsmåten består i all hovedsak av logistisk regresjonsanalyse, som, forenklet sagt, handler om å sammenligne de som «gjør noe», med de som «ikke gjør noe», ved å gjøre gruppene som sammenlignes, så like som mulig på andre relevante kjennetegn. I et tenkt eksempel vil det altså handle om å se på sammenhengen mellom for eksempel alder og det å ytre seg på internett, kontrollert for andre faktorer, som blant annet utdanningsnivå. Vi benytter imidlertid også en analyseteknikk for å kunne undersøke mange variabler samtidig og å avdekke såkalte underliggende dimensjoner, såkalt faktoranalyse, eller mer konkret «Principal component analysis», PCA (Bertholomew, Steele, Moustaki \& Galbraith, 2008), for å undersøke nærmere om det finnes noen sentrale underliggende dimensjoner som kan redegjøre for mest mulig av variansen som er til stede når vi ser på mange variabler samtidig. I stedet for å undersøke én og én variabel forsøker vi altså her å se på mange samtidig for å undersøke om det eksisterer et slags «hovedmønster» av samvariasjon mellom variablene.

4 Se: http://stabas.ssb.no/ItemsFrames.asp?ID=5285601\&Language=nb. 


\section{Analyse}

Som tidligere redegjort for har vi delt inn analysene etter ulik - og antatt $ø$ kende - grad av innsatsnivå. Bakgrunnen for dette er forventninger om at det vil være større sosiale forskjeller desto høyere innsatsnivå som kreves for å utføre handlingen.

\section{Politisk informasjon og interessestimulans}

Å lese eller motta samfunnsrelevant informasjon kan ses på som en form for samfunnsengasjement (latent politisk deltakelse - jf. Ekman \& Amnå 2012), som igjen kan stimulere til videre interesse, engasjement og andre former for frivillig eller politisk deltakelse. Selv om vi her altså klassifiserer denne typen handlinger som «lavest» innsatsnivå, er det likevel ofte slikt engasjement som ligger under de andre og mer «innsatskrevende» formene vi senere skal se på. I undersøkelsen spurte vi respondentene om de brukte tid på informasjon om samfunn og politikk i sosiale medier. 38 prosent svarte at de brukte tid på dette en gjennomsnittsdag. Når vi undersøker for forskjeller basert på de aktuelle faktorene, finner vi ingen signifikante forskjeller. Det ser altså ikke ut til å være store forskjeller i hvem det er som bruker tid på informasjon om samfunn og politikk i sosiale medier, men er det forskjeller i om denne typen informasjon vekker interesse for samfunnsrelevante spørsmål?

I undersøkelsen spurte vi respondentene om de i løpet av det siste året hadde bestemt seg for å finne ut mer om et samfunns- eller politisk spørsmål på grunn av noe de hadde lest i sosiale medier. 32 prosent svarte bekreftende på dette. Som illustrert i figur 1 var det også noen forskjeller mellom ulike grupper. Det var flere blant kvinner (33 prosent) enn blant menn (29 prosent), flere av de yngre enn av de eldre (avtagende fra 44 til 21 prosent), flere personer blant de med høyt utdannede foreldre (stigende fra 23 til 41 prosent), og flere blant personer bosatt i sentrale enn i mindre sentrale kommuner ( 34 ned til 23 prosent) som svarte ja. Fordelingen etter egen utdanning viste at det var flere blant personer med videregående/yrkesskole enn i de andre utdanningskategoriene. 


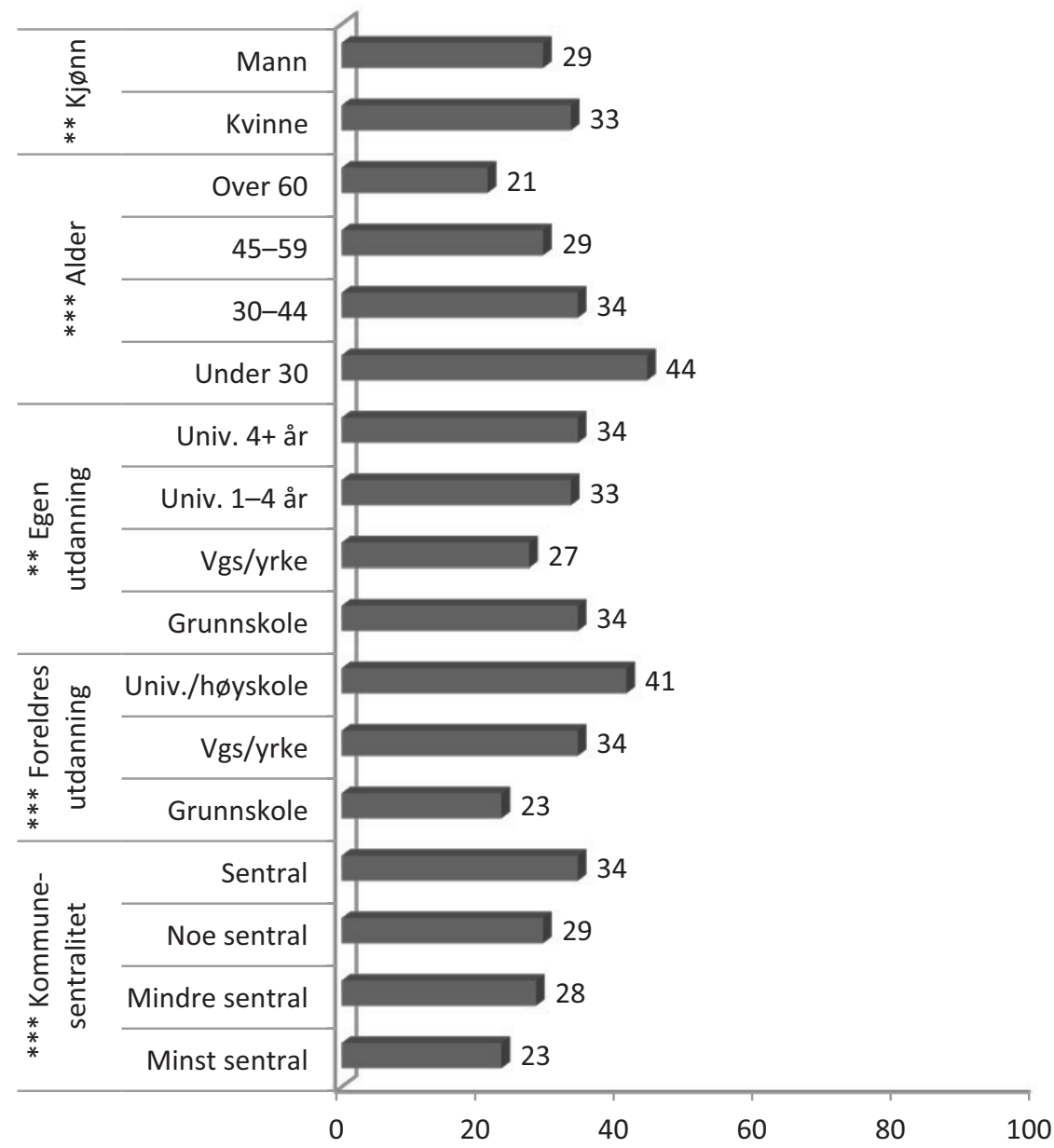

Figur 1: Ville finne ut mer om et samfunns- eller politisk spørsmål pga. av noe lest i sosiale medier. Prosent $(N=3263) .{ }^{\star \star \star} p<0.001,{ }^{\star \star} p<0.01,{ }^{\star} p<0.05$

Men når vi undersøker disse forskjellene nærmere ved å se på sammenhengene mellom de ulike kjennetegnene kontrollert for de andre faktorene i en regresjonsmodell (vist i appendikstabell 2), viser det seg at både kjønnsforskjellene og forskjellene knyttet til egen utdanning forsvinner. Forskjellene knyttet til alder, foreldres utdanning og kommunesentralitet består fortsatt. Regresjonsanalysen viser at jo yngre man er, jo høyere utdannete foreldre man har, og jo mer sentralt man bor, desto større sannsynlighet er det for at man har villet finne ut mer om et samfunnseller politisk spørsmål på grunn av noe man leste i sosiale medier. 
Samlet sett er det altså ingen sosiale forskjeller knyttet til å konsumere slik informasjon i seg selv eller i hvor mye tid som benyttes på det. Når det gjelder sosiale forskjeller i hvem som får vekket ytterligere politisk interesse gjennom slik informasjon, finnes det imidlertid noen signifikante forskjeller. Yngre blir i større grad ytterligere interessert enn eldre, de med høy sosial bakgrunn i større grad enn de med lav bakgrunn, og de som bor i mer sentrale kommuner, i større grad enn de i mer rurale kommuner. Siden det oftest har vært eldre som er mest interessert, taler aldersfaktoren her i så måte for en demokratisering, men det kan også henge sammen med ulik grad av fortrolighet med sosiale medier. Utdanningsforskjellene tyder på sin side på at forskjeller i politisk interesse i noen grad blir reprodusert i sosiale medier. At foreldrenes utdanningsnivå har en selvstendig effekt, mens egen utdanning ikke har det, kan tyde på at foreldrenes politiske interesse er overført til barna, men også at mange unge i utvalget ennå ikke har rukket å fullføre egen utdanning. Gitt forventningene er det for øvrig interessant at det ikke er signifikante kjønnsforskjeller. Dette kan handle om at Facebook, som også tidligere har hatt mindre kjønnsforskjeller, er blitt et enda mer dominerende medium siden undersøkelsen til Enjolras og kolleger (2013) ble foretatt.

\section{Medlemskap i Facebook-grupper}

Når vi så beveger oss over til det andre nivået - medlemskap i samfunnsrettede eller politiske Facebook-grupper - er også dette en lavterskel digital politisk handling som både kan signalisere støtte til en sak og gi tilgang til informasjon, men som i likhet med konsum av informasjon potensielt kan mobilisere til andre handlinger. I undersøkelsen spurte vi respondentene om de var medlem i ulike typer grupper på Facebook, og i så fall hva slags grupper. Ved hjelp av en faktoranalyse (PCA) har vi undersøkt om politisk orienterte grupper er sentrale i respondentenes gruppemedlemskap. I faktoranalysen var det tre mønstre, eller dimensjoner, som skilte seg ut: en dimensjon som samlet grupper for venner, medier, firma/ produkt, hjemsted og humor, en annen dimensjon som samlet grupper for politikere (lokale og topp-politikere) og politiske partier, og en tredje 
dimensjon som samlet medlemskap i protestgrupper (nasjonale og internasjonale). Det er altså to dimensjoner eller typer av politiske eller samfunnsrettede grupper som skiller seg ut, en som vi kan kalle institusjonell politikk, og en protestpolitikk. Litt over en tredjedel av respondentene er med i grupper for institusjonell politikk (37 prosent), mens omtrent en fjerdedel er med i grupper for protestpolitikk (26 prosent).

For medlemskap i grupper for protestpolitikk var det ingen signifikante kjønnsforskjeller. Når det gjelder alder, avtar medlemskap i protestpolitiske grupper betydelig med økende alder. Andelene er betydelig mindre for de over 60 år. Yngre personer er altså i større grad enn de eldste med i protestpolitiske grupper på Facebook. Forskjellene er små og ikke-signifikante når det gjelder eget utdanningsnivå. Men om vi ser på utdanningsnivå hos foreldre, utgjør igjen dette signifikante forskjeller for medlemskap i protestpolitiske grupper. Ved økende utdanningslengde hos foreldre er det flere som er medlemmer i protestpolitiske grupper. Til slutt henger også kommunesentralitet sammen med medlemskap i både institusjonelle og protestpolitiske grupper (signifikant på o,05-nivå). For medlemskap i Facebook-grupper for institusjonell politikk er det flest blant dem i mindre sentrale (46 prosent) og i minst sentrale (42 prosent) kommuner som er medlemmer. For protestpolitiske grupper er den høyeste andelen å finne blant personer i mindre sentrale kommuner ( 35 prosent) sammenlignet med både de minst og de mest sentrale kommunene.

Når vi til slutt undersøker utslagene av de enkelte faktorene hver for seg (se appendikstabell 3), og kontrollerer for de andre, så forsvinner mye av sammenhengen med utdanningsbakgrunn (egen og foreldres). Forskjellene som gjenstår, er at menn har større sannsynlighet for å være med i grupper for institusjonell politikk, og yngre mennesker har større sannsynlighet for å være med i protestpolitiske grupper. Jo mer sentralt man bor, desto mindre sannsynlig er det at man er med i Facebookgrupper knyttet til institusjonell politikk. Med unntak for medlemskap i protestpolitiske grupper der det er en betydelig effekt av å ha foreldre med høy utdanning, ser ikke utdanningsbakgrunn ut til ha noen signifikant sammenheng med mønstre for Facebook-gruppemedlemskap. 
Grupper for institusjonell politikk

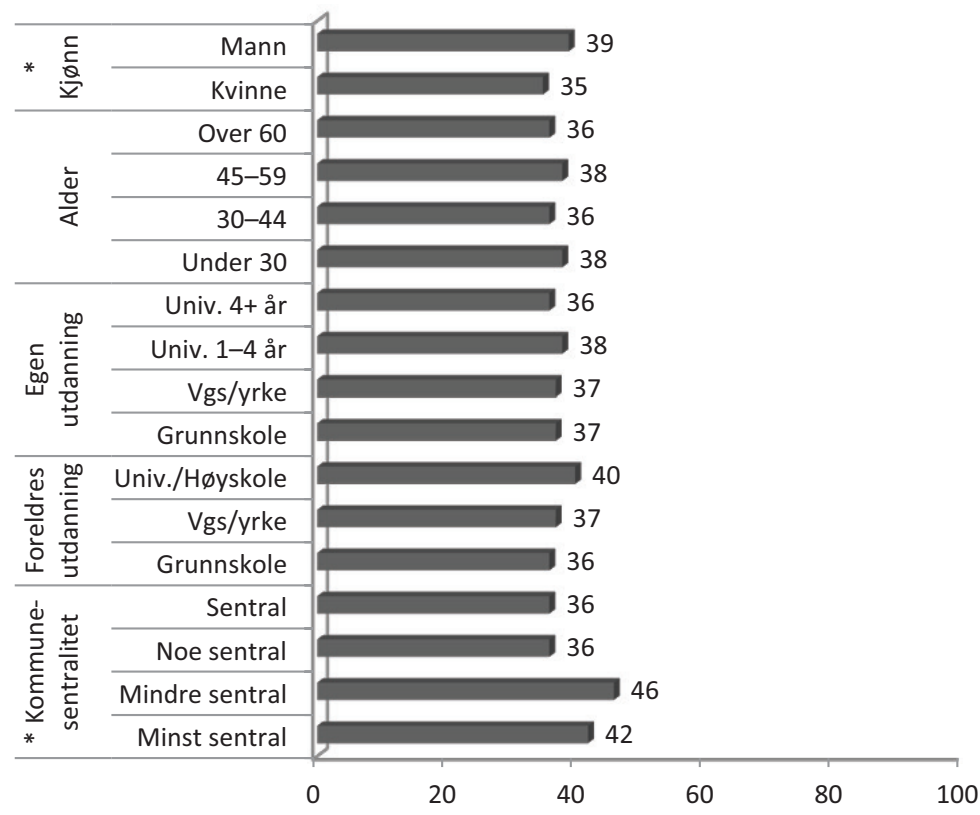

\section{Grupper for protestpolitikk}

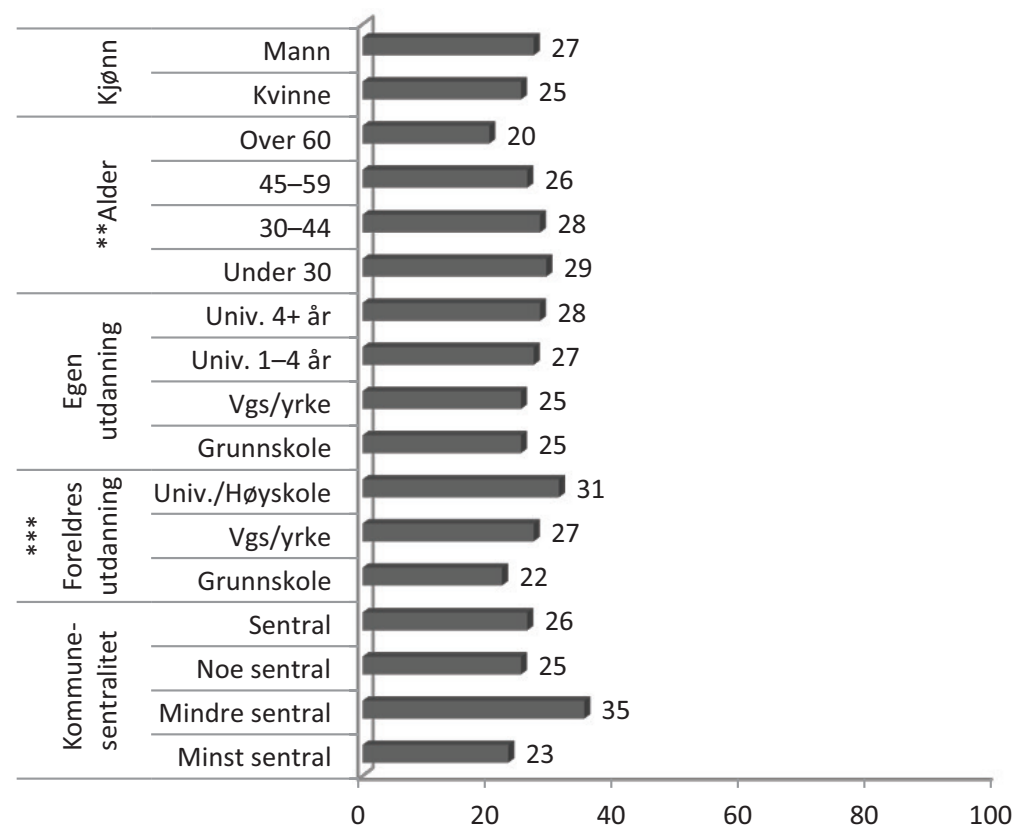

Figur 2: Medlemskap i Facebook-grupper for institusjonell politikk og protestpolitikk fordelt på bakgrunnsvariabler. Prosent (Chi.sig) (Max N = 2980). ${ }^{\star \star \star} p<0.001,{ }^{\star \star} p<0.01,{ }^{\star} p<0.05$ 


\section{Digitale meningsytringer}

En mer aktiv digital engasjementsform enn medlemskap i Facebookgrupper, og det tredje nivået vi analyserer her, er deltakelse i diskusjoner og egne meningsytringer på nett. Finner vi sosiale forskjeller i hvor, og hvor ofte, folk gir uttrykk for sine meninger og synspunkter på internett? I undersøkelsen spurte vi respondentene hvor ofte de gav uttrykk for sine meninger eller synspunkt på «internett», og sine politiske meninger og synspunkt $\mathrm{i}$ «åpne fora på internett» og $\mathrm{i}$ «lukkede grupper». Til sammen 31 prosent sier de av og til eller oftere uttrykker sine meninger eller synspunkt på internett, 39 prosent gjør det nesten aldri, og 30 prosent sier at de aldri gjør det. Når vi spør om politiske meninger og synspunkt mer spesifikt, og skiller mellom åpne og lukkede forum, er det enda færre som sier at de uttrykker seg. Til sammen 23-24 prosent gjør det ofte eller sjelden, 35-37 prosent gjør det nesten aldri og 39-40 prosent gjør det aldri. Det er altså ikke så vanlig å uttrykke sine meninger på internett, og enda mindre vanlig om vi spør om politiske meninger mer spesifikt.

Av de som har svart at de ytrer seg ofte eller av og til $i$ «lukkede grupper» (ca. 24 prosent av utvalget), det vil si på steder eller i fora som krever en eller annen form for innlogging eller registrering (slik som Facebook-grupper), fremkommer det for det første at menn vesentlig oftere enn kvinner gir uttrykk for sine politiske meninger. Det er små aldersforskjeller, men det er den eldste aldersgruppen som i minst grad ytrer seg politisk i slike fora. Forskjellen mellom utdanningsgruppene er heller ikke stor, men interessant nok er det gruppene med lavest og høyest utdanning som oftest uttrykker politiske meninger. Tilsvarende er det en høyere andel av de med høyt utdannete foreldre, og de som bor i mindre sentrale kommuner.

Ved igjen å undersøke forskjellene ved hjelp av logistisk regresjon (se appendikstabell 4) finner vi at også kontrollert for de andre faktorene er det en positiv sammenheng mellom kjønn (menn) og det å uttrykke politiske meninger i lukkede grupper. Menn gjør altså dette oftere enn kvinner. Tilsvarende er det en negativ sammenheng med å ha videregående allmennfag/yrkesfag eller kort høyere utdanning, sammenlignet med det å ha grunnskole. Forskjellen mellom grunnskole og lang høyere utdanning er derimot ikke signifikant, og det er heller ingen signifikante 


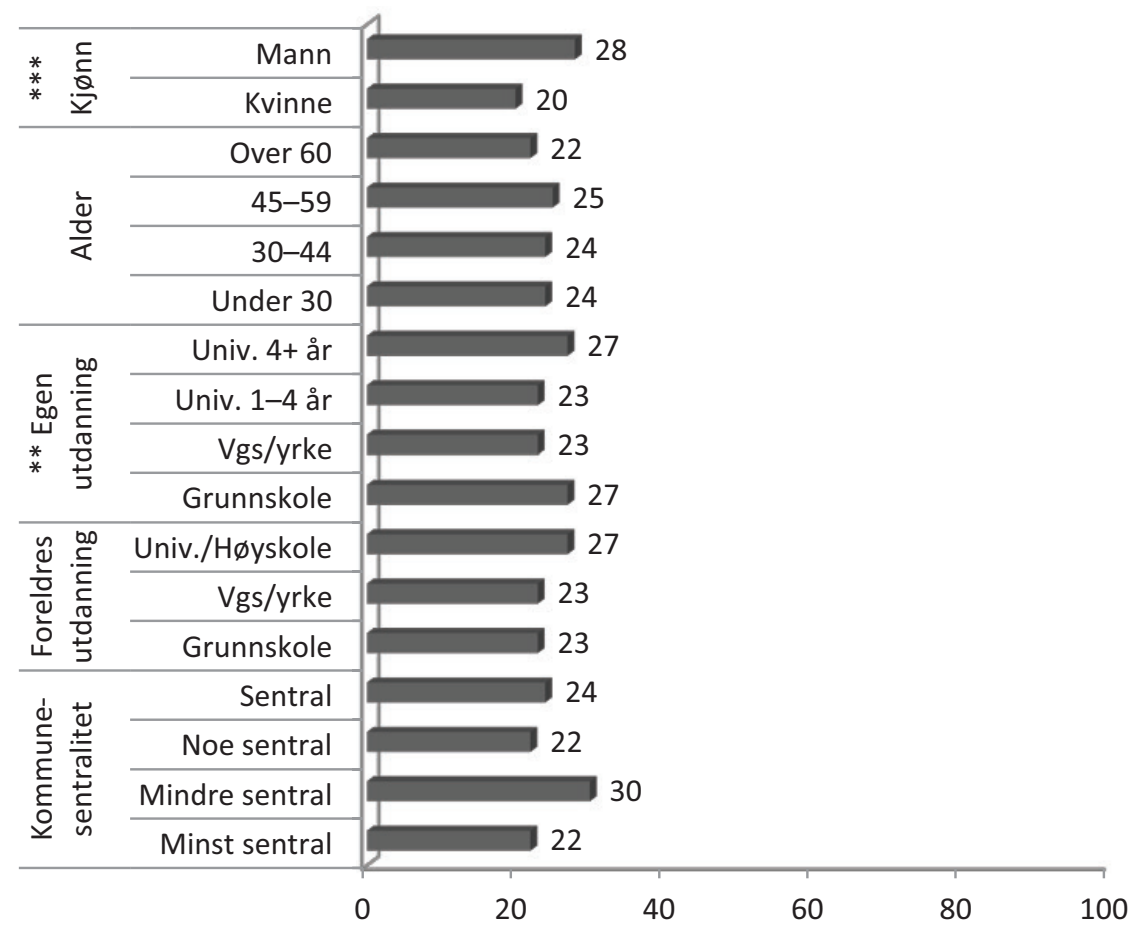

Figur 3: Gir uttrykk for politiske meninger i lukkede grupper på internett, fordelt på alder, kjønn, egen utdanning, foreldres utdanning og kommunesentralitet. Prosent (Chi.sig). ${ }^{\star \star \star} p<0.001$, ${ }^{\star \star}$ $\mathrm{p}<0.01,{ }^{\star} \mathrm{p}<0.05$

forskjeller mellom bostedskategoriene. Merk at det her ikke skilles mellom hvor disse lukkede gruppene befinner seg. Det kan altså være at selv om det ikke er signifikante forskjeller mellom gruppene med lavest og høyest utdanningsnivå, kan det være at disse politiske meningene uttrykkes på helt ulike steder, og omhandler helt forskjellige ting.

Hvor er det så de politiske meningene uttrykkes? Igjen kan vi se at Facebook er den rådende plattformen. Her spurte vi om hvor ulike politiske saker ble diskutert. 75 prosent av de som har diskutert på nett, har gjort det på Facebook. Den nest største arenaen er «diskusjonsforum», der 52 prosent oppgir at de har diskutert politiske saker. Deretter kommer «lokale nettaviser» med 33 prosent og riksmedier med 29 prosent. Videre har 24 prosent diskutert på «partinettsider», 22 prosent på «internasjonale medier» og 17 prosent på Twitter. At bare 14 prosent av de som har diskutert på nett, har gjort det på «andre sosiale medier», bekrefter også Facebooks dominerende posisjon. 


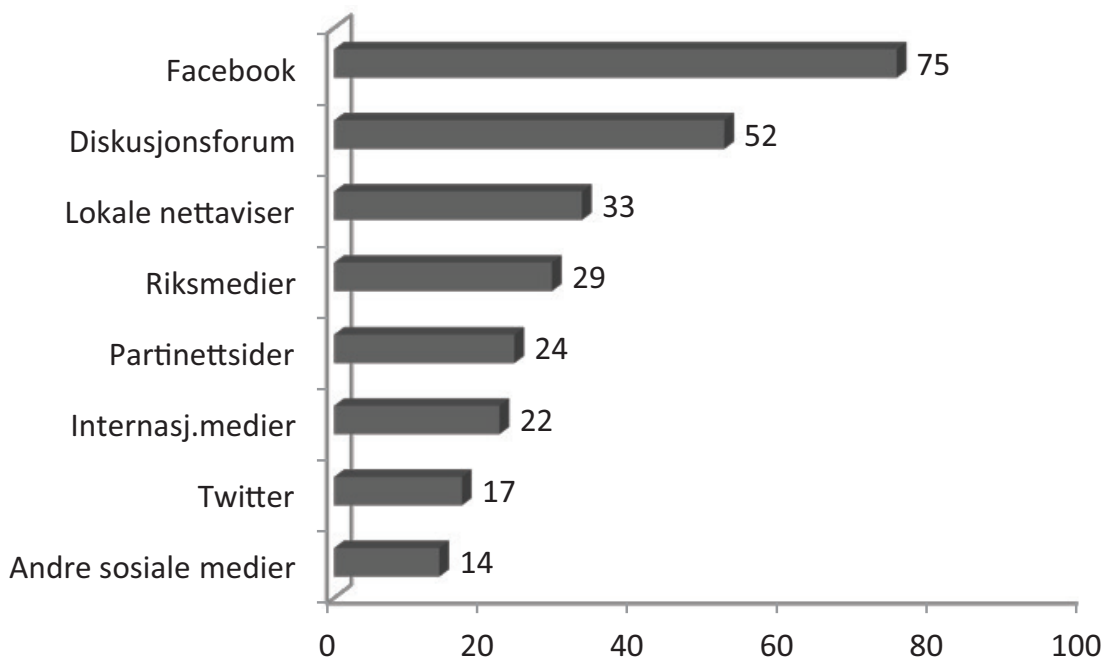

Figur 4: Andel som har diskutert politiske saker på nett på de ulike plattformene. Prosent $(\mathrm{N}=632)$.

Når vi så foretar separate regresjonsanalyser for hvert av de ulike stedene og analyserer hele utvalget, fremkommer det at det ikke er spesielt store forskjeller i hvilke grupper som diskuterer hvor (se appendikstabell 5). Det er imidlertid en signifikant negativ sammenheng mellom alder og det å diskutere på «andre sosiale medier» og på Twitter, mens det for de andre plattformene ikke er noen signifikant sammenheng med alder. For samtlige plattformer er det en signifikant positiv sammenheng med kjønn (menn), men styrken varierer noe og er minst på Facebook og størst på «andre sosiale medier» og på «internasjonale medier». Når det gjelder sammenhenger med utdanningsnivå, er det de med grunnskole (referansekategori) som utmerker seg, siden alle de andre kategoriene har negative sammenhenger. Det er altså de med grunnskoleutdanning som oftest diskuterer på nett. For «lokale nettaviser» er det imidlertid ingen av kategoriene for egen utdanning som er signifikant forskjellige fra grunnskolekategorien. Med unntak av at det er en signifikant sammenheng mellom å ha foreldre med videregående/yrkesfag og å diskutere politiske saker i «diskusjonsforum», ser det ikke ut til at foreldres utdanningsnivå har noen påvirkning på noen av arenaene. Heller ikke for kommunesentralitet er det noen signifikant sammenheng. 


\section{Digitalt frivillig arbeid}

Den siste faktoren vi undersøker, handler om det samfunnsengasjementet som kan komme til uttrykk gjennom å utføre digitalt frivillig arbeid. I en undersøkelse fra 2009 svarte 2,1 prosent at de hadde gjort en form for virtuelt frivillig arbeid for eksempelvis et nettsamfunn eller en diskusjonsgruppe, for eksempel veiledning av nye medlemmer, moderering av diskusjoner eller vedlikehold og utvikling av nettsider (Wollebæk \& Sivesind, 2010). Virtuelt frivillig arbeid ble her holdt separat fra ordinært frivillig arbeid for frivillige organisasjoner. Unge mennesker og menn hadde her en større sannsynlighet for å være digitalt frivillige. I 2014 hadde andelen virtuelt frivillige steget til 4,5 prosent (Eimhjellen, SteenJohnsen, Folkestad, \& Ødegård, 2018).

I undersøkelsen vår fra 2016 spurte vi om respondentene hadde utført frivillig arbeid for ulike typer frivillige organisasjoner, arrangementer eller nettverk det siste året, og videre om noe av dette frivillige arbeidet hadde blitt gjort i digitale kanaler. 20 prosent av de som hadde gjort frivillig arbeid, svarte bekreftende på at noe av det frivillige arbeidet ble utført i digitale kanaler (totalt 676 personer). Vi finner ingen kjønnsforskjeller når det gjelder digitalt frivillig arbeid, men vi finner at det er signifikant flere i de yngste alderskategoriene (24/25 prosent) enn i de eldste (19/15 prosent) som er digitalt frivillige. Det er også flere blant de med høy utdanningsbakgrunn enn de med lav (både egen og foreldres) som er digitalt frivillige.

Når vi gjennomfører en regresjonsanalyse, forsvinner sammenhengen med foreldres utdanning, samtidig som sammenhengen med kommunesentralitet blir signifikant. Regresjonsanalysen viser altså at jo yngre man er, jo høyere utdanning man har, og jo mindre sentral kommunen man bor i er, desto større sannsynlighet er det for å ha utført digitalt frivillig arbeid.

De mest vanlige aktivitetene var her informasjons- og kommunikasjonsarbeid (91 prosent), å lage og invitere til arrangement på nett (84 prosent), å utforme digitalt innhold (78 prosent) og å administrere Facebookgrupper (64 prosent). Ved nærmere analyser av sammenhengene mellom bakgrunnskjennetegn og de ulike typene arbeidsoppgaver (se appendikstabell 7) finner vi at yngre har større sannsynlighet enn eldre for å administrere Facebook-grupper, drive med teknisk nettsideutvikling, administrere 


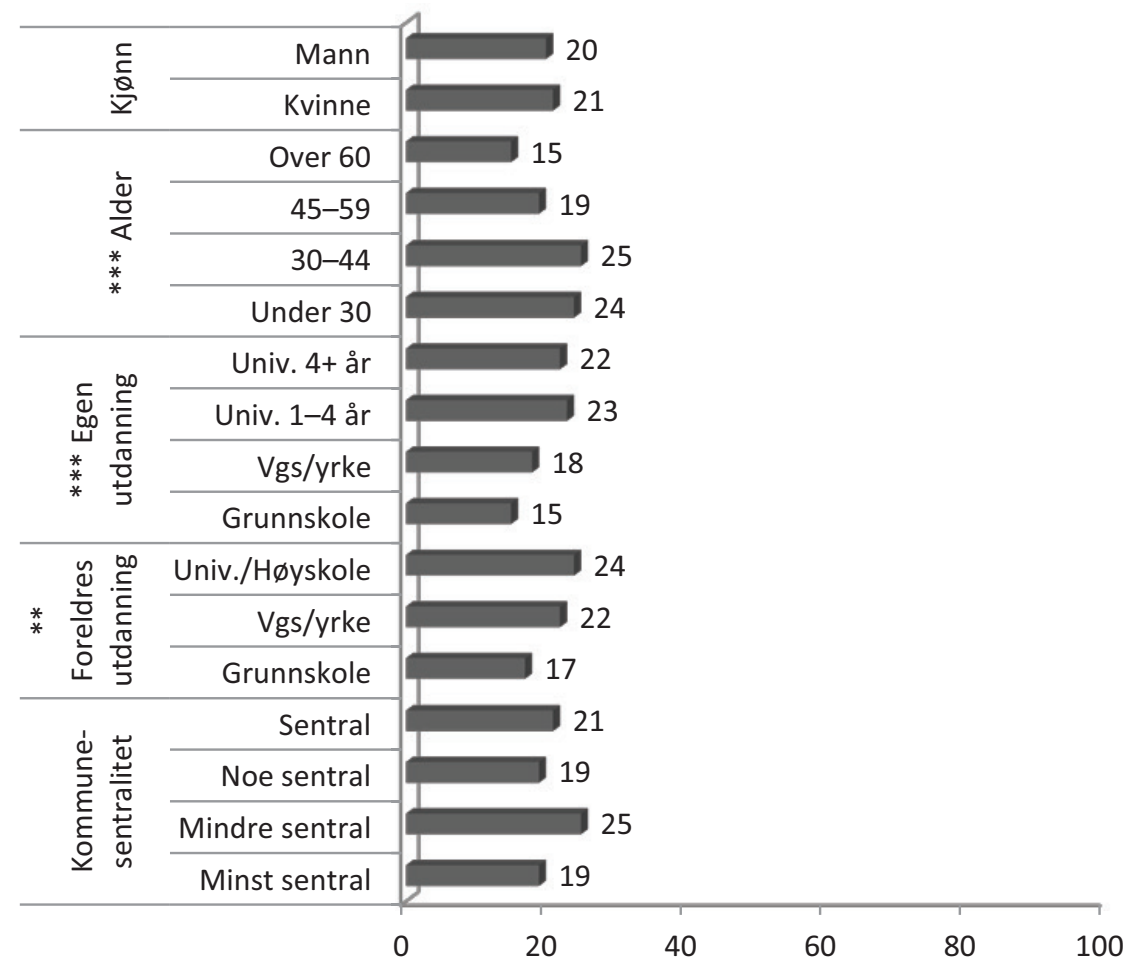

Figur 5: Andel som har deltatt i digitalt frivillig arbeid fordelt på bakgrunnskjennetegn. Prosent. (Maks $N=3307.){ }^{\star \star \star} p<0.001,{ }^{\star \star}{ }^{*} p<0.01,{ }^{\star} p<0.05$

nettdiskusjoner og kategorien annet. De med høyere utdanning (1-4 år) hadde også noe større sannsynlighet for å drive med teknisk nettsideutvikling, administrere nettdiskusjoner og kategorien annet, enn de som bare hadde grunnskole. De med foreldre med høyere utdanning hadde større sannsynlighet for å skaffe midler gjennom innsamling på nett, mens de i mindre sentrale kommuner hadde mindre sannsynlighet for å drive med teknisk nettsideutvikling enn personer i de minst sentrale kommunene.

\section{Diskusjon og konklusjon}

Med utgangspunkt i debatter omkring de potensielle demokratiserende effekter sosiale medier kan ha på samfunnsengasjement og kollektiv handling så har de sentrale spørsmålene i dette kapitlet dreid seg om i 


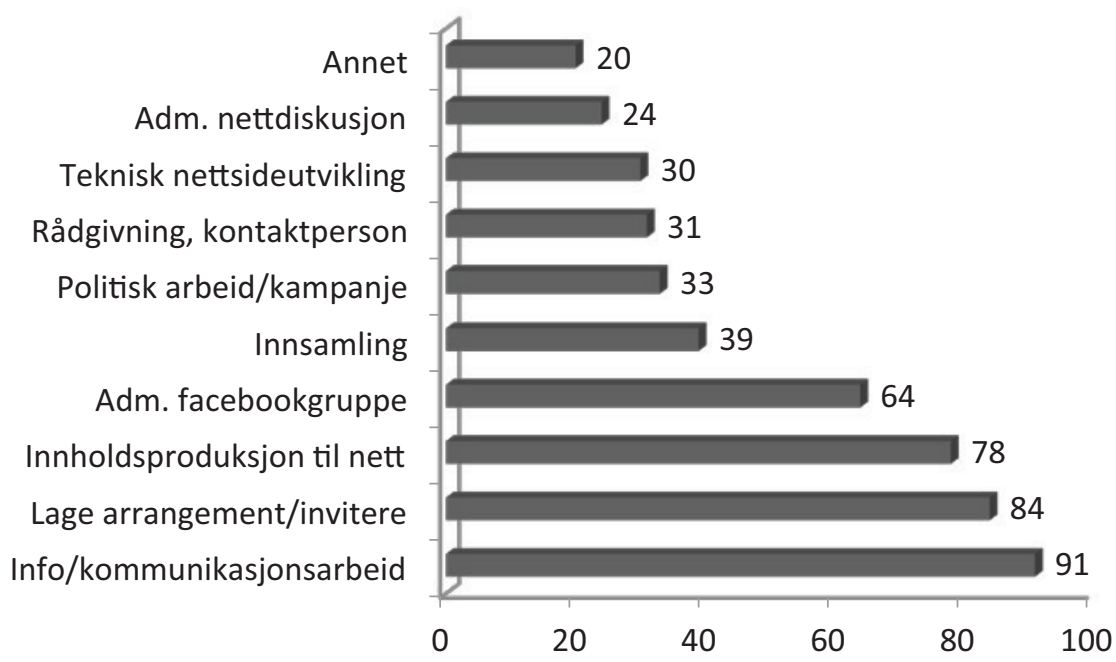

Figur 6: Fordeling på ulike typer digitalt frivillig arbeid. Prosent (Maks $N=651$ )

hvilken grad, og i så fall hvordan, sosiale forskjeller i samfunnsengasjement kommer til uttrykk på nettopp internett og i sosiale medier. Her har vi undersøkt forskjeller med hensyn til alder, kjønn, eget og foreldres utdanningsnivå, og kommunesentralitet for de digitale aktivitetene politisk interessestimulans, medlemskap i politiske Facebook-grupper, digitale meningsytringer og digitalt frivillig arbeid.

Basert på undersøkelsen fant vi at om lag en tredjedel av respondentene ble interessert i og ville finne ut mer om et spørsmål om politikk eller samfunn på grunn av noe de leste i sosiale medier. Dette er vanligere hos de unge og de som har foreldre med høy utdanning, og som bor i mer sentrale kommuner. For politiske gruppemedlemskap på Facebook finner vi at menn er oftere med i grupper for institusjonell politikk, og at yngre mennesker oftere er med i protestpolitiske grupper. De som bor mer sentralt, har en mindre sjanse for å være medlem i Facebook-grupper knyttet til institusjonell politikk. Når det gjelder politisk meningsytring på internett, er det opp mot 40 prosent som aldri gjør dette, verken i lukkede eller åpne fora. Vi finner her at det er vanligere for menn enn kvinner å uttrykke politiske meninger i lukkede grupper. Tilsvarende er det mindre vanlig med slik meningsytring blant de med videregående/yrkesfag og kort høyere utdanning, sammenlignet med de som har grunnskole som høyeste utdanning. Det er også blant 
de unge at digitalt frivillig arbeid er mest vanlig, samt blant de med høyere utdanning og de som bor i mindre sentrale kommuner.

Resultatene fra analysene viser oss altså et komplekst digitalt landskap der ulike bakgrunnsfaktorer spiller ulike roller for forskjellige typer digitale aktiviteter. I tråd med forventningene finner vi at de yngre er mer aktive enn de eldre i mange av deltakelsesformene, noe som kan tolkes som en aldersutjevning i deltakelse sammenlignet med mange tradisjonelle politiske deltakelsesformer, der yngre ofte er mer passive. I likhet med tidligere studier finner vi også en viss reproduksjon av klassiske kjønnsforskjeller, der menn er mer aktive enn kvinner, for eksempel når det gjelder medlemskap i Facebook-grupper for institusjonell politikk og politiske meningsytringer i lukkede grupper. Når det gjelder betydningen av hvor sentralt man bor, så finner vi at dette har en viss sammenheng med digitalt samfunnsengasjement, der de som bor mer sentralt, også er mer tilbøyelige til å få stimulert sin politiske interesse gjennom informasjon i sosiale medier, og de som bor mindre sentralt, er mer tilbøyelige til å være medlem i Facebook-grupper for politikere og politiske partier og for å drive med digitalt frivillig arbeid. Betydningen av fysisk sted betyr altså fortsatt noe for samfunnsengasjement selv om det foregår i digitale rom. Også for utdanningsbakgrunn, som er den mest sentrale bakgrunnsvariabelen for å forklare politisk deltakelse, finner vi en reproduksjon av ulikhetsmønstre, der de med høyere utdanning er mer aktive i de fleste formene for digitalt samfunnsengasjement.

Samtidig som internett og sosiale medier har utvidet repertoaret av samfunnsengasjerte handlinger, reproduseres også sosiale forskjeller i det digitale. Basert på de engasjementsformene vi har undersøkt i dette kapitlet, ser det ut til at demokratisering gjennom sosial utjevning av aktivitet i det digitale rom er begrenset. Digitaliseringens innvirkning på norsk samfunnsengasjement og kollektiv handling ser ikke ut til å velte om på klassiske mønstre for deltakelse. Ressurser, individkjennetegn og sosial posisjon strukturerer fortsatt samfunnsengasjement selv om det foregår i nye kanaler og med nye verktøy. Digitaliseringen har ikke frigjort mennesker fra etablerte sosiale strukturer, men har skapt nye muligheter for de som er engasjerte, og har til en viss grad skapt engasjementsformer som mobiliserer grupper som er mindre engasjerte i tradisjonelle offline-former for samfunnsengasjement. 


\section{Appendiks}

Appendikstabell 1: Deskriptive fordelinger på hovedvariabler.

\begin{tabular}{|c|c|c|c|}
\hline & & $\mathbf{N}$ & Prosent \\
\hline \multirow[t]{3}{*}{ Kjønn } & Menn & 1824 & 47,5 \\
\hline & Kvinner & 2019 & 52,5 \\
\hline & Sum & 3843 & 100 \\
\hline \multirow[t]{5}{*}{ Alder } & Under 30 år & 784 & 20,4 \\
\hline & 30-44 år & 975 & 25,4 \\
\hline & 45-59 år & 1239 & 32,2 \\
\hline & 60 år + & 845 & 40,7 \\
\hline & Sum & 3843 & 100 \\
\hline \multirow[t]{5}{*}{ Utdanning } & Grunnskole & 239 & 6,2 \\
\hline & Videregående/yrkesfag & 1413 & 36,8 \\
\hline & Universitet/høgskole 1-4 år & 1323 & 34,4 \\
\hline & Universitet/høgskole 4 år + & 868 & 22,6 \\
\hline & Sum & 3843 & 100 \\
\hline \multirow[t]{5}{*}{ Foreldres utdanning } & Grunnskole & 963 & 25,1 \\
\hline & Videregående/yrkesfag & 1824 & 47,5 \\
\hline & Universitet/høgskole & 791 & 20,6 \\
\hline & Ukjent & 265 & 6,9 \\
\hline & Sum & 3843 & 100 \\
\hline \multirow[t]{6}{*}{ Kommunesentralitet } & Minst sentrale kommuner & 352 & 9,2 \\
\hline & Mindre sentrale kommuner & 216 & 5,6 \\
\hline & Noe sentrale kommuner & 808 & 21 \\
\hline & Sentrale kommuner & 2408 & 62,7 \\
\hline & Ukjent & 59 & 1,5 \\
\hline & Sum & 3843 & 100 \\
\hline
\end{tabular}

Kilde: Sosiale medier-undersøkelsen 2016

Appendikstabell 2. Ville finne mer ut av en sak pga. noe man leste i sosiale medier. Logistisk regresjon.

\begin{tabular}{|l|l|}
\hline Variabler & Koeff. \\
\hline Kjønn & -1.65 \\
\hline Alder & $-6.40^{\star \star \star}$ \\
\hline Egen utd. Vgs/yrkesfag & -0.43 \\
\hline Egen utd. Univ. 1-4 år & 0.69 \\
\hline Egen utd. Univ. 4+ år & 0.94 \\
\hline Foreldre utd. Vgs/yrke & $2.57^{\star}$ \\
\hline Foreldre utd. Univ./Høgskole & $3.45^{\star \star \star}$ \\
\hline Kommunesentralitet & $2.74^{\star \star}$ \\
\hline Konstant & -1.73 \\
\hline Observasjoner & 3,060 \\
\hline
\end{tabular}

${ }^{\star \star \star} p<0.001,{ }^{\star \star} p<0.01,{ }^{\star} p<0.05$ 
Appendikstabell 3. Typer Facebook-grupper. Logistisk regresjon.

\begin{tabular}{|l|l|l|l|}
\hline Variabler & $\begin{array}{l}\text { Sosialt og } \\
\text { livsstil }\end{array}$ & $\begin{array}{l}\text { Institusjonell } \\
\text { politikk }\end{array}$ & Protestpolitikk \\
\hline Kjønn & $-2.48^{\star}$ & $2.14^{\star}$ & 1.43 \\
\hline Alder & $-4.83^{\star \star \star}$ & -0.81 & $-2.08^{\star}$ \\
\hline Egen utd. Vgs/yrkesfag & -1.19 & -0.20 & -0.14 \\
\hline Egen utd. Univ. 1-4 år & -1.24 & -0.25 & 0.32 \\
\hline Egen utd. Univ. 4+ år & -0.86 & -0.70 & 0.43 \\
\hline Foreldre utd. Vgs/yrkesfag & 1.52 & 0.61 & 1.47 \\
\hline Foreldre utd. Univ./Høgskole & 1.06 & 1.42 & $2.51^{\star}$ \\
\hline Kommunesentralitet & -1.88 & $-2.52^{\star}$ & -0.14 \\
\hline Konstant & $7.66^{\star \star \star}$ & -1.04 & $-3.64^{\star \star \star}$ \\
\hline Observasjoner & 2,458 & 2,774 & 2,676 \\
\hline
\end{tabular}

${ }^{\star \star \star} \mathrm{p}<0.001,{ }^{\star \star} \mathrm{p}<0.01,{ }^{\star} \mathrm{p}<0.05$

Kilde: Sosiale medier-undersøkelsen 2016

Appendikstabell 4. Uttrykke politiske meninger på lukkede grupper. Logistisk regresjon.

\begin{tabular}{|c|c|c|c|}
\hline & Modell 1 & Modell 2 & Modell 3 \\
\hline \multirow[t]{2}{*}{ Alder } & $-0,00102$ & 0,00141 & 0,00153 \\
\hline & $(0,003)$ & $(0,004)$ & $(0,004)$ \\
\hline \multirow[t]{2}{*}{ Kjønn (menn) } & $0,386^{\star \star \star}$ & $0,391^{\star \star \star}$ & $0,386^{\star \star \star}$ \\
\hline & $(0,097)$ & $(0,097)$ & $(0,097)$ \\
\hline Grunnskole & Ref. & & \\
\hline \multirow[t]{2}{*}{ VGS/yrkesfag } & $-0,429^{\star}$ & $-0,442^{\star}$ & $-0,439^{\star}$ \\
\hline & $(0,204)$ & $(0,205)$ & $(0,205)$ \\
\hline \multirow[t]{2}{*}{ Høyere utdanning 1-4 år } & $-0,434^{\star}$ & $-0,466^{\star}$ & $-0,461^{\star}$ \\
\hline & $(0,204)$ & $(0,206)$ & $(0,207)$ \\
\hline \multirow[t]{2}{*}{ Høyere utdanning $>4$ år } & $-0,192$ & $-0,245$ & $-0,240$ \\
\hline & $(0,210)$ & $(0,213)$ & $(0,213)$ \\
\hline Foreldre: Grunnskole & & Ref. & \\
\hline \multirow[t]{2}{*}{ Foreldre: VGS/yrkesfag } & & 0,0390 & 0,0390 \\
\hline & & $(0,125)$ & $(0,125)$ \\
\hline \multirow[t]{2}{*}{ Foreldre: Høyere utdanning } & & 0,272 & 0,270 \\
\hline & & $(0,152)$ & $(0,153)$ \\
\hline Minst sentrale kommuner & & & Ref. \\
\hline \multirow[t]{2}{*}{ Mindre sentrale kommuner } & & & 0,311 \\
\hline & & & $(0,250)$ \\
\hline \multirow[t]{2}{*}{ Noe sentrale kommuner } & & & $-0,0696$ \\
\hline & & & $(0,194)$ \\
\hline \multirow[t]{2}{*}{ Sentrale kommuner } & & & 0,0368 \\
\hline & & & $(0,174)$ \\
\hline \multirow[t]{2}{*}{ Konstant } & $-0,950^{\star \star \star}$ & $-1,117^{\star \star \star}$ & $-1,151^{\star \star \star}$ \\
\hline & $(0,216)$ & $(0,257)$ & $(0,297)$ \\
\hline aic & $2689,6^{\star \star \star}$ & $2689,2^{\star \star \star}$ & $2692,2^{\star \star \star}$ \\
\hline bic & 2724,4 & 2735,7 & 2756,0 \\
\hline II & $-1338,8$ & $-1336,6$ & $-1335,1$ \\
\hline $\mathrm{N}$ & 2444 & 2444 & 2444 \\
\hline
\end{tabular}

Standardfeil i parentes, ${ }^{\star} p<0.05,{ }^{\star \star} p<0.01,{ }^{\star \star \star} p<0.001$ 


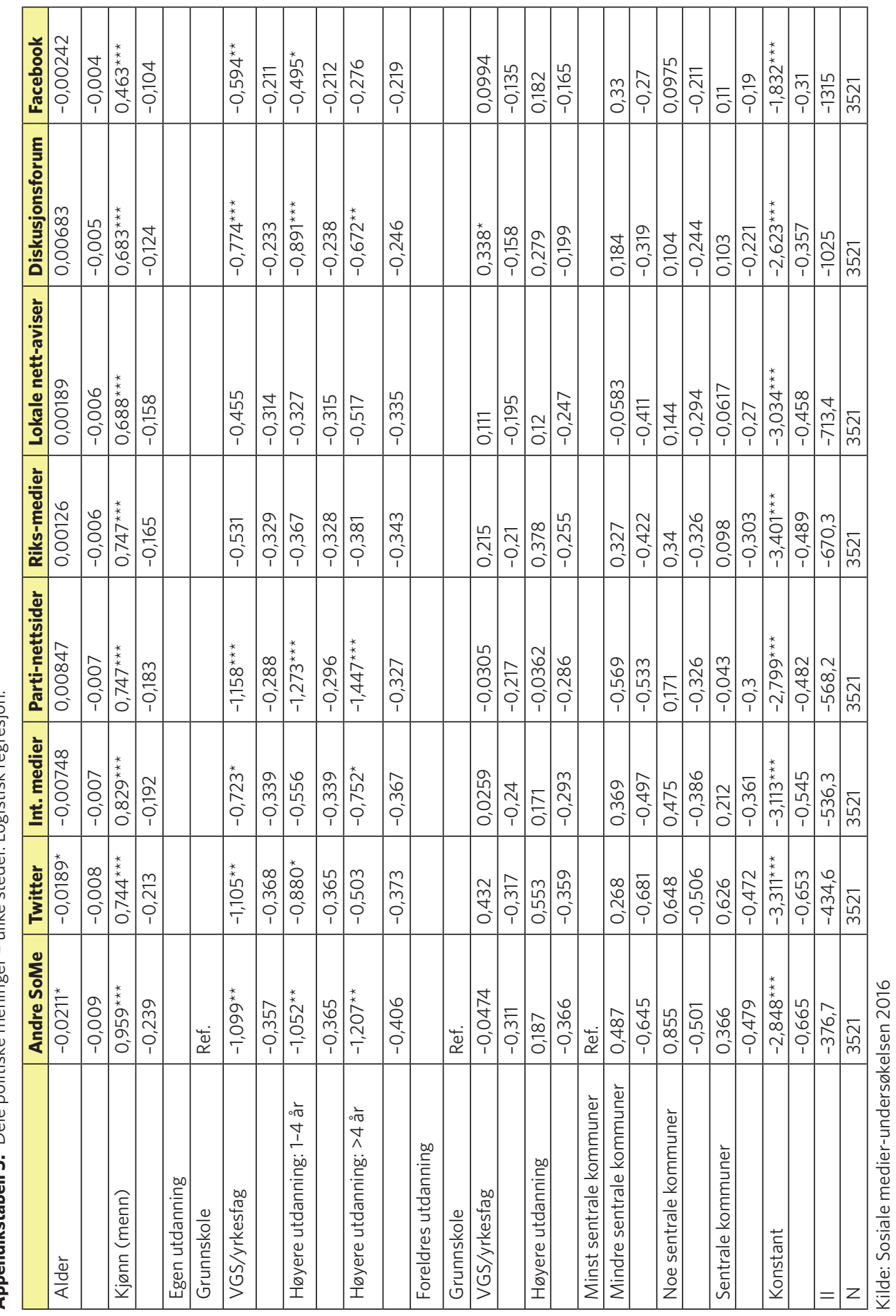


Appendikstabell 6: Digitalt frivillig arbeid. Logistisk regresjon.

\begin{tabular}{|c|c|c|c|}
\hline \multicolumn{4}{|c|}{ Utført digitalt frivillig arbeid siste år } \\
\hline & Modell 1 & Modell 2 & Modell 3 \\
\hline \multirow[t]{2}{*}{ Alder } & $-0,0180^{\star \star \star}$ & $-0,0169^{\star \star \star}$ & $-0,0173^{\star \star \star}$ \\
\hline & $-0,003$ & $-0,003$ & $-0,004$ \\
\hline \multirow[t]{2}{*}{ Kjønn (menn) } & 0,0524 & 0,0537 & 0,0494 \\
\hline & $-0,091$ & $-0,091$ & $-0,091$ \\
\hline \multicolumn{4}{|l|}{ Egen utdanning } \\
\hline Grunnskole & Ref. & & \\
\hline \multirow[t]{2}{*}{ VGS/yrkesfag } & 0,256 & 0,249 & 0,263 \\
\hline & $-0,23$ & $-0,23$ & $-0,231$ \\
\hline \multirow[t]{2}{*}{ Høyere utdanning: 1-4 år } & $0,654^{\star \star}$ & $0,638^{\star \star}$ & $0,656^{\star \star}$ \\
\hline & $-0,228$ & $-0,229$ & $-0,23$ \\
\hline \multirow[t]{2}{*}{ Høyere utdanning: >4 år } & $0,552^{\star}$ & $0,528^{\star}$ & $0,553^{\star}$ \\
\hline & $-0,235$ & $-0,237$ & $-0,238$ \\
\hline \multicolumn{4}{|l|}{ Foreldres utdanning } \\
\hline Grunnskole & & Ref. & \\
\hline \multirow[t]{2}{*}{ VGS/yrkesfag } & & 0,0717 & 0,0762 \\
\hline & & $-0,12$ & $-0,12$ \\
\hline \multirow[t]{2}{*}{ Høyere utdanning } & & 0,0984 & 0,115 \\
\hline & & $-0,145$ & $-0,146$ \\
\hline Minst sentrale kommuner & & & Ref. \\
\hline \multirow[t]{2}{*}{ Mindre sentrale kommuner } & & & $0,535^{\star}$ \\
\hline & & & $-0,233$ \\
\hline \multirow[t]{2}{*}{ Noe sentrale kommuner } & & & 0,115 \\
\hline & & & $-0,185$ \\
\hline \multirow[t]{2}{*}{ Sentrale kommuner } & & & 0,053 \\
\hline & & & $-0,167$ \\
\hline \multirow[t]{2}{*}{ Konstant } & $-1,020^{\star \star \star}$ & $-1,114^{\star \star \star}$ & $-1,210^{\star \star \star}$ \\
\hline & $-0,235$ & $-0,271$ & $-0,304$ \\
\hline aic & $3097,9^{\star \star \star}$ & $3101,4^{\star \star \star}$ & $3100,4^{\star \star \star}$ \\
\hline bic & 3134 & 3149,6 & 3166,7 \\
\hline II & $-1542,9$ & $-1542,7$ & $-1539,2$ \\
\hline $\mathrm{N}$ & 3056 & 3056 & 3056 \\
\hline
\end{tabular}

Kilde: Sosiale medier-undersøkelsen 2016 


\begin{tabular}{|c|c|c|c|c|c|c|c|c|c|c|c|c|c|}
\hline & 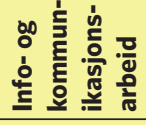 & 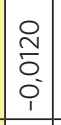 & $\begin{array}{l}\widehat{X} \\
0 \\
0 \\
0 \\
\end{array}$ & 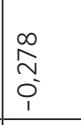 & 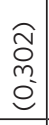 & & & $\begin{array}{l}\text { m } \\
0 \\
0 \\
0 \\
0 \\
1\end{array}$ & 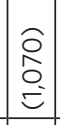 & $\begin{array}{l}\overline{0} \\
0 \\
0 \\
1 \\
\end{array}$ & 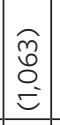 & $\begin{array}{l}0 \\
0 \\
0 \\
0 \\
0 \\
1\end{array}$ & $\begin{array}{l}\text { бa } \\
\text { o } \\
\Xi \\
\end{array}$ \\
\hline & 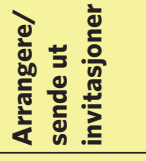 & $\mid$\begin{tabular}{c}
0 \\
\multirow{2}{*}{} \\
0 \\
0 \\
0 \\
1
\end{tabular} & $\begin{array}{l}\hat{\sigma} \\
\dot{0} \\
0 \\
0 \\
0\end{array} \mid$ & $\begin{array}{l}m \\
0 \\
\tilde{N} \\
0 \\
0\end{array}$ & 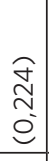 & & & $\begin{array}{l}\text { ก } \\
\text { กิ } \\
0 \\
\end{array}$ & 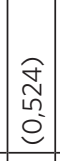 & $\stackrel{\stackrel{\sim}{N}}{\underset{0}{0}}$ & 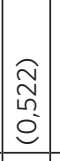 & 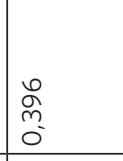 & $\begin{array}{l}\widetilde{J} \\
\tilde{J} \\
0 \\
0 \\
0\end{array}$ \\
\hline & 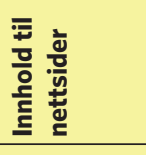 & \begin{tabular}{|l|}
$\infty$ \\
$m$ \\
$m$ \\
0 \\
0 \\
0 \\
0 \\
1 \\
\end{tabular} & \begin{tabular}{|l|}
0 \\
0 \\
0 \\
0 \\
0 \\
\end{tabular} & 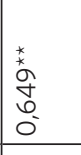 & \begin{tabular}{|c|}
0 \\
0 \\
0 \\
0 \\
0 \\
0 \\
\end{tabular} & & & $\begin{array}{l}\sigma \\
\sigma \\
0 \\
0 \\
0\end{array}$ & \begin{tabular}{|c|} 
\\
0 \\
0 \\
0 \\
0 \\
\end{tabular} & \begin{tabular}{|l} 
\\
ஸn \\
0 \\
0 \\
0
\end{tabular} & 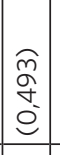 & \begin{tabular}{l}
\multirow{1}{*}{} \\
0 \\
$m$ \\
$O$ \\
0 \\
0 \\
0 \\
1 \\
\end{tabular} & 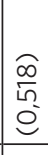 \\
\hline & 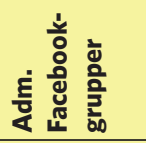 & 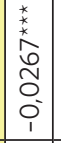 & $\begin{array}{l}\hat{\delta} \\
0 \\
0 \\
0 \\
\end{array}$ & $\begin{array}{l}0 \\
0 \\
1 \\
1\end{array}$ & $\begin{array}{l}6 \\
\frac{6}{0} \\
0\end{array}$ & & & $\frac{\hat{m}}{\sigma^{\circ}}$ & 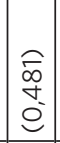 & $\begin{array}{l}7 \\
0 \\
0 \\
0\end{array}$ & 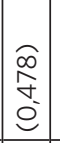 & \begin{tabular}{l}
\multirow{2}{m}{} \\
J \\
0 \\
0 \\
1
\end{tabular} & $\begin{array}{l}6 \\
0 \\
0 \\
0 \\
0\end{array}$ \\
\hline : & 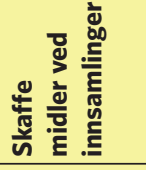 & 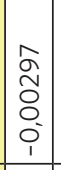 & $\begin{array}{l}\widehat{I} \\
0 \\
0 \\
0 \\
0\end{array}$ & 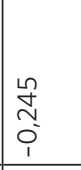 & 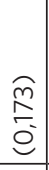 & & & $\begin{array}{l}0 \\
0 \\
0 \\
m \\
0 \\
1\end{array}$ & 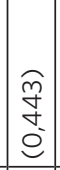 & $\begin{array}{l}\hat{N} \\
\hat{N} \\
0 \\
1\end{array}$ & \begin{tabular}{l}
$\hat{\tilde{y}}$ \\
\multirow{+}{*}{} \\
$\stackrel{-}{0}$
\end{tabular} & \begin{tabular}{l}
\multirow{2}{*}{} \\
$\tilde{m}$ \\
$\alpha$ \\
0 \\
0 \\
1
\end{tabular} & $\begin{array}{l}0 \\
0 \\
0 \\
0 \\
0 \\
0\end{array}$ \\
\hline 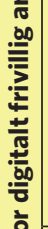 & 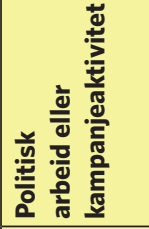 & \begin{tabular}{|c|}
0 \\
0 \\
0 \\
0 \\
0 \\
1
\end{tabular} & $\begin{array}{l}0 \\
0 \\
0 \\
0 \\
0 \\
0\end{array}$ & \begin{tabular}{|l} 
\\
$\hat{\alpha}$ \\
$o$ \\
0 \\
0 \\
\end{tabular} & $\frac{\widehat{\infty}}{\frac{\infty}{-}}$ & & & \begin{tabular}{|l}
$\infty$ \\
$\stackrel{\infty}{n}$ \\
0 \\
$i$ \\
1
\end{tabular} & 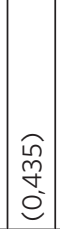 & 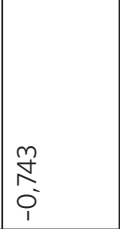 & 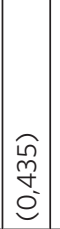 & $\begin{array}{l}0 \\
0 \\
0 \\
0 \\
0 \\
1\end{array}$ & $\begin{array}{l}\overline{6} \\
\dot{\sigma} \\
0 \\
0\end{array}$ \\
\hline 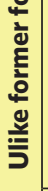 & 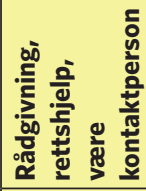 & \begin{tabular}{|l|} 
\\
0 \\
2 \\
0 \\
0 \\
0 \\
1 \\
\end{tabular} & $\begin{array}{l}0 \\
0 \\
0 \\
0 \\
0\end{array}$ & $\begin{array}{l}\stackrel{0}{ } \\
\tilde{n} \\
0 \\
0\end{array}$ & $\begin{array}{l}\frac{\omega}{\infty} \\
\infty \\
\overline{0}\end{array}$ & & & \begin{tabular}{l}
$\hat{m}$ \\
\multirow{+}{0}{} \\
i \\
\end{tabular} & 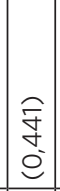 & $\begin{array}{l}0 \\
0 \\
0 \\
0 \\
1 \\
1\end{array}$ & 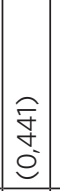 & $\begin{array}{l}0 \\
0 \\
\infty \\
0 \\
1 \\
\end{array}$ & 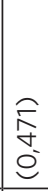 \\
\hline & 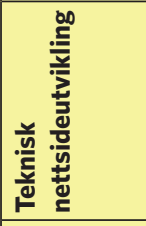 & 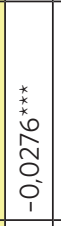 & \begin{tabular}{|l|}
0 \\
0 \\
0 \\
0 \\
0 \\
0
\end{tabular} & 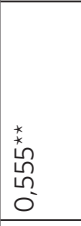 & $\begin{array}{l}\widehat{\sigma} \\
\sigma \\
\overline{0}\end{array}$ & & & \begin{tabular}{l}
0 \\
\multirow{1}{*}{} \\
0 \\
\\
1
\end{tabular} & 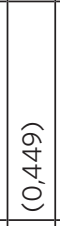 & $\begin{array}{l}* \\
\infty \\
\alpha \\
\alpha \\
0 \\
1 \\
\end{array}$ & 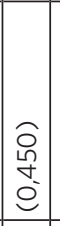 & 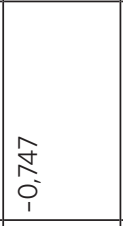 & 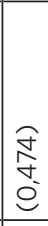 \\
\hline & 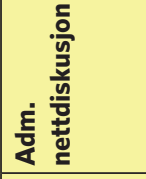 & \begin{tabular}{|l|}
$*$ \\
$\infty$ \\
0 \\
$\sigma$ \\
0 \\
0 \\
1
\end{tabular} & $\begin{array}{l}\hat{\sigma} \\
0 \\
0 \\
0 \\
0\end{array} \mid$ & $\stackrel{\substack{n \\
ָ}}{o}$ & 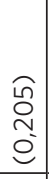 & & & $\begin{array}{l}\tilde{0} \\
\tilde{n} \\
0 \\
0 \\
0 \\
1\end{array}$ & $\begin{array}{l}\text { f } \\
\text { f. } \\
\text { O }\end{array}$ & 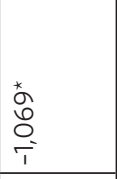 & 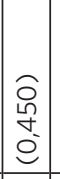 & $\begin{array}{l}* \\
0 \\
\alpha \\
0 \\
0 \\
1\end{array}$ & $\begin{array}{l}0 \\
0 \\
0 \\
+ \\
0 \\
0\end{array}$ \\
\hline & 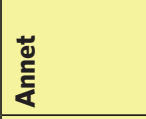 & \begin{tabular}{|l|}
\multirow{*}{*}{} \\
$\stackrel{2}{0}$ \\
$\tilde{n}$ \\
0 \\
0 \\
1 \\
\end{tabular} & $\begin{array}{l}\hat{\bar{E}} \\
0 \\
\overline{0}\end{array}$ & $\begin{array}{l}0 \\
\stackrel{\leftrightarrow}{f} \\
0\end{array}$ & 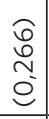 & & $\mid \stackrel{+}{\Phi}$ & $\begin{array}{l}\text { N } \\
\text { N } \\
\text { ñ } \\
0 \\
1\end{array}$ & 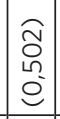 & $\begin{array}{l}\stackrel{0}{a} \\
\stackrel{m}{T} \\
\bar{T}\end{array}$ & 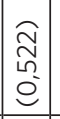 & 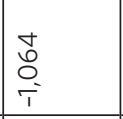 & $\begin{array}{l}\hat{\Sigma} \\
\tilde{0} \\
0 \\
0\end{array}$ \\
\hline & & $\frac{\frac{\bar{d}}{0}}{\frac{0}{\alpha}}$ & & 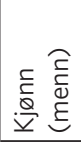 & & 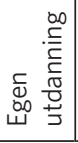 & \begin{tabular}{|c|}
$\frac{0}{0}$ \\
v \\
\\
$\frac{5}{5}$ \\
$\frac{1}{0}$
\end{tabular} & 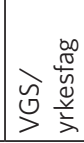 & & 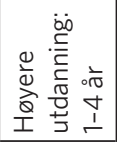 & & 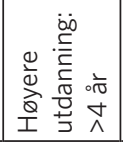 & \\
\hline
\end{tabular}




\begin{tabular}{|c|c|c|c|c|c|c|c|c|c|c|c|c|c|c|c|c|c|}
\hline & & 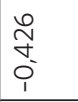 & $\begin{array}{l}\overparen{\Xi} \\
\check{J} \\
\stackrel{0}{-}\end{array}$ & $\begin{array}{l}\text { 年 } \\
\text { m } \\
0 \\
\\
\end{array}$ & $\begin{array}{l}\tilde{m} \\
0 \\
0 \\
0 \\
0 \\
0\end{array}$ & & $\begin{array}{l}\hat{\sigma} \\
\stackrel{0}{-} \\
\stackrel{-}{1}\end{array}$ & $\begin{array}{l}\hat{\partial} \\
\stackrel{r}{1} \\
\hat{o} \\
\end{array}$ & $\begin{array}{l}0 \\
\infty \\
0 \\
1 \\
\end{array}$ & $\begin{array}{l}0 \\
0 \\
0 \\
0 \\
0 \\
0\end{array}$ & 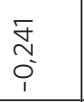 & 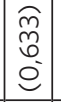 & 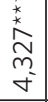 & 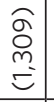 & $\underset{\frac{\pi}{N}}{\frac{\pi}{1}}$ & $\frac{m}{6}$ & \\
\hline & & $\begin{array}{l}\overline{1} \\
0 \\
0 \\
0 \\
1 \\
1\end{array}$ & 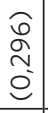 & $\begin{array}{l}\infty \\
\infty \\
\infty \\
0 \\
0 \\
0 \\
1\end{array}$ & $\begin{array}{l}\hat{\sigma} \\
\stackrel{0}{m} \\
m \\
\stackrel{0}{-}\end{array}$ & & $\begin{array}{l}m \\
\stackrel{0}{0} \\
i \\
\end{array}$ & 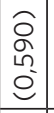 & $\begin{array}{l}\sigma \\
m \\
m \\
o \\
1\end{array}$ & $\begin{array}{l}\hat{\sigma} \\
\hat{N} \\
\\
0 \\
0\end{array}$ & \begin{tabular}{l}
\multirow{\sim}{U}{} \\
0 \\
$i$ \\
\end{tabular} & $\mid \begin{array}{l}6 \\
2 \\
o \\
+ \\
0\end{array}$ & $\begin{array}{l}\text { t. } \\
0 \\
\stackrel{n}{2} \\
\sim \\
v\end{array}$ & $\begin{array}{l}\overparen{1} \\
\infty \\
\tilde{0} \\
\end{array}$ & 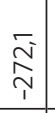 & $\frac{0}{6}$ & \\
\hline & & $\begin{array}{l}\text { N̂ } \\
0 \\
8 \\
0 \\
0 \\
\end{array}$ & 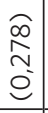 & $\begin{array}{l}0 \\
0 \\
0 \\
1\end{array}$ & 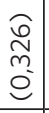 & & $\begin{array}{l}0 \\
0 \\
\infty \\
0 \\
1 \\
1\end{array}$ & 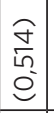 & $\begin{array}{l}1 \\
0 \\
0 \\
0 \\
0 \\
1 \\
\end{array}$ & $\begin{array}{l}0 \\
o \\
o \\
0 \\
0\end{array}$ & 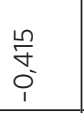 & \begin{tabular}{|c|}
0 \\
$\sigma$ \\
$\sigma$ \\
0 \\
\end{tabular} & $\stackrel{\sigma}{\check{\sigma}}$ & $\begin{array}{l}7 \\
\stackrel{1}{0} \\
\stackrel{0}{0}\end{array}$ & $\begin{array}{l}\stackrel{\nabla}{\vec{*}} \\
\stackrel{m}{1} \\
\end{array}$ & $\frac{0}{6}$ & \\
\hline & & $\begin{array}{l}\stackrel{v}{N} \\
\stackrel{0}{0} \\
0\end{array}$ & 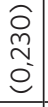 & \begin{tabular}{l}
0 \\
\multirow{2}{0}{} \\
0 \\
0 \\
0
\end{tabular} & 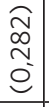 & & $\begin{array}{l}0 \\
0 \\
\stackrel{1}{n} \\
0 \\
1 \\
\end{array}$ & \begin{tabular}{l}
$\tilde{J}$ \\
\multirow{y}{*}{} \\
$\stackrel{-}{0}$
\end{tabular} & 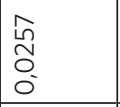 & 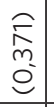 & $\begin{array}{l}\hat{0} \\
n \\
0 \\
i \\
1\end{array}$ & \begin{tabular}{|c|}
$\widetilde{夭}$ \\
$m$ \\
$m$ \\
$\varrho$ \\
$O$
\end{tabular} & $\begin{array}{l}\stackrel{*}{*} \\
\stackrel{*}{*} \\
\stackrel{\infty}{\infty} \\
\stackrel{-}{-} \\
\end{array}$ & $\begin{array}{l}\hat{\sigma} \\
\tilde{\omega} \\
\stackrel{-}{0} \\
0\end{array}$ & \begin{tabular}{c|}
$\sim$ \\
$\tilde{N}$ \\
$\infty$ \\
$m$ \\
1 \\
\end{tabular} & $\begin{array}{l}\infty \\
0 \\
0 \\
\end{array}$ & \\
\hline & & $\begin{array}{l}\mathscr{0} \\
\stackrel{N}{N} \\
0\end{array}$ & $\begin{array}{l}\underset{\hat{n}}{\tilde{N}} \\
\stackrel{0}{0}\end{array}$ & \begin{tabular}{l}
\multirow{*}{*}{} \\
$\infty$ \\
$\infty$ \\
$1 n$ \\
0 \\
0
\end{tabular} & 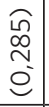 & & $\begin{array}{l}\text { N } \\
\stackrel{1}{ } \\
\text { O' } \\
1\end{array}$ & $\begin{array}{l}\underset{\tilde{J}}{m} \\
\stackrel{-}{-} \\
\stackrel{c}{0}\end{array}$ & \begin{tabular}{l}
0 \\
$\stackrel{0}{N}$ \\
\hdashline \\
0 \\
1
\end{tabular} & 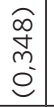 & \begin{tabular}{l}
\multirow{N}{N}{} \\
$m$ \\
0 \\
1
\end{tabular} & $\left|\begin{array}{l}\frac{\alpha}{\infty} \\
m \\
\varrho \\
\varrho\end{array}\right|$ & $\begin{array}{l}\bar{\sigma} \\
\dot{0} \\
0\end{array}$ & $\begin{array}{l}0 \\
0 \\
0 \\
0 \\
0 \\
0\end{array}$ & $\begin{array}{l}9 \\
0 \\
0 \\
0 \\
1 \\
1\end{array}$ & $\frac{0}{6}$ & \\
\hline & & $\begin{array}{l}\underset{m}{\mathbb{N}} \\
\stackrel{-}{0} \\
1\end{array}$ & 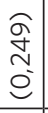 & $\begin{array}{l}\infty \\
\infty \\
\sim \\
0 \\
0\end{array}$ & 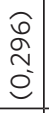 & & $\begin{array}{l}0 \\
\infty \\
⿱ 亠 乂 \\
0 \\
0 \\
0\end{array}$ & 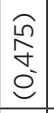 & \begin{tabular}{|c}
0 \\
$m$ \\
$m$ \\
0 \\
0
\end{tabular} & $\begin{array}{l}0 \\
\infty \\
m \\
m \\
0\end{array}$ & 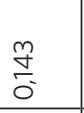 & \begin{tabular}{|c|}
$\tilde{f}$ \\
$\tilde{f}$ \\
0 \\
0 \\
\end{tabular} & $\begin{array}{l}m \\
0 \\
\infty \\
0 \\
0 \\
0\end{array}$ & 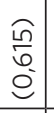 & $\begin{array}{c}\underset{f}{+} \\
\hat{m} \\
\end{array}$ & $\overline{6}$ & \\
\hline & & $\begin{array}{l}\frac{a}{2} \\
0 \\
\end{array}$ & $\begin{array}{l}\widehat{\hat{n}} \\
\stackrel{2}{0} \\
\stackrel{0}{-}\end{array}$ & \begin{tabular}{l}
0 \\
0 \\
\multirow{0}{0}{} \\
0
\end{tabular} & $\begin{array}{l}\hat{0} \\
\text { m } \\
\text { O্ర }\end{array}$ & & $\begin{array}{l}0 \\
0 \\
0 \\
0 \\
0 \\
\end{array}$ & 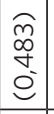 & $\begin{array}{l}\sqrt{n} \\
\stackrel{N}{N} \\
0\end{array}$ & $\begin{array}{l}\widehat{\sigma} \\
m \\
\bar{m} \\
\bar{c}\end{array}$ & $\frac{\infty}{=}$ & 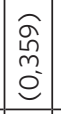 & $\begin{array}{l}\hat{N} \\
\underline{0} \\
0 \\
1 \\
\end{array}$ & $\begin{array}{l}0 \\
0 \\
\mathbb{b} \\
0 \\
0\end{array}$ & $\begin{array}{l}0 \\
m \\
0 \\
m \\
1\end{array}$ & $\begin{array}{l}0 \\
0 \\
\end{array}$ & \\
\hline & & 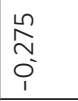 & $\begin{array}{l}\widehat{\sigma} \\
\stackrel{2}{0} \\
\stackrel{0}{0}\end{array}$ & $\frac{\text { Iv }}{\stackrel{0}{i}}$ & $\begin{array}{l}\widehat{\Xi} \\
\stackrel{m}{m} \\
\stackrel{0}{0}\end{array}$ & & $\frac{\stackrel{*}{m}}{\stackrel{T}{T}}$ & 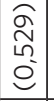 & $\begin{array}{c}0 \\
m \\
m \\
0 \\
1 \\
1\end{array}$ & 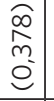 & \begin{tabular}{l}
$m$ \\
\multirow{\ddagger}{*}{} \\
$\stackrel{-}{1}$
\end{tabular} & 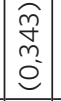 & $\begin{array}{l}\text { o } \\
\stackrel{n}{\sim} \\
\stackrel{2}{n}\end{array}$ & $\begin{array}{l}\widehat{c} \\
\hat{n} \\
\stackrel{-}{0} \\
0\end{array}$ & 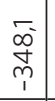 & $\begin{array}{l}\text { J } \\
\text { | }\end{array}$ & 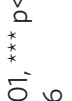 \\
\hline & & $\begin{array}{l}0 \\
\stackrel{m}{+} \\
0 \\
1\end{array}$ & $\begin{array}{l}\hat{\Sigma} \\
\hat{N} \\
\tilde{0} \\
\end{array}$ & \begin{tabular}{l}
0 \\
\multirow{2}{N}{} \\
0 \\
1 \\
1
\end{tabular} & $\begin{array}{l}\overparen{\approx} \\
m \\
\stackrel{0}{0}\end{array}$ & & 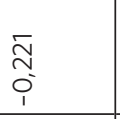 & $\begin{array}{l}0 \\
0 \\
0 \\
0 \\
0 \\
\end{array}$ & $\begin{array}{l}\text { Oo } \\
\stackrel{2}{2} \\
0\end{array}$ & $\begin{array}{l}0 \\
0 \\
d \\
0 \\
0\end{array}$ & 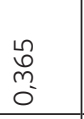 & 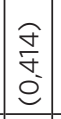 & $\begin{array}{l}\bar{\infty} \\
\stackrel{N}{\sim} \\
0\end{array}$ & $\begin{array}{l}\sigma \\
\hat{\sigma} \\
\dot{0} \\
0 \\
0\end{array}$ & $\begin{array}{l}\infty \\
\tilde{N} \\
m \\
1\end{array}$ & $\begin{array}{l}\text { ठ } \\
\end{array}$ & 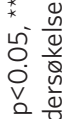 \\
\hline & 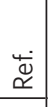 & $\begin{array}{l}\hat{\alpha} \\
\text { m } \\
0\end{array}$ & 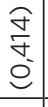 & 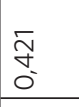 & \begin{tabular}{l}
$\hat{n}$ \\
\multirow{+}{*}{} \\
$\stackrel{0}{0}$
\end{tabular} & $\propto$ & $\stackrel{\text { In }}{\circ}$ & 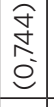 & $\begin{array}{l}0 \\
0 \\
0 \\
0 \\
0 \\
0\end{array}$ & $\begin{array}{l}\overline{\tilde{m}} \\
0 \\
0 \\
0\end{array}$ & $\begin{array}{l}\infty \\
0 \\
\text { ñ } \\
0\end{array}$ & 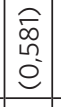 & $\begin{array}{l}\infty \\
0 \\
0 \\
0 \\
1 \\
\end{array}$ & $\begin{array}{l}0 \\
\infty \\
\infty \\
\infty \\
0 \\
0\end{array}$ & 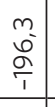 & \begin{tabular}{|c}
$m$ \\
$\dot{q}$ \\
\end{tabular} & 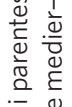 \\
\hline 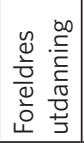 & 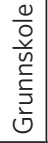 & 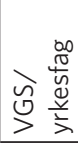 & & 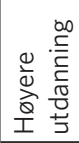 & & 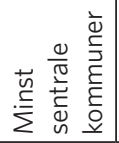 & 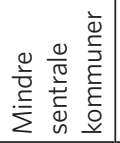 & & 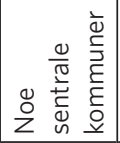 & & 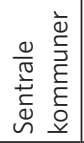 & & 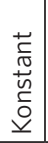 & & $=$ & $z$ & 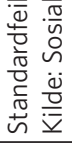 \\
\hline
\end{tabular}


KAPITTEL 3

Appendikstabell 8: Bidrag til crowdsourcing. Logistisk regresjon

\begin{tabular}{|c|c|c|c|c|c|}
\hline \multicolumn{6}{|c|}{ Bidratt til crowdsourcing } \\
\hline & Annet & Arbeidskraft & Kunnskap & Erfaring & Penger \\
\hline \multirow[t]{2}{*}{ Alder } & 0,0193 & $-0,0215^{\star \star}$ & 0,000730 & $-0,00794$ & $-0,0197^{\star \star \star}$ \\
\hline & $(0,017)$ & $(0,008)$ & $(0,007)$ & $(0,008)$ & $(0,005)$ \\
\hline \multirow[t]{2}{*}{ Kjønn (menn) } & $-0,443$ & $0,508^{\star}$ & 0,316 & $0,450^{\star}$ & 0,104 \\
\hline & $(0,482)$ & $(0,210)$ & $(0,182)$ & $(0,220)$ & $(0,129)$ \\
\hline \multicolumn{6}{|l|}{ Egen utdanning } \\
\hline Grunnskole & Ref. & & & & \\
\hline \multirow[t]{2}{*}{ VGS/yrkesfag } & $-0,578$ & $-0,161$ & $-0,155$ & $-0,133$ & $1,062^{\star}$ \\
\hline & $(1,140)$ & $(0,394)$ & $(0,403)$ & $(0,435)$ & $(0,437)$ \\
\hline \multirow{2}{*}{$\begin{array}{l}\text { Høyere utdanning: } \\
\text { 1-4 år }\end{array}$} & $-0,468$ & $-0,340$ & $-0,182$ & $-0,508$ & $1,353^{\star \star}$ \\
\hline & $(1,126)$ & $(0,408)$ & $(0,406)$ & $(0,454)$ & $(0,436)$ \\
\hline \multirow[t]{2}{*}{ Høyere utdanning: >4 år } & 0,423 & $-0,345$ & $-0,153$ & $-0,303$ & $1,528^{\star \star \star}$ \\
\hline & $(1,099)$ & $(0,434)$ & $(0,422)$ & $(0,467)$ & $(0,442)$ \\
\hline \multicolumn{6}{|l|}{ Foreldres utdanning } \\
\hline Grunnskole & Ref. & & & & \\
\hline \multirow[t]{2}{*}{ VGS/yrkesfag } & 0,156 & 0,110 & $0,564^{\star}$ & 0,106 & $0,376^{\star}$ \\
\hline & $(0,646)$ & $(0,296)$ & $(0,262)$ & $(0,308)$ & $(0,191)$ \\
\hline \multirow[t]{2}{*}{ Høyere utdanning } & 0,748 & 0,355 & $0,727^{\star}$ & 0,659 & $0,525^{\star}$ \\
\hline & $(0,703)$ & $(0,342)$ & $(0,305)$ & $(0,346)$ & $(0,217)$ \\
\hline $\begin{array}{l}\text { Minst sentrale } \\
\text { kommuner }\end{array}$ & Ref. & & & & \\
\hline \multirow{2}{*}{$\begin{array}{l}\text { Mindre sentrale } \\
\text { kommuner }\end{array}$} & 0 & 0,505 & $-0,212$ & $-0,0675$ & 0,0509 \\
\hline & (.) & $(0,511)$ & $(0,510)$ & $(0,635)$ & $(0,368)$ \\
\hline \multirow[t]{2}{*}{ Noe sentrale kommuner } & $-0,484$ & 0,00890 & $-0,419$ & $-0,00165$ & $-0,108$ \\
\hline & $(0,918)$ & $(0,432)$ & $(0,376)$ & $(0,460)$ & $(0,274)$ \\
\hline \multirow[t]{2}{*}{ Sentrale kommuner } & $-0,110$ & 0,0707 & 0,0177 & 0,148 & 0,0935 \\
\hline & $(0,769)$ & $(0,384)$ & $(0,316)$ & $(0,408)$ & $(0,241)$ \\
\hline \multirow[t]{2}{*}{ Konstant } & $-5,827^{\star \star \star}$ & $-2,870^{\star \star \star}$ & $-3,707^{\star \star \star}$ & $-3,586^{\star \star \star}$ & $-3,315^{\star \star \star}$ \\
\hline & $(1,461)$ & $(0,613)$ & $(0,561)$ & $(0,660)$ & $(0,521)$ \\
\hline$\|$ & $-112,9$ & $-440,2$ & $-549,1$ & $-407,1$ & $-929,0$ \\
\hline $\mathrm{N}$ & 3330 & 3521 & 3521 & 3521 & 3521 \\
\hline
\end{tabular}

Standardfeil i parentes, ${ }^{\star} p<0.05,{ }^{\star \star} p<0.01,{ }^{\star \star *} p<0.001$

Kilde: Sosiale medier-undersøkelsen 2016 


\section{Litteratur}

Bode, L. (2012). Facebooking it to the polls: A study in online social networking and political behavior. Journal of Information Technology \& Politics, 9, 352-369.

Boyd, D. (2011). Social network sites as networked publics. Affordances, dynamics and implications. I Z. Papacharissi (red.), A networked self. Identity, community and culture on social network sites. New York: Routledge.

Büchi, M., Just, N., \& Latzer, M. (2016): Modeling the second-level digital divide: A five-country study of social differences in Internet use. New Media \& Society, 18 (1): $2703-2722$.

Castells, M. (2009 [1996]). The Rise of the Network Society. The information age: economy, society and culture. Vol 1. 2nd ed. Oxford: Blackwell.

Converse P. E. (1972). Change in the American electorate. I A. Campbell \& P. E. Converse (red.), The Human Meaning of Social Change (pp. 261-337). New York: Russel Sage Found.

De Vreese, C., \& Boomgaarden, H. (2006). News, political knowledge and participation: The differential effects of news media exposure on political knowledge and participation. Acta Politica, 41, 317-341.

deSilver, D. (2014). Facebook is a news source for many, but only incidentally. Pew Research Center. http://www.pewresearch.org/fact-tank/2014/o2/o4/facebook-isa-news-source-for-many-but-only-incidentally/

Deutsch, K. (1961). Social mobilization and political development. American Political Science Review, 55, 793-515.

Eimhjellen, I. (2018) New Forms of Civic Engagement. Implications of Social Media on Civic Engagement and Organization in Scandinavia. I L. S. Henriksen, K. Strømsnes \& L. Svedberg (red.) Civic Engagement in Scandinavia. Volunteering, Informal help and Giving in Denmark, Norway and Sweden. Springer.

Eimhjellen, I. Steen-Johnsen, K., Folkestad, B., \& Ødegård, G. (2018). Changing Patterns of Volunteering and Participation. I B. Enjolras \& K. Strømsnes (red.) Scandinavian Civil Society and Social Transformations. Springer

Eimhjellen, I. (2014). From face-to-face to Facebook? Web technologies in Norwegian civil society. University of Bergen, Bergen.

Ekman, J., \& Amnå, E. (2012). Political participation and civic engagement: Towards a new typology. Human Affairs, 22, 283-300.

Enjolras, B., Karlsen, R., Steen-Johnsen, K., \& Wollebæk, D. (2013). Liker-Liker ikke: Samfunnsengasjement i en Facebook-tid. Oslo: CappelenDam.

Estelle's-Arolas, E. \& Gonza'lez-Ladro'n-de-Guevara. (2012). Towards an integrated crowdsourcing definition. Journal of Information Science, 38(2), 189-200.

Fisher, C. (1975a). The effect of urban life on traditional values. Social forces, 53(3), $420-432$. 
Fisher, C. (1975b). Toward a subcultural theory of urbanism. American Journal of Sociology, 84, 1319-1341.

Fortunati, L., \& Taipale, S. (2013). The diffusion and use of information and communication technologies and the city, 1996 to 2009. First Monday Peerrevieew journal of the internet, $18(11)$.

Gil de Zúñiga, H., Jung, N., \& Valenzuela, S. (2012). Social media use for news and individuals' social capital, civic engagement and political participation. Journal of Computer-Mediated Communication, 17(3), 319-336.

Haight, M., Quan-Haase, A., \& Corbett, B. (2014). Revisiting the digital divide in Canada: The impact of demographic factors on access to the internet, level of online activity, and social networking site usage. Information, Communication \& Society, $17(4)$, 503-519.

Hollander, B. A. (2008). Tuning out or tuning elsewhere? Partisanship, polarization, and media migration from 1998 to 2006. Journalism \& Mass Communication Quartely, 85(1), 23-40.

Holt, K., Shehata, A., Strömbäck, J., \& Ljungberg, E. (2013). The effects of news media attention and social media use on political interest and participation: Do social media function as Leveller? European Journal of Communication, 28, 19-34.

Kobayashi, T., \& Inamasu, K. (2015). The knowledge leveling effect of portal sites. Communication research, 42(4), 482-502.

McLeod, J. M., Daily, K., Guo, Z., Eveland, W. P., Jr., B., J, Yang, S., \& Wang, H. (1996). Community integration, local media use, and democratic processes. Communication research, 23(2), 179-209.

McLeod, J. M., Scheufele, D. A., \& Moy, P. (1999). Community, communication, and participation: The role of mass media and interpersonal discussion in local political participation. Political Communication, 16(3), 315-336.

Morozov, E. (2011) The Net delusion: The dark side of Internet freedom. New York: Public Affairs

Olsen, J. P., \& Sætren, H. (1980). Aksjoner og demokrati. Bergen: Universitetsforlaget.

Pasek, J., More, E., \& Romer, D. (2009). Realizing the social internet? Online social networking meets offline civic engagement. Journal of Information Technology \& Politics, 6(3-4), 197-215.

Prior, M. (2007). Post-broadcast democracy. How media choice increases inequality in political involvement and polarizes elections. New York: Cambridge University Press.

Sakariassen, H., Hovden, J. F., \& Moe, H. (2017). Bruksmønstre for digitale nyheter. Universitetet i Bergen.

Schnaiberg, A. (1971). The modernizing impact of urbanization: A causal analysis. Economic development and cultural change, 20(1), 80-104.

Skaletski, M., Galliers, R.D., Haughton, D., \& Soermekun, O. (2016). Exploring the predictors of the international digital divide. Journal of global information technology management, 19(1), 44-67. 
SSB. (2016). Dette er Norge 2016. Hva tallene forteller. Oslo/Kongsvinger: Statistisk sentralbyrå.

Tang, G., \& Lee, F. L. F. (2013). Facebook use and political participation: The impact of exposure to shared political information, connections with public political actors, and network structural heterogeneity. Social Science Computer Review, 31(6), 763-773.

Trilling, D., \& Schoenbach, K. (2013). Skipping current affairs: The non-users of online and offline news. European Journal of Communication, 28(1), 35-51.

Uslaner, E. M. (2005). Civic Engagement in America: Why People Participate in Political and Social Life.

Uslaner, E. M., \& Brown, M. (2005). Inequality, Trust, and Civic Engagement. American Politics Research, 33(6), 868-894. doi:10.1177/1532673X04271903

Van Aelst, P., Strömbäck, J., Aalberg, T., Esser, F., de Vreese, C., Matthes, J., \& Stanyer, J. (2017). Political communication in a high-choice media environment: a challenge for democracy? Annals of the International Communication Association, $41(1), 3-27$.

Van Deursen, A., \& van Dijk, J. (2014): The digital divide shifts to differences in usage. New Media \& Society, 16 (3): 507-526.

Van Dijk, J., \& Hacker, K. (2003). The digital divide as a complex and dynamic phenomenon. The Information Society, 19(4), 315-326.

Verba, S., \& Nie, N. H. (1972). Participation in America: Political Democracy and Social Equality. Chicago: University of Chicago Press.

Verba, S., Nie, N. H., \& Kim, J.-O. (1978). Participation and Political Equality: A Seven-Nation Comparison. Chicago: Chicago University Press.

Verba, S., Schlozman, K. L., \& Brady, H. E. (1995). Voice and equality: Civic voluntarism in American politics. Cambridge: Harvard University Press.

Wang, Y., \& Sun, J. (2013). Global diffusion of virtual social networks: A pyramid model of cultural, developmental and regulatory foundations. Journal of information Systems Applied Research, 6(1), 27-38.

Wei, L., \& Hindman, D. B. (2011). Does the digital divide matter more? Comparing the effects of new media and old media use on the education-based knowledge gap. Mass Communation and Society, 14, 216-235.

Wolfinger, R. E., \& Rosenstone, S. J. (1980). Who Votes? New Haven, CT: Yale University Press.

Wollebæk, D., \& Sivesind, K. H. (2010). Fra folkebevegelse til filantropi? I Xenos, M., Vromen, A., \& Loader, B. D. (2014). The great equalizer? Patterns of social media use and youth political engagement in three advanced democracies. Information, Communication \& Society, 17(2), 151-167.

Young, D. G. (2016). Humor and satire, political. The International Encyclopedia of Political Communication, $1-7$. 



\title{
Forholdet mellom online- og offline-deltakelse i frivillige organisasjoner
}

\author{
Bernard Enjolras
}

Institutt for samfunnsforskning

Kari Steen-Johnsen

Institutt for samfunnsforskning

\section{Audun Beyer \\ Institutt for samfunnsforskning}

\begin{abstract}
In this chapter the relationship between online and offline civic engagement. We look specifically at the effect of being a member of a Facebook group related to voluntary organizations or to different types of protest on offline membership in voluntary organization and offline volunteering. Using panel-data from a three-wave survey of the Norwegian population using the Internet we test three hypotheses about the relationship between online and offline civic engagement. According to the mobilizationhypothesis, online experience will enhance offline participation of those who are inactive. The crowding-out hypothesis predicts that, since those who are engaged offline will also be the one who are engaged online, increased online engagement will reduce offline engagement. Finally, the independence-hypothesis considers online and offline engagement as not related to each other. Our results show that, in Norway during the period 2012-2016, following Facebook-groups related to a voluntary organization or to different types of protest groups has an impact on offline membership in voluntary organizations, but not on voluntary work. An important exception, however, is that following a Facebook group related to a voluntary organization has a positive effect on offline volunteering in voluntary organization.
\end{abstract}

Keywords: online, offline, civic engagement, volunteering, voluntary organization, Facebook

Sitering av denne artikkelen: Enjolras, B., Steen-Johnsen, K., \& Beyer, A. (2018). Forholdet mellom online- og offline-deltakelse i frivillige organisasjoner. I B. Enjolras \& I. Eimhjellen (Red.), Fra kollektiv til konnektiv handling? Nye former for samfunnsengasjement og kollektiv handling i Norge (s. 101-126). Oslo: Cappelen Damm Akademisk. https://doi.org/10.23865/noasp.45.ch4 Lisens: CC BY-NC 4.0 


\section{Innledning}

Digitalisering og fremveksten av sosiale medier har siden årtusenskiftet ført med seg store endringsprosesser på ulike felter i samfunnet. På den ene siden gir sosiale medier mange flere muligheten til å skaffe seg informasjon om det som foregår i samfunnet, og til å engasjere seg. På den andre siden er det et spørsmål om de nye digitale mulighetene bidrar til at folk trekkes vekk fra viktige samfunnssaker og over i tidsfordriv og underholdning. I en innflytelsesrik tekst fra 2009 reiste Morozov spørsmålet om vi også er på vei inn i en tidsalder preget av «slacktivisme», det vil si en tid der folk slutter å engasjere seg i virkeligheten, og nøyer seg med å klikke «liker» for å vise sitt engasjement (Morozov, 2009). Morozovs argument er at denne typen engasjement verken er spesielt krevende eller særlig virkningsfullt, og at vi dermed risikerer et uengasjert, svekket demokrati. Hvilke konsekvenser får disse prosessene for samfunnsengasjement og deltakelse i frivillighet i Norge?

I den statsvitenskapelige litteraturen er det bred enighet om at politisk deltakelse og samfunnsengasjement er hjørnesteiner i et velfungerende demokrati (Verba, Schlozman \& Brady, 1995). Norge har sterke tradisjoner for samfunnsrettet deltakelse og frivillig arbeid, og et sterkt organisasjonsliv som bidrar til å organisere og mobilisere deltakelse i befolkningen (Arnesen mfl., 2016; Folkestad mfl., 2015). Det frivillige organisasjonslivet kan forstås som en velutbygd struktur for informasjon og kommunikasjon mellom medlemmer, frivillige og aktivister, på nasjonalt og lokalt nivå. Spørsmålet er hva som skjer når digitale kommunikasjonsstrukturer oppstår både på siden av og innenfor organisasjonslivet. Bidrar sosiale medier til å senke terskelen for mobilisering og engasjement slik at flere deltar, eller flyttes bare aktiviteten fra en offline sfære til en online sfære?

Mens offline engasjement typisk vil være karakterisert ved ansikttil-ansikt-samvær med andre personer, muliggjør digitale medier både koordinering, kommunikasjon og interaksjon som ikke nødvendigvis krever samvær, det vil si at de ikke behøver å finne sted i samme tid og rom. I dette kapitlet skal vi undersøke sammenhengen mellom det å engasjere seg i sosiale medier og engasjement offline. Mer presist spør vi om frivillig engasjement online fører til mer eller mindre involvering og deltakelse i 
offline aktiviteter. Vi fokuserer på frivillig arbeid og medlemskap i frivillige organisasjoner.

For å undersøke disse spørsmålene bruker vi en befolkningsrepresentativ spørreundersøkelse som har vært gjennomført i 2012, 2014 og 2016. Fordelen med denne undersøkelsen er at flere av respondentene har besvart undersøkelsen alle tre gangene. De utgjør dermed et såkalt panel. Dette gjør at vi kan si noe om utviklingen over tid, og kan undersøke om de som fulgte en organisasjon i sosiale medier i 2012, er blitt mer aktive også når det gjelder frivillige aktiviteter offline på et senere tidspunkt. En slik analyse av endringer som skjer med bare noen av respondentene i et panel, er særlig godt egnet for å undersøke de problemstillingene vi her er opptatt av.

Kapitlet starter med en teoretisk diskusjon om hva som kan forventes når det gjelder forholdet mellom online og offline samfunnsengasjement. Deretter presenterer vi dataene, metode og analysestrategier. I den empiriske delen gir vi først et beskrivende bilde av bruk av sosiale medier og hvordan det er knyttet til frivillig engasjement. Til slutt presenterer vi en analyse der vi benytter panelstrukturen i datamaterialet for å undersøke årsakssammenhenger mellom ulike typer av aktiviteter og engasjement.

\section{Digitale medier og samfunnsengasjement: kunnskapsstatus}

Utbredelsen av digitale kommunikasjonsnettverk har endret forutsetningene for samfunnsengasjement. I de senere årene har en rekke forskningsbidrag fokusert på forholdet mellom politisk engasjement og samfunnsengasjement både online og offline. Før vi presenterer hypotesene og tilnærmingen i denne studien, gir vi en kort oversikt over forskningen på feltet. Mye av denne har sitt opphav i USA.

Tidligere forskning viser at bruk av sosiale medier har en positiv effekt på samfunnsengasjement, selv om forskningen peker i forskjellige retninger når det gjelder årsaker, hvor omfattende slike effekter er, og hvilken form de har. I en studie gjennomført i USA fant Zhang mfl. (2010) at bruk av digitale medier var forbundet med økt samfunnsengasjement. Valenzuela mfl. (2009) fant at generell Facebook-bruk og bruk 
av Facebook-grupper også hadde en positiv effekt på folks samfunnsengasjement. Park mfl. (2009) fant at de som er med i Facebook-grupper, involverer seg for å tilfredsstille ulike behov, som behov for informasjon, sosialisering og underholdning. Denne bruken fremmer så økt samfunnsengasjement. En studie av Gil de Zúñiga mfl. (2012) viser at bruk av Facebook for å søke informasjon er positivt forbundet med samfunnsengasjement, selv om effekten er svak. Samlet viser altså mange studier at det er en positiv sammenheng mellom bruk av sosiale medier og samfunnsengasjement, men at den er ganske svak eller indirekte i noen tilfeller.

Flere studier har også undersøkt forholdet mellom bruk av sosiale medier og ulike former for politisk deltakelse. Disse studiene har sett på sammenhengen mellom online og offline deltakelse og engasjement, og også her er forskningen ofte fra USA. Her ser vi imidlertid blandede funn. Noen studier finner at generell Facebook-bruk er knyttet til økt online politisk aktivitet (Bode, 2012; Vitak, 2012), mens andre studier ikke finner slike sammenhenger (Gil de Zúñiga mfl., 2012; Skorisk \& Poor, 2013). Noen studier viser også at bruk av blogger og mikroblogger er positivt relatert til både online (Chan mfl., 2012; Gil de Zúñiga mfl., 2009; Lewis, 2010) og offline politisk engasjement (Gil de Zúñiga mfl., 2013).

Noen studier antyder likevel at generell bruk av sosiale medier ikke er knyttet til tradisjonell politisk deltakelse (Baumgartner \& Morris, 2010; Kushin \& Yamamoto, 2010; Zhang mfl., 2010). I tillegg er det ingen enighet om hvordan forholdet mellom generell Facebook-bruk og offline politisk deltakelse arter seg. Mens noen studier viser en positiv relasjon mellom online og offline deltakelse (Bode, 2012; Park mfl., 2009; Skorisk \& Poor, 2013), fant andre studier ingen sammenheng (Gil de Zúñiga mfl., 2012; Valenzuela mfl., 2009) eller til og med en svak negativ effekt (Vitak mfl., 2011). Forskningen er mer samstemt i at politisk bruk av sosiale medier viser et positivt forhold mellom å være med i for eksempel Facebook-grupper (Conroy mfl., 2012; Valenzuela mfl., 2009) og politisk engasjement på Facebook (Vitak mfl., 2011). Det ser altså ut til at hva man bruker sosiale medier til, har betydning for hvilken effekt denne bruken i sin tur har. 
Samlet sett er det altså vanskelig å trekke entydige konklusjoner fra litteraturen som har studert sammenhengene mellom politisk deltakelse og samfunnsengasjement online og offline. For det første er resultatene noen ganger motsigende: Noen studier finner en positiv sammenheng, mens andre ikke finner noen sammenheng eller en negativ effekt. For det andre er forskningslitteraturen preget av et stort mangfold i måten online engasjement er operasjonalisert på. Mens noen studier ser på forholdet mellom generell bruk av bestemte digitale plattformer som Twitter og Facebook, fokuserer andre på klar politisk bruk av disse plattformene. I tillegg er mange studier basert på tverrsnittsdata, som gjør påstander om årsakssammenhenger svært problematiske. Denne gjennomgangen av den eksisterende litteraturen understreker behovet for å studere forholdet mellom online og offline over tid for å kunne fastslå retningen på sammenhengen mellom online og offline deltakelse, samt behovet for å fokusere på online og offline aktiviteter som er tett knyttet til hverandre, istedenfor generell bruk av internettbaserte medier.

\section{Mobilisering, erstatning eller uavhengighet? Tre hypoteser om sammenhenger}

Som vist over er det fortsatt stor uenighet om hvilke konsekvenser de nye mediene har for politisk og sivilt engasjement (Wright, 2010). Likevel kan vi grovt sett skille ut tre rådende syn på hvordan sammenhengene mellom nye medier og ulike former for engasjement kan arte seg. Tilhengere av mobiliseringstesen hevder at internett og sosiale medier bidrar til å mobilisere nye grupper av individer ved å skape et rikt informasjonsmiljø (Dahlberg \& Siapera, 2007; Dahlgren, 2005). For tilhengere av erstatningstesen vil derimot tiden som brukes på Facebook og andre sosiale medier, føre til en nedgang i samfunnsengasjementet (Putnam, 200o). En tredje hypotese er at online aktiviteter er et supplement til offline aktiviteter heller enn at de forstyrrer hverandre som måter å utføre samfunnsengasjement på. I dette tilfellet vil ikke engasjement online ha effekter på deltakelse offline, fordi begge arenaer fyller ulike funksjoner, og muliggjør forskjellige handlinger og former for engasjement. Dermed supplerer 
de ulike kommunikasjonsformene hverandre snarere enn å erstatte hverandre (Enjolras mfl., 2013; Wellman mfl., 2001).

Den første hypotesen - mobiliseringshypotesen - bygger på en antagelse om at erfaringer online vil generere offline deltakelse for de som ikke allerede har vært aktive. Fordi online engasjement krever mindre enn offline engasjement, fungerer det som en læringsarena for å utvikle ferdigheter for videre offline engasjement. Denne hypotesen ser altså på nye digitale medier som viktige verktøy for å engasjere enda flere enn tidligere til deltakelse og engasjement i samfunnsliv. Online engasjement vil føre til at folk som tidligere ikke engasjerte seg fordi terskelen til offline engasjement var for høy, ledes inn i engasjement og deltakelse på en enklere måte. En viktig test av denne hypotesen vil være om man kan observere forskjeller mellom dem som har engasjert seg online eller ikke, når det gjelder hvorvidt de senere også velger å engasjere seg offline. Hvis hypotesen skal styrkes, bør man kunne observere at sannsynligheten for å engasjere seg offline øker mer for de som tidligere har engasjert seg online, enn for de som ikke har det. Her blir panelstrukturen i dataene svært viktig. Når det gjelder deltakelse i frivillige organisasjoner (som medlem eller frivillig) har en rekke studier vist at friville organisasjoner har tatt i bruk sosiale medier for å bygge opp nettverksrelasjoner (Briones, Kuch, Liu \& Jin, 2011; Lovejoy \& Saxton, 2012). Disse studiene viser at sosiale medier åpner nye muligheter for organisasjoner til både å kommunisere med sitt publikum og til å mobilisere nye medlemmer og frivillige. Organisasjoner med et stort antall medlemmer eller følgere i sosiale medier vil kunne rekruttere og mobilisere nye medlemmer og frivillige. Uformelle og personlige nettverksrelasjoner har vist seg å være sterkt knyttet til organisasjoners ressursmobilisering og rekruttering av frivillige (Eng, Liu \& Sekhon, 2012).

Erstatningshypotesen snur på det, og hevder at virkeligheten offline reproduseres online (Norris, 2001). Det vil si at de som allerede er samfunnsengasjerte, kunnskapsrike og aktive offline, vil være de samme som bruker internett for samfunnsmessige formål. Siden personer som er samfunnsengasjerte, har begrenset med tid, forventes det at økt engasjement online vil gå på bekostning av offline engasjement. Hvis denne erstatningstesen er riktig, bør online engasjement forventes å føre til redusert offline engasjement. I tillegg, gitt at individene har begrenset tid 
som de kan bruke på ulike formål, kan økt tidsbruk på sosiale medier gå på bekostning av offline engasjement i frivillige organisasjoner. En tredje grunn til at online engasjement muligens kan erstatte offline deltakelse, er knyttet til teknologien. I Bowling alone presenterer Robert Putnam (2000) omfattende bevis på erosjon av sosial kapital i etterkrigsårenes USA. Putnam anser at det er flere årsaker som kan ha bidratt til denne utviklingen, for eksempel press på tid og penger. Men det er endringer i teknologi og media, spesielt økningen i fjernsynsunderholdning som Amerikas viktigste kilde til fritidsaktivitet, Putnam peker ut som den store skyldige og som ansvarlig for erosjonen av sosial tilknytning og samfunnsengasjement. Ifølge Putnam har privatisering av fritiden ført til borgernes tilbaketrekning fra det offentlige liv. Sosiale medier kan muligens føre med seg en tilsvarende form for privatisering ved å gi en opplevelse av sosialitet og sosiale nettverk uten behov for offline interaksjoner, og ved å øke tilbudet av online underholdnings- og tidsfordrivsmuligheter.

Den siste hypotesen - uavhengighetshypotesen - påstår i stedet at de to formene for engasjement vil utvikle seg uavhengig av hverandre fordi de fyller ulike behov og funksjoner for borgerne. I dette tilfellet vil det være en arbeidsdeling mellom ulike former av online og offline aktiviteter uten at de påvirker hverandre. Vi kan ikke undersøke denne hypotesen direkte gjennom våre data, men tar den likevel med som et logisk alternativ som kan diskuteres til slutt.

\section{Data og metode}

De empiriske analysene i dette kapitlet er basert på data fra forskningsprosjektet Social Media in the Public Sphere (SMIPS). Disse dataene består av en undersøkelse som ble gjentatt tre ganger, i 2012, 2014 og 2016. Utvalgene er representative for befolkningen av internettbrukere trukket fra Kantar TNS' internettpanel. Datainnsamlingsmetoden ekskluderer dermed den delen av befolkningen som ikke bruker internett, fra utvalget. Dette utgjør imidlertid en svært liten andel av befolkningen i Norge, ettersom tilgangen til og bruken av internett er spesielt høy i Norge (ifølge Statistisk sentralbyrå (2018) bruker 96 prosent av befolkningen mellom 16 
og 79 år internett, og 80 prosent av befolkningen i de samme aldersgruppene bruker sosiale medier). Datainnsamlingen ble først gjennomført i $2012(N=5019)$, og gjentatt i $2014(N=5677)$ og $2016(N=5054)$. Unders $\varnothing-$ kelsene har en panelstruktur, og på hvert datapunkt ble alle respondenter fra tidligere runder kontaktet på nytt. For å belyse våre problemstillinger bruker vi både de representative befolkningsutvalgene for hvert tidspunkt og panelet, som består av 822 personer som har svart på alle tre undersøkelsene i 2012, 2014 og 2016.

For å estimere effekten av bruk av sosiale medier på offline deltakelse i frivillige organisasjoner og frivillig arbeid undersøker vi på hvilken måte medlemskap i frivillige organisasjoners grupper eller sider på Facebook påvirker offline medlemskap i frivillige organisasjoner samt frivillig arbeid. Selv om man kan argumentere for at medlemskap i slike grupper utgjør en svært løs form for tilknytning, gir de mulighet til å motta informasjon fra organisasjonen og indikerer en interesse for organisasjonen det gjelder, og det kan tenkes som et første steg $\mathrm{i}$ å få en mer formell, offline tilknytning til organisasjonen.

Medlemskap i frivillige organisasjoners grupper på Facebook er målt gjennom spørsmålet «Hva slags grupper er du medlem av, og hvilke typer sider følger du på Facebook?», der respondentene kunne merke hvilke Facebook-grupper de var medlemmer av blant 14 alternativer, inkludert «grupper/sider knyttet til frivillige organisasjoner», «grupper/sider knyttet til lokal protestgrupper», «grupper/sider knyttet til nasjonal protestgrupper», og «grupper/sider knyttet til internasjonale protestgrupper». Offline medlemskap i frivillige organisasjoner er operasjonalisert med variabelen «antall medlemskap i frivillige organisasjoner», som summerer svarene på spørsmålet «Er du medlem i noen av de følgende typene organisasjoner?», der respondentene kunne krysse av for de relevante alternativene blant ni organisasjonskategorier. ${ }^{1}$

$1 \quad$ Idrettslag, Kultur, musikk eller hobbyforening, Sosial og humanitær organisasjon, Politisk parti, Andre politisk orienterte organisasjoner (f.eks. miljøvern, internasjonal solidaritet), Velforeninger, grendelag og borettslag, Fagforening, yrkes- eller bransjeorganisasjon, Religions- eller livssynsorganisasjon, og Andre 
Tid brukt på frivillig arbeid er målt på en fempunktskala, der minimum var mindre enn en halvtime, maksimum mer enn 5 timer. $^{2}$

I analysene kontrollerer vi også for et bredt sett med bakgrunnsvariabler: ${ }^{3}$ Ved å kontrollere effekten av disse kan vi utelukke om en mulig effekt av online deltakelse på offline deltakelse skyldes bakgrunnsegenskapene til respondentene. Tidligere forskning fra Norge (Enjolras mfl., 2013) viser at både alder, utdanning og kjønn henger sammen med bruk av sosiale medier, og at det er unge, høyt utdannede og mannlige respondenter som har høyest bruk av sosiale medier. Mer generelt har også tidligere forskning vist at deltakelse i sivilsamfunnet er sterkt forbundet med utdanning (Almond \& Verba, 1993).

For å vurdere effekten online deltakelse har på offline deltakelse bruker vi en analyse av panelstrukturen i dataene. ${ }^{4}$ For å undersøke betydningen av ulike typer sosiale medier-bruk og medietidsbruk for offline frivillig engasjement konstruerer vi tre indekser som fanger opp tre mulige formål for sosiale medier-bruk: samfunnsinteresse, hverdagsinteresse og sosialiseringsinteresse. Disse tre typene sosiale medier-bruk er konstruert på bakgrunn av en faktoranalyse av 16 alternative mulige aktiviteter på Facebook (se tabell A4 i Appendiks). Medietidsbruk-variabelen summerer tiden brukt daglig på ulike medier: TV, radio, aviser, online aviser, sosiale medier, og annen nettbruk.

Mindre enn en halvtime, Mellom en halvtime og en time, Mellom en og to timer, 3-5 timer, Mer enn 5 timer, som utgjorde svaralternativet for spørsmålet: «Omtrent hvor mye tid har du brukt på slikt frivillig arbeid en vanlig uke?»

3 Alder, kjønn, utdanning, husstandsinntekt og antall barn under 15 år.

4 Paneldata refererer til datasett der vi har observasjoner på det samme individet over flere perioder. Paneldata- regresjon gjør det mulig å estimere effekten av endringer i uavhengige variabler på den avhengige variabelen. Det finnes to hovedmodeller for lineær regresjon med paneldata: faste effekter og tilfeldige effekter. Fasteeffekt-modellen kontrollerer for uobserverte forskjeller mellom individer som ikke varierer over tid. Tilfeldige effekter-modellen antar at uobserverte forskjeller mellom individer er tilfeldig fordelte. For å velge hvilken modell som er best tilpasset analysen, er det vanlig å sammenligne de to modellene ved hjelp av Hausmantest. Vår Hausmantest, som tester validiteten av en tilfeldige effekter-modell sammenlignet med en faste effekter-modell, er ikke signifikant. Den tilfeldige effekter-modellen er dermed konsistent og tilpasset for våre analyser. 


\section{Online og offline engasjement i frivillige organisasjoner fra 2012 til 2016}

Før vi ser på sammenhengen mellom online og offline engasjement, vil vi undersøke hvordan hovedvariablene som inngår i analysene, har utviklet seg over tid, og hvordan de er fordelt med hensyn til sosioøkonomiske kjennetegn. Dette gir oss et overblikk over utviklingen, og noen indikatorer om hvorvidt det for eksempel har skjedd store endringer i offline engasjement i den perioden der online engasjement har vokst frem.

Facebook-bruken var høy blant våre respondenter allerede i 2012 (95 prosent av respondentene), og at den har holdt seg minst like høy i årene etter dette. For Twitter observerer vi en økning i andelen som hadde en slik konto, fra 20 prosent i 2012 til 30 prosent i 2016.

For å fange opp graden av frivillig engasjement online og offline bruker vi tre variabler: antall medlemskap i frivillige organisasjoner, tid brukt på frivillig arbeid per uke, og medlemskap i frivillige organisasjoners grupper på Facebook. Figur 1 og 2 viser utviklingen fra 2012 til 2016 i befolkningsutvalget.

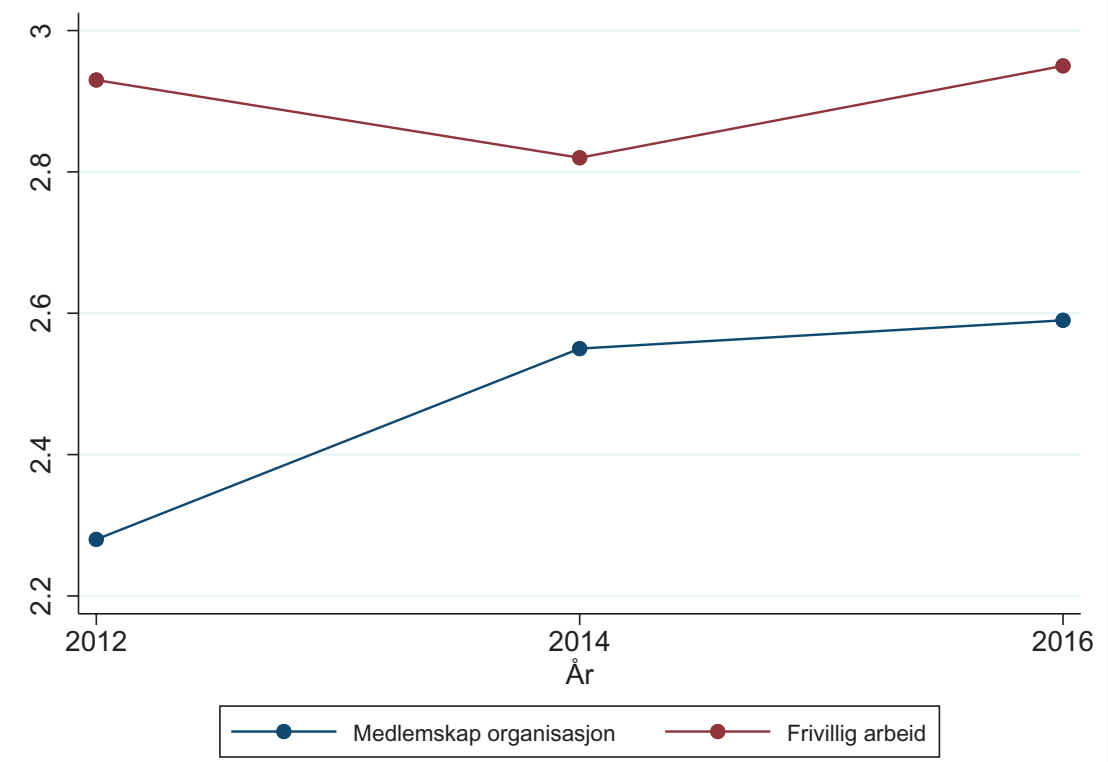

Figur 1: Frivillig engasjement online i perioden 2012-2016. Befolkningsutvalg: Gjennomsnittlig antall medlemskap i frivillige organisasjoner og gjennomsnittlig tidsbruk til frivillig arbeid i uken. 


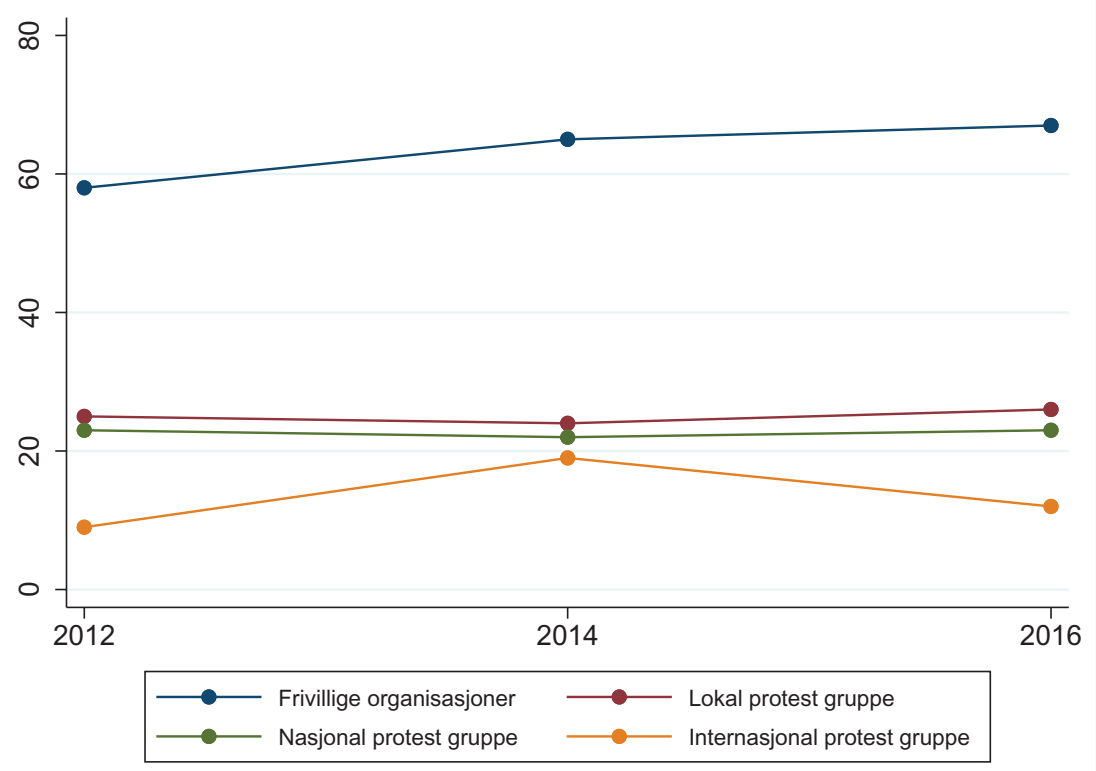

Figur 2: Frivillig engasjement online i perioden 2012-2016 (befolkningsutvalg): Andel som har minst ett medlemskap i ulike Facebook-grupper.

Utviklingen i befolkningsutvalgene og i panelet har vært identisk i perioden 2012-2016. Det gjennomsnittlige antallet medlemskap i frivillige organisasjoner på Facebook litt høyere i befolkningsutvalgene enn den er i panelet, mens det gjennomsnittlige antallet timer frivillig arbeid er høyere i panelet enn i befolkningsutvalgene. På figur 1 og 2 ser vi at offline former for frivillig engasjement, medlemskap og frivillig innsats har økt litt i perioden, men hovedbildet ser ut til å være preget av stabilitet, både når det gjelder offline og de fleste former for online engasjement. Det gjennomsnittlige antallet medlemskap i frivillige organisasjoner holder seg relativt stabilt i perioden. Det samme gjør tid brukt på frivillig arbeid, til tross for en liten nedgang i 2014. Samlet sett antyder denne oversikten at offline engasjement kanskje ikke er blitt påvirket så mye av variasjoner i online former for tilknytning.

Et viktig spørsmål knyttet til befolkningens samfunnsengasjement er hvem det er som deltar, og om det finnes store ulikheter basert på kjønn, utdanning eller inntekt. En omfattende litteratur diskuterer hvorvidt digitale medier opphever sosial ulikhet i deltakelse, eller om 
konsekvensen tvert imot er nye digitale skillelinjer (Eimhjellen \& Ljunggren, 2017; Norris, 2001). Selv om dette ikke er et hovedtema for oss i dette kapitlet, mener vi likevel det hører til bildet kort å berøre det her. Analysene våre viser at deltakelse $\mathrm{i}$ frivilligheten både offline (antall medlemskap i frivillige organisasjoner og tidsbruk til frivillig arbeid) og online (medlemskap i frivillige organisasjoners Facebook-gruppe og Facebook protestgrupper) i noen grad varierer med ulike sosioøkonomiske kjennetegn (Tabell A.1 i Appendiks). Antallet medlemskap i frivillige organisasjoner og deltakelse i Facebook-grupper knyttet til frivillige organisasjoner eller protestgrupper øker med både utdanning og inntekt. Tidsbruk til frivillig arbeid er derimot i liten grad påvirket av utdannings- og inntektsnivå. Når det gjelder medlemskap, ser dermed ikke fremveksten av sosiale medier ut til å redusere ulikhet, men heller til å reprodusere den. Vi finner ingen signifikante forskjeller mellom menn og kvinner.

\section{Sammenhengen mellom online og offline aktivitet - mobilisering eller erstatning?}

Oversikten over utviklingen i engasjement online og offline mellom 2012 og 2016 viser altså hovedsakelig stabilitet, men også noen interessante endringer. I neste del av analysen skal vi undersøke nærmere hvorvidt det er en sammenheng mellom deltakelse i online og offline aktiviteter, og om online aktivitet svekker eller styrker offline aktivitet. Analysens hensikt er å teste de to hypotesene som ble presentert tidligere i kapitlet, nemlig mobiliseringstesen og erstatningshypotesen. Ifølge mobiliseringshypotesen vil deltakelse i online frivillige aktiviteter føre til økt deltakelse i offline aktiviteter. Ifølge erstatningshypotesen vil online engasjement føre til mindre offline deltakelse i frivillige aktiviteter.

For å undersøke disse to hypotesene vil vi studere hvilken effekt medlemskap i frivillige grupper på Facebook har på tid brukt til offline frivillig innsats og medlemskap i frivillige organisasjoner. Vi undersøker først hvert år (2012, 2014, og 2016) for seg ved hjelp av tverrsnittsdata som er representative for befolkningen. Deretter bruker vi paneldata for perioden 2012-2016 og en analyse som ser på endringer over tid. Med en slik 
modell kan vi se om og i hvilken retning endringer i online deltakelse fra 2012 til 2016 påvirker offline deltakelse. 5

Tabell 1 og 2 viser resultatene av analysen av sammenhengen mellom medlemskap i grupper på Facebook knyttet til frivillige aktiviteter og henholdsvis offline medlemskap og frivillig arbeid.

Tabell 1: Lineær regresjon: Effekt av medlemskap i en frivillig organisasjonsgruppe (online), og ulike protestgrupper på Facebook, på tid brukt til frivillig arbeid og antall medlemskap i frivillige organisasjoner offline. Befolkningsutvalg i 2012, 2014, og 2016.

\begin{tabular}{|l|l|l|l|l|l|l|}
\hline & \multicolumn{2}{l|}{$\begin{array}{l}\mathbf{2 0 1 2} \\
(\mathbf{N}=\mathbf{5 0 1 9})\end{array}$} & \multicolumn{2}{l|}{$\begin{array}{l}\mathbf{2 0 1 4} \\
\mathbf{( N = 5 6 7 7 )}\end{array}$} & \multicolumn{2}{l|}{$\begin{array}{l}\mathbf{2 0 1 6} \\
(\mathbf{N}=5054)\end{array}$} \\
\hline & Org. med. & Friv. arb. & Org. med. & Friv. arb. & Org. med. & Friv. arb. \\
\hline $\begin{array}{l}\text { Friv.org. } \\
\text { Facebook- } \\
\text { gruppe }\end{array}$ & $.826^{\star \star \star}$ & $.149^{\star \star}$ & $.960^{\star \star \star}$ & $.240^{\star \star}$ & $1.006^{\star \star \star}$ & $-.213^{\star \star \star}$ \\
\hline $\begin{array}{l}\text { Facebook lokal } \\
\text { protestgruppe }\end{array}$ & $.514^{\star \star \star}$ & .008 & $.622^{\star \star \star}$ & .080 & $.653^{\star \star \star}$ & .030 \\
\hline $\begin{array}{l}\text { Facebook nasj. } \\
\text { protestgruppe }\end{array}$ & $.595^{\star \star \star}$ & .047 & $.721^{\star \star \star}$ & -000 & $.770^{\star \star \star}$ & -.064 \\
\hline $\begin{array}{l}\text { Facebook int. } \\
\text { protestgruppe }\end{array}$ & $.700^{\star \star \star}$ & -.010 & $.756^{\star \star \star}$ & $.231^{\star \star}$ & $.932^{\star \star \star}$ & .062 \\
\hline
\end{tabular}

${ }^{\star * \star} p<0.01,{ }^{\star \star} p<0.05,{ }^{*} p<0.1$

Note: Utdanning, kjønn, husholdsinntekt, antall barn under 15 år og alder inngår også i modellene, men er utelatt her for å gjøre tabellen enklere å lese. Se Tabell A.2, A3 og A4 i Appendiks for detaljerte modeller.

Tabell 1 viser regresjonskoeffisienter som måler effekten av online deltakelse i en frivillig Facebook-gruppe på antall organisasjonsmedlemskap og antall timer frivillig arbeid for hele befolkningen i årene 2012, 2014, og 2016 (se Appendiks A2, A3, og A4 for fullstendige regresjonsanalyser). Resultatene er konsistente på tvers av årene og viser at online deltakelse er positivt relatert til organisasjonsmedlemskap og frivillig arbeid, med unntak av online deltakelse i internasjonale protestgrupper, som er negativt assosiert med organisasjonsmedlemskap og frivillig arbeid. Dette tyder på at online deltakelse har en mobiliserende effekt. Likevel er det vanskelig å fastslå om det er online deltakelse som fører til offline deltakelse eller omvendt, bare ved hjelp av tverrsnittsdata. Ved å bruke

5 Når det gjelder offline deltakelse i demonstrasjoner og aksjoner, bruker vi en logistisk modell fordi den avhengige variabelen er dikotom. 
paneldata kan vi derimot undersøke nærmere om det finnes en mobiliserende effekt av online deltakelse på offline deltakelse.

Tabell 2: Panelregresjon (random effects): Effekt av medlemskap i en frivillig organisasjonsgruppe, og ulike protestgrupper på Facebook, på tid brukt til frivillig arbeid og antall medlemskap i frivillige organisasjoner $(N=822)$.

\begin{tabular}{|l|l|l|}
\hline & Organisasjonsmedlemskap & $\begin{array}{l}\text { Frivillig } \\
\text { arbeid }\end{array}$ \\
\hline Friv.org. Facebook-gruppe & $.897^{\star \star \star}$ & $.1649^{\star \star \star}$ \\
\hline Facebook Lokal protestgruppe & $0.558^{\star \star \star}$ & 0.032 \\
\hline Facebook Nasj. protestgruppe & $0.654^{\star \star \star}$ & 0.028 \\
\hline Facebook Int. protestgruppe & $0.769^{\star \star \star}$ & $0.129^{\star}$ \\
\hline
\end{tabular}

${ }^{\star \star \star *} p<0.01,{ }^{\star \star} p<0.05,{ }^{\star} p<0.1$

Note: Utdanning, kjønn, husholdsinntekt, antall barn under 15 år og alder inngår også i modellene, men er utelatt her for å gjøre tabellen enklere å lese. Se Tabell A.5 i Appendiks for detaljerte modeller.

Tabell 2 viser resultatene fra panelanalysen. Tabellens fire hovedkolonner viser effekten på offline organisasjonsmedlemskap og frivillig arbeid av å følge Facebook-grupper for 1) en frivillig organisasjon, 2) en lokal protestgruppe, 3) en nasjonal protestgruppe og 4) en internasjonal protestgruppe. Signifikante sammenhenger er markert med stjerne.

Vi ser en tydelig en todeling i resultatene, der det å følge Facebookgrupper har en effekt på offline organisasjonsmedlemskap, men ikke på frivillig arbeid. Et viktig unntak er likevel at det å følge en Facebook-gruppe knyttet til en frivillig organisasjon har en positiv effekt på frivillig arbeid. Nærmere bestemt øker antall organisasjoner en er medlem av, med medlemskap i en Facebook-gruppe, uavhengig av om det dreier seg om Facebook-gruppen til en frivillig organisasjon eller en lokal eller nasjonal protestgruppe. Vi finner tilsvarende resultater for Facebook-grupper knyttet til internasjonale protestgrupper (se Tabell A.5 i Appendiks). Resultatene viser dermed at medlemskap i ulike Facebook-grupper knyttet til frivillige organisasjoner og protestorganisasjoner har en mobiliserende effekt på offline medlemskap i frivillige organisasjoner.

Når det gjelder frivillig arbeid, viser resultatene at endring i medlemskap i en Facebook-gruppe knyttet til en protestgruppe ikke påvirker tid brukt til frivillig innsats. Det gjør derimot deltakelse i en Facebook-gruppe knyttet til en frivillig organisasjon. Med andre ord gjør ikke medlemskap i 
en Facebook-gruppe knyttet til en protestgruppe at det er mer sannsynlig at man deltar i frivillig arbeid i offline organisasjoner, men det ser heller ikke ut til at det å følge Facebook-grupper knyttet til en protestgruppe erstatter frivillig aktivitet. På dette området virker det som om de to typene aktiviteter er uavhengig av hverandre. Et interessant funn er likevel at det å være medlem i en Facebook-gruppe knyttet til en frivillig organisasjon fører til at det er mer sannsynlig at man deltar i frivillig arbeid. I dette tilfellet virker online medlemskap mobiliserende. Medlemskap i en Facebook-gruppe knyttet til en frivillig organisasjon eller en protestgruppe har en mye sterkere effekt på organisasjonsmedlemskap enn på frivillig arbeid.

Resultatene i Tabell 2 er intuitivt meningsfulle, i den forstand at medlemskap eller støtte til protestgrupper online ikke nødvendigvis er knyttet til frivillig arbeid for den gruppen eller organisasjonen som står bak denne gruppen. Samtidig virker det rimelig at deltakelse i en frivillig organisasjons gruppe på Facebook øker sannsynligheten både for å være medlem av denne organisasjonen og for å jobbe mer frivillig. Selv om forskningen viser at frivillige organisasjoner i utgangspunktet var sent ute med å ta i bruk digitale medier (se f.eks. Eimhjellen, 2014), er en stor andel av norske nasjonale frivillige organisasjoner nå på Facebook (se Beyer \& Steen-Johnsen i denne boken). Mange av disse organisasjonene vil ha gode koblinger mellom sin Facebook-side og ordinære web-sider, og de som følger Facebook-gruppen, vil dermed både kunne få informasjon og en bro til sider som stimulerer til å tegne medlemskap. Å tegne medlemskap kan også i stor grad være en nettbasert aktivitet. Selv om frivillig arbeid i mange tilfeller krever en konkret tilstedeværelse i offline aktiviteter lokalt, virker det som om online deltakelse fører til økt frivillig innsats offline. I tillegg foregår en del frivillig arbeid online, uten at vi har kunnet gjøre rede for det her. Fra andre studier vet vi at rundt 20 prosent oppgir at deler av det arbeidet de gjør for en frivillig organisasjon, foregår online (Eimhjellen \& Ljunggren, 2017, s. 67), og 4,5 prosent oppgir å ha gjort rent virtuelt frivillig arbeid (Folkestad, Christensen, Strømsnes, \& Selle, 2015). Det skal likevel understrekes at påvirkningen fra online til offline aktivitet, som vi analyserer i dette kapitlet, også kan tenkes å skje gjennom en allmenn bevisstgjøring om frivillige organisasjoners aktiviteter, rolle og betydning. 


\section{Konklusjon}

Vi begynte dette kapitlet med spørsmålet om hvorvidt sosiale medier bidrar til å svekke eller styrke deltakelse og samfunnsengasjement i Norge, spesielt med henblikk på deltakelse i frivillige organisasjoner. To hypoteser ble stilt opp mot hverandre, mobiliseringshypotesen og erstatningshypotesen. Ifølge den første kan samfunnsrettet deltakelse i sosiale medier bidra til mer deltakelse også i offline organisasjoner og aktiviteter. Ifølge erstatningshypotesen vil det derimot være slik at jo mer man engasjerer seg online, jo mindre kapasitet og motivasjon blir det igjen til å delta i offline aktiviteter.

Vår strategi for å undersøke disse problemstillingene har vært å analysere forholdet mellom medlemskap i frivillighetsrelaterte grupper på Facebook og frivillig arbeid og organisasjonsmedlemskap. Studien vår skiller seg fra eksisterende studier ved å undersøke bestemte politiske og frivillige aktiviteter både online og offline, ikke generell bruk av digitale medier. I tillegg bygger våre analyser på paneldata i en fireårsperiode som egner seg for analyse av årsakssammenhenger.

Basert på analysen i dette kapitlet kan vi konkludere med at på tross av at effekten av online samfunnsengasjement på offline frivillige aktiviteter er differensiert, virker online engasjement mest av alt mobiliserende for offline engasjement. Våre resultater gir dermed støtte til mobiliseringshypotesen når det gjelder deltakelse i frivillighetsrelaterte grupper på Facebook. Et unntak er effekten av online deltakelse i protestgrupper på Facebook på frivillig arbeid. Å følge slike protestgrupper på Facebook ser ikke ut til å ha effekt på aktiviteter offline. En mulig grunn kan være at disse gruppene ikke mobiliserer til frivillig arbeid i noen særlig grad. Digitale medier kan kanskje heller legge til rette for enklere informasjonsformidling og koordinering som ikke nødvendigvis innebærer offline organisering og fysisk oppmøte.

En mulig inngang til å diskutere den utviklingen vi har beskrevet her, er gitt gjennom Bennett og Segerbergs (2012) skille mellom to handlingslogikker: kollektiv og konnektiv handling. Kollektiv handling representerer tradisjonelle organisasjonsformer, og krever vanligvis organisatoriske ressurser samt tilstedeværelsen av organisatoriske strukturer, ledelse og utvikling av felles forståelsesrammer. For Bennett og Segerberg (2012) 
er altså kollektiv handling knyttet til hierarkiske institusjoner og medlemsgrupper der en felles kollektiv identitet er avgjørende. Den andre handlingslogikken, konnektiv handling, er basert på digitale medier som organiseringsagent og på selvorganiserende nettverk. I den nye konnektive handlingslogikken er formelle organisasjoner og gruppebånd mindre sentrale. Koordinering av kollektiv handling i disse nettverkene foregår gjennom digitale teknologier og krever ikke sterk organisatorisk kontroll eller felles kollektiv identitet. Perspektivet knyttet til konnektiv handling ser for seg at dette i økende grad vil kjennetegne ulike former for engasjement i politikk og i sivilsamfunnet.

Våre funn i dette kapitlet understreker at online kommunikasjon og koordinering er i ferd med å få betydning for organiseringen av samfunnsengasjement i det norske sivilsamfunnet. Dette kunne peke i retning av at vi ser fremveksten av konnektiv handling i Bennett og Segerbergs forstand. Samtidig er det interessant å merke seg koblingen mellom medlemskap i Facebook-grupper og medlemskap i tradisjonelle, offline organisasjoner. Dette er en indikasjon på at tradisjonelle organisasjoner i stor grad spiller en rolle i å organisere ulike former for samfunnsengasjement, og at de tar i bruk online medier som et verktøy i dette. I den grad folk kobler seg til slike organisasjoner, er det også et tegn på at tradisjonelle kollektive identiteter, som krever at deltakerne aksepterer et visst felles ideologisk fundament, også overlever i den nye tid. Våre data gir oss verken mulighet til å undersøke om de Facebook-gruppene folk er medlem av, er knyttet til tradisjonelle eller mer nettverkspregede organisasjoner, eller til å vurdere hvorvidt de som deltar, føler seg som del av en kollektiv identitet eller ikke. Vår antagelse er likevel at dataene fanger både kollektive og konnektive former for handling.

I det store og hele ser vi ingen tegn til svekkelse av samfunnsengasjement, verken online eller offline, i den fireårsperioden som vi har undersøkt. I tillegg er det et viktig poeng at engasjement på Facebook i hovedsak virker mobiliserende for de formene for offline samfunnsengasjement som ble analysert. Utbredelsen av internettbaserte medier undergraver dermed ikke sivilsamfunnets rolle som arena for samfunnsengasjement. Med internettbaserte medier har sivilsamfunnet fått nye kanaler for mobilisering av potensialet for engasjement. 


\section{Referanser}

Anduisa, E., Jensen, M. J., \& Jorba, L. (2012). Digital media and political engagement worldwide. Cambridge: Cambridge University Press.

Arnesen, D., Sivesind, K. H., \& Gulbrandsen, T. J. (2016). Fra medlemsbaserte organisasjoner til koordinert frivillighet? Det norske organisasjonssamfunnet fra 1980 til 2013. Rapport: 2016:05, Oslo: Senter for forskning på sivilsamfunn og frivillig sektor.

Bakardjieva, M. (2015). Do clouds have politics? Collective actors in social media land. Information, Communication \& Society, 18(8): 983-990.

Baumgartner, J. C., \& Morris, J. S. (2010). MyFaceTube politics: Social networking web sites and political engagement of young adults. Social Science Computer Review 28(1): 24-44.

Bennet, W. L. (2008). Changing citizenship in the digital age. I W. L. Bennet (Red.) How digital media can engage youth. Cambridge: MIT Press, s. 1-24.

Bennett, W. L., \& Segerberg, A. (2012). The logic of connective action. Information, Commuication \& Society, 15(5): 739-768.

Bode, L. (2012). Facebooking it to the polls: a study in online social networking and political behavior. Journal of Information Technology \& Politics, 9(4): 352-369.

Bonfadelli, H. (2002). The Internet and knowledge gaps: A theoretical and empirical investigation. European Journal of Communication, 17, 65-84.

Boulianne, S. (2009). Does Internet Use Affect Engagement? A Meta-Analysis of Research. Political Communication, 26(2): 193-211.

Boulianne, S. (2011). Stimulating or Reinforcing Political Interest: Using Panel Data to Examine Reciprocal Effects Between News Media and Political Interest. Political Communication 28(2): 147-162.

Boulianne, S. (2015). Social media use and participation: A meta-analysis of current research. Information, Communication and Society, 18(5): 524-538.

Boyd, D. (2011). Social network sites as networked publics: Affordances, dynamics and implications. I Papacharissi, Z. (Red.) A Networked Self: Identity, Community and Culture on Social Network Sites. New York: Routledge, s. 39-58.

Briones, R. L., Kuch, B., Liu, B., \& Jin, Y. (2011). Keeping up with the digital age: How the American Red Cross uses social media to build relationships. Public Relations Review, 37: 37-43.

Chan, M., Wu, X., \& Hao Y. Q. (2012). Microblogging, online expression, and political efficacy among young Chinese citizens: The moderating role of information and entertainment needs in the use of Weibo. Cyberpsychology. Behavior and Social Networking 15(7): 345-349.

Conroy, M, Feezell, J. T., \& Guerrero, M. (2012). Facebook and political engagement: a study of online political group membership and offline political engagement. Computers in Human Behavior 28(5): 1535-1546. 
Dahlberg, L., \& Siapera, E. (2007). Radical Democracy and the Internet. New York: Palgrave Macmillan.

Dahlgren, P. (2005). The Internet, public spheres, and political communication: Dispersion and deliberation. Political Communication 22(2): 147-162.

Dalton, R. (1998). Citizen politics in western democracies. New Jersey: Chatham.

Dalton, R. (2006). Citizen politics: Public opinion and political parties in advanced western democracies. CQ Press: Washington.

Dalton, R. (2008) The good citizen: How a younger generation is reshaping American politics. Washington: CQ Press.

DiMaggio, P., Hargittai, E., Celeste, C., \& Shafer, S. (2004). Digital inequality: From unequal access to differentiated use. I K. Neckerman (Red.), Social Inequality. New York: Russell Sage Foundation, pp.355-40o.

Earl, J., Hunt, J., Garrett, R.K., \& Dal, A. (2015). New technologies and social movements. I D. Della Porta, \& M. Diani (Reds.) The Oxford Handbook of Social Movements. Oxford: Oxford University Press.

Eng, T., Liu, C., \& Sekhon, Y. (2012). The role of relationally embedded network ties in resource acquisition of British nonprofit organizations. Nonprofit and Voluntary Sector Quarterly, 41: 1092-1115.

Eimhjellen, I., Wollebæk, D., \& Strømsnes, K. (2014). Associations online. Barriers to using web-based communication in voluntary organizations. Voluntas International Journal of Voluntary and Nonprofit Organizations, 25(3): 730-753.

Eimhjellen, I., \& Ljunggren, J. (2017). Kollektiv handling i digitale medier: Nye digitale skiller? Oslo: Senter for forskning på sivilsamfunn og frivillig sektor.

Eimhjellen, I. S. (2014). From face-to-face to Facebook: Web technologies in Norwegian civil society (Ph.d.). Bergen: University of Bergen.

Enjolras, B., Karlsen, R., Steen-Johnsen, K., \& Wollebæk, D. (2013). Liker - liker ikke. Sosiale medier, samfunnsengasjement og offentlighet. Oslo: Cappelen Damm Akademisk.

Enjolras, B., Steen-Johnsen, K., \& Wollebæk, D. (2013). Social media and mobilization to offline demonstrations: Transcending participatory divides? New Media \& Society, 15(6): 890-908.

Folkestad, B., Christensen, D. A., Strømsnes, K., \& Selle, P. (2015). Frivillig innsats i Noreg 1998-2014. Kva kjenneteikner dei frivillige og kva har endra seg? Rapport 4/2015. Bergen/Oslo: Senter for forskning på sivilsamfunn og frivillig sektor.

Gil de Zúñiga, H., Puig-I-Abril, E., \& Rojas H. (2009). Weblogs, traditional sources online and political participation: an assessment of how the internet is changing the political environment. New Media \& Society, 11(4): 553-574.

Gil de Zúñiga, H., Bachmann, I., \& Hsu, S. H. (2013). Expressive versus consumptive blog use: implications for interpersonal discussion and political participation. International Journal of Communication, 7: 1538-1559. 
Gil de Zúñiga, H., Jung, N., \& Valenzuela, S. (2012) Social media use for news and individuals' social capital, civic engagement and political participation. Journal of Computer-Mediated Communication, 17(3): 319-336.

Gil de Zúñiga, H., Copeland, L., \& Bimber, B. (2014). Political consumerism: Civic engagement and the social media connection. New Media \& Society, 16(3): 488-506.

Gil de Zúñiga, H., Molyneux, L., \& Zheng, P. (2014). Social media, political expression and political participation: Panel analysis of lagged and concurrent relationships. Journal of Communication ,64(4): 612-634.

Guo, C., \& Saxton, G. (2014). Tweeting social change: How social media are changing nonprofit advocacy. Nonprofit and voluntary sector quarterly. 43(1): 57-79.

Hendriks, P. G. J., Hagemann, C. P. M., \& Van Snippenburg, L. B. (2004). Political knowledge and media use in the Netherlands. European Sociological Review, 20: 415-424.

Inglehart, R. (1997) Modernization and postmodernization: Cultural, economic and political change in 43 societies, Princeton: Princeton University Press.

Kanter, B., \& Fine, A.H. (2010). The networked nonprofit: Connecting with social media to drive change. Jossey-Bass.

Krueger, B. S. (2002). Assessing the potential of Internet political participation in the United States: A resource approach. American Politics Research, 30: 476-498.

Kushin, M. J., \& Yamamoto, M. (2010). Did social media really matter? College students' use of online media and political decision making in the 2008 election. Mass Communication and Society, 13(5): 608-630

Lovejoy, K., \& Saxton, G. D. (2012). Information, community, and action: How nonprofit orga- nizations use social media. Journal of Computer-Mediated Communication, 17: 337-353.

Margolis, M., \& Resnick, D. (200o). Politics as Usual: The Cyberspace "Revolution." Thousand Oaks, CA: Sage.

Morozov, E. (2009). The brave new world of slacktivism. I S. Glasser (Red.) Foreignpolicy.com. Washington: Slate Group.

Norris, P. (1999). Critical citizens. Global support for democratic governance, Oxford: Oxford University Press.

Norris P. (2001). Digital Divide: Civic Engagement, Information Poverty, and the Internet Worldwide. Cambridge: Cambridge University Press.

Polat, R. K. (2005). The Internet and political participation: Exploring the explanatory links. European Journal of Communication, 20: 435-459.

Park, N, Kee, K. F., \& Valenzuela, S. (2009). Being immersed in social networking environment: Facebook groups, uses and gratifications, and social outcomes. Cyberpsychology, Behavior and Social Networking, 12(6): 729-733. 
Putnam, R. D. (2000). Bowling Alone. The Collapse and Revival of American Democracy. New York: Simon \& Schuster.

Skocpol, T, \& Fiorina, M. P. (1999). Civic engagement in American democracy. Brookings Institution Press.

Skoric, M. M., \& Kwan, G. C. E. (2011). Platforms for mediated sociability and online social capital: The role of Facebook and massively multiplayer online games. Asian Journal of Communication, 21(5): 467-484.

Skoric, M. M., \& Poor, N. D. (2013). Youth engagement in Singapore: The interplay of traditional and social media. Journal of Broadcasting and Electronic Media, 57(2): $1-18$.

Vitak, J., Zube, P., \& Smock, A. (2011). It's complicated: Facebook users' political participation in the 2008 election. Cyberpsychology, Behavior and Social Networking, 14(3): 107-114.

SSB. (2018). Bruk av IKT i husholdningene. https://www.ssb.no/ikthus

Stein, L. (2009). Social movement web use in theory and practice: a content analysis of US movement websites. New Media \& Society, 11(5): 749-771.

Valenzuela S., Park, N., \& Kee, K. F. (2009). Is there social capital in a social network site? Facebook use and college students' life satisfaction, trust, and participation. Journal of Computer Mediated Communication, 14(4): 875-901.

Verba, S., Schlozman, K. L., \& Brady, H. E. (1995). Voice and Equality: Civic Voluntarism in American Politics. Cambridge, MA: Harvard University Press.

Vitak, J. (2012). The impact of context collapse and privacy on social network site disclosures. Journal of Broadcasting \& Electronic Media 56(4): 451-470.

Weber, L. M., Loumakis, A., \& Bergman, J. (2003). Who participates and why? An analysis of citizens on the Internet and the mass public. Social Science Computer Review, 21: 26-42.

Wellman, B., Quan-Haase, A., Witte, J., \& Hampton, K. (2001). Does the Internet increase, decrease or supplement social capital? Social networks, participation and community commitment. American Behavioral Scientist, 45: 436.

Wright, S. (2010). Political as usual? Revolution, normalization and a new agenda for online deliberation. I F. De Cindio, A. Machintosh, \& C. Peaboni (Reds.) Online Deliberation. Fourth International Conference, OD2010. Leeds.

Zhang, W., Johnson, T. J., \& Seltzer, T. (2010). The revolution will be networked: The influence of social networking sites on political attitudes and behavior. Social Science Computer Review, 28(1): 75-92.

Zukin, C., Keeter, S., Andolina, M., Jenkins, K., \& Delli Carpini, M. (2006). A new engagement? Political participation, civic life and the changing American citizen. New York: Oxford University Press. 


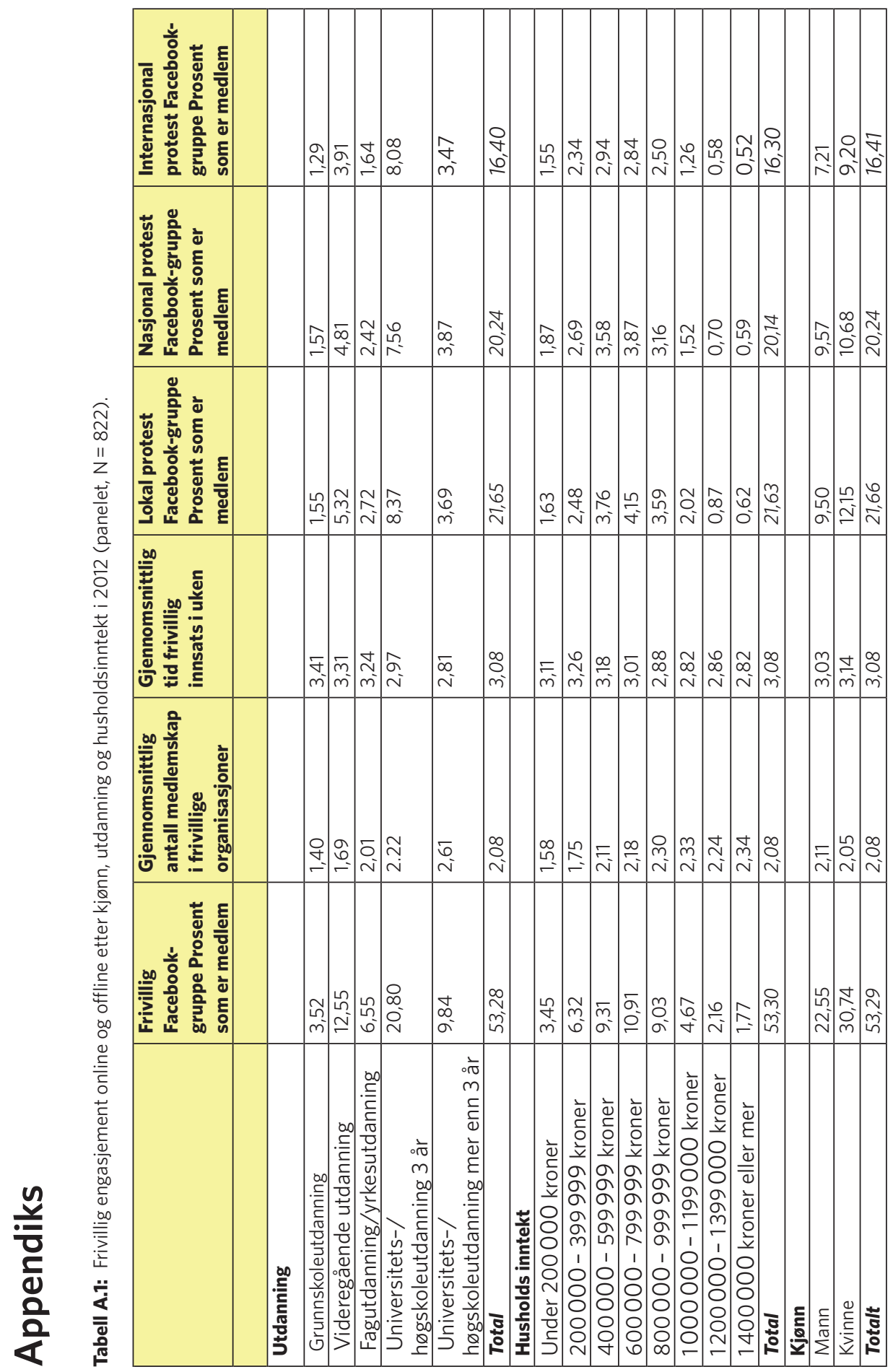




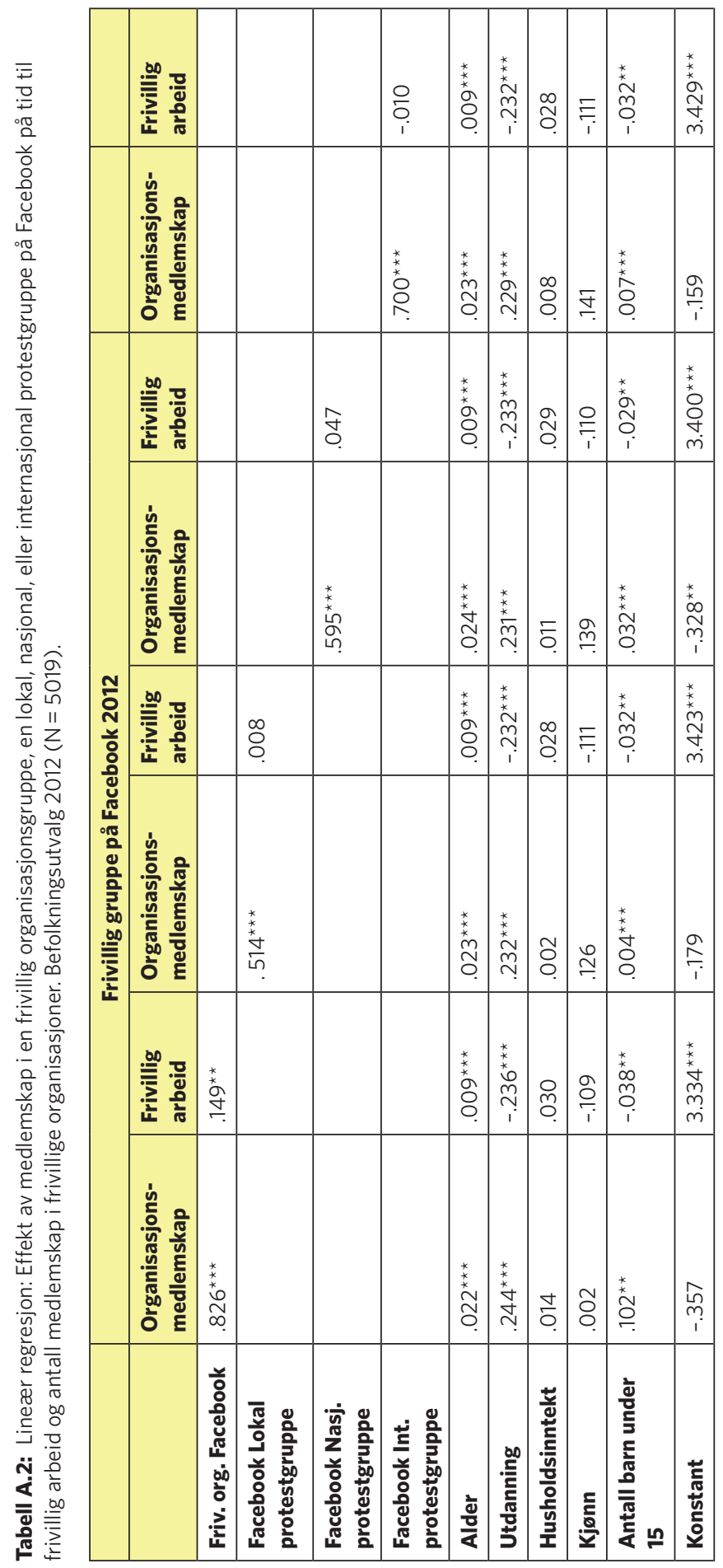




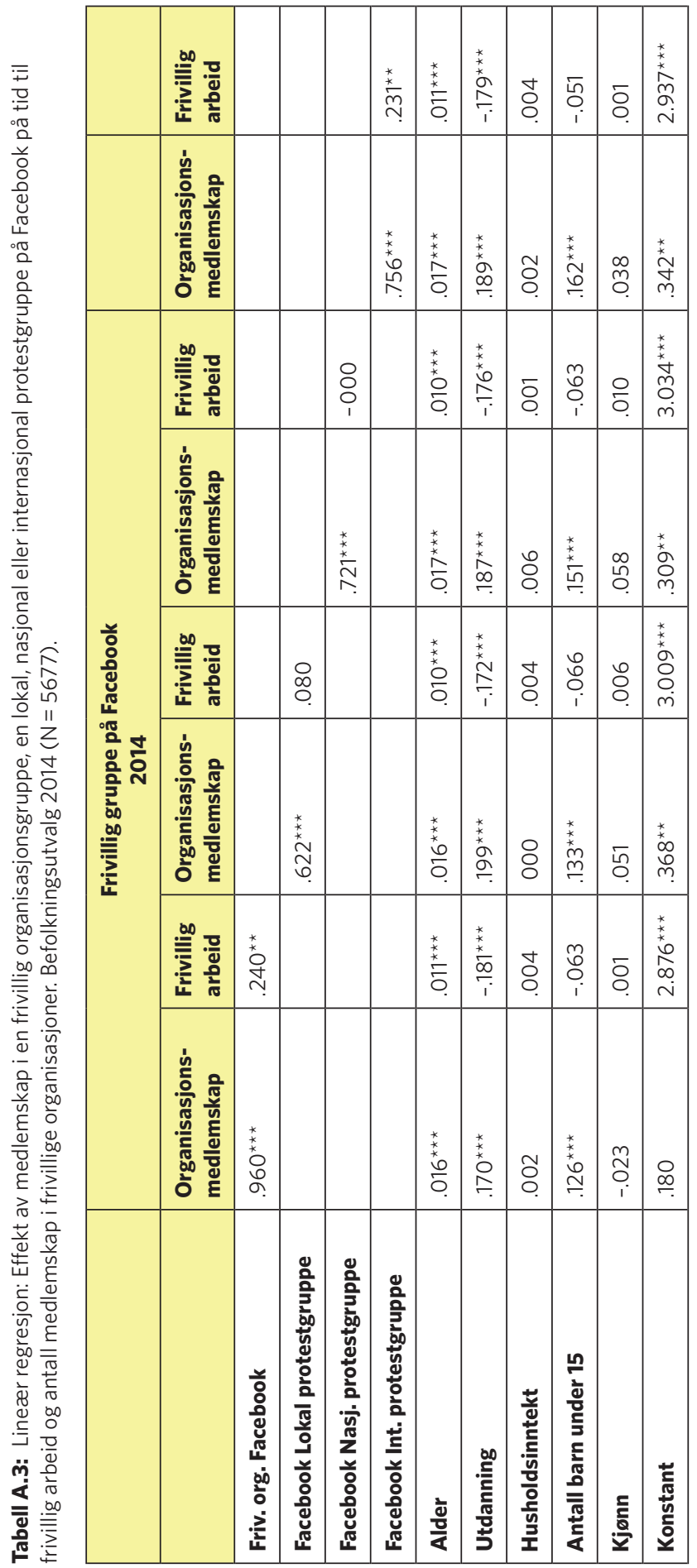




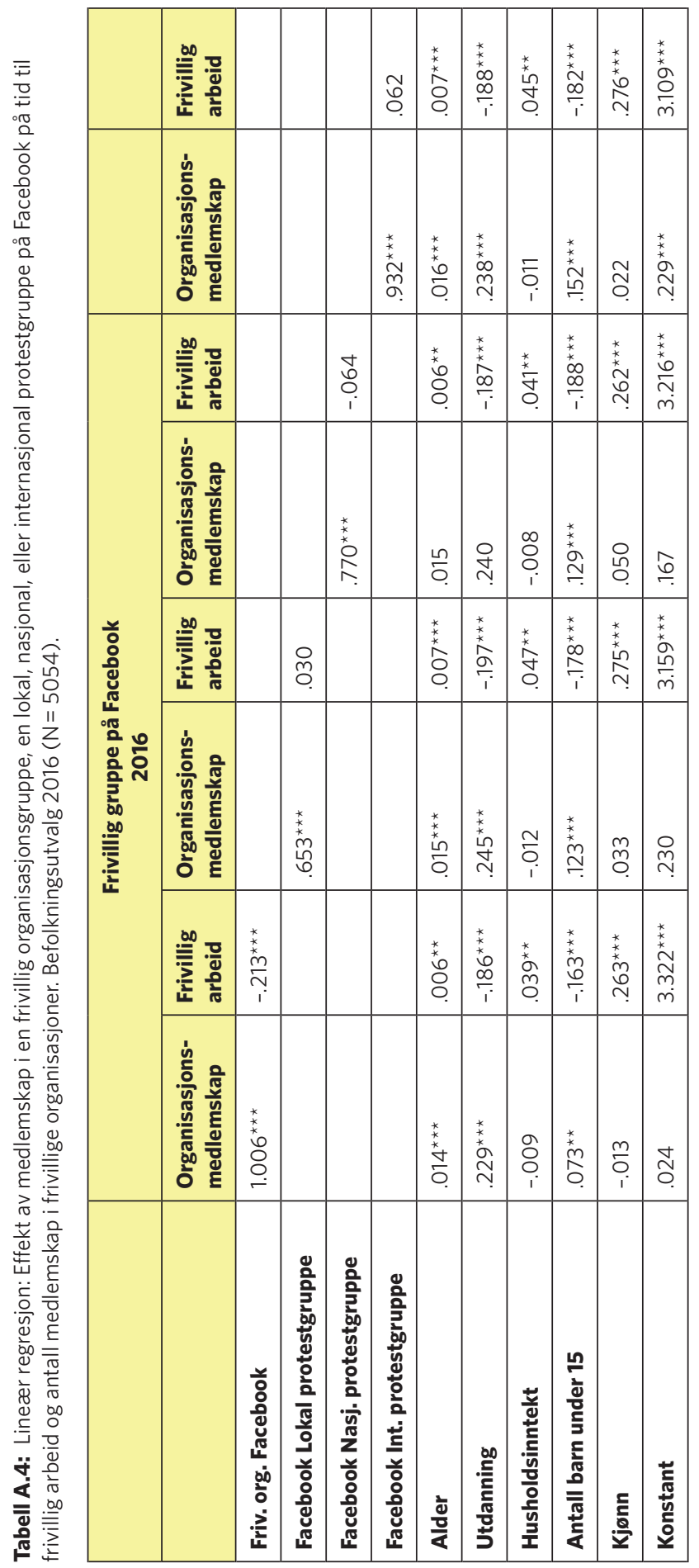




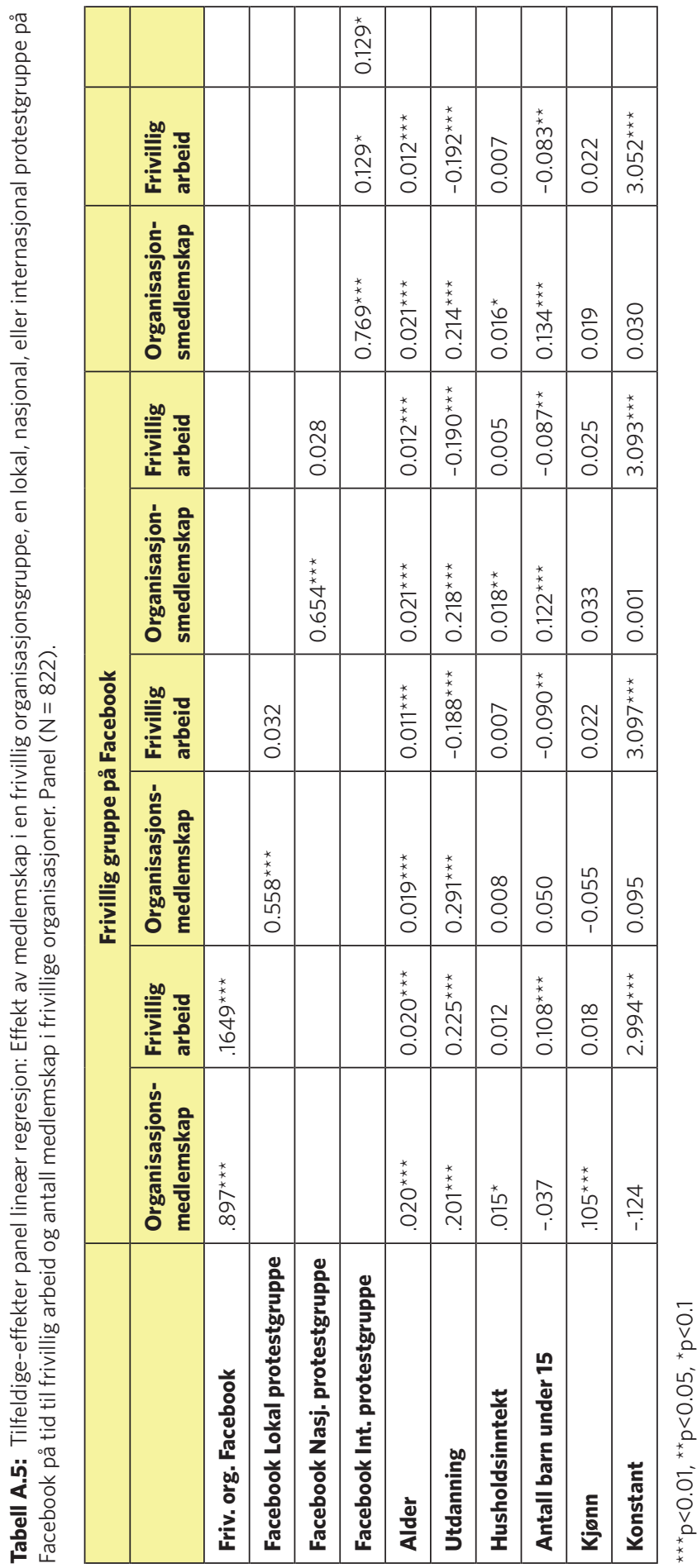




\title{
Tradisjonelle organisasjoner og nye frivillige initiativ $i$ flyktningsituasjonen høsten 2015. Mobilisering eller forsterkning av eksisterende skiller?
}

\author{
Audun Fladmoe \\ Institutt for samfunnsforskning
}

\begin{abstract}
This chapter studies voluntary contributions in Norway during the refugee crisis in 2015. Due to increased asylum arrivals, the public reception centers were overloaded and there was an urgent need for assistance from civil society actors. In addition to contributions from traditional voluntary organizations, a number of new voluntary initiatives were established. This makes the migration crisis a unique case for studying new forms of engagement: Did the migration crisis mobilize new groups of volunteers, or did the situation rather reinforce existing cleavages between volunteers and nonvolunteers? Based on survey panel data carried out before (2014) and after (2016) the migration crisis we analyze cleavages between volunteers and non-volunteers related to variations in sociodemographic background and political party preferences. The results show indications of both mobilization and reinforcement of existing cleavages, but in the long run existing cleavages seems to be preserved. Compared to the traditional organizations, new voluntary initiatives recruited more contributions from the young, low educated and low-income groups, but the number of 'new' volunteers was limited the majority of those who contributed had previous experience as organizational volunteers. Furthermore, we find few indications that involvement during the migration crisis contributed to increased participation in traditional voluntary work a year later. Thus, the results suggest that, in the context of the migration crisis, we observed a short-term mobilization of some new groups, but in the longer run, the voluntary sector is characterized by established cleavages between volunteers and non-volunteers.
\end{abstract}

Keywords: refugee crisis, voluntary contributions, political engagement, traditional organizations, new voluntary initiatives, social inequality

Sitering av denne artikkelen: Fladmoe, A. (2018). Tradisjonelle organisasjoner og nye frivillige initiativ i flyktningsituasjonen høsten 2015. Mobilisering eller forsterkning av eksisterende skiller? B. Enjolras \& I. Eimhjellen (Red.), Fra kollektiv til konnektiv handling? Nye former for samfunnsengasjement og kollektiv handling i Norge (s. 127-150). Oslo: Cappelen Damm Akademisk. https://doi.org/10.23865/noasp.45.ch5

Lisens: CC BY-NC 4.0 


\section{Innledning}

I 2015 kom det flere enn 1,3 millioner asylsøkere og flyktninger til Europa. Situasjonen ble omtalt som en europeisk flyktningkrise (Greussing \& Boomgaarden, 2017). Også Norge ble sterkt berørt. Drøyt 31 ooo mennesker søkte om beskyttelse her i landet, noe som var en tredobling fra året før. Situasjonen i Norge ble opplevd som akutt fordi søkerne kom i løpet av noen intense høstmåneder, og fordi få hadde forutsett omfanget og hastigheten på asylankomstene. I den tidlige fasen ble alle som kom, sendt til registrering hos Politiets utlendingsenhet (PU) på Tøyen i Oslo. Dette førte til overbelastning på registreringskontoret, og det hopet seg opp med mennesker i og rundt lokalene. Mediene rapporterte om kritikkverdige forhold, blant annet om folk som sov på gulvet på venterommet, uten tilgang til sanitære fasiliteter eller et skikkelig måltid. ${ }^{1}$

Det ble raskt klart at det offentlige mottaksapparatet ikke strakk til, og at det var stort behov for bidrag fra sivilsamfunnet. Sivilsamfunnets mobilisering foregikk både gjennom etablerte organisasjonskanaler og gjennom nyetablerte nettverk. Etablerte aktører som Røde Kors, Norsk Folkehjelp og Redd Barna var viktige støttespillere for myndighetene i akuttfasen og på mottakene. I tillegg til tradisjonelle frivillige organisasjoner var vi også vitne til at privatpersoner og nyopprettede initiativer, som Refugees Welcome og Dråpen i havet, mobiliserte frivillige blant annet ved aktiv bruk av sosiale medier (Eimhjellen, kommende). Både etablerte og nyopprettede frivillige initiativer var sentrale i akuttfasen, med overnatting, klær og helsehjelp, og etter hvert med aktiviteter og tilbud på mottak.

Med sin tydelig tidsavgrensede karakter og med fremveksten av nye frivillige initiativ er flyktningsituasjonen i 2015 en velegnet case for å studere nye kollektive handlingsformer. Digitale hjelpemidler, med utstrakt bruk av sosiale medier, var sentrale i spredningen og organiseringen av engasjementet. Flyktningsituasjonen var global; nye nettverk oppstod på tvers av landegrenser, og frivillige reiste til andre land i Europa for å bidra. Og grensene mellom politisk og frivillig engasjement fløt tilsynelatende

1 Se for eksempel: https://www.dagsavisen.no/innenriks/8o-sover-rett-pa-gulvet-1.378589 
over i hverandre (se Sandri, 2018, for en lignende beskrivelse av frivilliges rolle i «jungelen» i Calais, Frankrike).

I dette kapitlet ser vi nærmere på mobiliseringen av det frivillige engasjementet i Norge under flyktningsituasjonen. Mange studier har vist at deltakelse i frivillig arbeid er preget av sosiale skiller knyttet til faktorer som utdanning, inntekt og nettverk. Et hovedspørsmål i kapitlet er om mobiliseringen i forbindelse med flyktningsituasjonen høsten 2015 bidro til at nye grupper ble rekruttert til frivillig organisasjonsarbeid, og om dette førte til økt frivillig engasjement på lengre sikt. Dette studerer vi langs to spor. For det første kan oppblomstringen av nye frivillige initiativ med utstrakt bruk av sosiale medier redusere terskelen for å bidra frivillig. Dette åpner for at personer som normalt ikke rekrutteres inn i organisasjonsfrivilligheten, finner arenaer for deltakelse. Bidro den akutte situasjonen og de mange nye frivillige initiativene til å rekruttere bredere lag av befolkningen til frivillig engasjement? For det andre var det i mange tilfeller uklart om engasjementet overfor flyktninger kunne beskrives som «frivillig arbeid» eller "politisk aktivisme». Graden av «politisering» av engasjementet har betydning for hvor bred mobiliseringen i realiteten var. Vi spør derfor også om flyktningsituasjonen mobiliserte tverrpolitisk, eller om personer med bestemte politiske sympatier var overrepresentert blant de frivillige.

Analysene i kapitlet bygger på data fra Norsk medborgerpanel, der enkeltindivider har blitt fulgt over tid. Datamaterialet inneholder således informasjon om individenes frivillige engasjement både før, under og etter flyktningsituasjonen. Dermed kan vi sammenligne deltakelse i tradisjonell organisasjonsfrivillighet høsten 2014 med frivillige bidrag i flyktningsituasjonen høsten 2015 og tradisjonell organisasjonsfrivillighet igjen høsten 2016.

\section{Flyktningsituasjonen og nye frivillige initiativ}

Flyktningsituasjonen fikk for alvor stor plass i norsk offentlighet sensommeren 2015 (se Eimhjellens kapittel 7 i denne boken). Flere steder i Europa oppstod det nye frivillige initiativ, utenfor rammene av etablerte institusjoner (Sandri, 2018; Simsa, Rameder, Aghamanoukjan \& Totter, 
2018). Disse oppstod dels fordi pågangen av frivillige var for stor til at de etablerte organisasjonene klarte å organisere et tilbud for alle som ville bidra, men også fordi etablerte organisasjoner flere steder glimret med sitt fravær. Et eksempel på det sistnevnte så vi i den såkalte jungelen utenfor Calais i Frankrike, der franske myndigheter nektet å bistå, og der det stort sett bare var Leger uten grenser som engasjerte seg. I vakuumet som oppstod, ble det etablert en rekke nye nettverk og uorganiserte grupper av frivillige fra flere europeiske land, som ønsket å bidra med ulike former for engasjement (Sandri, 2018). Ruth Simsa med kolleger omtaler denne typen engasjement som «spontan frivillighet»: «[...] a form of volunteering in which volunteers arrive at a scene of sudden needs, caused by a crisis, in an unplanned, spontaneous, and ad hoc mode» (Simsa mfl., 2018, ikke paginert).

Situasjonen var på langt nær like dramatisk i Norge som i Calais, men også her ble mange frivillige engasjert utenfor rammene av etablerte organisasjoner, både fordi pågangen av frivillige var stor, og fordi mange følte at de etablerte organisasjonene ikke handlet raskt nok (Sætrang, 2016). Mest oppmerksomhet fikk trolig «Refugees Welcome»-nettverket, som oppsto som lokale hjelpegrupper i flere land og byer i Europa. I Norge sprang denne ut av en lokal organisering blant en gruppe spontane frivillige som delte ut mat og utstyr til flyktninger som stod i kø ved registreringskontoret på Tøyen (mer om dette i kapittel 6). Innsamling av utstyr og organisering av arbeidet skjedde på Facebook, gjennom gruppen «Refugees Welcome to Norway». I løpet av kort tid hadde denne Facebook-gruppen over 80 ooo medlemmer (Sætrang, 2016).

De nye initiativene spredte seg også geografisk i raskt tempo, parallelt med en omfattende medieoppmerksomhet omkring flyktningsituasjonen i Norge og internasjonalt. Ivar Eimhjellen har kartlagt fremveksten av «hjelpegrupper» på Facebook, og fant at det ble opprettet minst 140 grupper i løpet av 2015. Rundt 90 av disse var tilknyttet Refugees Welcome-nettverket, mens om lag 25 var tilknyttet Dråpen i havet. Fremveksten var særlig stor i perioden fra 20. august og ut september, da det ble registrert 92 nye grupper rundt omkring i Norge (Eimhjellen, kommende; Fladmoe, Sætrang, Eimhjellen, Steen-Johnsen \& Enjolras, 2016). 


\section{Mobilisering eller forsterkning av eksisterende forskjeller?}

Flere studier har påvist tydelige sosiale skjevheter knyttet til deltakelse i tradisjonell organisasjonsfrivillighet: Personer med høy utdanning og inntekt, som er i arbeid og som har brede sosiale nettverk, er overrepresentert blant frivillige (Folkestad, Christensen, Strømsnes \& Selle, 2015; Wollebæk \& Sivesind, 2010). Den såkalte ressursteorien skiller mellom tre former for kapital, som alle hver for seg øker sannsynligheten for at folk deltar i frivillig arbeid (Musick \& Wilson, 2008). Humankapital viser til egenskaper som utdanning, arbeidsmarkedsdeltakelse, inntekt, osv. Personer som har mye humankapital, har gjerne evner som er relevante for mange former for frivillig arbeid, noe som gjør dem attraktive for frivillige organisasjoner. Sosial kapital viser i denne sammenheng til sosiale nettverk. Personer som inngår i sosiale nettverk der mange deltar i frivillig arbeid, har større sannsynlighet for selv å delta. Nyere norske studier har vist at forespørsler - det å bli spurt av noen - er den suverent viktigste årsaken til at man blir rekruttert til frivillig arbeid (Wollebæk, Sætrang \& Fladmoe, 2015). Til sist viser kulturell kapital til verdier og holdninger som øker sannsynligheten for frivillig deltakelse.

Spørsmålet vi stiller i dette kapitlet, er om den frivillige mobiliseringen i forbindelse med flyktningsituasjonen høsten 2015 bidro til mobilisering av bredere lag av befolkningen, og om denne mobiliseringen bidro til økt frivillig organisasjonsdeltakelse på lengre sikt. Med en oppblomstring av nye frivillige initiativ og utstrakt bruk av digitale verktøy kan terskelen for å bidra frivillig senkes. Dette åpner for at personer som normalt ikke rekrutteres inn i organisasjonsfrivilligheten, finner egnede arenaer for deltakelse. Et eksempel er Facebook-sidene til Refugees Welcome, som fungerte som et lavterskeltilbud der enkeltpersoner tilbød seg å bidra med for eksempel klær og utstyr. Dette genererte igjen frivillig arbeidsinnsats fra andre i form av innsamling og utdeling (Sætrang, 2016).

Som beskrevet i bokens innledende kapittel, er det i faglitteraturen en debatt om digitalisering, og spesielt utbredelsen av sosiale medier, bidrar til en demokratisering av samfunnsengasjement (Norris, 2001). To 
overordnede hypoteser står mot hverandre: «mobiliseringshypotesen» og «forsterkningshypotesen». Ifølge mobiliseringshypotesen vil grupper som ikke tidligere har vært aktive, lettere bli engasjert når informasjon blir gjort mer allment tilgjengelig, og når mulighetsrommet for engasjement $ø$ ker. Ved at det er mulig å nå bredere ut, reduseres barrierer knyttet til human-, sosial og kulturell kapital. For eksempel vil informasjon som spres i sosiale medier, gjerne nå langt utover etablerte nettverk av frivillige, og på den måten kan betydningen av ens personlige sosiale nettverk bli mindre. Mulighetsrommet for engasjement utvides også gjerne under dramatiske hendelser, fordi den tradisjonelle organisasjonsinnsatsen ikke er tilstrekkelig og det oppstår et behov for supplement fra mer spontane former for frivillighet (Simsa mfl., 2018).

Motsatt sier forsterkningshypotesen at det først og fremst er de som allerede er aktive, som utnytter mulighetene som ligger i digitale medier. Digitalisering og nye kollektive handlingsformer kan bidra til å reprodusere, eventuelt forsterke, eksisterende ulikheter blant frivillige, fordi det først og fremst er de som allerede er engasjert, som har erfaring med og som får kjennskap til nye muligheter for deltakelse. Selv om digitalisering fører til at informasjon spres raskere og bredere, er kunnskapen om ulike muligheter for deltakelse høyere blant personer som har erfaring, og som inngår i nettverk av etablerte frivillige.

Gjentatte studier av etablert organisasjonsfrivillighet, både i Norge og internasjonalt, har vist hvordan ressursteorien holder seg over tid - altså at det er en overrepresentasjon av ressurssterke blant dem som utfører frivillig arbeid (Folkestad mfl., 2015; Musick \& Wilson, 2008). I rekrutteringen til frivillig arbeid har det også vist seg at sosiale nettverk er svært viktig. Når personer som inngår i de samme nettverkene rekrutteres, bidrar det til at eksisterende forskjeller opprettholdes (Wollebæk mfl., 2015). Vi har begrenset med empirisk kunnskap fra Norge om potensialet for bredere og mer spontan mobilisering når det oppstår dramatiske hendelser. Internasjonalt har studier av frivillige bidrag i forbindelse med naturkatastrofer vist at mange spontane frivillige ikke har tidligere tilknytning til etablerte organisasjoner (Drabek \& McEntire, 2003). I Norge har studier av digitalt frivillig arbeid vist at denne form for innsats tiltrekker seg flere yngre enn hva tradisjonelt frivillig arbeid gjør, noe som 
kan indikere at denne typen aktiviteter mobiliserer i grupper som tradisjonelt er mindre aktive i frivillig arbeid. Samtidig har det vist seg at også blant digitale frivillige er det en overvekt av høyt utdannede, noe som peker mot en reproduksjon av kjennetegn ved eksisterende grupper av frivillige (Eimhjellen \& Ljunggren, 2017).

Den direkte betydningen av digitale medier på samfunnsengasjement behandles i kapittel 4 i denne boken. I dette kapitlet ser vi nærmere på to måter frivillige bidrag i flyktningsituasjonen ble organisert på, henholdsvis gjennom tradisjonelle frivillige organisasjoner og gjennom nye frivillige initiativ. Ifølge mobiliseringshypotesen kan vi anta at de nye initiativene, som la til rette for spontan frivillighet, i større grad enn tradisjonelle organisasjoner tiltrakk seg flere nye frivillige (personer som ikke tidligere hadde deltatt i frivillig arbeid), og at den sosiale sammensetningen var annerledes enn hva vi tradisjonelt observerer i studier av frivillig engasjement. Dersom denne gruppen frivillige opprettholdt sitt frivillige engasjement også etter flyktningsituasjonen høsten 2015, kan dette dermed ha ført til endringer i sammensetningen av frivillige i Norge. Motsatt kan vi i henhold til forsterkningshypotesen forvente at de som engasjerte seg i nye frivillig initiativ, har mer eller mindre de samme kjennetegnene som de som engasjerte seg i etablerte organisasjoner, og dermed kan vi heller ikke forvente at flyktningsituasjonen bidro til å endre sammensetningen av frivillige.

\section{Hvor bred var mobiliseringen? Flyktningsituasjonens politiske dimensjon}

Mens ressursteorien først og fremst er opptatt av den sosiale sammensetningen blant frivillige, basert på faktorer som inntekt, utdanning og nettverk, er det også andre relevante egenskaper som sier noe om bredden i mobiliseringen av frivillige. I studier av frivillig engasjement knyttet til samfunnsaktuelle spørsmål er det særlig relevant å undersøke i hvilken grad det mobiliseres frivillige med et mangfold av politiske meninger, eller om mobiliseringen først og fremst skjer blant grupper med bestemte politiske oppfatninger. Tidligere studier av spontan frivillighet har ofte vært knyttet til naturkatastrofer, som er apolitiske hendelser der «alle» 
er enige om målet (Simsa mfl., 2018). Flyktningspørsmål, sammen med andre relaterte spørsmål knyttet til migrasjon, er på sin side blant de mer politiserte spørsmålene i vår tid. Flere av de politiske partiene har en tydelig profil i disse sakene, og stortingsvalgundersøkelsene har over lengre tid vist at synet på innvandrere og innvandring polariserer velgerne (se f.eks. Aardal, 2003, 2015). Spørsmålet som reises, er derfor om denne polariseringen også var synlig blant de som engasjerte seg i flyktningsituasjonen, og i så fall om mobiliseringen først og fremst skjedde blant personer med bestemte politiske oppfatninger.

Den frivillige sektoren i Norge hadde opprinnelig sterke politiske trekk. De store folkebevegelsene i Norge sprang ut av politiske konfliktlinjer knyttet til forhold som sosial klasse, religion, språk, avhold, geografi, som manifesterte seg både i sivilsamfunnsorganisasjoner og politiske partier - som gjerne selv hadde sterke interne bindinger (f.eks. arbeiderbevegelsen med bl.a. Arbeiderpartiet, LO og Norsk Folkehjelp) (jf. Rokkan, Hagtvet \& Alldén, 1987, kap. 6). Frivillig innsats var noe som fulgte naturlig av tilhørighet til et organisert kollektiv, og selve begrepet «frivillig innsats» har også en relativt kort historie i Norge. Man snakket snarere om «aktivt organisasjonsmedlemskap», som både kunne handle om politisk aktivisme og det vi i dag kaller frivillig innsats (Wollebæk \& Selle, 2008). Med svekkede folkebevegelser og økt individualisme har frivilligheten i økende grad fremstått som apolitisk, og i forskningslitteraturen opereres det ofte med et skille mellom frivillig innsats og politisk aktivisme (Eliasoph, 2013). I henhold til dette skillet forstås frivillig innsats som det å løse samfunnsproblemer gjennom kollektive handlinger, mens politisk aktivisme i større grad søker å oppnå samfunnsendringer.

Engasjementet vi så i flyktningsituasjonen, reiser spørsmålet om det i dette tilfellet gir mening å skille så skarpt mellom frivillig innsats og politisk aktivisme. Det er rimelig å anta at syn på flyktningpolitikk og migrasjonsspørsmål mer generelt har betydning for om man bidro frivillig under flyktningsituasjonen. Motivasjonen for å bidra kan ha vært å løse akutte samfunnsproblemer, men også å påvirke opinionen og politikken på feltet. På den måten utviskes skillet mellom frivillig innsats og politisk aktivisme. Elisa Sandri (2018) bruker begrepet «frivillig 
humanitærisme» (volunteer humanitarianism) om ikke-profesjonelle frivillige bidrag overfor flyktninger i Calais i Frankrike i denne perioden. I utgangspunktet engasjerte mange seg fordi de ønsket å hjelpe (frivillig innsats), men etter hvert fløt dette mer eller mindre ubevisst over i politisk aktivisme. For mange av dem som engasjerte seg, ble skillene mellom de ulike formene for samfunnsengasjement utvisket.

Samtidig er det heller ikke riktig å omtale engasjementet under flyktningsituasjonen som «aktivt organisasjonsmedlemskap». Når frivillige engasjerer seg i nye frivillige initiativ og andre uorganiserte grupper, er det begrenset hvor viktig tilhørigheten til et organisert kollektiv er. Snarere er det saken som står i sentrum, og engasjementet drives av den individuelle motivasjonen for å bidra. Dette kan knyttes til det som omtales som mer ekspressive former for frivillighet, der saken og den individuelle motivasjonen er viktigere enn den kollektive identiteten og rammene innsatsen foregår innenfor (Hustinx \& Lammertyn, 2003). Utviklingen fra kollektiv til mer refleksiv og individualisert frivillighet har blitt dokumentert i flere norske studier (Wollebæk \& Selle, 2008; Wollebæk mfl., 2015). Et konkret eksempel på denne utviklingen er hvordan stadig færre frivillige uttrykker sterk organisasjonstilhørighet (stadig flere oppgir at de like gjerne kunne gjort innsatsen for en annen organisasjon), det er flere frivillige som ikke er medlem av de organisasjonene de gjør en innsats for, og de frivillige uttrykker økt indre motivasjon for frivillig deltakelse (Wollebæk mfl., 2015). Analytisk har en eventuell utvisking av skillet mellom frivillig innsats og politisk aktivisme konsekvenser for hvordan mobiliserings- og forsterkningshypotesen kan tolkes. Dersom frivillige bidrag i flyktningsituasjonen først og fremst ble mobilisert blant personer med bestemte politiske preferanser, kan det argumenteres for at begge hypotesene må modifiseres i dette konkrete tilfellet. Selv om nye grupper som tradisjonelt er underrepresentert i frivilligheten kommer til (mobilisering) eller eksisterende grupper utvider sitt engasjement (forsterkning), svekkes støtten til begge hypotesene dersom enkeltgrupper er overrepresentert på bakgrunn av politisk ståsted. Vårt argument er med andre ord at disse hypotesene også må ta inn over seg andre faktorer enn sosial bakgrunn. Dersom det for eksempel mobiliseres sterkere blant lavt utdannede personer enn det som er vanlig, kan det diskuteres hvor bred 
mobiliseringen er dersom disse i overveiende grad har sammenfallende politiske preferanser med høyt utdannede frivillige.

Den empiriske strategien i kapitlet er med andre ord å undersøke betydningen av både tidligere erfaring som frivillig, sosial bakgrunn og politiske preferanser blant dem som bidro i flyktningsituasjonen i 2015, henholdsvis for etablerte organisasjoner og nye frivillige initiativ. Videre vil vi undersøke i hvilken grad de som bidro i flyktningsituasjonen, fortsatt deltok i frivillig arbeid på et senere tidspunkt. På denne måten kan vi undersøke mobiliserings- og forsterkningshypotesen, både basert på sosial bakgrunn og politiske preferanser. Analysene muliggjøres av at vi har paneldata der de samme personene følges over tid. Dette beskriver vi grundigere i neste avsnitt.

\section{Data og metode}

Analysene i kapitlet bygger på data fra Norsk medborgerpanel, som er en spørreundersøkelse som gjennomføres to ganger i året blant et representativt utvalg av den norske befolkningen (for nærmere informasjon om panelet, se https://www.uib.no/medborger). Fordelen med panelet er at mange av respondentene deltar hver gang, noe som gjør det mulig å studere endringer i folks engasjement. I analysene i dette kapitlet utnytter vi dette ved å analysere spørsmål som de samme respondentene har besvart ved tre tidspunkt: først om tradisjonell organisasjonsfrivillighet høsten 2014, deretter om frivillige bidrag under flyktningsituasjonen i 2015/16 og til sist om tradisjonell organisasjonsfrivillighet høsten 2016. På denne måten har vi data om frivillig engasjement før, under og etter flyktningsituasjonen.

Til sammen 691 respondenter besvarte spørsmål om bidrag under flyktningsituasjonen 2015 samt spørsmål om organisasjonsfrivillighet i 2014 og 2016. I det endelige utvalget er det en overrepresentasjon av menn, eldre og personer med høyere utdanning (se tabell 1). I deskriptive analyser vekter vi for disse tre egenskapene, mens vi kontrollerer for dem i de multivariate analysene.

Vi benytter to sett med avhengige variabler: 1) frivillige bidrag under flyktningsituasjonen og 2) frivillig arbeid for organisasjoner ett år etterpå. 
Når det gjelder bidrag under flyktningsituasjonen, skiller vi mellom bidrag gitt i regi av henholdsvis (a) tradisjonelle organisasjoner og (b) nye initiativ. «Nye initiativ» inkluderer personer som svarte at de hadde bidratt i regi av «Et nylig opprettet initiativ/organisasjon» eller «Organiserte arbeidet på egen hånd/sammen med kjente». ${ }^{2}$ "Bidrag» viser $\mathrm{i}$ denne sammenhengen både til donasjoner (penger, mat, klær o.l.) og frivillig arbeidsinnsats. Til sammen 33 prosent av respondentene i utvalget svarte at de hadde bidratt med minst én aktivitet (uavhengig av hvordan bidraget ble organisert). 30 prosent svarte at de hadde gitt donasjoner, mens nærmere 7 prosent svarte at de (i tillegg) hadde bidratt med frivillig arbeidsinnsats. ${ }^{3}$

Når det gjelder frivillig arbeid for organisasjoner høsten 2016, måler denne variabelen hvorvidt respondentene i løpet av de siste 12 månedene har utført frivillig arbeidsinnsats for minst én organisasjon. I undersøkelsen ble det skilt mellom 15 organisasjonstyper, i tillegg til «annet». Spørsmålsformuleringen er lik som i de nasjonale Frivillig innsatsundersøkelsene (se Arnesen, 2015). ${ }^{4}$

Det er tre sett av uavhengige variabler som inkluderes i analysene. For det første, deltakelse i frivillig arbeid i 2014, altså i god tid før de $ø$ kte asylankomstene til Norge i 2015. I analysene av frivillig arbeid i 2016 kontrollerer vi også for frivillige bidrag under flyktningsituasjonen, som beskrevet over. For det andre ser vi på betydningen av ulike sosiodemografiske variabler, som kjønn, alder, utdanning og inntekt. Utdanningsvariabelen har fire verdier: 1 = ungdomsskole/folkeskole, 2 = Vgs/fagskole,

2 Den konkrete spørsmålsformuleringen var: «I løpet av det siste året har det kommet mange flyktninger og asylsøkere til Norge. Har du i løpet av de siste 12 månedene bidratt med noe av det følgende i forbindelse med flyktningsituasjonen? 1) Donasjoner, 2) Fysisk innsats, 3) Administrativ innsats, 4) Annen innsats». Hvis minst én innsats: «I regi av hvem har du utført frivillig innsats i forbindelse med flyktningsituasjonen? (flere svar mulig)». Svarlisten inkluderte også bidrag i regi av «Et asylmottak», «En privat virksomhet», «En offentlig virksomhet» og "Annet». Disse kategoriene er ikke inkludert i de videre analysene.

3 Merk at disse tallene skiller seg noe fra tallene som ble presentert i rapporten «Nordmenns bidrag i flyktningsituasjonen 2015/16» (Fladmoe mfl., 2016). Dette skyldes at vi her har utelatt respondenter som ikke besvarte undersøkelsen også høsten 2014 og høsten 2016.

4 Spørsmålsformuleringen var: «Har du i løpet av de siste 12 måneder utført frivillig, ulønnet arbeidsinnsats for frivillige organisasjoner på noen av følgende områder:» Deretter ble det listet opp 15 organisasjonskategorier (f.eks. idrett og sport, sosiale tjenester og rusomsorg, religion og livssyn) i tillegg til «Annet, spesifiser». 
3 = høgskole/universitet inntil bachelor/cand.mag., $4=$ høgskole/universitet, master/hovedfag eller mer, mens inntektsvariabelen (personlig bruttoinntekt) er delt inn i omtrent fem like store grupper (kvintiler): $1=$ inntil 300 ooo, $2=300001-400000,3=400001-500000,4=500001-$ 600 ooo, $5=600$ ooo eller mer. For det tredje ser vi på betydningen av partipolitiske preferanser. På grunn av et begrenset antall respondenter, er de mindre partiene slått sammen til to grupper: Rødt/SV/MDG og $\mathrm{Sp} / \mathrm{Krf} /$ Venstre. Resultatene endres ikke mye ved å studere hvert enkelt parti, men det lave antallet respondenter som har oppgitt at de stemmer på disse partiene fører til at den statistiske utsagnskraften blir svakere når de behandles hver for seg.

Deskriptiv statistikk for alle variablene er oppsummert i tabell 1. Tabellen viser at 23 prosent av respondentene bidro i regi av en tradisjonell organisasjon i flyktningsituasjonen, mens 7 prosent bidro i regi av et nytt initiativ. Om lag 65 prosent av respondentene svarte i 2014 og 2016 at de hadde deltatt i frivillig arbeid i regi av en frivillig organisasjon i løpet av de siste 12 månedene. Dette er noe høyere enn i den siste omfattende befolkningsundersøkelsen om deltakelse i frivillig arbeid, der nivået var 61 prosent. En sannsynlig forklaring på diskrepansen er at respondentene som deltar i Medborgerpanelet, i snitt er noe mer samfunnsengasjerte enn befolkningen generelt.

\section{Resultater}

Vi ser på resultatene i to deler. Først studerer vi frivillige bidrag under flyktningsituasjonen høsten 2015, dernest frivillig organisasjonsarbeid i 2016.

\section{Bidrag under flyktningsituasjonen høsten 2015}

Tabell 2 viser andelen som bidro i flyktningsituasjonen, etter bakgrunnskjennetegn. Tabellen viser for det første at blant dem som bidro, var det en klar overvekt av personer som også var organisasjonsfrivillige i 2014. Blant dem som var organisasjonsaktive høsten 2014, bidro 23 prosent i regi av en tradisjonell organisasjon under flyktningsituasjonen. Andelen 
Tabell 1: Deskriptiv statistikk i regresjonsanalysene

\begin{tabular}{|l|l|l|l|}
\hline & Gjennomsnitt & Min.-maks. & Observasjoner (n) \\
\hline Avhengige variabler & & & \\
\hline $\begin{array}{l}\text { Bidrag i regi av tradisjonell organisasjon i } \\
\text { flyktningsituasjonen 2015 }\end{array}$ & 0,23 & $0-1$ & 691 \\
\hline $\begin{array}{l}\text { Bidrag i regi av nytt initiativ i } \\
\text { flyktningsituasjonen 2015 }\end{array}$ & 0,07 & $0-1$ & 691 \\
\hline Frivillig organisasjonsarbeid 2016 & 0,64 & $0-1$ & 691 \\
\hline Uavhengige variabler & & & \\
\hline Frivillig organisasjonsarbeid 2014 & 0,66 & $0-1$ & 691 \\
\hline Kjønn (kvinner = 1) & 0,48 & $0-1$ & 691 \\
\hline Alder & & & 691 \\
\hline 18-35 år & 0,18 & $0-1$ & 691 \\
\hline 36-45 år & 0,14 & $0-1$ & 691 \\
\hline 46-55 år & 0,19 & $0-1$ & 691 \\
\hline 56-65 år & 0,23 & $0-1$ & 691 \\
\hline 66 år eller eldre & 0,26 & $0-1$ & 691 \\
\hline Utdanning & 2,71 & $1-4$ & 691 \\
\hline Inntekt & 2,88 & $1-5$ & 691 \\
\hline Partipreferanse & & $0-1$ & 691 \\
\hline $\begin{array}{l}\text { Rødt, Sosialistisk venstreparti (SV), } \\
\text { Miljøpartiet de grønne (MDG) }\end{array}$ & 0,11 & $0-1$ & 691 \\
\hline Arbeiderpartiet (Ap) & 0,29 & $0-1$ & 691 \\
\hline $\begin{array}{l}\text { Senterpartiet (Sp), Kristelig } \\
\text { folkeparti (Krf), Venstre }\end{array}$ & 0,16 & $0-1$ & 691 \\
\hline Høyre & 0,25 & $0-1$ & 691 \\
\hline Fremskrittspartiet (Frp) & 0,13 & 691 \\
\hline Andre partier / ikke stemt & 0,06 & $0-1$ & \\
\hline & & & \\
\hline
\end{tabular}

var 11 prosent blant dem som ikke var organisasjonsaktive høsten 2014. De tilsvarende tallene var 9,5 og 3,5 prosent blant dem som bidro i regi av et nytt initiativ. Denne tendensen var altså minst like sterk innenfor nye initiativ som innenfor tradisjonelle organisasjoner, noe som indikerer at nye frivillige initiativ ikke tiltrakk seg relativt sett flere nye frivillige enn det de tradisjonelle organisasjonene gjorde.

Selv om nye frivillige initiativ tiltrakk seg mange som hadde tidligere erfaring med frivillig organisasjonsarbeid, er den sosiodemografiske 
Tabell 2. Andel som bidro, etter kjennetegn. Prosent.

\begin{tabular}{|c|c|c|}
\hline & $\begin{array}{l}\text { Bidrag i regi av } \\
\text { tradisjonell organisasjon i } \\
\text { flyktningsituasjonen } 2015\end{array}$ & $\begin{array}{l}\text { Bidrag i regi av } \\
\text { nytt initiativ } i \\
\text { flyktningsituasjonen } \\
2015 \\
\end{array}$ \\
\hline Organisasjonsfrivillig 2014 & 23,2 & 9,5 \\
\hline Ikke organisasjonsfrivillig 2014 & 11,4 & 3,5 \\
\hline Sig. & 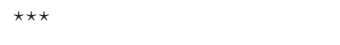 & ** \\
\hline Kvinner & 19,5 & 8,4 \\
\hline Menn & 18,6 & 6,5 \\
\hline \multicolumn{3}{|l|}{ Sig. } \\
\hline 18-35 år & 22,0 & 13,4 \\
\hline 36-45 år & 14,8 & 8,1 \\
\hline 46-55 år & 13,8 & 7,3 \\
\hline 56-65 år & 20,1 & 4,9 \\
\hline 66 år eller eldre & 21,1 & 1,0 \\
\hline Sig. & & 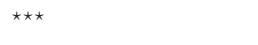 \\
\hline Grunnskole & 8,9 & 6,6 \\
\hline VGS & 18,9 & 6,7 \\
\hline Universitet/høgskole <4 år & 25,5 & 10,3 \\
\hline Universitet/høgskole $>4$ år & 26,5 & 7,2 \\
\hline Sig. & ** & \\
\hline$<300000$ & 18,1 & 8,8 \\
\hline $300.001-400000$ & 15,3 & 8,0 \\
\hline $400.001-500000$ & 20,4 & 6,3 \\
\hline $500.001-600000$ & 22,0 & 6,2 \\
\hline$>600000$ & 21,6 & 5,5 \\
\hline \multicolumn{3}{|l|}{ Sig. } \\
\hline Rødt, SV, MDG & 41,3 & 15,9 \\
\hline Arbeiderpartiet & 17,9 & 7,7 \\
\hline Sp, Krf, Venstre & 16,6 & 9,7 \\
\hline Høyre & 21,3 & 4,8 \\
\hline Frp & 6,4 & 0,0 \\
\hline Annet parti / ikke stemt & 10,7 & 10,2 \\
\hline Sig. & 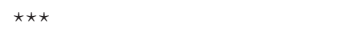 & *夫 \\
\hline
\end{tabular}

Kilde: Norsk medborgerpanel 2016.

Vektet etter kjønn, alder og utdanning.

Sig. nivå: ${ }^{\dagger} p<0,1,{ }^{\star} p<0,05,{ }^{\star \star} p<0,01,{ }^{\star \star \star} p<0,001$ 
profilen til dem som bidro for disse initiativene, annerledes enn blant dem som bidro for tradisjonelle organisasjoner. Mens aldersfordelingen er relativt jevn blant dem som bidro i regi av tradisjonelle organisasjoner, er det en tydelig skjevfordeling innenfor de nye initiativene, med en overvekt av personer mellom 18 og 45 år. Motsatt er utdanningsskjevheten mye tydeligere innenfor de tradisjonelle organisasjonene, med en klar overvekt av personer som har høyere utdanning. Innenfor nye initiativ er overvekten av høyt utdannede lavere, og variasjonen er ikke signifikant. Det er nærliggende å anta at dette delvis skyldes at unge var overrepresentert. Nettoeffekten av utdanning (kontrollert for alder) ser vi nærmere på i tabell 3. Uansett indikerer disse tallene at den sosiodemografiske profilen til dem som bidro innenfor nye initiativ, skiller seg fra tradisjonelle frivillige, da både unge og lavt utdannede er underrepresentert i tradisjonell frivillighet (Folkestad mfl., 2015). Disse funnene gir støtte til mobiliseringshypotesen innenfor nye frivillige initiativ og forsterkningshypotesen innenfor etablerte organisasjoner. Innenfor de nye initiativene var rekrutteringen annerledes enn det vi vanligvis ser i rekruttering til frivillig arbeid, noe som dermed i sum kan bidra til en bredere sosial profil på frivillige. Samtidig ser vi at etablerte sosiale skiller forsterkes, eller i det minste reproduseres, innenfor de tradisjonelle organisasjonene.

Bildet blir enda mer sammensatt når vi ser på de partipolitiske preferansene til dem som bidro. Bidrag i flyktningsituasjonen hadde en tydelig partipolitisk profil, og dette gjaldt i minst like stor grad blant dem som bidro for nye frivillige initiativ, som blant dem som bidro i regi av tradisjonelle organisasjoner. I begge grupper var det en klar overvekt av personer som svarte at de ville stemme på Rødt, SV eller MDG, mens det var en klar underrepresentasjon av personer som ville stemme på Frp. Blant de 90 personene i utvalget som svarte at de ville stemme Frp, er det ingen som svarte at de bidro i flyktningsituasjonen for et nytt initiativ. Det at det er en såpass tydelig partipolitisk polarisering på tvers av organiseringsformer, viser at bidrag i flyktningsituasjonen også kan forstås som en form for politisk deltakelse. Dette nyanserer både mobiliserings- og forsterkningshypotesen: Flyktningsituasjonen bidro til at enkelte sosiale grupper som vanligvis ikke deltar i frivillig arbeid, engasjerte seg, men engasjementet skjedde i hovedsak blant personer med relativt sammenfallende 
politiske holdninger. Når vi i tillegg ser at det var en overvekt av personer som tidligere hadde deltatt i frivillig arbeid (fra høsten 2014), kan det dermed stilles spørsmål ved i hvor stor grad flyktningsituasjonen bidro til en demokratisering av frivillighetsstokken. Ser vi på partiprofilen til organisasjonsfrivillige uavhengig av deltakelse i flyktningsituasjonen (se tabell 4), var den langt jevnere. Velgerne til Frp var også her noe underrepresentert - dog i langt mindre grad. Andelen frivillige var størst blant dem som stemte på et av sentrumspartiene (Sp, Krf eller Venstre).

For å vurdere den selvstendige effekten av hver variabel (nettoeffekten) er det viktig å se dem i sammenheng. Tabell 3 viser resultater fra logistiske regresjonsanalyser, der deltakelse i flyktningsituasjonen for de to organiseringsformene er avhengige variabler. Tabellen viser odds-sannsynlighet for å bidra frivillig når alle variabler kontrolleres for. Odds høyere enn «1» betyr positiv sammenheng, mens odds lavere enn «1» betyr negative sammenheng. Da utdanning og inntekt korrelerer, har vi estimert to modeller for hver bidragsform, der hver av disse variablene inkluderes.

Tabellen viser at noen av resultatene justeres når vi tar hensyn til andre forhold. Blant annet ser vi at det oppstår signifikante kjønns- og inntektsforskjeller blant dem som bidro for tradisjonelle organisasjoner (modell 2): Kvinner og personer med høy inntekt hadde større sannsynlighet for å bidra enn menn og personer med lav inntekt. Denne tendensen ser vi ikke blant dem som bidro for nye initiativ. Videre ser vi at aldersskjevheten blant dem som bidro for nye initiativ, er markant. Sammenlignet med den eldste aldersgruppen har de yngste og yngre middelaldrende (dem mellom 36 og 45) mye høyere sannsynlighet for å ha bidratt for nye initiativ.

Sett bort fra dette, ser vi fortsatt en tydelig sammenheng mellom organisasjonsfrivillighet i 2014 og bidrag i flyktningsituasjonen, tydelig utdanningsskjevhet blant dem som bidro for tradisjonelle organisasjoner i flyktningsituasjonen, og vi ser også en partipolitisk tendens. I tabellen er Arbeiderpartiets (Ap) velgere referansegruppen, og de andre partienes koeffisienter må tolkes som avvik fra disse. I alle modellene ser vi at det ikke er signifikante forskjeller mellom velgerne til Ap, Sp, Krf, Venstre og Høyre. Velgerne til Rødt, SV og MDG på den ene siden og Frp på den andre skiller seg imidlertid tydelig ut, med henholdsvis større eller mindre sannsynlighet for å bidra. 
Tabell 3. Kjennetegn ved frivillig engasjement. Odds fra logistisk regresjon.

\begin{tabular}{|c|c|c|c|c|}
\hline & \multicolumn{2}{|c|}{$\begin{array}{l}\text { Bidrag for tradisjonell } \\
\text { organisasjon i } \\
\text { flyktningsituasjonen (2015) }\end{array}$} & \multicolumn{2}{|c|}{$\begin{array}{l}\text { Bidrag for nytt initiativ / } \\
\text { organisert selv } i \\
\text { flyktningsituasjonen (2015) }\end{array}$} \\
\hline & Modell 1 & Modell 2 & Modell 3 & Modell 4 \\
\hline Organisasjonsfrivillig 2014 & $2,13^{\star \star \star}$ & $2,20^{\star \star \star}$ & $3,81^{\star \star}$ & $3,82^{\star \star}$ \\
\hline Kjønn (kvinner) & $1,44 \dagger$ & $1,70^{\star \star}$ & 1,27 & 1,22 \\
\hline \multicolumn{5}{|l|}{ Alder (ref. = 66 år og eldre) } \\
\hline $18-35$ år & $0,56^{\star}$ & $0,60 \dagger$ & $3,46^{\star}$ & $3,39^{\star}$ \\
\hline 36-45 år & $0,39^{\star \star}$ & $0,39^{\star \star}$ & $3,23^{*}$ & $3,33^{*}$ \\
\hline 46-55 år & $0,36^{\star \star \star}$ & $0,32^{\star \star \star}$ & $2,61 \dagger$ & $2,72 \dagger$ \\
\hline $56-65$ år & $0,63 \dagger$ & $0,55^{\star}$ & 1,40 & 1,46 \\
\hline Utdanningsnivå & $1,45^{\star \star \star}$ & & 0,98 & \\
\hline Inntekt & & $1,22^{\star \star}$ & & 0,96 \\
\hline \multicolumn{5}{|l|}{ Partivalg (ref. $=A p)$} \\
\hline Rødt, SV, MDG & $1,67 \dagger$ & $1,79 \dagger$ & $2,22 \uparrow$ & $2,21 \dagger$ \\
\hline Sp, Krf, Venstre & 0,75 & 0,79 & 0,95 & 0,96 \\
\hline Høyre & 0,87 & 0,80 & 0,64 & 0,66 \\
\hline Frp & $0,23^{\star \star}$ & $0,22^{\star \star \star}$ & $0,00^{\star \star \star}$ & $0,00^{\star \star \star}$ \\
\hline Annet parti / ikke stemt & 0,84 & 0,80 & 1,76 & 1,76 \\
\hline Konstant & 0,10 & 0,15 & 0,01 & 0,01 \\
\hline Pseudo r2 & 0,09 & 0,08 & 0,09 & 0,09 \\
\hline $\mathrm{N}$ & 691 & 691 & 691 & 691 \\
\hline
\end{tabular}

Kilde: Norsk medborgerpanel 2016.

Sig. nivå: ${ }^{\dagger} p<0,1,{ }^{*} p<0,05,{ }^{* \star} p<0,01,{ }^{* * *} p<0,001$

Når vi deler inn organisasjonssamfunnet i flere typer organisasjoner, finner vi at rekrutteringen til nye initiativ var særlig sterk blant dem som hadde erfaring med frivillig arbeid for hobby- og fritidsorganisasjoner og for tro- og livssynsorganisasjoner (resultater ikke vist). På tross av den politiske siden ved engasjementet ser vi altså ikke noe tegn på at de som bidro, kom fra mer samfunnsrettede organisasjoner.

\section{Vedvarer engasjementet? Frivillig organisasjonsar- beid høsten 2016}

Det neste spørsmålet er om engasjementet vedvarte. Førte bidrag under flyktningsituasjonen til en mobilisering av nye frivillige i den tradisjonelle frivillige sektoren ett år etter? 


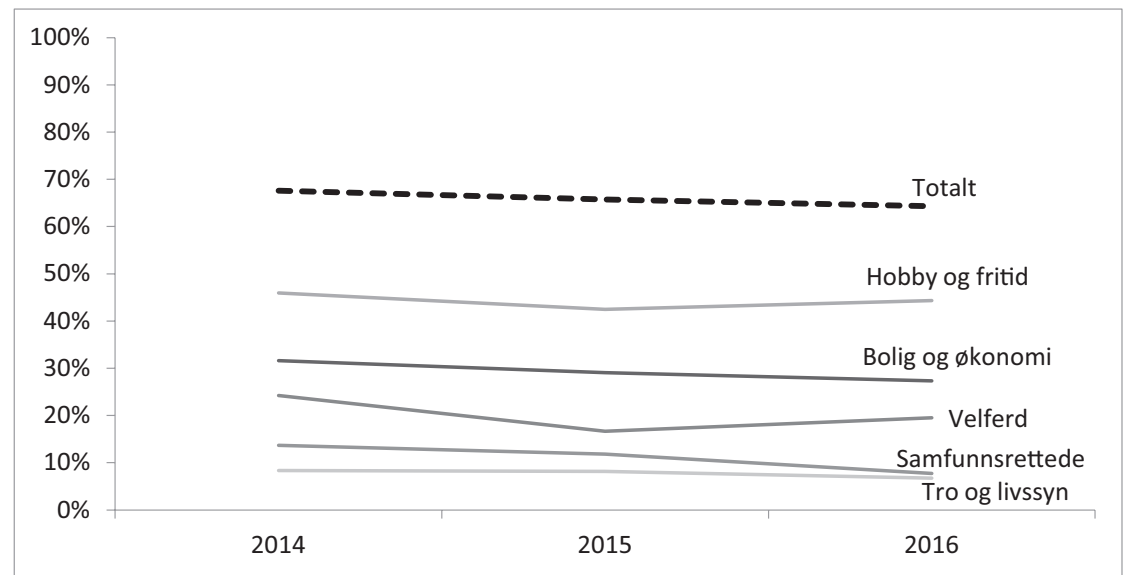

Figur 1: Andel organisasjonsfrivillige over tid. Paneldata. Prosent. Kilde: Norsk medborgerpanel 2014, 2015, 2016. N=636.

Vi begynner med å se på andelen som oppga at de deltok i frivillig organisasjonsarbeid. Figur 1 viser andelen som høsten 2014, høsten 2015 og høsten 2016 deltok i tradisjonelt frivillig arbeid for minst én organisasjon og fordelt på fem organisasjonskategorier. Figuren viser generelt en flat tendens, med små variasjoner i deltakelsesnivået over tid. Andelen som svarte at de hadde deltatt i frivillig arbeid totalt, varierer mellom 64 og 68 prosent. Innenfor feltene velferd, samfunnsrettede og tro og livssyn, som trolig er de mest relevante når det gjelder flyktningrelatert frivillighet, er det heller ingen tegn til økt frivillig deltakelse. Snarere tvert imot: Innenfor velferd og samfunnsrettede organisasjoner var nivået på frivillig innsats noe høyere i 2014 (24 og 14 prosent) enn i 2016 (19 og 8 prosent). Umiddelbart gir altså ikke dette noen indikasjoner på at flyktningsituasjonen bidro til å øke den totale andelen av frivillige i Norge.

Men man må alltid være varsom med å trekke konklusjoner på individnivå basert på aggregert statistikk. Selv om det totale omfanget av frivillige ikke endrer seg, eller til og med går ned, kan det være viktige endringer på individnivå. Man kan for eksempel tenke seg en situasjon der andelen frivillige innenfor rusfeltet synker, mens den øker innenfor flyktningfeltet. Dermed utligner de to trendene hverandre. Vi undersøker derfor om frivillig arbeidsinnsats høsten 2016 på individnivå kan forklares av frivillige bidrag under flyktningsituasjonen, altså om de individene som bidro under flyktningsituasjonen, hadde større sannsynlighet 
Tabell 4. Organisasjonsfrivillig 2016, forklart av bidrag i flyktningsituasjonen og tidligere organisasjonsaktivitet. Odds fra logistisk regresjon.

\begin{tabular}{|l|l|l|l|l|}
\hline & Modell 1 & Modell 2 & Modell 3 & Modell 4 \\
\hline $\begin{array}{l}\text { Flyktningbidrag 2015: tradisjonell } \\
\text { org. }\end{array}$ & 1,36 & & & 1,01 \\
\hline $\begin{array}{l}\text { Flyktningbidrag 2015: nytt initiativ } \\
\text { / organisert selv }\end{array}$ & & 1,30 & & 0,80 \\
\hline Organisasjonsfrivillig 2014 & & & $7,17^{\star \star \star}$ & $7,27^{\star \star \star}$ \\
\hline Kjønn (kvinner) & $0,74 \dagger$ & 0,75 & 0,90 & 0,90 \\
\hline Alder (ref. = 66 år og eldre) & & & & \\
\hline 18-35 år & 0,73 & 0,69 & 0,66 & 0,67 \\
\hline 36-45 år & 1,19 & 1,13 & 1,20 & 1,22 \\
\hline 46-55 år & 1,23 & 1,16 & 1,08 & 1,09 \\
\hline 56-65 år & 0,86 & 0,83 & 0,86 & 0,86 \\
\hline Utdanningsnivå & 1,07 & 1,09 & 1,01 & 1,01 \\
\hline Partivalg (ref. = Ap) & & & & \\
\hline Rødt, SV, MDG & $1,76 \dagger$ & $1,79 \dagger$ & 1,59 & 1,63 \\
\hline Sp, Krf, Venstre & $2,41^{\star \star \star}$ & $2,39 * \star \star$ & $2,00^{\star}$ & $2,00^{\star}$ \\
\hline Høyre & 1,23 & 1,23 & 1,16 & 1,16 \\
\hline Frp & 0,90 & 0,87 & 0,97 & 0,96 \\
\hline Annet parti / ikke stemt & 0,60 & 0,59 & 0,59 & 0,59 \\
\hline Konstant & 1,35 & 1,39 & 0,49 & 0,49 \\
\hline Pseudo r2 & 0,04 & 0,04 & 0,17 & 0,17 \\
\hline $\mathrm{n}$ & 691 & 691 & 691 & 691 \\
\hline Kin & & & \\
\hline
\end{tabular}

Kilde: Norsk medborgerpanel 2016.

Sig. nivå: ${ }^{\dagger} p<0,1,{ }^{\star} p<0,05,{ }^{\star \star} p<0,01,{ }^{\star \star \star} p<0,001$

enn de som ikke bidro, for å delta som organisasjonsfrivillige høsten 2016 (Tabell 4).

Tabell 4 viser en påfallende svak sammenheng mellom bidrag under flyktningsituasjonen høsten 2015 og frivillig organisasjonsarbeid høsten 2016. Modell 1 undersøker effekten av å ha bidratt for en tradisjonell organisasjon under flyktningsituasjonen, mens modell 2 undersøker effekten av å ha bidratt for et nytt initiativ. I begge modellene kontrolleres det for kjønn, alder, utdanning og partivalg. I begge modellene ser vi at det $i k k e$ er en statistisk signifikant sammenheng mellom bidrag i flyktningsituasjonen og frivillig organisasjonsarbeid ett år senere når det kontrolleres for sosial bakgrunn og partivalg. Dette betyr at når vi tar hensyn til disse 
kjennetegnene ved respondentene, hadde ikke de som bidro i flyktningsituasjonen, større sannsynlighet enn andre for å delta i frivillig organisasjonsarbeid ett år senere.

I modell 3 undersøker vi effekten av det å ha deltatt i frivillig organisasjonsarbeid i 2014 på deltakelse i frivillig organisasjonsarbeid i 2016, og her ser vi en sterk positiv sammenheng. De som deltok i frivillig organisasjonsarbeid i 2016, hadde langt større sannsynlighet enn andre for også å ha deltatt i 2014 .

Til sist, i modell 4, undersøker vi alt samlet, altså både ulike bidrag i flyktningsituasjonen og frivillig organisasjonsarbeid i 2014. Denne analysen bekrefter det vi alt har beskrevet. Det er en sterk sammenheng mellom frivillig organisasjonsdeltakelse i 2014 og 2016, men ingen sammenheng mellom bidrag i flyktningsituasjonen og frivillig organisasjonsarbeid i 2016. Dette indikerer at organisasjonene i liten grad evnet å rekruttere nye frivillige fra flyktningsituasjonen. Her er det imidlertid viktig å understreke at enkeltorganisasjoner selvsagt kan ha opplevd økt tilstrømning av frivillige i kjølvannet av flyktningsituasjonen, men flertallet av disse hadde altså tidligere erfaring med frivillig arbeid fra andre organisasjoner.

Interessant nok er det ingen forskjeller knyttet til utdanningsnivå i denne analysen, altså har tilsynelatende ikke høyt utdannede personer større sannsynlighet for å delta i frivillig arbeid enn lavt utdannede. Ved nærmere undersøkelse viser det seg at dette delvis skyldes at effekten av utdanning fanges opp av effekten ved tidligere erfaring som organisasjonsfrivillig - der det allerede er en viss utdanningsskjevhet. Fjerner vi denne variabelen fra analysene, har utdanningsnivå større betydning for sannsynligheten for å delta i frivillig arbeid.

Oppsummert viser analysene i kapitlet fire generelle tendenser. For det første skjedde mobiliseringen under flyktningsituasjonen særlig blant tidligere frivillige. For det andre bidro nye frivillige initiativ til å rekruttere enkelte grupper som tradisjonelt er underrepresentert i frivilligheten. For det tredje hadde bidrag i flyktningsituasjonen en tydelig politisk tendens. Og for det fjerde bidro flyktningsituasjonen i begrenset grad til å rekruttere nye frivillige inn i det tradisjonelle organisasjonslivet. Vi diskuterer disse funnene nærmere i siste avsnitt. 


\section{Diskusjon og konklusjon}

Flyktningsituasjonen høsten 2015 er en velegnet case for å studere nye kollektive handlingsformer. Sivilsamfunnet mobiliserte mange frivillige, og nye frivillige initiativ oppstod.

Analysene i dette kapitlet gir noe støtte til både mobiliseringshypotesen og forsterkningshypotesen. Sammenlignet med de tradisjonelle organisasjonene tiltrakk de nye initiativene seg relativt sett flere unge, flere lavt utdannede og flere med lav inntekt. På denne måten ble grupper som tradisjonelt er underrepresentert i frivilligheten, engasjert i den aktuelle perioden. Samtidig så vi også at blant dem som engasjerte seg i de nye initiativene, var det en klar overvekt av personer som hadde erfaring med frivillig organisasjonsarbeid i 2014 - året før flyktningsituasjonen. Og blant dem som bidro i regi av tradisjonelle organisasjoner, fant vi de samme utdannings- og inntektsskjevhetene som vi finner innenfor tradisjonell frivillig innsats (Folkestad mfl., 2015). Dette indikerer at «nyrekrutteringen» var begrenset, og at mobiliseringen i flyktningsituasjonen også bar preg av en forsterkning av eksisterende skiller.

Én mulig forklaring på den manglende mobiliseringen av nye frivillige kan være knyttet til flyktningsituasjonens politiske dimensjon. Analysene viste at mobiliseringen under flyktningsituasjonen ikke var veldig bred når vi tar hensyn til politiske oppfatninger. Velgergrupper som støtter partier med en liberal flyktningpolitikk, bidro i langt større grad enn velgergrupper som ønsker en restriktiv flyktningpolitikk (jf. Aardal, 2003, 2015). En tolkning av dette er at frivillige bidrag i flyktningsituasjonen i mange tilfeller må forstås som politisk aktivisme snarere enn frivillig innsats (Eliasoph, 2013). Dermed mobiliseres politisk engasjerte mennesker, som ofte har erfaring fra organisasjonslivet. Den mest nærliggende tolkningen er å anse bidragene som en kombinasjon av de to formene. På den ene siden oppstod det i flyktningsituasjonen akutte samfunnsproblemer som måtte løses, blant annet utenfor Politiets utlendingsenhet på Tøyen, noe som både mobiliserte tradisjonelle frivillige organisasjoner, og som bidro til opprettelsen av nye initiativ med mer spontane former for frivillighet (jf. Simsa mfl., 2018). På den andre siden var enkelte av de nye initiativene tydelig politisk motivert, blant annet ved å gjennomføre aksjoner og demonstrasjoner mot regjeringens flyktningpolitikk 
(Sætrang, 2016, s. 50-51); en form for frivillig humanitærisme (Sandri, 2018). Denne sammenblandingen av frivillig innsats og politisk aktivisme ligner således mer på den tradisjonelle folkebevegelsesmodellen i Norge, der frivillig innsats (eller aktivt organisasjonsmedlemskap) ofte var basert på tilhørighet til et politisk kollektiv (Wollebæk \& Selle, 2008). Men som påpekt innledningsvis i kapitlet sprang ikke engasjementet ut fra en eller noen få store folkebevegelser. Snarere var det saken (hjelpe flyktninger) og aktivitetene som stod i sentrum, ikke hvilke rammer de foregikk innenfor. Noen engasjerte seg i etablerte organisasjoner, andre i nye initiativ, og atter andre organiserte innsatsen selv. Mye av engasjementet i flyktningsituasjonen er således gode illustrasjoner på mer refleksive former for frivillighet, der det er aktiviteten og ikke organisasjonen som står i sentrum (jf. Hustinx \& Lammertyn, 2003).

Til slutt har vi sett at mobiliseringen under flyktningsituasjonen i liten grad påvirket den tradisjonelle organisasjonsfrivilligheten. Det overordnede nivået på antallet frivillige holdt seg stabilt i perioden 2014-2016, og frivillig organisasjonsarbeid høsten 2016 kan i liten grad forklares av frivillige bidrag under flyktningsituasjonen høsten 2015. Det ser derfor ikke ut til at organisasjonene på lengre sikt har klart å rekruttere nye grupper frivillige blant dem som bidro i flyktningsituasjonen. Som påpekt $i$ analysene betyr dette selvsagt ikke at enkeltorganisasjoner ikke har fătt nye frivillige i kjølvannet av flyktningsituasjonen, men disse frivillige hadde $\mathrm{i}$ overveiende grad vært frivillige i andre organisasjoner i 2014.

En samlet tolkning av disse funnene sett opp mot de to overordnede hypotesene, er at vi må skille mellom korttidsmobilisering og langtidsforsterkning. Selv om mange av dem som bidro under flyktningsituasjonen høsten 2015, hadde erfaring fra frivillig organisasjonsarbeid, og selv om de gjerne hadde bestemte politiske oppfatninger, er det ikke til å underslå at det også var mange nye frivillige blant dem som bidro. Dette viser at sivilsamfunnet på kort sikt evnet å mobilisere mange, både eksisterende og nye frivillige. Denne type korttidsmobilisering kan ses i sammenheng med mer generelle utviklingstrekk i sivilsamfunnet, der refleksiv, spontan og ad hoc-basert frivillighet blir vanligere på bekostning av den tradisjonelle medlemsbaserte frivilligheten (Hustinx \& Lammertyn, 2003). Over tid har medlemskap og organisasjonstilhørighet blitt mindre 
viktig, mens indre motivasjon og interesse har fått økt betydning (Wollebæk mfl., 2015). Korttidsmobiliseringen ser imidlertid ikke ut til å ha endret sammensetningen av sivilsamfunnet på lengre sikt. Den suverent viktigste forklaringen på om man deltok i frivillig arbeid høsten 2016, var at man også deltok i frivillig arbeid høsten 2014. På lengre sikt ser vi dermed en vedvarende forsterkning, eller i det minste opprettholdelse, av forskjeller mellom frivillige og ikke-frivillige.

Et slikt skille mellom korttidsmobilisering og langtidsforsterkning viste seg uansett å fungere godt høsten 2015. Sivilsamfunnets styrke var helt avgjørende for det norske samfunnets robusthet i møtet med den økte tilstrømningen av asylsøkere. Situasjonen viste således styrken i å ha et omfattende sivilsamfunn med et grunnfjell bestående av mange kjernefrivillige, der andre kan komme til å bidra i kortere perioder. Det offentlige mottaksapparatets manglende kapasitet hadde kanskje blitt enda tydeligere dersom Norge hadde hatt et svakere sivilsamfunn.

\section{Referanser}

Aardal, B. (2003). Ideologi og stemmegivning. I B. Aardal (Red.), Velgere i villrede ... En analyse av stortingsvalget 2001. Oslo: Damm.

Aardal, B. (2015). Politiske verdier og stemmegivning. I B. Aardal \& J. Bergh (Red.), Valg og velgere. En studie av stortingsvalget 2013. Oslo: Cappelen Damm.

Arnesen, D. (2015). Undersøkelsene om frivillig innsats 1998-2014. Dokumentasjonsrapport. Rapport 3/2015. Oslo/Bergen: Senter for forskning på sivilsamfunn og frivillig sektor.

Drabek, T. E., \& McEntire, D. A. (2003). Emergent phenomena and the sociology of disaster: Lessons, trends and opportunities from the research literature.

Disaster Prevention and Management: An International Journal, 12(2), 97-112. doi:10.1108/09653560310474214

Eimhjellen, I., \& Ljunggren, J. (2017). Kollektiv handling i digitale medier. Nye digitale skiller? Rapport 3/2017. Bergen/Oslo: Senter for forskning på sivilsamfunn og frivillig sektor.

Eliasoph, N. (2013). The Politics of volunteering. Cambridge: Polity.

Fladmoe, A., Sætrang, S., Eimhjellen, I., Steen-Johnsen, K., \& Enjolras, B. (2016). Nordmenns bidrag i flyktningsituasjonen 2015/16. Rapport 6/2016. Bergen/Oslo: Senter for forskning på sivilsamfunn og frivillig sektor.

Folkestad, B., Christensen, D. A., Strømsnes, K., \& Selle, P. (2015). Frivillig innsats i Noreg 1998-2014. Kva kjenneteikner dei frivillige og kva har endra seg? Rapport 4/2015. Bergen/Oslo: Senter for forskning på sivilsamfunn og frivillig sektor. 
Greussing, E., \& Boomgaarden, H. G. (2017). Shifting the refugee narrative? An automated frame analysis of Europe's 2015 refugee crisis. Journal of Ethnic and Migration Studies, 43(11), 1749-1774. doi:10.1080/1369183X.2017.1282813

Hustinx, L., \& Lammertyn, F. (2003). Collective and Reflexive Styles of Volunteering: A Sociological Modernization Perspective. Voluntas: International Journal of Voluntary and Nonprofit Organizations, 14(2), 167-187. doi:10.1023/A:1023948027200

Musick, M. A., \& Wilson, J. (2008). Volunteers: A social profile. Bloomington and Indianapolis: Indiana University Press.

Norris, P. (2001). Digital divide : civic engagement, information poverty, and the Internet worldwide. Cambridge: Cambridge University Press.

Rokkan, S., Hagtvet, B., \& Alldén, L. (1987). Stat, nasjon, klasse: essays i politisk sosiologi. Oslo: Universitetsforlaget.

Sandri, E. (2018). 'Volunteer Humanitarianism': Volunteers and humanitarian aid in the Jungle refugee camp of Calais. Journal of Ethnic and Migration Studies, 44(1), 65-8o. doi:10.1080/1369183X.2017.1352467

Simsa, R., Rameder, P., Aghamanoukjan, A., \& Totter, M. (2018). Spontaneous Volunteering in Social Crises: Self-Organization and Coordination. Nonprofit and Voluntary Sector Quarterly. doi:10.1177/0899764018785472

Sætrang, S. (2016). "Ikke bare en Facebook-gruppe". En case-studie av Refugees Welcome-nettverket $i$ Norge. Rapport 9/2016. Bergen/Oslo: Senter for forskning på sivilsamfunn og frivillig sektor.

Wollebæk, D., \& Selle, P. (2008). A social democratic model of civil society? I B. Jobert \& B. Kohler-Koch (Red.), Changing Images of Civil Society: From Protest to Governance. London: Routledge.

Wollebæk, D., \& Sivesind, K. H. (2010). Fra folkebevegelse til filantropi. Frivillig innsats i Norge 1997-2009. Rapport 3/2010. Oslo/Bergen: Senter for forskning på sivilsamfunn og frivillig sektor.

Wollebæk, D., Sætrang, S., \& Fladmoe, A. (2015). Betingelser for frivillig innsats. Motivasjon og kontekst. Rapport 1/2015. Bergen/Oslo: Senter for forskning på sivilsamfunn og frivillig sektor. 


\title{
På Facebook for flyktninger. En casestudie av Refugees Welcome-nettverket i Norge
}

\author{
Synne Sætrang \\ Kirkens Bymisjon
}

\begin{abstract}
Based on interviews with seven leaders and key figures in six different initiatives across the country, the chapter analyses the emergence and development of the Refugees Welcome-initiative in Norway. The aim of the study is to gain insight into the groups' transformation from loose digital networks to becoming more or less formal organizations, providing a unique approach to understand the emergence and development of a social movement. By using a multi-dimensional approach, the study analyses how political opportunity structures, cultural framing and mobilizing structures-and the interaction between them-contributed to the emergence, rapid growth and development of RW. The chapter highlights the opportunities and challenges of a decentralized and informal organizational form, and how the potential of digitalization is conditioned by both internal needs for control and oversight, and external (legal) requirements and expectations.
\end{abstract}

Keywords: volunteering, voluntary organizations, new voluntary initiatives, social media, refugees, Refugees Welcome, Refugees Welcome to Norway

Sitering av denne artikkelen: Sætrang, S. (2018). På Facebook for flyktninger. En casestudie av Refugees Welcome-nettverket i Norge. I B. Enjolras \& I. Eimhjellen (Red.), Fra kollektiv til konnektiv handling? Nye former for samfunnsengasjement og kollektiv handling i Norge (s. 151-187). Oslo: Cappelen Damm Akademisk. https://doi.org/10.23865/noasp.45.ch6 Lisens: CC BY-NC 4.0 


\section{Innledning}

Da et stort antall flyktninger og asylsøkere ankom Norge høsten og vinteren 2015, vekket situasjonen et stort engasjement i det norske sivilsamfunnet. Aldri før har det kommet så mange mennesker til Norge på så kort tid. Som vi så i forrige kapittel, bidro flertallet av de frivillige gjennom etablerte organisasjoner, men situasjonen førte også til fremveksten av nye hjelpegrupper.

De første som ankom ble alle sendt til registrering på Politiets Utlendingenhet (PU), som nylig hadde flyttet inn i nye kontorer på Tøyen. De mange ankomstene førte til at registreringskontoret raskt ble overbelastet. Det hopet seg opp med mennesker i de små lokalene, og det dannet seg lange køer utenfor. Den ekstraordinære situasjonen fikk stor oppmerksomhet i mediene, som skildret hvordan et stort antall mennesker måtte sove på gulvet på venterommet, uten tilgang til dusj og et varmt måltid.

Inspirert av en internasjonal RW-bevegelse som hadde fulgt flyktningene gjennom Europa ${ }^{1}$, opprettet en gruppe kunstnere som var innom PU hver dag med mat og hygieneartikler Facebook-gruppen Refugees Welcome to Norway (RWTN) i slutten av august. Målet med gruppen var å dra i gang en aksjon for å få flere til å engasjere seg for flyktningene. Stadig flere sluttet seg til det nyopprettede initiativet ved å bli medlem av gruppen og/eller bidra med frivillig innsats og donasjoner. Etter to uker hadde gruppen 60 ooo medlemmer, og i løpet av de neste månedene vokste den til om lag 90 ooo. Mobiliseringen på Tøyen vekket ikke bare oppmerksomhet i hovedstaden. I ukene som fulgte dukket lignende Facebook-grupper opp, i ulike lokale og regionale varianter, i takt med at asylmottak og midlertidige mottaksplasser ble opprettet over hele landet (Refugees Welcome to Østfold, Moss, Søndre Nordstrand osv). På Norway-gruppens hjemmesider var det på undersøkelsestidspunktet registrert 61 lokale RW-grupper på landsbasis². Gruppenes aktiviteter har i

$1 \quad$ Initiativer med likelydende navn hadde allerede blitt opprettet $\mathrm{i}$ andre europeiske land, med opphav i Tyskland. Les mer om Refugees Welcome International på refugees-welcome.net.

2 I tillegg kommer ulike spesialgrupper med likelydende navn (Refugees Welcome to School, Health osv). I sin webstudie av flyktningengasjementet på sosiale medier finner Ivar Eimhjellen (2016) nær 100 RW-initiativer. 
hovedsak dreiet seg om akutthjelp ved ankomst i form av utdeling av mat og utstyr til nyankomne, organisering av sosiale aktiviteter både i og utenfor mottak, samt aksjoner og demonstrasjoner for å vekke oppmerksomhet rundt flyktningers situasjon og rettigheter.

Gitt deres tilsynelatende uformelle organisering, overrasket flere av RW-gruppene mange ved å ikke bare være et «blaff», men forbli aktive og til og med bygge styrke over tid - ved hjelp av både online- og offlineaktiviteter. På intervjutidspunktet var flere av gruppene også i en overgang fra å være løse digitale nettverk til å bli mer eller mindre formelle organisasjoner. Målet med kapitlet er å få innblikk i disse institusjonaliseringsprosessene, fra spontan handling til mer formelle former for organisering.

At frivillige sammenslutninger organiserer seg for å løse nye og påtrengende samfunnsproblemer eller bedre betingelsene for særskilte grupper i samfunnet, er ikke noe nytt. Mange av de store sosiale og humanitære organisasjonene som vokste frem mot slutten av 180o-tallet, ble også etablert for å gripe fatt i samfunnsoppgaver som det offentlige ikke hadde vilje eller kapasitet til å håndtere. I RWs tilfelle er det formen, omfanget og hastigheten på mobiliseringen som fremstår som noe særegent. Med utbredelsen av internett og sosiale medier lever vi i en tid da individers muligheter til å dele, samarbeide og handle kollektivt har økt kraftig - både innenfor og utenfor rammene av tradisjonelle institusjoner og strukturer.

Når vi i denne boken setter fokus på hvordan fenomener som individualisering, globalisering og digitalisering bidrar til å endre vilkårene for frivillig mobilisering og organisering, utgjør RW en interessant case: En ren digital bevegelse vokser frem på siden av de etablerte organisasjonene og finner nye måter å løse samfunnsproblemer på. Men spørsmål om organisering kommer raskt på dagsorden. I analysene benyttes sosial bevegelsesteori for å belyse sentrale betingelser for RW-gruppenes fremvekst og utvikling. Kapitlet reiser sentrale spørsmål om hvorvidt RW kan sies å representere en ny organisasjonsform som skiller seg fra mer tradisjonelle former for kollektiv handling, og om bærekraften i denne typen løse, digitale nettverk i en norsk sammenheng. Før vi går nærmere inn på analysene gis en kort redegjørelse for bakgrunnen for studien og det teoretiske rammeverket, samt studiens data- og metodebakgrunn. 


\section{Nye sosiale bevegelser - en flerdimensjonal tilnærming}

Når dette kapitlet studerer RW-gruppers fremvekst og utvikling, gjøres det i lys av analytiske verktøy utviklet for å studere sosiale bevegelser, eller såkalte «New Social Movements» (NSM). I bred forstand kan en sosial bevegelse defineres som «et nettverk av uformell interaksjon over tid mellom et mangfold av individer, grupper og/eller organisasjoner, som inngår i en politisk eller kulturell konflikt på basis av en delt identitet» (Diani, 1992:12, forfatterens oversettelse).

Når man snakker om «nye» sosiale bevegelser er man gjerne opptatt av organiseringsformer som er forskjellige fra de som var, først og fremst de tradisjonelle folkebevegelsene som vokste frem på 180o- og 1900-tallet, som arbeiderbevegelsen og lignende typer organisasjoner knyttet til klart definerte økonomiske grupper. Disse vokste gjerne ut av en tydelig kollektiv identitet eller ideologi, og var kjennetegnet av en hierarkisk organisering som bandt det lokale, regionale og nasjonale nivået sammen, og med kommunikasjons- og styringsprosesser som løp gjennom disse (Enjolras, 2010) ${ }^{3}$.

Et sentralt trekk ved nye sosiale bevegelser - og som ligger til grunn for den brede definisjonen som benyttes i dette kapitlet - er ikke at de arbeider for endring eller at kampsakene er noen helt andre enn tidligere, men at de gjør det utenfor rammene av etablerte institusjoner (Stalder, 2006; Snow \& Soule, 2010). På grunn av de endrede betingelsene for organisering som den teknologiske utviklingen muliggjør, er nye sosiale bevegelser gjerne preget av en større grad av desentralisering, som typisk oppstår ved nettverksorganisering. Som et resultat av dette har mange en flat struktur, som lav grad av hierarkiske strukturer, og ikke nødvendigvis klare, vertikale roller. De er ofte saksbaserte, fremfor å følge tradisjonelle politiske skillelinjer, og dynamiske i form av mennesker som glir inn og ut ettersom mulighetene for aktivitet og engasjement byr seg (ingen definert medlemsmasse eller tydelig skille mellom medlem og ikke-medlem).

3 «Nye sosiale bevegelser» blir gjerne benyttet om fremveksten av nye typer bevegelser som vokste frem på 6o- og 70-tallet og i økende grad fokuserte på saker grunnet i identitet og livsstil, som miljø, fred, etnisitet, kjønn og New Age, fremfor klasse og ideologi. 
Mens organisasjoner tidligere var helt nødvendige for å spre informasjon og mobilisere til kollektiv handling i stor skala, representerer internett og sosiale medier en alternativ og mindre ressurskrevende infrastruktur for sosialisering, organisering og handling der informasjon kan spres umiddelbart til svært mange og koble og mobilisere individer på en mye raskere måte enn før (Shirky, 2008; Barrabasi, 2002; Enjolras, Steen-Johnsen \& Wollebæk, 2013). Som beskrevet i bokens introduksjonskapittel, er det basert på disse egenskapene ved digitale medier at Bennet og Segerberg (2012) har argumentert for at nye former for konnektiv («connective») handling vil komme til å supplere, og delvis erstatte, tradisjonelle organiseringsformer.

I mye av organisasjonsteorien har prosessen fra spontane bevegelseslignende samlinger til hierarkiske, byråkratiske organisasjoner tidligere blitt beskrevet nesten som en lovmessighet, der institusjonalisering blir ansett som en lineær prosess fra det spontane mot mer differensiering (arbeidsdeling og profesjonalisering) og formalisering (utvikling av (u) formelle regler) ${ }^{4}$. Bennet og Segerberg (2012) argumenterer imidlertid for at det er grunn til å anta at det ikke lenger er en automatikk i dette, fordi ny kommunikasjonsteknologi grunnleggende har endret betingelsene for kollektiv handling. I det de omtaler som en konnektiv handlingslogikk, organiseres sivilt engasjement gjennom sosiale medie-nettverk, noe som ikke krever store administrasjonsressurser, eller formelle og byråkratiske organisasjonsstrukturer. Ikke bare senker det kostnadene ved frivillig organisering drastisk, det muliggjør også en mer personifisert («personalized») form for kollektiv handling, som krever mindre av deltakerne i form av tilslutning til bestemte ideologier eller identiteter enn mer tradisjonelle former for organisering basert på sosial gruppetilhørighet eller medlemskap (Bennet \& Segerberg, 2012). Ved at mennesker fra et mangfold av bakgrunner kan komme sammen på digitale plattformer for en felles sak, og videre mobilisere direkte i sine nettverk via egen profil, som et personlig uttrykk, appellerer en konnektiv form i større grad

4 Den mest berømte av slike teorier er Michels (1962) om «oligarkiets jernlov», som ifølge Seippel (2003) «skaper et inntrykk av at alle bevegelser ubønnhørlig vil utvikle seg i retning av byråkrati og oligarki». I organisasjonsteorien betegnes tendenser til homogenisering av organiseringsformer som «institusjonell isomorfisme» (DiMaggio \& Powell, 1991). 
til stadig mer individualiserte og «refleksive» frivillige (se Hustinx \& Lammertyn, 2003).

Det er viktig å understreke at det som i mye av litteraturen omtales som «nye» og «tradisjonelle» organiseringsformer og logikker ikke er gjensidig utelukkende; i praksis snakker man gjerne om grader av formalisering og sentralisering, eller «hybrider», når man skiller mellom ulike organiseringstyper (se bl.a. Enjolras, 2010; Bennet \& Segerberg 2012; Eimhjellen, 2016b). På grunn av mangfoldet av organiseringsformer er det i dag enda vanskeligere - og derfor mindre fruktbart - å studere nye aktører i lys av etablerte kategorier. Dette er noe av grunnen til at man de siste tiårene har sett en dreining i NSM-litteraturen mot en mer dynamisk forstålse av institusjonalisering som en flerdimensjonal prosess, der både strukturelle, kulturelle og organisatoriske faktorer påvirker sosiale bevegelsers fremvekst og utvikling 5 . Det er en slik tilnærming som ligger til grunn for analysene i dette kapitlet.

\section{Politiske mulighetsstrukturer, mobiliseringsstrukturer og forståelsesrammer}

Med bakgrunn i en flerdimensjonal tilnærming ser analysen nærmere på tre sett av faktorer. Politiske mulighetsstrukturer («Political opportunity structure»), det strukturelle feltet der bevegelsene opererer, og som former mulighetene for kollektiv handling og formen bevegelsen tar. Mobiliseringsstrukturer («mobilizing structure»), de sosiale nettverkene, organisasjonsstrukturene og aktivitetsmønstrene som utgjør basis for selve bevegelsen, og forståelsesrammer («cultural framing» ${ }^{6}$ ): den kulturelle forståelsen knyttet til dem som deltar i bevegelsene, og som preger den sammenhengen man er aktiv i (McAdam mfl., 1996; Seippel, 2003).

5 Perspektivet kombinerer flere ulike teoretiske perspektiver, som f.eks. politisk mulighetsteori, ressursmobiliseringsteori og symbolsk interaksjonisme (se bl.a. Della Porta \& Diani, 2006; McAdam mfl., 1996, Seippel, 2001 og 2003; Snow \& Soule, 2010).

6 Framing-begrepet er lånt fra Erving Goffmans (1974) teoretiske arbeider, hvor rammer defineres som tolkningsskjemaer («schemata of interpretation») som hjelper individer å «locate, percieve, identify and label occurences within their life space and the world at large» (referert i Della Porta og Diani, 2006, s. 74). 
Ved å se på mulighetsstrukturene, eller feltet de opererer i, erkjenner man at en bevegelse eller et initiativ ikke eksisterer uavhengig av omgivelsene de er en del av. De politiske mulighetsstrukturene består blant annet av rammer, krav og påvirkning fra myndigheter, institusjoner, etablerte frivillige aktører og meningsmotstandere. I analysen av RW gjør disse seg særlig gjeldende når det er snakk om rommet for en ny og uformell aktør i akuttfasen, og i videre utvikling ved at formelle krav etter kort tid fører til at flere av gruppene raskt blir formelle organisasjoner. Når det gjelder mobiliseringsstrukturene, er ressurser (materielle, menneskelige, sosiale, moralske og kulturelle) og organisering sentralt (Snow \& Soule, 2010). Av de tre dimensjonene er det denne som får størst plass i analysene, på grunn av at RWs bruk av internett til mobilisering og organisering på en grunnleggende måte preger både deres fremvekst og videre organisering. Selv om mobiliseringsstrukturer og muligheten til å handle og uttrykke seg er essensielt for å forstå en sosial bevegelse, er det for å få en bredere forståelse også nødvendig å få et grep om meningen aktørene knytter til deltakelsen og engasjementet. Å få et grep om forståelsesrammene til de som deltar er en helt sentral del av analysen i denne studien, fordi den meningen aktørene knytter til situasjoner og hendelser påvirker både hvordan de opplever mulighetene for handling (mulighetsrom er ingen objektiv størrelse), og hvilke virkemidler som er mest effektive for å hanskes med utfordringene. I tråd med Bennet og Segerbergs (2012) konnektive handlingslogikk innebærer ikke en slik felles forståelsesramme oppslutning rundt en spesifikk ideologi eller identitet. Den kan snarere knytte til seg individer og grupper med et mangfold av ulike orienteringer. Med en felles forståelse av konkrete hendelser og problemer som samler dem (f.eks. «vi» som vil gjøre noe for flyktninger), bidrar den til å mobilisere til kollektiv handling. Slike framingprosesser, der spesifikke forståelsesrammer oppstår, er i kontinuerlig utvikling i møte med interne og eksterne ideer og orienteringer. I RWs tilfelle skal vi se hvordan forstålsesrammene gjør seg gjeldene både i mobiliseringsfasen (gjennom informantenes beskrivelser av hva som engasjerte så mange mennesker til å gjøre noe for de mange nyankomne flyktningene) og videre hvordan de som en ny og uformell aktør utfordrer rådende forståelser av hva en legitim aktør på asyl- og flyktningfeltet er og bør være.

De tre dimensjonene vil være sentrale i studien av RW, for å utforske hvordan en gruppe menneskers engasjement kunne spre seg så raskt og 
mobilisere så mange på så kort tid. Analysene synliggjør hvordan dimensjonene preget gruppenes videre utvikling etter den første spontane organiseringen, og hvordan de er nyttige i diskusjonen av mulighetene og utfordringene ved en løs og uformell organiseringsform.

\section{Data og metode}

Analysene i dette kapitlet er basert på intervjuer med syv sentrale aktører i seks RW-initiativer rundt om i landet: to landsdekkende og fire lokalgrupper. Intervjuene ble utført i perioden februar til juni 2016. Et kriterium har vært at utvalget skal representere variasjon og bredde, og initiativene i undersøkelsen er derfor forskjellige både når det gjelder størrelse, struktur og arbeidsområder. Informantene holder til på Østlandet, Sørlandet og i Nord-Norge. Dette er blant de områdene som opplevde størst pågang av flyktninger og asylsøkere høsten 2015 (se Fladmoe mfl., 2016).

De første casene ble valgt på grunnlag av informasjon fra deres Facebook-sider og via mediesøk, der de fremstod som en typisk harmoni- og konfliktcase. Mens den ene RW-gruppen fremstod som en sentral aktør i koordineringen av asyl- og flyktningfeltet i sitt fylke, hadde den andre gruppen opplevd utfordringer med å slippe til for å bidra på et nyopprettet mottak i lokalmiljøet. I tillegg til disse intervjuet jeg to andre lokalgrupper som ble nevnt i de første intervjuene, samt Refugees Welcome to Norway og Refugees Welcome to the Arctic. Gruppene i utvalget varierer også når det kommer til aktivitetsområder. Mens lokalgruppene i hovedsak driver med koordinering av frivillige og aktiviteter på lokale mottak, jobber Norway-gruppen i større grad med informasjonsarbeid og opp mot myndighetsnivå. Arctic skiller seg ut som en aksjonsgruppe, opprettet i forbindelse med utsendelsene over grensa til Russland vinteren 2015/2016.

Fem av de seks gruppene i utvalget hadde på intervjutidspunktet registrert seg som frivillig organisasjon i Brønnøysundregistrene, og jobbet med å få på plass et styre og demokratiske strukturer. På landsbasis er de færreste organisasjonene formalisert (gjaldt per 15.12.2016 kun 11 av 61 registrerte grupper). Informantene i utvalget er utelukkende kvinner7,

7 De aller fleste ildsjelene bak lokale RW-initiativer er kvinner. En av informantene beskriver RW som et «kvinnedrevet initiativ». 
i alderen 31 til 65 år. Samtlige har vært sentrale i opprettelse og/eller utvikling av sine respektive initiativer, og hadde på intervjutidspunktet ledende funksjoner i sin lokalgruppe - enten som leder, koordinatorer og/ eller styremedlem. Enkelte av informantene er involvert i flere av gruppene i utvalget.

Det er verdt å bemerke at dataene er basert på individintervjuer, mens analysene i stor grad omfatter organisasjonsnivået. Når man studerer sosiale bevegelser med en tilnærming der aktørenes forståelsesrammer er en vesentlig faktor, er ikke målet å gripe en «objektiv» virkelighet. Organisatoriske karakteristikker blir derfor belyst gjennom informantenes subjektive erfaringer og opplevelser. At det er snakk om informantenes egne erfaringer og oppfatninger er særlig viktig å ha i bakhodet når de sammenligner seg med andre aktører for å tydeliggjøre RWs særtrekk og identitet.

En annen viktig presisering er at undersøkelsen er basert på ett intervjutidspunkt. Siden intervjuene har enkelte av gruppene i utvalget endret organiseringsform. Blant annet har to av gruppene blitt medlemsorganisasjoner og har gjennomført demokratiske valg av styrer. Noen er i gang med nye arbeidsområder, mens andre er mer eller mindre inaktive som følge av at lokale mottak de var tilknyttet på intervjutidspunktet er lagt ned ${ }^{8}$.

Alle informanter er anonymisert i teksten. Lokalgruppene er anonymisert, mens Refugees Welcome to Norway og Refugees Welcome to the Arctic er vanskeligere å anonymisere på grunn av deres særegne kjennetegn. Andre organisasjoner, aktører og enkeltpersoner som trekkes frem i intervjuene er anonymisert, da de ikke har hatt anledning til å samtykke. Prosjektet er meldt inn til Norsk senter for forskningsdata (NSD).

\section{Fremveksten av en sosial bevegelse}

Som beskrevet innledningsvis, var det få som hadde forutsett omfanget av flyktning- og asylankomster høsten 2015. Tilstandene utenfor PU på Tøyen var kaotiske, og snart opplevde flere lokalsamfunn rundt om i

8 Se «Etterord» i Sætrang, 2016 for mer informasjon om gruppenes utvikling i etterkant av intervjuene. 
landet lignende tilstander etter hvert som lokale mottak ble opprettet og store antall mennesker ankom på kort tid.

Hvordan gikk det til at en liten gruppe frivillige som delte ut mat til flyktningene utenfor PU på Tøyen vokste til en Facebook-gruppe med nær 100 ooo medlemmer, og lokalgrupper over hele landet? Et første steg $\mathrm{i}$ å få grep om RW-bevegelsens fremvekst og raske spredning er å undersøke informantenes egne beskrivelser av situasjonen og hvilken mening de knyttet til denne. Det handler altså om å få tak på det Seippel (2003) betegner som aktørenes forståelsesrammer, forstått som meningen aktørene knytter til deltakelsen og engasjementet rundt flyktningsituasjonen.

\section{«Den varme bølgen»}

En av Oslo-informantene forteller om hvordan de store behovene som ble synliggjort utenfor PU førte til at Refugees Welcome to Norway i løpet av kort tid utviklet seg fra å være et middagsserveringsinitiativ til å organisere storskala innsamlinger av klær, hygieneartikler og utstyr til de nyankomne.

[...] Veldig mange kom jo i det de stod og gikk i. De hadde jo ikke med seg noe. Altså...deodorant, tannbørste, shampoo...de hadde jo ingenting! Så det ble litt sånn: Ok, her kommer det folk helt tomhendte og de står sånn 200 meter fra der jeg bor. Også så mange! På det meste kom det jo flere hundre om dagen.

En annen Oslo-informant beskriver hvordan de benyttet Facebookgruppen for fortløpende koordinering av innsamling av klær og utstyr og formidling av raskt endrede behov etter hvert som nye grupper ankom.

Det var litt sånn «Vi har klær, har noen andre klær?» For det var folk [nyankomne, forskers anm.] som kom med bare de det hadde på seg. Det var unger som hadde ulike behov, det var liksom....det manglet bleier, altså...you name it. Så det var litt sånn... «hvem har bleier?» Ok, hun har bleier. «Hvem har morsmelkerstatning?» Fint, du har morsmelkerstatning [...].

På grunn av stor pågang fra folk som ønsket å bidra måtte det nyopprettede initiativet finne seg lokaler for oppbevaring. De fikk etter hvert sponset et stort lokale på Tøyen der de samlet inn store mengder klær 
og utstyr fra engasjerte Oslo-beboere. En informant forteller om en overveldende pågang ved den første innsamlingen i de nye lokalene, og at de i løpet av få dager samlet inn «flere tonn» med donasjoner. Den første dagen var det kun et par mennesker på plass for å ta imot klær, men under innsamlingen spurte flere om de kunne bidra, og andre dagen talte de mer enn 130 frivillige som bidro med innsamling og sortering på lageret.

I takt med at asylmottak og midlertidige mottaksplasser ble opprettet rundt om i landet, dukket lignende Facebook-grupper opp, i ulike lokale og regionale varianter. Når informantene omtaler RW-initiativets fremvekst på Tøyen og den raske spredningen til hele landet, er det flere som knytter utviklingen til den omfattende oppmerksomheten rundt flyktningsituasjonen i både sosiale og tradisjonelle medier. For flere synes spredningen av bildet av Aylan Kurdi, en tre år gammel gutt som ble funnet druknet i vannkanten på en strand, som en hendelse som gjorde at man forstod alvoret i situasjonen, og som for flere utløste en opplevelse av at «nok er nok» ${ }^{9}$. Kombinasjonen av medienes vinkling av en internasjonal krisesituasjon og dekningen av frivilliges bidrag på Tøyen synes altså å ha trigget folks vilje til å gjøre noe aktivt for flyktninger ${ }^{10}$.

Når informantene forteller om sin vei inn i RW, er det imidlertid ikke den omfattende mediedekningen i seg selv som vektlegges, men snarere holdningene og perspektivene som preget den offentlige debatten de store kontrastene i fremstillingene: Kombinasjonen av historier om hjelpeløse skjebner og det de omtaler som en stadig økende skepsis til flyktninger og innvandrere, vekket deres motivasjon for å gjøre noe. En gjennomgående tendens $\mathrm{i}$ informantenes fortellinger at de over tid hadde reagert på et debattklima preget av det de oppfattet som en stadig større aksept for nedlatende og hatefulle kommentarer om innvandring og flyktninger, samtidig som man så bilder av små barn og familier som

9 Se bl.a. Prøytz, Lin (2016). The strength of weak commitment: A Norwegian response to the Aylan Kurdi images. I: Vis, F. \& Gouriunova, S. (red). The Iconic Image on Social Media: A Rapid Research Response to the Death of Aylan Kurdi. Visual Social Media Lab. http://visualsocialmedialab.org/projects/the-iconic-image-on-social-media

At mediene hadde betydning for engasjementet rundt flyktningsituasjonen bekreftes av en undersøkelse gjennomført av Fladmoe og kolleger (2016). Studien viser at antallet hjelpegrupper på Facebook skjøt i været etter oppstarten av Refugees Welcome to Norway 20. august, parallelt med en markant økning i medieoppslag som inneholdt "politiets utlendingenhet» eller «flyktning» $i$ august og september. 
risikerte livet for et trygt liv i Europa. En av lederne setter ord på en tilsynelatende generell tendens i intervjumaterialet, der RW-bevegelsen og lokalsamfunn som stiller opp for de nyankomne beskrives som en «varm bølge» i et ellers kjølig debattklima.

Jeg gikk hele sommeren og forsommeren og bare lurte på hvilket land jeg bodde i. Jeg lurte på hva som hadde skjedd med Norge, hvorfor det ble så kaldt og hatsk og...ondt. Du fikk liksom artikler og nyheter om at det var en lastebil i Østerrike [som smuglet flyktninger, forskers anm.] der så, så mange personer hadde blitt kvalt, og så er motsvaret [i kommentarfeltet] «Synd det ikke var flere». [...]. Du føler deg veldig alene når du ser kommentarfeltene. Og de som er imot [innvandring, forskers anm.] er veldig høylytte. De som er enige er litt stille. Så når jeg merka den der varme bølgen kom, så ble jeg sånn «Åh, jeg er ikke alene!» Da kjente jeg at da har jeg muligheten til å bidra, for jeg er ikke alene lenger.

Etter å ha følt seg hjelpeløse over lengre tid, fremhever flere lokale initiativtakere oppmerksomheten rundt Norway-gruppens arbeid på Tøyen i Oslo som en utløsende faktor.

Det her er en grasrotbevegelse som bare vokste ut av empati og behovet for å gjøre noe, etter å ha sittet i nesten et år og bare sett på unger som drukner og... ikke sant [...] Da de tok det der initiativet utenfor PU, så var det liksom sånn der... det var liksom legalt da, å bare dra i gang med noe, ikke sant.

Hendelsene i hovedstaden inspirerte denne lokallederen til å tenke at vanlige folk som henne hadde noe å bidra med, og at det bare var å «sette i gang» på eget initiativ, uten noen overordnede strukturer eller langsiktige planer på plass.

Som beskrevet innledningsvis, vektlegger teorier om sosiale bevegelser utviklingen av felles forståelsesrammer som en viktig forutsetning for mobilisering og engasjement. I RWs tilfelle fremstår informantenes opplevelse av å være del av en «varm bølge» av individer med samme verdier og holdninger til flyktningsituasjonen som dem selv, som en helt sentral faktor i oppstartsfasen. Selv om de alle startet opp selvstendig lokalt og hadde ulike motiver for å gå inn i arbeidet, gir de uttrykk for at de identifiserer seg med - og lar seg inspirere av - andre rundt om i landet og internasjonalt som ønsker å gjøre noe for flyktninger. Ved å finne sammen på 
sosiale medier ble også troen på at mobilisering i sivilsamfunnet kunne bedre situasjonen styrket. Denne overbevisningen fremstår som en viktig forutsetning for at informantene gikk inn i asyl- og flyktningfeltet i sine hjemkommuner, og insisterte på at de som en ny og uformell aktør kunne spille en avgjørende rolle - i en kontekst hvor de opplevde at myndighetene hadde begrenset kapasitet.

\section{Et overbelastet mottakssystem skaper rom for ny aktør}

I1: Du ser at systemet ikke fungerer når det kommer så mange

Samtidig som informantene satte i gang med å organisere klesinnsamlinger, begynte flere av de å trekke i sine nettverk og lokale krefter for å skaffe lagerlokaler, og komme i kontakt med mottak, myndigheter og lokalt forenings- og næringsliv slik at beredskapen var på plass når flyktningene etter hvert skulle ankomme sine hjemsteder. En utfordring for flere var at situasjonen i løpet av de første ukene og månedene var meget uoversiktlig. Ikke bare visste man lite om antallet flyktninger som ville komme; ofte visste ikke kommunen selv hvor neste mottak skulle etableres. Flere av informantene forteller om bruk av mer eller mindre utradisjonelle virkemidler den første perioden, og at terskelen var lav for å ta direkte kontakt med mottaksledere, lokalaviser eller ordførere for å få innpass på mottakene.

Enten det var utenfor PU på Tøyen eller i tilknytning til lokale mottak som ble opprettet rundt om i landet, beskriver samtlige informanter den første tiden av gruppenes eksistens som særlig intens. Flere omtaler arbeidet de første ukene og månedene som «førstelinjetjeneste» eller «nødhjelp». En av Oslo-informantene mener RW-frivillige var de første som 300-400 nyankomne møtte i Norge.

Det var ingen andre som strakk ut en hånd. $\mathrm{Da}$, i den akuttfasen der du på en måte kommer med...det kan være skader, det kan være sykdom, du kan ha traumer, du har ikke klær, du har ikke spist på gud vet hvor lenge...du har ikke vasket deg, du har ikke pusset tennene, du har unger som gråter, du har ikke bleier [...]. Det var jo snakk om førstelinjetjeneste i noen uker. 
Lederen for et av lokallagene beskriver hvordan hun la press på mottakslederen for å få lov til å komme tidlig i gang med levering av klær på et nyopprettet nødmottak. Samme kveld som hun og en gruppe RW-frivillige var på plass for å begynne å gjøre klar kleslageret - dagen før ventet ankomst - får de kontrabeskjed fra UDI: Det kommer 200 flyktninger om to timer.

Da står vi tjue frivillige, og de var seks ansatte, og bare sa... «sengene er jo ikke montert!» Og da var det omrokkering da, så av de tjue stod noen og lagde mat til de [flyktningene] kom, og noen begynte å skru senger. Og det ble jo suksesskriteriet. For det har ledelsen [på mottaket] sagt i ettertid; at de hadde jo ikke klart det. Hadde det ikke vært for at vi stod tjue stykker der [...].

Den samme informanten forteller videre at det på dette nødmottaket, der folk kom rett fra grensa, var fem hundre flyktninger innom i løpet av de første ti dagene - i lokaler med plass til to hundre personer av gangen. Også her, som på Tøyen, var det akutt behov for hygiene, klær og helsehjelp. Hun opprettet derfor en egen gruppe på Facebook for helsepersonell, der de koordinerte innsatsen slik at profesjonelle var tilgjengelig for å kunne vurdere helsetilstanden til beboerne på ulike mottak.

Informantene tegner et bilde av en akuttfase preget av til tider kaotiske tilstander, og der de selv opplevde å ha en helt sentral rolle i å dekke grunnleggende behov hos de nyankomne, i en situasjon der mottakssystemet syntes å være overbelastet. Men ifølge lederne i denne studien var det ikke bare det offentlige systemet som syntes å ha utfordringer med å respondere raskt: Selv om andre etablerte hjelpeorganisasjoner kom på banen etter hvert, opplevde flere av informantene at deres RW-gruppe var de første som var på plass de første dagene - i noen tilfeller var det snakk om uker. En lokalleder var overrasket over det hun oppfattet som et fravær av etablerte lokale frivillige aktører den første tiden.

[Organisasjon(er)] er vanvittig dyktige på å bistå flyktningene når de blir bosatt. Enerådende. Men de er ikke noe sånn...de har ikke vært inne i akuttfasen nå. Og det overrasker meg fullstendig at de ikke kunne vært mer «på» der. Men så tenker jeg at «Nei, men da er Refugees-bevegelsen der da!» 
En annen mener at mange organisasjoner er vant med å agere på oppfordring fra høyere hold, og at det som i flere tilfeller ble oppfattet som fravær skyldtes manglende informasjon og instrukser fra myndighetenes side til sivilsamfunnet. Et sentralt poeng hos samtlige informanter går likevel på evnen til å agere raskt. Flere setter spørsmålstegn ved om mange etablerte organisasjoner på feltet kan ha blitt for store og brede til at en kan snu seg raskt, og at det i en ekstraordinær situasjon som den som oppstod høsten 2015 var et særskilt behov for en mer uformell aktør som kunne «kaste seg rundt» etter hvert som ulike behov oppstod.

De [etablerte organisasjoner, forskers anm.] klarer ikke det der å snu seg så fort.

For jeg mener...jeg har stått nede på PU som beredskapsvakt og vært på utsida og delt ut klær. Og plutselig vært på togstasjonen og frakta flyktninger til PU også. Plutselig på et mottak. Altså, vi er der det er behov for der og da.

På den ene siden kan informantenes beskrivelser av RW-nettverkets rolle i akuttfasen belyse noen sentrale trekk ved det norske mottakssystemets- og etablerte organisasjoners handlingsevne i akutte situasjoner. Men uten en bredere studie der man inkluderer ulike typer aktører, både fra det tradisjonelle organisasjonslivet og fra myndighetssiden, er det vanskelig å gi et helhetlig bilde av de ulike rollene. Beskrivelsene lederne i RW gir kan også ses som en viktig del av en legitimeringsprosess, som en måte å fremheve sin egenart og betydning på. I sin studie av nordmenns bidrag i flyktningsituasjonen 2015/2016 finner likevel Fladmoe og kolleger (2016) at nyopprettede initiativer som RW var et viktig supplement til de etablerte frivillige organisasjonene. Mens de tradisjonelle særlig bidro med innsamling av penger, var de nyopprettede initiativenes arbeid i større grad knyttet til innsamling og utdeling av klær, mat og utstyr - nettopp den typen aktiviteter som blir beskrevet i denne studiens intervjuer.

Det var i den første akutte fasen at informantene opplevde at de virkelig fikk bevist hva de var «gode for». Flere forteller om en bratt læringskurve, og at det var gjennom rollen de spilte i ulike mottak og nærmiljøer at de fikk bevist seg selv og sin handlingskraft som ny aktør - og slik sett fikk fortsette sine aktiviteter etter at situasjonen hadde stabilisert seg, på lik linje med andre frivillige aktører. I lys av de tre dimensjonene som skisseres i kapitlets teoridel, er konteksten for framveksten av RW-nettverket - 
de politiske mulighetsstrukturene - kjennetegnet av et raskt tempo, harde meningsfronter og et overbelastet mottaks- og transittsystem. Et institusjonelt vakuum ga rom for en ny aktør. Særlig på nyopprettede mottak, der kapasiteten var presset og få rutiner på plass. Som vi så, deler også informantene følelsen av at de måtte gjøre noe for menneskene som kom, i mange tilfeller som en reaksjon på myndighetenes innvandringspolitikk og et «kjølig» debattklima.

Den omfattende mobiliseringen dreide seg imidlertid ikke bare om at de hadde et stort antall mennesker som ønsket å bidra, men at de med Facebook hadde de et gratis virkemiddel for å koordinere bidragene på en effektiv måte.

\section{Facebook som effektivt verktøy for organisering og mobilisering}

Et gjennomgående trekk i intervjumaterialet er at Facebook synes å ha vært helt sentral for de ulike gruppenes effektivitet og fleksibilitet, både under og etter oppstartsfasen, mye på grunn av mulighetene for fortløpende koordinering (såkalt sanntidskoordinering). Som vi har sett tidligere i kapitlet, var løsningen på utfordringer som oppstod, som samhandlingsutfordringer eller mangel på tolker og helsefolk, ofte at de «bare opprettet en ny gruppe» på Facebook ${ }^{11}$. Ved behov for å diskutere saker utenom de offentlige foraene, opprettes egne, lukkede chat-grupper. I mange av gruppene er det også journalister som kan plukke opp aktuelle nyhetssaker, og spre informasjon og nyheter fra gruppene.

Under intervjuene ble det tydelig at informantenes syn på sosiale mediers rolle varierte etter hva slags type arbeid deres RW-gruppe drev med. For Arctic-gruppen, der folk sitter spredt over hele landet, fremstilles Facebook som helt grunnleggende for å kunne utføre arbeidet de gjør. Ifølge en av informantene er det flere i Arctic som aldri har møtt hverandre «i levende live». Selv om enkelte har fungert som «bakkemannskap» i Nord-Norge, foregår det meste av deres arbeid på nett, der

11 Som f.eks. helsegruppper, tolkegrupper, landsadmin-gruppen, samt samarbeidsgrupper på Facebook for utveksling av mat og utstyr mellom lokalgrupper. 
de utveksler saker og søknader det kan være aktuelt å se på, diskuterer strategier for aksjoner og mediehenvendelser og svarer på spørsmål fra flyktninger. Også for lokalgruppene fremmes Facebook som selve fundamentet i organisering og administrering. En går så langt som å si at hennes lokalgruppe «er Facebook», fordi det meste av kommunikasjonen og koordineringen skjer der.

Vi er Facebook. Selvfølgelig, vi har jo hjemmeside der vi legger ut artikler og info til de som ikke er på Facebook da, vi har jo noen av de og, selv om det gjør det veldig vanskelig, for vi klarer ikke oppdatere den [hjemmesiden] like fort som vi oppdaterer Facebooken, for det går jo så mye kjappere! [...] Jeg tror Facebook er suksesskriteriet, det tror jeg det har vært. Og kommer til å være det [...] Det er her all kommunikasjonen skjer. Det er her folk møter hverandre.

I likhet med informanten over forteller flere av lokallederne om hvordan det aller meste av koordinering og informasjonsutveksling foregår på Facebook, i større eller mindre lukkede grupper. I utvalget er det ingen av gruppene som har egne, fysiske lokaler. En av informantene forteller om hvordan den lokale admin-gruppen har møtene sine på Facebook, der trådene i chat-gruppene fungerer som referat i etterkant.

Selv om Facebook utgjør et viktig organiseringsverktøy for informantene, tar de også hyppig i bruk mer tradisjonelle virkemidler som e-post og telefon. Flere fremhever betydningen av å møtes ansikt til ansikt, som på de ulike aktivitetene, eller ved at de rekrutterer nye frivillige ved å snakke om arbeidet de gjør til venner og bekjente. En informant forklarer at selv om mye av planleggingen, mobiliseringen og koordineringen for å få på plass aktiviteter skjer på Facebook og telefon, er det den «offline» handlingen som følger av online-aktivitetene som utgjør RWs gjennomslagskraft.

Altså, en ting er at vi har brukt Facebook, men det er jo fysiske mennesker som jobber i fysiske grupper [...] Det er ikke der [på sosiale medier] vi...vi «bor» ikke der. Vi bor på en måte i de tusen hjem og de tusen asylmottak, holdt jeg på å si [ler]. Man er jo overalt! Man sitter ikke liksom hjemme og skriver littegranne [...] Jeg kan ikke engang se for meg hvordan det skulle vært hvis vi ikke gjorde noen ting, at vi bare satt der med en datamaskin. Men det er instrumentet, ja. 


\section{Lavterskel frivillighet}

Noe av årsaken til at RW vekket stor oppmerksomhet, var at de evnet å mobilisere et stort antall frivillige på kort tid. Gruppenes omfattende bruk av Facebook fremheves av informantene som en sentral faktor til å senke terskelen for deltakelse, ved at de benytter en plattform de fleste nordmenn bruker til daglig til å spre muligheten til å bidra, og der de fortløpende kan kommunisere helt konkrete behov. Flere forteller at de opplevde at andre, som dem selv, lenge hadde ønsket å bidra med noe etter å ha fulgt flyktningsituasjonen i media over tid. Med Facebook som hovedverktøy bidro Refugees-initiativet til å senke terskelen for å engasjere seg frivillig på flere måter.

Lett tilgjengelig informasjon via Facebook-plattformen og hjemmesiden førte ifølge en informant til at det bare «ramla inn» mennesker som ønsket å bidra på forskjellige måter. Hun beskriver hvordan det blant de frivillige er både etniske nordmenn, tidligere flyktninger, og nyankomne som selv bor på mottakene - og som kan bidra med kartlegging av behov, tolkehjelp osv.

[...] Det som har vært så fantastisk den høsten her, og med det prosjektet som Refugees er da, er at det bare har ramla inn den ene ressursen etter den andre.

Og plutselig så hadde vi jo en flerspråklig gruppe som drev og oversatte til alle språkene vi trengte, ikke sant. Så fikk vi internettsiden som stod på engelsk også ganske kjapt...så har vi hatt ressurser som bare har tenkt at «yes, dette har jeg lyst til å bidra til!».

Ikke bare var informasjonen lett tilgjengelig: Flere av lederne forteller om hvordan mange av deres frivillige først hadde vært i kontakt med etablerte organisasjoner, men opplevd å ikke få svar på henvendelsen på grunn av den store pågangen. Så selv om RW gjennom både nettsider og Facebook-sider henviste folk til andre organisasjoner, var det mange som ønsket å bidra gjennom aktivitetene som RW selv stod for ${ }^{12}$. Flere mener evnen til å kunne respondere raskt på folks ønsker om å bidra var avgjørende for det store engasjementet og innsatsen.

12 De to er ikke gjensidig utelukkende: Flere RW-frivillige er også aktive i andre organisasjoner på asyl- og flyktningfeltet (se Fladmoe mfl., 2016). 
En generell tendens i intervjumaterialet er ledernes beskrivelser av frivillige som ønsket å bidra uten å måtte binde seg til en spesifikk organisasjon eller gå på kurs. Selv om de respekterer at enkelte mottak, og spesielt de som har sårbare grupper som barn og enslige mindreårige, krever kontrakter og politiattester, mener flere av informantene at det ikke alltid bør være nødvendig med lange kurs for å få lov til å bidra frivillig på mottak ${ }^{13}$. Særlig ikke i en situasjon med akutt behov for frivillige hender, og å dekke grunnleggende behov som sortering og utdeling av klær og utstyr. Flere av informantene hevder at nøkkelen til den store mobiliseringen også handler om den lave graden av organisering og formelle strukturer, og særlig at folk får bidra med det de selv ønsker og føler de er gode til. Ved å ikke kreve at folk må binde seg, og en tanke om at «alle monner drar», opplever flere av lederne at de får benyttet seg av alle som vil bidra - også innsatsen til de som kun kan bidra av og til, og som andre som stiller strengere krav, kanskje mister.

[...] Det er den her lavterskelbiten jeg er så prinsippfast på, fordi at ja, har noen lyst til å jobbe 80 timer på en uke: vær så god! Har noen lyst til å jobbe én time hvert halvår: helt greit. For til sammen så får vi det til. [...] Jeg pleier å signere med det på innleggene mine og jeg, med at «sammen utgjør vi en stor forskjell». Det er liksom sånn....noen er litt sånn: «jeg får gjort så lite». Nei, du gjør ikke det, for det er litt sånn [...] det er et puslespill: Noen er en stor brikke og noen er en liten brikke. Bildet blir ikke ferdig hvis ikke alle brikkene er på plass.

Vi vet fra tidligere studier at en sentral barriere for frivillig deltakelse er at folk ikke vet hvor de skal starte, eller ikke har blitt spurt (Wollebæk mfl., 2015). Ved å fremme konkrete behov via en uformell kanal som Facebook - som de fleste benytter daglig - er informasjonen om hvordan man kan bidra mer tilgjengelig enn den ellers ville vært. Med budskapet om at alle kan bidra - når de kan, og gjerne med utgangspunkt i hva de selv opplever de har kapasitet og interesse for - peker informantene på helt sentrale kjennetegn ved det som i bokens innledningsdel blir omtalt som en moderne og mer «refleksiv» form for frivillighet, kjennetegnet av mer

13 En av de lokale RW-gruppene hadde på intervjutidspunktet opprettet et eget introkurs for frivillige. 
individuelle motiver, og der aktiviteten står i sentrum, uten at man må binde seg til en spesifikk organisasjon over tid (Hustinx \& Lammertyn, 2003; Wollebæk mfl., 2015).

Informantene beskriver et handlingsnettverk som i den første tiden er preget av lite byråkrati, flate strukturer og sanntidskoordinering som gjorde dem fleksible og effektive i en ekstraordinær situasjon. Med Facebook som plattform har RW en svært effektiv mobiliseringsstruktur som muliggjør rask, omfattende og kostnadsfri koordinering og informasjonsspredning, samtidig som den uformelle formen - med fravær av krav og byråkrati - bidrar til å senke terskelen for frivillighet. På denne måten er RW et godt eksempel på det Bennet og Segerberg (2012) betegner som en konnektiv handlingslogikk, der ny kommunikasjonsteknologi bidrar til å kutte tidkrevende og kostbare ledd, samtidig som toveiskommunikasjonen på Facebook gjør det mulig å tilrettelegge for å fortløpende møte både frivilliges ønsker om å bidra og mottakeres behov.

Den uformelle, flate nettverksformen som trekkes frem som gruppenes styrke og oppskriften på suksess i akuttfasen, skulle likevel raskt vise seg å by på utfordringer - både fordi nettverket vokste raskt, og i møte med andre aktører på feltet. Som en av informantene uttalte: «Vi satte jo i gang før vi hadde organisert oss».

\section{Organisering og utvikling}

Mens vi hittil i analysen har fokusert på etableringsfasen til gruppene i utvalget, skal vi i det følgende rette oppmerksomheten mot utviklingen etter den første spontane organiseringen. Etter kort tid oppstod det spenninger mellom nettverksorganisering på den ene siden og behovet for kontroll og demokratiske strukturer på den andre. En utvikling drevet dels av et internt behov for kontroll og oversikt, og dels av eksterne krav og forventninger knyttet til de politiske mulighetsstrukturene. Særlig i møte med andre aktører har informantene gjort seg erfaringer som tydeliggjør og utfordrer RWs særtrekk og forståelsesrammer, og som ligger til grunn for en videre refleksjon rundt gruppenes fremtid: Hvor formalisert er det mulig å bli uten å miste seg selv? 


\section{Norway-gruppen: Fra lokalgruppe til paraplyorganisasjon}

Etter hvert som lokale grupper ble opprettet over hele landet, var Norway-gruppen i en periode preget av det en av informantene betegner som «voksesmerter». Mens RWTN startet opp som et samlingssted for alle som ville bidra for flyktninger, forsvant mye av den koordinerende aktiviteten i løpet av kort tid ut til lokalgruppene. En av Oslo-informantene forteller om situasjonen som oppstod etter at frivillige fra Norway-gruppen opprettet Refugees Welcome to Oslo, og med det overtok mye av den koordineringsfunksjonen Norway-gruppen opprinnelig hadde hatt på Tøyen.

Hele dette prosjektet startet jo opp som Refugees Welcome to Norway, men det burde vært startet opp som Refugees Welcome to Oslo. For [aktiviteten i Norway-gruppen, forskers anm.] var jo bare rundt i Oslo. Så når disse lokale gruppene begynte å poppe opp, så brøt jo Oslo ut og dannet Refugees Welcome to Oslo, samtidig som Østfold, Vestfold...ikke sant. Så da var det sånn at da hadde liksom.... Norway hadde liksom ikke noen sånn funksjon sånn sett, fordi Norway hadde vært på Tøyen, ikke sant.

Det faktum at «hvem som helst» kunne opprette en RW-gruppe på Facebook, førte raskt til at man mistet kontrollen over hva som fantes av RW-initiativer rundt om i landet ${ }^{14}$. En annen forteller om hvordan det var lite samhandling mellom lokale initiativtakere når det kom til opprettelsen av nye grupper.

Det har liksom ikke vært sånn avtalt at «OK, nå først oppretter vi en lokalgruppe, og så en fylkesgruppe, for det passer bra» og sånn og sånn. Det har på en måte vært sånn at «bæm», der var det noen som startet der. «Bæm», der var det noen som startet der. Også kanskje man snakket sammen littegranne [...].

En av Oslo-informantene forteller om hvordan et stadig mer uoversiktlig landskap av lukkede lokalgrupper fikk RWTN til å tenke nytt om sin funksjon. En av de sentrale aktørene satte seg ned og forsøkte å få en oversikt over alt som skjedde rundt om i landet. For å bevare en viss

14 Jmf. Fladmoe mfl. (2016) som finner langt flere RW-grupper på nett enn det som registrert hos RWTNs hjemmesider. 
grad av oversikt og informasjonsflyt opprettet hun en lukket «landsadmin»-gruppe på Facebook, der hun samlet lokale ledere og administratorer. Her kunne de utveksle erfaringer og informasjon, samt melde fra om lokale nyheter som kunne deles på Norway-gruppen. Fra å ha hatt en sentral rolle i koordineringen av lokale aktiviteter i Oslo, var Norway-gruppa nå på «et nivå over», der de satt med oversikten og kunne kanalisere bidragene inn i lokalgruppene.

Fremveksten av lokale grupper var en ønsket utvikling, «målet var jo at folk skulle gjøre det som trengs», som en informant forklarer. Men den løse og desentraliserte strukturen førte til et behov for koordinering og erfaringsutveksling, da flere lokale administratorer hadde spørsmål om logobruk, organisering og praktiske utfordringer i forbindelse med oppstarten. Som Shirky (2008) argumenterer for, fungerer ad hocorganisering så lenge det er snakk om få aktører og et par aktiviteter, men når et initiativ begynner å øke i omfang, vokser styringsutfordringene gjerne raskere enn organisasjonens eller nettverkets størrelse. Ifølge en av informantene fungerte Norway-gruppen nå som en paraplyorganisasjon og infogruppe for lokalgruppene, med et mål om å få de lokale gruppene opp og stå som selvstendige enheter.

\section{Utfordringer i formaliseringsprosessen}

Veien fra en løsere form mot en ny struktur og funksjon skulle imidlertid vise seg å ikke være uten utfordringer. Parallelt med at koordineringen av aktiviteter i stor grad gikk ut i lokalgruppene, meldte behovet seg for å få på plass noen mer formelle rammer i Norway-gruppen. Etter at de i starten hadde mottatt mindre beløp på en privat konto til innkjøp av mat og utstyr til de nyankomne, forteller en at det i takt med oppmerksomheten rundt initiativet begynte å komme inn større beløp på «tusenvis av kroner» fra firmaer og privatpersoner som ønsket å bidra. Ifølge en av Osloinformantene var det «rett og slett for å følge retningslinjene for norsk lov» at Norway-gruppen ble registrert som organisasjon i Brønnøysundregisteret 30. august 2016, som den første av RW-gruppene i Norge.

Selv om alle var enige om behovet for å få på plass rammene rundt det økonomiske, fulgte utfordringene av det som følger av at man registrerer 
seg som en frivillig organisasjon; nemlig at man må ha et styre, som igjen fordrer demokratiske strukturer ${ }^{15}$. På intervjutidspunktet hadde Norway-gruppen et midlertidig («interim») styre som skulle fungere inntil de fikk på plass de nødvendige strukturene for å gjennomføre et demokratisk valg av styremedlemmer. Ifølge flere av informantene førte nedsettelsen av interrimstyret til det de beskriver som en intern konflikt som utspilte seg på «åpen Facebook-vegg» på den nasjonale gruppens profil. Rundene førte til at enkelte av ildsjelene som hadde vært med å starte opp initiativet falt fra, og at en del følgere og lokale ledere i utvalget meldte seg ut av Norway-gruppen - om ikke permanent så til «den verste stormen hadde lagt seg» etter noen uker.

Etter at RW-gruppene hadde gjort seg noen nyttige erfaringer gjennom den første, spontane mobiliseringen, opplevdes arbeidet med å få på plass en viss grad av struktur og kontroll som en naturlig neste fase. Til tross for at det førte til noen «voksesmerter», med diskusjoner om hva RW skulle være i en norsk kontekst, og hvordan de skulle organiseres, ble prosessen av flere oppfattet som helt nødvendig for å kunne fortsette med arbeidet over tid. Flere av informantene understreker hvordan det er viktig å anerkjenne de interne aktørenes betydning for utviklingen, blant annet hvordan uredde aktivister må til for å starte opp noe, men at det er andre egenskaper som trengs for at et initiativ som RW skal overleve over tid.

Det har hele tiden vært en håndfull personer som har sørget for at dette her på en måte har gått mer og mer mot å bli en formell organisasjon med de riktige rammene og ikke på en måte bare er forblitt en sånn flat struktur som bare lever sitt liv, men som på en måte har en litt sånn ambisjon om å bli organisert...eller hva man kan si da, en «ordentlig» administrativ enhet som skal sørge for at man har bærekraft i engasjementet da. For det er ikke noen selvfølge.

For denne informanten handler et viktig steg mot det hun omtaler som en mer «profesjonell organisering» om å bevege seg over på andre plattformer enn sosiale medier. En av Oslo-informantene forklarer hvordan

15 Forstått som vedtekter og formelle rammer for interne valgprosesser og hvem som skal kunne stemme ved disse. Se krav for registrering i Brønnøysundregistrene/frivillighetsregisteret:https://www.brreg.no/lag-og-foreninger/registrering-i-frivillighetsregisteret/ 
Norway-gruppas bevegelse bort fra Facebook har fulgt naturlig av arbeidsdelingen mellom gruppene. Ettersom lokalgruppene i stor grad overtok koordineringen av lokale aktiviteter, ble ikke Facebook-gruppen et like viktig organiseringsverktøy for RWTN. På intervjutidspunktet benyttet den nasjonale gruppen i hovedsak plattformen for å dele informasjon og aktuelle nyhetssaker, som en «hvilken som helst annen Facebook-gruppe».

Altså... misforståelsen her da... er for det første at Refugees Welcome to Norway er en Facebook-gruppe. Fordi at den veldig fort ble en organisasjon. Også ble det et skille mellom gruppe og organisasjon. En stor misforståelse er det at vi administrerer og organiserer oss gjennom den Facebook-gruppen. Det er ikke tilfellet. Fordi veldig fort ble alt engasjementet spredt til lokale grupper [...] Det [Facebook] er bare en måte å organisere seg på lokalt. Det er på en måte... etter hvert så har vi jo begynt å bruke telefon og e-post og fysiske møter selvfølgelig, sånne ting...som seg hør og bør.

På mange måter beskrives utviklingen av Norway-gruppen som en tung, men nødvendig prosess. Fra den nasjonale gruppens perspektiv oppstod raskt et behov for en viss grad av kontroll og demokratiske strukturer, både av rent praktiske og lovmessige hensyn, som at man ikke kunne ha penger på privat konto, og at man trenger et organisasjonsnummer for å søke om midler.

\section{Selvstendige lokalgrupper}

Den lokale autonomien fremstilles av de lokale lederne som helt avgjørende for gruppenes virke, både for deres identitet og for å kunne arbeide mest mulig effektivt. Selv om de ulike gruppene er sammenkoblet i navn og på nett, har de ingen formell kobling til Norway-gruppen. Derfor reagerte også enkelte da Norway-gruppen påtok seg en mer overordnet funksjon, og "plutselig skulle representere dem». En informant understreker hvordan lokallagene på ingen måte må anses som «undergrupper»av RWTN, og hvorfor det er så viktig at det forblir slik.

Jeg tror det [har å gjøre med at] ingen har lyst til å bli fortalt hva de skal gjøre.

Det er liksom...hver gruppe er litt sånn...ikke som kongen på haugen, for vi er ikke der heller. Men det er noe med at det er sånn vår gruppe fungerer, og 
Oslo-gruppen jobber på en helt annen måte, og Kongsberg-gruppen jobber på den måten. Det er ingen fasit på hvordan gruppene fungerer, og da funker det dårlig når noen prøver å trykke ned noe [ovenfra, forskers anm.], for det er litt sånn... «jammen det passer kanskje for den gruppen nedi Hedmark, men det passer ikke for vår gruppe her».

Mens sosiale mediers rolle synes å ha endret seg for den nasjonale gruppen, fremstår Facebook som det mest sentrale organiseringsverktøyet for lokalgruppene, som en plattform for både internkommunikasjon og for å mobilisere til og koordinere offline aktiviteter.

I forbindelse med at Norway-gruppen formaliserte seg, var det også flere av de lokale lagene som gjorde det samme ${ }^{16}$. For to av informantene hadde de interne stridighetene og usikkerheten rundt hva som ville skje med Norway-gruppen en viss betydning for at de ønsket å formalisere seg for å stå på egne ben. Men for de fleste handlet det som i Oslo først og fremst om økonomiske hensyn, og at de i tillegg til klær og utstyr hadde fått inn pengedonasjoner som ikke kunne stå på privat konto over lengre tid. Et annet viktig aspekt flere trakk frem, var hvordan det å ha et organisasjons- og kontonummer er en nødvendig forutsetning for å etter hvert kunne søke om midler som kan støtte opp om mer langsiktige prosjekter. Mens prosessene med å få på plass et interim-styre Norwaygruppen bød på utfordringer, fremstod det mindre konfliktfylt å få på plass midlertidige styrer i lokalgruppene. For de fleste dreide det seg om at ildsjelene som allerede var mest involvert $\mathrm{i}$ administrative oppgaver, fikk mer formaliserte roller som styremedlemmer. Men som vi skal se under «Veien videre», skulle det å få på plass et demokratisk valg vise seg å være en utfordring for flere.

Formaliseringen av RW-gruppene handlet imidlertid ikke bare om praktiske og økonomiske hensyn, det hadde også en mer normativ dimensjon som dreier seg om legitimitet og det å bli tatt mer på alvor som en ny aktør på feltet.

\footnotetext{
16 Det er imidlertid viktig å bemerke at dette kun gjelder 12 av RW-gruppene totalt, men et flertall av gruppene i denne studiens utvalg. Flertallet av de registrerte lokale RW-gruppene har altså ikke registrert seg som frivillige organisasjoner.
} 


\section{«lkke bare en Facebook-gruppe»: RW i møte med andre aktører}

Ifølge Seippel (2003), kan ikke utviklingen av organisasjoner og sosiale bevegelser forstås uavhengig av den større konteksten de går inn i. Dette innebærer også å se dem som del av et nettverk av ulike aktører. Som vi så ovenfor, var samarbeid med andre aktører, som kommunen, mottaksledere, og private aktører for donasjoner og lokaler, helt sentralt for RW-gruppenes arbeid og gjennomslagskraft både i oppstartsfasen og også etter at den akutte situasjonen hadde roet seg.

Et flertall av informantene forteller om gode samarbeidsrelasjoner, særlig til lokale frivillighetssentraler og mottaksledelse, og det er en gjennomgående tendens at de ønsker å samarbeide med alle som jobber for å bedre situasjonen for de nyankomne. Men kommunikasjonen med etablerte organisasjoner har ikke bestandig gått like lett. Selv om de opplever å ha spilt en viktig rolle i akuttfasen, opplevde noen at enkelte lokale frivillige aktører var skeptiske til dem i begynnelsen.

Jeg hadde jo en konflikt med [etablert lokal organisasjon] på mottaket, for jeg ringte de og sa «kan dere ikke sende helsefolk, noen førstehjelpsskrin... whatever?» Og da var svaret jo selvfølgelig «Dette skal ikke dere blande dere opp i, for dere er jo bare en Facebook-gruppe». Det er jo et sånt argument vi møtes med [...] Vi er en «døgnflue», også er vi «bare en Facebook-gruppe». Og jeg tenkte bare... whatever. Vi får gjort mye! Så bare kall oss det, bare undervurder oss. Jeg tror vi får gjort mer enn dere [lokal organisajon] likevel» [...].

Informanten forteller at hun opplevde at samarbeidet ble bedre etter hvert som mottaksledelsen fikk koordinert de frivillige aktørenes rolle på mottaket, slik at de ikke følte at de «tråkket hverandre på tærne». Hun forteller videre om hvordan de opplevde å få mer legitimitet etter at de mer etablerte aktørene så hva RW-gruppen fikk utrettet på det første akuttmottaket de var inne på, i tillegg til at de etter relativt kort tid registrerte seg som organisasjon, og opprettet et midlertidig styre.

[...] For meg er det den biten at vi blir tatt hakket mer seriøst, de kan ikke kalle oss en Facebook-gruppe lenger. Vi er faktisk organisert, vi er en organisasjon. 
Til tross for frustrasjonen over å ikke bli tatt på alvor av etablerte organisasjoner og instanser, reflekterer en av informantene over hva som kan gjøre det utfordrende og uvant å forholde seg til en ny og uformell aktør.

Vi har jo på en måte ikke noe sånn der A4-opplegg med noen slags veldig sånne formelle og riktige nøkkelpersoner liksom. Altså sånt. Det er...det er ukomfortabelt å forholde seg til en sånn ad hoc-gruppe, da. [...] De ser sikkert for seg at det er vanskelig å forplikte oss, eller ha en god dialog som løper over lengre tid og sånne ting $[\ldots]$.

En annen mener at noe av årsaken til at hennes RW-gruppe har hatt utfordringer med å få på plass lokale samarbeid handler om at det for mange andre aktører er ressurskrevende å bygge nettverk, fordi det forventes at en må møtes ansikt til ansikt («De jobber ikke på nett på samme måte som vi gjør»). Med beskrivelsene av ulike måter å arbeide på er informantene her igjen inne på det Bennet og Segerberg (2012) betegner som ulike «logikker», og forskjellen mellom det de omtaler som mer tradisjonelle former for kollektiv handling og en konnektiv handlingslogikk. Den sistnevnte synes i særlig grad å kjennetegne RWnettverket, der ny kommunikasjonsteknologi som Facebook spiller en såpass sentral rolle i organisering og kommunikasjon både internt og eksternt. Ikke bare kan RW sies å følge en annen handlingslogikk, de utfordrer også med sin ubyråkratiske og mer uformelle organisering rådende forståelser av hva som kjennetegner en legitim aktør på feltet. Videre skal vi se hvordan en av de sentrale utfordringene for RWgruppene fremover handler om å finne en balanse mellom egne behov og ytre forventninger om å få på plass noen formelle rammer på den ene siden - og slik sett bli «likere» mer etablerte aktører - og å opprettholde det opplever som deres grunnleggende identitet og særpreg som en uformell grasrotorganisasjon på den andre.

\section{Veien videre: Fra nettverk til hierarki?}

Et gjennomgående trekk ved gruppene i utvalget er at de alle er preget av lav grad av hierarki og byråkrati. Mens Arctic-nettverket ikke har noen 
utpekt leder, og kan sies å ha en mer desentralisert struktur som følge av at de ikke har noen lokal «kjerne», har Norway og de andre lokalgruppene som har registrert seg som formelle organisasjoner til en viss grad fått en mer hierarkisk form, med et styre og en styreleder øverst, etterfulgt av administratorer og frivilligkoordinatorer, og frivillige nederst ${ }^{17}$. Flere av informantene er imidlertid ikke komfortable med «leder»-tittelen. Da de under intervjuet ble spurt om å tegne et organisasjonskart, var det for flere ikke naturlig å sette opp en tradisjonell struktur med piler som gikk opp og ned mellom nivåer (som viser rapporteringsveier og maktrelasjoner). En mener det er få av RW-gruppene som vil bli satt i en «bås» som en viss type organisasjon. En annen forteller at hun tenker på styret som en «ren praktikalitet», og at de liker å tenke at aktørene står «ved siden av hverandre», snarere enn under hverandre i en hierarkisk form. Men de har likevel en struktur, riktignok med færre nivåer sammenlignet med mange andre organisasjoner.

Vi har jo...ikke sant...vi har styreleder og styre. Og under styret så har vi frivilligkoordinatorene, som koordinerer de ulike aktivitetene. Og under der igjen så er det bare en kjempesvær masse med frivillige [som består av] en liten masse som er de aktive frivillige, og under der igjen så har du liksom alle støttespillerne, tilhengerne....hva du kan kalle de på Facebook.

Et sentralt poeng hos flere er at det er lett å komme seg inn i ansvarsroller dersom en ønsker det.

Flere av informantene mener de flate strukturene bidrar til å gi RW-gruppene en fleksibilitet og effektivitet som skiller dem fra mer etablerte aktører på feltet, hvor beslutninger gjerne må gjennom mange møter og ledd før de kan vedtas og gjennomføres. En av lederne, som har bakgrunn fra prosjektledelse i større organisasjoner og bedrifter, mener det er likheter i måten å jobbe på, men at man i RW-gruppen får gjort ting fortere. Fordi ting ikke må gjennom «høringer og sånne ting», mener hun at det bare tar «minutter» fra de har bestemt seg for noe til det er gjennomført.

17 I grupper som ikke har formalisert seg, har en færre ledd. De fleste gruppene har imidlertid én person som fungerer som leder og fremstår som deres ansikt utad. 
$\AA$ minimere antall møter og byråkratiske prosesser synes som en helt sentral strategi for mange av lederne, og en form de bevisst søker å beholde fremover - uavhengig av om de er formelle eller ikke. En mener også at det med få ledd gjør det enklere å reagere raskt, og offentlig, på hendelser som i andre organisasjoner vil måtte diskuteres og avklares på mange nivåer.

Et annet særtrekk som løftes frem av flere informanter, er tilpasningsdyktigheten som følger av en fleksibel struktur. Ved at de tar utgangspunkt i de lokale behovene, kan de tilpasse aktiviteter etter behovene som til enhver til måtte melde seg («bottom-up»), fremfor en mer toppstyrt tilnærming som enkelte mener kan prege andre etablerte lokale aktører - som kan tendere til å «gjøre ting som de alltid har gjort det». Denne ad hoc-evnen fremheves av informantene som en av de største forskjellene mellom RW og andre aktører.

\section{Utfordringer: Demokratiske strukturer, økonomi og frykt for å brenne ut ildsjelene}

Selv om de ser mange muligheter ved å beholde en løsere nettverksform, reflekterer informantene også rundt hvilke utfordringer de står overfor fremover. For det første dreier det seg om demokratiske utfordringer. Som vi så tidligere har de fleste fått på plass midlertidige styrer, men flere slet på intervjutidspunktet med å få på plass demokratiske strukturer. Særlig når de som var ansvarlige for å få på plass disse var de samme menneskene som var fullt opptatt med den daglige jobben det innebar å koordinere en gruppe. En sentral utfordring handler om gjennomføring av et demokratisk valg, og hvem som skal kunne stemme, når det ikke er avgrenset hvem som er medlem og ikke, som i en medlemsorganisasjon. Flere så for seg å avgrense stemmeretten til personer som stod oppført som frivillige på gruppenes ulike aktiviteter. For Norway-gruppen dreide det seg om å finne ut av hvem som skulle stemme i de ulike lokalgruppene, og hvordan stemmene eventuelt skulle fordeles ut fra gruppenes størrelse.

En annen utfordring som går igjen blant gruppene i utvalget handler om økonomi og langsiktighet. Selv om det etter akuttfasen roet seg for 
mange, er det flere som mener man kan «drive på knapper og glansbilder en stund», men at det blir vanskelig i lengden. For flere av informantene fremstår det å kunne få et varig og sentralt lokale hvor de kan møtes og drive aktiviteter, samt å få midler til å kunne betale noen ansatte, som viktig for å kunne fortsette arbeidet fremover.

Målet er jo at det kan bli det [en organisasjon med ansatte], uten at det blir så voldsomt byråkratisk og administrativt, men på en måte at det er noen som har ansvar som de får lønn for. Sånn at de får...altså, jeg tror liksom det er verdt å investere litt i det engasjementet her da, sånn at det blir langsiktig.

En av informantene er imidlertid bekymret for at man blir for fokusert på penger og prosjektsøknader ved å formalisere seg. Ikke bare vil de da bli nødt til å følge retningslinjene og rapporteringskravene som følger av tilskuddene, hun frykter også at lokalgruppen skal miste av syne hvorfor de begynte med arbeidet i utgangspunktet, som ikke dreide seg om penger, men om å «klare seg på overskuddet folk har liggende hjemme».

I tillegg til de økonomiske faktorene, og manges ønske om mer forutsigbarhet, er det også et tredje kjennetegn ved en mer uformell organisering som fremstår som en utfordring fremover, nemlig det som er knyttet til å ivareta enkeltindivider som legger ned mye tid og energi i arbeidet. Selv om det å organisere seg via sosiale medier på mange måter senker de økonomiske kostnadene ved kollektiv handling, så fører det å operere utenfor «rammene» over tid til en annen type kostnad, som for alle gruppene handler om at ildsjelene og kjernefrivillige sliter seg ut. En informant forteller om hvordan de i «perioder har brent lys ikke bare i begge ender, men i midten, og bare gått på». Andre forteller historier om hvordan de i perioder har stått på «døgnet rundt», fordi det hele tiden «rant inn med meldinger og forespørsler på chatten». En uformell struktur medfører altså at mange av RW-gruppene er helt avhengige av enkeltpersoners frivillige engasjement for den daglige drift og virke. På denne måten fremstår de som mer sårbare, uten den samme forutsigbarheten og støtteapparatet som mer formaliserte organisasjoner kan tilby sine ansatte. 
Til tross for at enkeltgrupper kan oppleves som sårbare, beskrives nettverket av relasjoner av informantene som robust og levedyktig over tid. En av informantene snakker om hvordan en lokal RW-gruppe hun var med i hadde gått «i dvale». Hun forklarer videre hvorfor hun ikke vil bruke begrepet «død», fordi nettverket og kontaktene alltid vil være der - og dermed vil kunne mobiliseres hvis noe lignende skulle skje igjen. En annen sammenligner nettverket med sopper som «popper opp» der det trengs. Styrken ligger nettopp i at de lett kan gå over i andre funksjoner alt etter hva det måtte være behov for det, «og så må det ikke behandles i et nasjonalt styre og nye vedtekter og sånne ting [...]». Så selv om det for Norway-gruppen er et poeng å bli mer profesjonell for å kunne opprette langsiktige samarbeid opp mot myndighetsnivå, er det for lokallagene fleksibiliteten og det mer uformelle som synes som nøkkelen også for det videre arbeidet. En av lokallederne oppsummerer sine visjoner for RWs fremtid slik:

Mitt mål er at vi fremdeles skal være litt den der uordentlige aksjonsgruppa, grasrotbevegelsen, som ikke er for «ordentlig» og som ikke har møter på samme måte [som andre organisasjoner]. Vi har Facebook og SMS hvis det ikke funker på Facebook. Og så møtes vi innimellom [...] Vi skal ikke være formelle, og vi skal bare møte opp. Så kan de andre komme etter at de er ferdige på møtene sine [...] Og de er veldig velkomne etter.

\section{Oppsummering og diskusjon}

Med utgangspunkt i erfaringene til ledere og nøkkelpersoner i et utvalg initiativer rundt om i landet har kapitlet fokusert på fremveksten og utviklingen av Refugees Welcome-nettverket i Norge. Studien anlegger et perspektiv der RW studeres som en sosial bevegelse, der både politiske mulighetsstrukturer, mobiliseringsstrukturer og rådende forståelsesrammer - og samspillet mellom disse - påvirket gruppenes etablering, vekst og virke.

Funnene peker i første omgang på hvordan de tre dimensjonene kan bidra til å forklare RW-initiativenes fremvekst og gjennomslagskraft. Det offentlige mottaksapparatet var overbelastet, og behovet for frivillige 
bidrag stort (mulighetsstruktur). På flere måter kan det se ut til å ha oppstått et «institusjonelt vakuum» i akuttfasen, som beredte rom for en ny og uformell aktør. Facebook fungerte som et svært effektivt verktøy for å informere, mobilisere og koordinere lokale aktiviteter og frivillig innsats (mobiliseringsstruktur). Den uformelle organiseringsformen, med mindre formaliteter og bindingskrav - som ga mulighet for at frivillige kunne bidra med utgangspunkt i egne ressurser og kapasitet - bidro til å senke terskelen for deltakelse.

Videre ser vi at det etter kort tid oppstod en spenning mellom en flat og uformell organisering på den ene siden, og behov for formalisering og styring på den andre. Ikke bare var utviklingen drevet av et internt behov for kontroll og oversikt. Også eksterne behov, krav og forventninger skapte grobunn for at flere av gruppene raskt ble formelle organisasjoner. Dette innebar også en mer normativ dimensjon knyttet til legitimitet, og forutsetninger for å bli tatt på alvor som en seriøs aktør som kan inngå i samarbeid med etablerte aktører på asyl- og flyktningfeltet (forståelsesrammer).

Analysene tydeliggjør hvordan en flerdimensjonal tilnærming kan være en fruktbar inngang til å studere institusjonalisering, og hvordan de ulike dimensjonene kan spille ulik rolle på ulike stadier i institusjonaliseringsprosessen (Seippel, 2003). For eksempel la de politiske mulighetsstrukturene til rette for at flere av RW-gruppene kunne spille en sentral rolle i beredskapen i sine lokalsamfunn, før mulighetsrommet igjen «tettet» seg etterhvert som andre etablerte aktører kom på banen og situasjonen roet seg. Som vi så, var det først etter den første intense perioden at behovet for legitimering meldte seg, og at erfaringer gjort $\mathrm{i}$ møter med andre aktører på feltet nedfelte seg i en tydelig identitet og organisasjonsstruktur («hvem og hva er vi?») - et særpreg som særlig ligger i en uformell, effektiv og fleksibel organisasjonsform muliggjort av Facebook-plattformen. Funnene tydeliggjør også hvordan digitaliseringens potensiale (mobiliseringsstrukturene) betinges til dels av det politiske mulighetsrommet (hvilken plass kan hvilke organisasjonstyper få?), og dels av forståelsesrammene (forventninger til hva en legitim aktør på feltet er og bør være). 


\section{Kommunikasjonsteknologi gir nye muligheter, men innenfor visse rammer}

Informantenes refleksjoner rundt hvor formaliserte gruppene kan bli uten å miste seg selv gir videre grunnlag for en bredere diskusjon rundt hva RW-casen kan si om nye former for frivillighet generelt, og om bærekraften i denne typen løse, digitale nettverk spesielt. På flere måter kan RW sies å representere en ny organiseringsform som skiller seg fra mer tradisjonelle former for kollektiv handling, først og fremst fordi bruken av Facebook som organiseringsverktøy fremstår som en betingelse for gruppenes effektivitet og gjennomslagskraft. På individnivå synes det som om RW med bruken av sosiale medier som et uformelt verktøy for informasjonsspredning og mobilisering har funnet en måte å appellere til det som omtales som stadig mer «refleksive» frivillige på, som er mer opptatt av enkeltsaker, er løsere bundet til organisasjoner og har større forventninger til å realisere seg selv gjennom det frivillige arbeidet. Sosiale mediers åpenhet og mangel på krav og medlemskap, kombinert med muligheten til å fortløpende oppdatere konkrete behov og reagere raskt på ønsker om å bidra (på frivilliges egne premisser), synes å ha gjort det mulig å benytte seg av engasjementet som oppstod i forbindelse med en akutt situasjon.

Selv om mange frivillige organisasjoner i dag er online, med bruk av både hjemmesider og sosiale medier, har tidligere studier vist at frivillige organisasjoner i liten grad tar i bruk de interaktive mulighetene internett tilbyr (Eimhjellen mfl., 2013). Ikke nødvendigvis fordi det er mangel på vilje, men fordi det på mange måter kan være utfordrende å skape interaktivitet samtidig som man evner å beholde en viss grad av kontroll, legitimitet og organisasjonskultur (Steen-Johnsen mfl., 2012). Aksjonsgrupper og organisasjoner som RW, som oppstår på Facebook, synes i større grad enn etablerte aktører å evne å ta i bruk det potensialet for toveiskommunikasjon som ligger i de nye kommunikasjonsmediene. Ikke bare til enveis informasjonsspredning og mobilisering, som mange gjør, men i all organisering og koordinering av frivillige aktiviteter. Hjemmesiden til RWTN - og særlig de lokale Facebook-gruppene fungerer på mange måter som digitale frivillighetssentraler, der det både 
blir formidlet konkrete behov fra mottak eller flyktninger selv, og der individer kan henvende seg for å få informasjon om hva de kan bidra med. Med bakgrunn i studier som viser at en av de mest sentrale barrierene for frivillig deltakelse er at en ikke har blitt spurt eller ikke vet hvor man skal begynne (se bl.a. Wollebæk mfl., 2015), kan en slik formidling av ulike måter å hjelpe på via nettsiden, sammen med interaksjon på en utbredt plattform som Facebook, fremstå som et nyttig virkemiddel for å senke terskelen for frivillig deltakelse.

Basert på de ovennevnte egenskapene utgjør RW på mange måter et godt eksempel på det Bennet og Segerberg (2012) betegner som en konnektiv handlingslogikk, som ikke er avhengig av tidkrevende og kostbare byråkratiske strukturer for å mobilisere til kollektiv handling i stor skala, og som gjør det enklere å tilpasse seg et bredt spekter av potensielle frivillige. Men funnene understreker samtidig hvordan ingen er «selvorganiserende». Særlig når et nettverk oppnår en viss størrelse, er de helt avhengig av ildsjeler og enkeltpersoner som investerer enormt mye tid og ressurser på å holde en viss grad av oversikt. Analysene tydeliggjør også hvordan en uformell organisering kan føre til utfordringer knyttet til økonomisk støtte og langsiktig planlegging, som kan bidra til stabilitet og forutsigbarhet over tid. Ikke bare illustrerer RW-casen hvordan interne behov for kontroll og langsiktighet oppstår, men også hvordan en bredere kontekst og eksterne aktørers krav og forventninger kan bidra til å «tvinge» en bevegelse inn i fastere former. Selv om det ikke er noen lovmessighet $i$ at organisasjonsutviklingen går fra løsere former mot mer hierarki og byråkrati, ser man gjerne tendenser til homogenisering av organiseringsformer - eller isomorfisme - særlig på felt som asyl- og flyktningfeltet, der staten deltar gjennom samarbeid og finansiering av tiltak og virksomheter (DiMaggio \& Powell, 1991). Selv om aktivitetene ikke nødvendigvis krever det, ser man derfor en tendens til at organisasjoner adopterer visse former og strukturer for å leve videre over tid - uavhengig av hvor effektivt det er (Meyer \& Brown, 1977). På mange måter antyder disse organisasjonsteoriene at sosiale bevegelsers fremvekst og suksess i begynnelsen nettopp ligger i å operere utenfor etablerte rammer og virkemidler, men at deres fremtid ligger i å bli en del av det etablerte systemet for langsiktighet og legitimitet. 
RW-casen illustrerer imidlertid hvordan overlevelse (i det minste i en tidlig fase) ikke nødvendigvis innebærer å måtte bli lik andre. Selv om gruppene på noen måter synes å tvinges inn i noe fastere former på grunnlag av juridiske krav og retningslinjer og omgivelsenes forventninger til hvordan en seriøs aktør skal være organisert, synes det som om RW-informantene aktivt jobber for å ikke bli som mer tradisjonelle aktører. De insisterer på å opprettholde en særpreget identitet som grasrotorganisasjon med flat og uformell struktur. En struktur som innebærer en hybrid form for organisering som kombinerer nettverk og hierarki (se Enjolras 2010 om såkalte nettverksorganisasjoner). Analysene tydeliggjør hvordan gruppene i utvalget har funnet ulike måter å løse utfordringer på; mens Norway-gruppen er opptatt av å bli mer profesjonell og «ordentlig», ligger en viktig del av identiteten til lokalgruppene i å nettopp beholde en mer uformell ad hoc-struktur. Denne fleksibiliteten og tilpasningsevnen muliggjøres på mange måter av todelingen mellom lokalt og nasjonalt nivå, der lokalgruppene er mer aktivitetsorienterte og den nasjonale jobber mer politisk. Nye kommunikasjonsformer ser ut til å bidra til å muliggjøre en slik hybriditet, og gi nye aktører som RW anledning til å utvikle nye måter å løse samfunnsutfordringer på.

Som beskrevet i kapitlets data- og metodedel, er denne studien gjennomført på ett tidspunkt da gruppene i utvalget var på ulike stadier i sine utviklingsprosesser. I etterkant av intervjuene har de fortsatt å utvikle seg i ulike retninger. Flere spørsmål reises både med tanke på den fremtidige bærekraften i RW-initiativet og på hvilken rolle denne typen uformelle aktører kan spille i samfunnet. For det første ville det vært interessant å følge RW-gruppenes videre utvikling: Eksisterer de fremdeles, og har de funnet nye arbeidsområder etter hvert som behovet på mottak har blitt mindre? Hvordan har gruppene løst utfordringene med å få på plass demokratiske strukturer? Den norske konteksten er også spesiell med tanke på forholdet mellom staten og organisasjonssamfunnet: Hvordan har RW arbeidet og utviklet seg i Norge sammenlignet med tilsvarende bevegelser i andre europeiske land?

For det andre: Hva sier det at en ny aktør som RW fikk slik gjennomslagskraft om det norske mottakssystemet og etablerte aktørers evne til å agere raskt og effektivt i ekstraordinære situasjoner? Med kunnskapen 
om hvordan både nye og etablerte aktører supplerte hverandre på en viktig måte (Fladmoe mfl., 2016) er det også relevant å se på hvorvidt det er rom for ulike grader av formalitet og mer hybride former for organisering på et sterkt regulert felt som flyktning- og asylfeltet, og på andre felter.

\section{Referanser}

Arnesen, D., Sivesind, K.H., \& Gulbrandsen, T. (2016). Fra medlemsbaserte organisasjoner til koordinert frivillighet? Det norske organisasjonssamfunnet fra 1980 til 2013. Rapport 5/2016. Oslo/Bergen: Senter for forskning på sivilsamfunn og frivillig sektor.

Barrabasi, A. L. (2002). Linked. London: Penguin Books.

Bennet, L., \& Segerberg, A. (2012). The logic of connective action. Information, Communication and Society, 15 (5), s. 739-768.

Della Porta, D., \& Diani, M. (2006). Social Movements. An Introduction (2. utg.). Oxford: Blackwell Publishing.

Diani, M. (1992). The concept of social movement. The Sociological Review, 40 (1), S. 1-25.

DiMaggio, P.J., \& Powell, W.W. (1991). The iron cage revisited: Institutional isomorphism and collective rationality in organizational fields. American Sociological Review, 48 (2), s. 147-160.

Eimhjellen, I., Wollebæk, D., \& Strømsnes, K. (2013). Associations Online: Barriers for using web-based communication in Voluntary Associations. Voluntas, 25, s. $730-753$.

Eimhjellen, I. (2013). Internet communication. Does it strengthen local voluntary organizations? Nonprofit and Voluntary Sector Quarterly, s. 1-20. DOI: $10.1177 / 0899764013487996$.

Eimhjellen, I. (2018). Flyktningengasjement i sosiale medier. Et mediepraksisperspektiv på flyktningsituasjonen i 2015. I B. Enjolras \& I. Eimhjellen (Red.). Fra kollektiv til konnektiv handling? Nye former for samfunnsengasjement og kollektiv handling i Norge. Cappelen Damm Akademisk.

Eimhjellen, I. (2016). Nytt lokalt engasjement: Ein studie av Bærekaftige Liv i Bergen. I I. Eimhjellen \& G. Ødegård. Klima og migrasjon. To casestudiar av sivilsamfunnsorganisering i ei ny tid. Rapport 2/2016. Bergen/Oslo: Senter for forskning på sivilsamfunn og frivillig sektor.

Enjolras, B. (2010) Networked voluntary organizations as hybrid organizations. The case of Amnesty International Norway. Paper presentert på The $9^{\text {th }}$ International Conference of the International Society for Third Sector Research (ISTR). Kadir Has University. Istanbul, Tyrkia, 7-10. Juli 2010. 
Enjolras, B., Steen-Johnsen, K., \& Wollebæk, D. (2013). Social media and mobilization to offline demonstrations: Transcending participatory divides? New Media and Society, 15 (6), s. 890-908. DOI: 10.1177/1461444812462844

Fladmoe, A., Sætrang, S., Eimhjellen, I., Steen-Johnsen, K., \& Enjolras, B. (2016). Nordmenns bidrag i flyktningsituasjonen 2015/2016. Rapport 6/2016. Oslo/Bergen: Senter for forskning på sivilsamfunn og frivillig sektor.

Goffman, Erving (1974). Frame Analysis. Cambridge, MA: Harvard University Press. Hustinx, H., \& Lammertyn, F. (2003). Collective and Reflexive Styles of Volunteering: A Sociological Modernization Perspective. Voluntas, 14, s. 167-187

McAdam, D., McCarthy, J.D., \& Mayer, N.Z. (1996). Comparative Perspectives on Social Movements. Political Opportunities, Mobilizing Structures, and Cultural Framings. Cambridge: Cambridge University Press.

Meyer, J.W., \& Rowan, B. (1977). Institutionalized Organizations: Formal structure as myth and ceremony. American Journal of Sociology, 83 (2), s. 340-363.

Seippel, $\varnothing$. (2001). From Mobilization to Institutionalization? The Case of Norwegian Environmentalism. Acta Sociologica, 44 (2), s. 123-137

Seippel, Ø. (2003). Sosiale bevegelser: Innføring, oversikt, utfordringer. Sosiologisk tidsskrift, 11 (2), s. 181-202.

Shirky, C. (2008). Here comes everybody. The Power of organizing without organizations. London: Penguin Books.

Snow, D. A., \& Soule, S.A. (2010). A primer on social movements. New York: Norton \& Company.

Steen-Johnsen, K., Enjolras, B., \& Kruse, A. E. (2012). Nettverkssamfunn og frivillige organisasjoner. Rapport 1/2012. Oslo/Bergen: Senter for forskning på sivilsamfunn og frivillig sektor.

Stalder, F. (2006). Manuel Castells. The theory of the network society. Cambridge: Polity Press.

Sætrang, S. (2016). «Ikke bare en Facebook-gruppe»: En case-studie av Refugees Welcome-nettverket i Norge. Rapport 9/2016. Bergen/Oslo: Senter for forskning på sivilsamfunn og frivillig sektor.

UDI (2016). Årsrapport 2015 for Utlendingsdirektoratet. Oslo: UDI.

Wollebæk, D., Sætrang, S., \& Fladmoe, A. (2015). Betingelser for frivillig innsats. Motivasjon og kontekst. Rapport 1/2015. Oslo/Bergen: Senter for forskning på sivilsamfunn og frivillig sektor. 



\title{
Flyktningengasjement i sosiale medier. Et mediepraksisperspektiv på flyktningsituasjonen i 2015
}

\section{Ivar Eimhjellen}

NORCE

\begin{abstract}
This chapter is based on a quantitative study of Norwegians' social media engagement for helping refugees in Norway in 2015, and how this was related to other acts and forms of help. I argue for and utilize a social and practice oriented media-perspective in which I conceptualize social media as practice and connected to other forms of practice in the social space. I find that social media, Facebook in particular, was part of disseminating attention and engagement for helping refugees rapidly all over Norway. As such, Facebook manifested itself as an infrastructure for the mobilization and organizing of volunteer contributions during the refugee situation. However, the scope of social media-assisted volunteer contributions was relatively small compared to the contributions through established voluntary organizations. Likewise, the established media-channels were also more important than social media for the spread of information on how to contribute. Based on this study, I claim that social media as an infrastructure for the mobilization and organizing of volunteer contributions serves a supplemental, albeit important function compared to established infrastructures. Social media supplement the established media and voluntary organizations by increasing the speed and geographical scope of mobilizing and organizing collective action.
\end{abstract}

Keywords: social media, refugees, media as practice, mobilization, volunteering

Sitering av denne artikkelen: Eimhjellen, I. (2018). På Facebook for flyktninger. Flyktningengasjement i sosiale medier. Et mediepraksisperspektiv på flyktningsituasjonen i 2015. I B. Enjolras \& I. Eimhjellen (Red.), Fra kollektiv til konnektiv handling? Nye former for samfunnsengasjement og kollektiv handling i Norge (s. 189-210). Oslo: Cappelen Damm Akademisk. https://doi.org/10.23865/noasp.45.ch7

Lisens: CC BY-NC 4.0 


\section{Introduksjon}

Året 2015 var et år der flyktningstrømmen til Europa og konsekvensene av den både umiddelbart og på lengre sikt fikk stor oppmerksomhet, også i Norge. ${ }^{1}$ For eksempel ble ordet «flykning» nevnt i over 10 ooo norske medieoppslag (på nett og papir) i løpet av 2015, sammenlignet med 3315 oppslag året før (A-tekst/Retriever). I ankomstland, transittland og der flyktningene til slutt søkte asyl, skapte den store mengden av flyktninger mange utfordringer for de offentlige mottakssystemene. Som diskutert i de foregående kapitlene skapte flyktningsituasjonen samtidig et stort sivilt engasjement for å hjelpe de nyankomne gjennom fysiske handlinger og hjelpetiltak. Samtidig må man også ha i minne at flyktningsituasjonen også skapte mye motstand og negative reaksjoner (Ekman, 2018; Thorleifsson, 2016; Europaparlamentet, 2015).

Som undersøkt i kapittel 5 ble storparten av hjelpebidragene i flyktningsituasjonen utført gjennom tradisjonelle frivillige organisasjoner, mens rundt 20 prosent av hjelpebidragene ble utført i regi av nyopprettede initiativ eller organisert på egen hånd eller i lag med kjente. Samtidig, og som undersøkt i kapittel 6, hadde sosiale medier en helt sentral rolle i flere av de nyopprettede Refugees Welcome-initiativene. Disse nye initiativene fikk også mye medieoppmerksomhet og ble for eksempel nevnt i over 1200 medieoppslag (på nett og papir) mellom august og desember 2015 (A-tekst/Retriever). Basert på data fra Facebook og fra en befolkningssurvey skal jeg i dette kapitlet undersøke nærmere de hjelpebidragene som ble etablert og utviklet gjennom sosiale medier, og hvordan disse bidragene var knyttet til andre former for bistand til flyktningene. Jeg ønsker her å undersøke hvordan hjelpeengasjement gjennom sosiale medier var koblet sammen med andre former for hjelpeengasjement. Som et teoretisk perspektiv for analysene vil jeg dra nytte av og argumentere for et sosialt og praksisorientert medieperspektiv (Couldry, 2012), der man søker å avdekke hvordan medier gjennom menneskelig praksis blir (eller ikke blir) vevd inn i det sosiale rommet, og hvordan medierelaterte praksiser står i forhold til andre menneskelige praksisformer. I kapitlet undersøker

1 I løpet av året kom i overkant av en million flyktninger over Middelhavet til Europa http://www. unhcr.org/afr/news/latest/2015/12/5683dob56/million-sea-arrivals-reach-europe-2015.html 
jeg derfor følgende problemstilling: Hvilke sosiale mediebaserte hjelpebidrag vokste frem under flyktningsituasjonen $i$ Norge i 2015, og hvordan var disse hjelpebidragene knyttet til andre engasjementsformer?

Videre i kapitlet vil jeg først kort diskutere begrepene samfunnsengasjement og frivillig arbeid, og relevante kjennetegn ved sosiale medier og hvilke implikasjoner de potensielt kan ha for mobilisering og organisering av samfunnsengasjement. Jeg vil så gjøre rede for og argumentere for bruken av det sosiale og praksisorienterte perspektivet på medier for undersøkelser av samfunnsmessige implikasjoner av sosiale medier. Datagrunnlag og metoder blir så skildret og diskutert før jeg legger frem analysen og tolkninger av datagrunnlaget. Jeg avslutter kapitlet med en diskusjon av funnene og hva de kan tilføre av mer generell kunnskap om funksjonene og konsekvensene av sosiale medier for mobilisering og organisering av samfunnsengasjement.

\section{Samfunnsengasjement og sosiale medier}

Som sosialt fenomen i en vestlig kontekst blir samfunnsengasjement gjerne forstått i lys av to sentrale dimensjoner: politisk deltakelse på den ene siden og frivillighet på den andre siden. På den politiske dimensjonen vil samfunnsengasjement kunne ses som et eksplisitt politisk engasjement som inkluderer aktiviteter som har som mål eller får som konsekvens å endre, direkte eller indirekte, offentlige myndigheters handlinger (Verba, Nie, \& Kim, 1978). Samtidig kan også samfunnsengasjement bli forstått som frivillig engasjement med ulike former for altruistisk adferd med mål om å hjelpe andre (en gruppe, en organisasjon eller samfunnet generelt) uten å forvente materiell gevinst (Musick \& Wilson, 2008, s. 3). I Norge er frivillig arbeid en svært utbredt aktivitet der over halvparten av befolkningen er aktive (Enjolras \& Strømsnes, 2018). I Norge og i Skandinavia for øvrig er også slikt engasjement i størst grad knyttet til aktiviteter i idretts-, hobby- og fritidsorganisasjoner der man deltar både for egen dels skyld og for å hjelpe andre (Henriksen, Strømsnes, Svedberg, 2018). Hjelpebidragene under flyktningsituasjonen i 2015 gav oss et konkret uttrykk for den store kapasiteten som ligger i nordmenns samfunnsengasjement når det oppstår umiddelbare hjelpebehov hos andre. Som 
diskutert i de foregående kapitlene illustrerte flyktningsituasjonen også at slikt samfunnsengasjement gjerne er kombinasjoner av altruistisk, frivillig og politisk engasjement der ikke bare bistands- og hjelpeorganisasjoner er involvert, men et bredt spekter av frivillige organisasjoner og nye sosiale medier-baserte initiativ. Flyktningsituasjonen er på denne måten et godt egnet case til å undersøke utviklingstrekk i nordmenns samfunnsengasjement og implikasjonene av sosiale medier.

Begrepet sosiale medier blir gjerne brukt som et samlebegrep for ulike typer nettsider som i en eller annen form involverer brukere med egne profiler som er knyttet til hverandre i et digitalt nettverk (Boyd \& Ellison, 2007). Et særtrekk ved sosiale medier, og som også skiller dem fra andre medier, er at de på samme tid både er 1) digitale medie-og kommunikasjonsplattformer og 2) digitale sosiale nettverk (Enjolras, Karlsen, Steen-Johnsen \& Wollebæk, 2013). Som medium er forskjellen fra tradisjonelle massemedier at de i større grad er preget av mediekonvergens med et mangfold av former for kommunikasjon, av ulike grader av interaktivitet og av typer medieinnhold: tekst, lyd, bilder eller video. Sosiale medier har på denne måten mange flere innebygde handlingsmuligheter enn tidligere medier (Boyd, 2011), og enkeltindivider er nå i større grad selv aktive som produsenter og avsendere av medieinnhold. Dette har blant annet skapt nye måter å være samfunnsengasjert på. Som digitale nettverk kobler også de sosiale medieplattformene individer sammen i større nettverksstrukturer som potensielt kan koble hele befolkninger og samfunn sammen. Sosiale medier utgjør på denne måten egne nettverks- og handlingsstrukturer og har skapt nye måter å mobilisere og organisere samfunnsengasjement på. Et kjennetegn ved sosiale medier som ofte blir trukket frem i denne sammenhengen, er evnene de har til å koble sammen og mobilisere mennesker på en mye raskere måte enn før gjennom mobiliseringsbølger og «viral spredning». Sosiale medier kan derfor ses som supplement til både etablerte mediekanaler og til tradisjonelle frivillige organisasjoner for mobilisering og organisering av samfunnsengasjement. Det er ikke lenger bare organisasjoner eller sentraliserte kringkastere som setter premissene for massemediert informasjonsflyt og kommunikasjon. Gjennom sosiale medier har uformelle grupper og enkeltindivider fått økte muligheter til mobilisering og organisering av samfunnsengasjement, raskere og i større skala enn før. 
De egenskapene som ligger i sosiale medier, og de potensielle konsekvensene disse kan ha for mobilisering og organisering av samfunnsengasjement, har av flere samfunnsforskere blitt omtalt ikke bare som supplerende, men også som å kunne erstatte eksisterende mobiliseringsog organiseringsstrukturer. Som diskutert i innledningskapitlet blir nettverksstrukturen og kommunikasjons- og organiseringsmulighetene i sosiale medier hevdet å legge til rette for «konnektiv handling» (Bennet \& Segerberg, 2013), som utfordrer logikken i å organisere og sentralisere informasjon, kunnskap, interesser og interne maktfordelinger i egne avgrensede organisasjoner. Det blir også hevdet at nettverksteknologi har redusert omkostningene ved kollektiv handling så mye at organisasjoner i seg selv er blitt mindre viktige (Shirky, 2008). I stedet for at organisasjoner må arbeide for å skape engasjement blant individer, så kan engasjement og initiativ komme fra individene selv. De digitale nettverkene er her hevdet å være noe mer enn kommunikasjonssystemer og at de i seg selv er blitt egne og fleksible organisasjonsstrukturer (Bennet \& Segerberg, 2013). I Norge har tidligere studier vist at sosiale medier kan konstituere nye måter å mobilisere til offline-engasjement, og at de kan supplere etablerte og tradisjonelle mobiliseringsstrukturer (Enjolras, Karlsen, Steen-Johnsen, Wollebæk, 2013). Her ser man sosiale medier som supplement til både etablerte mediekanaler og til organisasjoner som informasjonsstrukturer for mobilisering av engasjement.

Generelt er det også mange studier som finner en positiv sammenheng mellom bruk av sosiale medier og ikke-digitale former for samfunnsengasjement (de Zuniga et al., 2009, 2010; Lutz, mfl., 2014). Her er det for eksempel funnet sammenhenger mellom å like politisk innhold på Facebook og deltakelse i politiske organisasjoner ellers (Vitak et al., 2011) og mellom medlemskap i politiske grupper på nett og offline politisk deltakelse (Conroy, Feezell \& Guerrero, 2012). Metastudier av internettbruk og nivå av sosialt og politisk engasjement har også vist at det er positive sammenhenger mellom internettbruk og denne type engasjement, i særskilt grad hos unge. Likevel er bare et mindretall av denne type dokumenterte sammenhenger statistisk signifikante, og man kan derfor ikke si så mye om kausale effekter generelt sett (Boulianne, 2009; 2015). Oppsummert kan vi derfor si at samfunnsengasjement på nett og 
samfunnsengasjement ellers ser ut til å ha en klar sammenheng selv om årsaksforholdet er uavklart (se ellers kapittel 4 i denne boken).

Videre er det her også et viktig poeng å ha med seg at det er forskjeller på de innebygde potensialene i medieteknologier og hvordan de faktisk blir brukt av mennesker. Når man skal undersøke de samfunnsmessige konsekvensene av ny medieteknologi, vil det fra et sosialkonstruktivistisk perspektiv være viktig å kunne ta hensyn til sosial kontekst (Sassen, 2002; Westrum, 1991). Effekter av sosiale medier vil ikke komme av seg selv og vil ikke nødvendigvis være like i alle sosiale kontekster eller på ulike samfunnsnivå. De samfunnsmessige virkningene av sosiale medier vil bli formet av eksisterende strukturer, motivasjoner, praksiser, interesser, normer og kulturer der de blir tatt i bruk. I Norge vil for eksempel effektene av sosiale medier på frivillig og politisk engasjement kunne bli formet av de etablerte strukturene og praksisene rundt frivillig innsats, med en sterk organisasjonskultur og en tett sammenknytning mellom frivillige og frivillige organisasjoner (Wollebæk \& Selle 2002; Enjolras \& Strømsnes, 2018). Samtidig kan også de sosiale mediene være en del av utviklingen mot en mer refleksiv og fleksibel form for frivillig innsats (Eimhjellen \& Ljunggren, 2017; Eimhjellen, 2018; Eimhjellen, SteenJohnsen, Folkestad \& Ødegård, 2018). Det vil derfor være viktig å studere digitale engasjementsformer i sammenheng med eksisterende engasjementsformer og å se på funksjonene og rollene som sosiale medier har i konkrete situasjoner vis-à-vis etablerte mobiliserings- og organisasjonspraksiser. Det vil her være nyttig å ha et grunnleggende teoretisk perspektiv å ta utgangspunkt i. Videre legger jeg derfor frem og diskuterer noen sentrale elementer fra et mediesosiologisk perspektiv på de samfunnsmessige implikasjonene av sosiale medier, og som jeg vil legge til grunn for analysene og konklusjonene i dette kapitlet.

\section{Medier som praksis - en sosial medieteori for samfunnsengasjement}

For å ta hensyn til sosial kontekst for teknologi og mediebruk vil jeg i det følgende argumentere for et mediesosiologisk og praksisorientert medieperspektiv (Couldry, 2012) når en skal undersøke sosiale implikasjoner av 
sosiale medier, både generelt og for samfunnsengasjement spesielt. I likhet med Kaun og Uldam i Sverige (2017) tar jeg her utgangspunkt i Nick Couldrys sosialt orienterte medieteori (2012) i undersøkelsen av sosiale mediers rolle i hjelpeengasjementet under flyktningsituasjonen i 2015. Det mest sentrale poenget som jeg vil trekke ut fra denne medieteorien, er fokuset på medienes innvevning i det sosiale rommet - å kunne analysere mediepraksiser i sammenheng med andre praksisformer og å studere medienes virkninger på menneskelig agens. Knyttet til flyktningsituasjonen og samfunnsengasjement handler dette om de handlingsmulighetene som sosiale medier legger til rette for når det gjelder mobilisering og organisering av samfunnsengasjement, hvordan de sosiale mediene blir brukt til slik mobilisering og organisering, og hvordan disse mediepraksisene er knyttet sammen med andre praksisformer i etablerte mobiliserings- og organisasjonsstrukturer. Det handler altså her om å forstå hvordan mediepraksiser blir integrert i samfunnet, og hvordan de påvirker og blir tilpasset etablerte praksiser og strukturer.

Ifølge Couldry handler mediesosiologi om «... the specific regularities in our actions related to media and the regularities of context and resources that make certain types of media-related actions possible or impossible, likely or unlikely» (Couldry, 2012, s. 33). Han argumenterer her for se på medier som praksis, som noe mennesker gjør - en form for handling. At sosiale medier innehar mange flere handlingsmuligheter enn tidligere medier (Boyd, 2011), bare understreker hvorfor et slikt perspektiv er nyttig. Samtidig bør også disse handlingsmulighetene kunne ses i sammenheng med eller sammenlignes med tilsvarende eller lignende handlingsmuligheter utenfor mediene. Gjennom sosiale medier kan man blant annet enkelt donere penger, signere underskriftskampanjer, melde seg til frivillig arbeid, bli med i protestgrupper og aksjoner eller bli medlem i organisasjoner. En kan få tilgang til medieinnhold, politisk informasjon og selv dele dette med eget nettverk, og en kan selv mobilisere og organisere større hendelser og aksjoner. Utbredelsen av slike handlingsmuligheter bør her studeres i sammenheng med tilsvarende eller lignende handlingsmuligheter som eksisterer ellers, for eksempel gjennom de etablerte og institusjonaliserte formene for pengeinnsamling, frivillig innsats, informasjonsspredning, mobilisering og organisering av samfunnsengasjement i etablerte 
mediekanaler og i frivillige organisasjoner. Et slikt praksisperspektiv på sosiale medier vil være svært nyttig i en kritisk analyse av den rollen som sosiale medier hadde i hjelpebidragene under flyktningsituasjonen.

For nettopp å undersøke hvilke sosiale medier-baserte hjelpebidrag som ble utviklet under flyktningsituasjonen i Norge i 2015, og hvordan disse var knyttet til andre engasjementsformer, skal jeg derfor studere utbredelsen av hjelpegrupper for flyktninger på Facebook, både i omfang, over tid og geografisk. Deretter vil jeg undersøke og diskutere utbredelsen av disse hjelpegruppene opp mot gruppenes koblinger til etablerte organisasjoner og til nordmenns hjelpebidrag under flyktningsituasjonen mer generelt. Før jeg begynner på den empiriske analysen, skal jeg først gjøre rede for datagrunnlaget og metodene for datainnsamling og analyser.

\section{Metodisk tilnærming}

Metodisk har jeg i denne studien brukt en kvantitativ tilnærming, der jeg har søkt å registrere og analysere omfanget av det sosiale fenomenet som er i fokus. Mer konkret innebar dette opptellinger av uttrykk for menneskelig hjelpepraksis i forbindelse med flyktningsituasjonen i 2015, både gjennom sosiale medier og ellers. Det man tjener på å utvikle slik breddekunnskap, kan hevdes å gå på bekostning av dybdekunnskap og kvalitative forståelser av meninger, handlinger og intensjoner omkring slike hjelpepraksiser. Jeg vil her understreke behovet for kvantitative studier på dette feltet for å søke å avdekke mer generelle tendenser, utbredelse og eventuelle sammenhenger. Kumulativt vil denne studien sammen med andre studier av flyktningengasjement og andre metodiske tilnærminger (se f.eks. kapittel 5 og 6 i denne boken, eller Kaun og Uldam (2017)) kunne gi oss en mer helhetlig forståelse av nye former og uttrykk for samfunnsengasjement gjennom sosiale medier og sammenhenger mellom ulike hjelpepraksisformer.

I denne studien har jeg hovedsakelig brukt to datakilder: registreringer av hjelpegrupper på Facebook og utvalgte kjennetegn ved disse gruppene, og spørreskjemadata (individ) fra Norsk medborgerpanel om frivillige hjelpebidrag under flyktningsituasjonen. Siden Facebook er det mest brukte sosiale mediet i Norge, med 72 prosent av internettbefolkningen 
som daglige brukere (SSB, 2016), har jeg konsentrert meg om mobilisering og organisering av flyktningengasjement gjennom sider og grupper på denne sosiale nettplattformen. Informasjonen om Facebook-gruppene har jeg samlet inn og registrert manuelt ved bruk av min egen personlige profil på Facebook. Datainnsamlingen ble gjort i perioden juli-august 2016, og dataene representerer derfor et «øyeblikksbilde» av gruppene på registreringstidspunktet. I registreringsarbeidet søkte jeg etter hjelpegrupper og sider som ble opprettet på Facebook i løpet av 2015. ${ }^{2}$ Søkene ble gjort gjennom søkefeltet på Facebook ved hjelp av søkeord som bistand, hjelp, støtte, flyktning og Norge, både for seg selv og i kombinasjoner, og både på norsk og på engelsk. Ved hjelp av informasjonen som var tilgjengelig i disse gruppene, opprettet jeg et register over kjennetegn ved gruppene, som for eksempel oppstartsdato, geografisk område som gruppen omfattet, og tall på medlemmer. I medlemsbaserte grupper måtte jeg selv bli medlem for å få tilgang. Analyser av materialet er gjort i form av univariate fordelinger på relevante variabler.

Ved innsamling av samfunnsvitenskapelig forskningsdata fra internett og sosiale medier er det flere forskningsetiske hensyn å ta, for eksempel når det gjelder samtykke, personvern og privatlivets rett. Et sentralt spørsmål er for eksempel i hvilken grad informasjon fra nettsider og sosiale medier er offentlig eller privat. I juridisk forstand vil samlinger av mer enn 20-30 personer i et nettforum eller en Facebook-gruppe kunne defineres som et offentlig rom, og ytringer i slike rom vil derfor være offentlige. ${ }^{3}$ Likevel vil ikke de juridiske definisjonene alltid stemme overens med deltakernes og gruppenes egne oppfatninger av disse arenaene. Forskere skal derfor også ta hensyn til aspekter som dette. Dette innebærer blant annet at informasjon fra helt åpne fora på nett (nettsider, blogger, åpne Facebook-grupper) som hovedregel kan brukes fritt av forskere uten samtykke, men at respekt for privatliv og nære relasjoner alltid skal vurderes (NESH, 2014). I forum eller sider som er delvis eller helt lukket, er ikke informasjonen tilgjengelig for alle og kan ikke uten videre bli brukt til

2 I det følgende brukes betegnelsen «grupper» for disse facebookgruppene/sidene.

3 Jf. lov om endringer i straffeloven $1902 \mathrm{mv}$. (offentlig sted, offentlig handling m.m.): https:// lovdata.no/dokument/LTI/lov/2013-05-24-18 og Ot.prp. nr. 90: https:/www.regjeringen.no/ contentassets/43d34ad472404159a827a3bf62e822f1/no/pdfs/otp20032004009oooodddpdfs.pdf 
forskningsformål uten samtykke. I dette kapitlet blir ikke informasjon om enkeltindivider eller personidentifiserende opplysninger utlevert på noe vis, og mye av informasjonen som er samlet inn, kan karakteriseres som metadata, der det er snakk å telle grupper og å kartlegge kjennetegn ved gruppene/sidene. Det er altså ikke enkeltdeltakere og deres handlinger og ytringer som er i fokus. Studien i dette kapitlet blir derfor sett som å være i tråd med og å følge de etiske retningslinjene fra Den nasjonale forskningsetiske komité (NESH), samt retningslinjene fra den internasjonale organisasjonen Association of Internet Researchers (AOIR, 2012). Datainnsamlingen ble også meldt inn til og godkjent av Personvernombudet for forskning/Norsk senter for forskningsdata (NSD).

Den andre datakilden er undersøkelsen fra Norsk medborgerpanel i mars 2016 (som også er grunnlag for kapittel 5) blant 460 tilfeldig rekrutterte nordmenn mellom 18 og 95 år om frivillig engasjement under flyktningsituasjonen i 2015. ${ }^{4}$ Basert på disse dataene utfører jeg enkle univariate analyser der jeg viser prosentvis fordeling på utvalgte variabler. Til sammen mener jeg at disse to datakildene utgjør et nyttig grunnlag for å analysere problemstillingen i dette kapitlet som handler om omfang og kjennetegn ved mediepraksiser knyttet til flyktningengasjementet og hvordan disse mediepraksisene var knyttet til andre praksisformer i engasjementet under flyktningsituasjonen i Norge i 2015.

\section{Kartleggingen av hjelpegruppene på Facebook}

For å svare på første delen av problemstillingen - om hvilke sosiale medierbaserte hjelpebidrag som vokste frem under flyktningsituasjonen, har jeg kartlagt fremveksten av hjelpegrupper på Facebook i løpet av 2015. I denne kartleggingen fant jeg frem til 147 grupper som ble opprettet i løpet av 2015, og som hadde som formål å hjelpe flyktninger som kom til Norge (se figur 1 under). Omtrent 100 av disse var på ulike måter knyttet til nettverket «Refugees Welcome», 25 var «Dråpen i Havet»-grupper, 6 var

4 Undersøkelsen ble finansiert av Universitetet i Bergen (UiB) og Uni Research Rokkansenteret. Data er gitt av UiB, gjort tilgjengelig av Ideas2Evidence, og distribuert av Norsk senter for forskningsdata (NSD). Verken UiB, Uni Research Rokkansenteret eller NSD er ansvarlige for den analysen/tolkingen av data som er presentert her. 


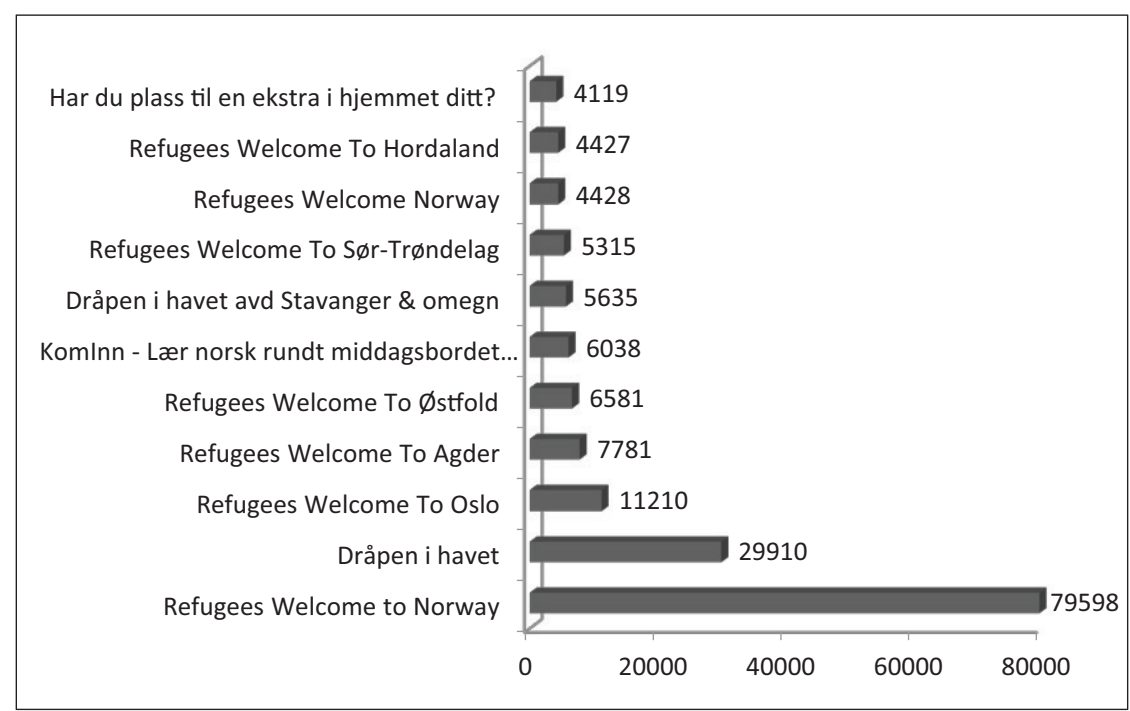

Figur 1: De 10 største hjelpegruppene på Facebook ut fra medlemstall. (Tot. $N=147$ )

knyttet til initiativet «KomInn - Lær norsk rundt middagsbordet». Resten var enkeltstående hjelpegrupper. Av de 147 gruppene i datamaterialet var Refugees Welcome To Norway den desidert største med 79598 medlemmer på registreringstidspunktet. Dråpen i havet kom på andreplass med 29910 medlemmer. På tredjeplass finner vi gruppen Refugees Welcome To Oslo med 11210 medlemmer. ${ }^{5}$ Det var altså minst 80 ooo nordmenn som gjennom sine gruppemedlemskap eller liker-klikk på Facebook var koblet til et gruppenettverk som gav tilgang til informasjon og et sted å kommunisere ut budskap knyttet til bistand og hjelp til flyktninger.

Det må likevel understrekes at medlemskap i slike grupper ikke nødvendigvis innebærer at man er aktiv, følger med på det skjer i gruppene, eller får informasjon fra gruppene automatisk. En analyse av de gruppene som var åpne (46 stk.), ved hjelp av analyseverktøyet sociograph.io viste for eksempel at aktivitetsgraden var større i store grupper, men at den ikke var direkte proporsjonal med gruppestørrelsen, samt at aktivitetsomfanget var avhengig av type aktivitet der de aktivitetsformene som krever minst innsats, var størst i omfang, her i form av «likes». Aktivitetene i

5 Det var også to grupper med navnet Refugees Welcome to Norway. Den ene var den største gruppen, mens den andre hadde om lag 4500 medlemmer. 
disse gruppene har videre kunnet spre innhold og kommunikasjon om flyktningengasjementet til mange andre på Facebook utenfor disse gruppene gjennom spredning i de aktives egne Facebook-nettverk. Uten å ha målt det direkte i denne studien kan vi bare konstatere at potensialet for vidtrekkende informasjonsspredning og mobilisering i disse gruppene var stort.

Facebook-dataene viser videre at det bare var et fåtall grupper som hadde svært mange medlemmer. De tre nevnte gruppene var de eneste som hadde over 10 ooo medlemmer. Fem grupper hadde mellom 5000 og 10 ooo medlemmer, mens hele 86 grupper hadde mellom 100 og 5000 medlemmer. 51 hadde under 100 medlemmer. Størrelsen på gruppene kan vi trolig knytte til deres geografiske og befolkningsmessige nedslagsfelt, der RWTN-gruppen og Dråpen i havet er nasjonale i omfang, og til at Oslo er den største byen i Norge. De mellomstore gruppene var gjerne knyttet til regioner og mindre byer, mens de mindre gruppene var knyttet til mindre tettsteder og små lokale initiativ.

I de ulike Facebook-gruppene fant jeg så frem til dato for oppretting. På bakgrunn av denne informasjonen har jeg laget en tidslinje for fremveksten og utviklingen av Facebook-engasjementet i Norge. Som vi ser i figur 2 under ble ni grupper opprettet mellom januar og juli 2015. Men det var først etter opprettelsen av «Refugees Welcome To Norway» den 20. august at fremveksten virkelig skjøt fart. På omtrent en måned, fra 20. august og ut september, ble det opprettet 73 grupper rundt omkring i Norge (de fleste av disse som undergrupper av Refugees Welcome to Norway). Som illustrasjon på denne spredningen er gruppene plottet inn manuelt på et norgeskart til høyre i figur 2 .

Når vi undersøker den geografiske spredningen av Refugees Welcome-gruppene enda mer i detalj (av de 147 som kunne plasseres ved hjelp av tilgjengelig informasjon), ser vi at 39 prosent av dem var plasserte på Østlandet (56 stk.), 17 prosent på Vestlandet (24 stk.), 11 prosent i NordNorge (16 stk.), 10 prosent i Trøndelag (14 stk.) og 8 prosent på Sørlandet (12 stk.). Den store mengden av hjelpegrupper på Østlandet kan trolig forklares med en større tilkomst av flyktninger i denne regionen. Men selv om konsentrasjonen av hjelpegrupper var tettest på Østlandet, var det likevel Nordland fylke som hadde flest grupper (13 stk.) om vi ser 


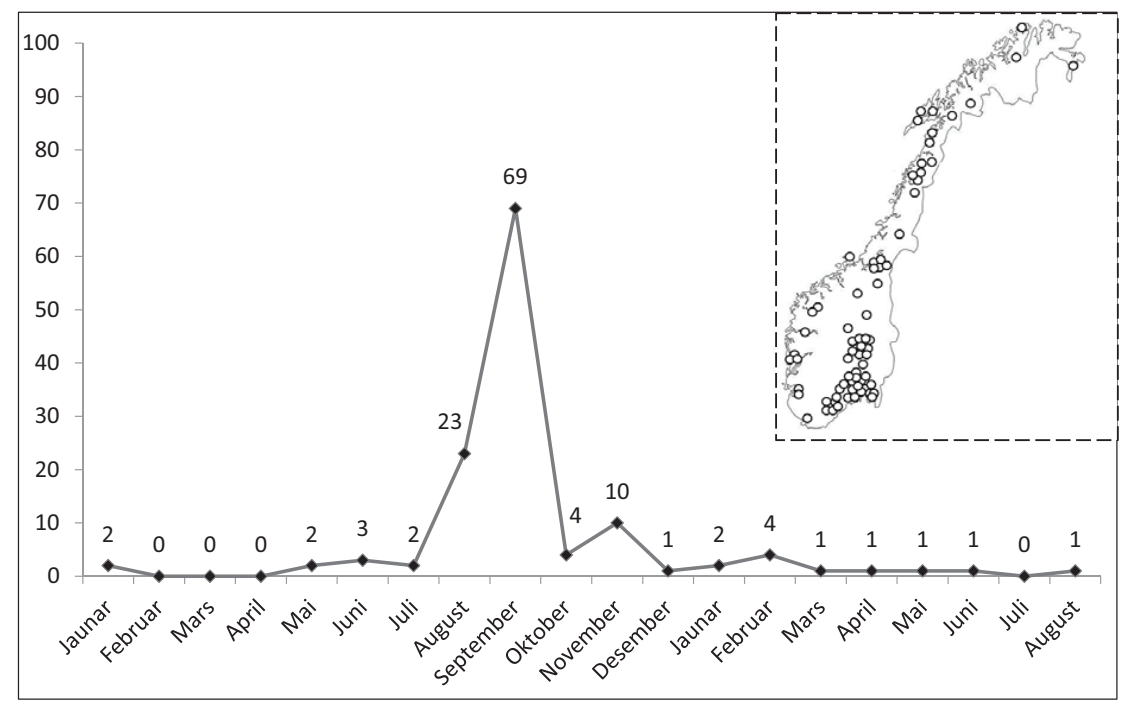

Figur 2: Tidslinje for oppretting av hjelpegrupper i Norge

det fylkesvis. Tall fra UDI viser her at Nordland hadde flest asylsøkere i mottak i 2015 av alle fylkene i Norge (3035 stk. - 10 prosent av total) (UDI, 2016). Til sammenligning registrerte jeg 10 hjelpegrupper hver $\mathrm{i}$ Akershus, Oppland og Sør-Trøndelag, mens det var færrest grupper i Troms (2 stk.) og Finnmark (1 stk.). Det ser altså ut til å være en kobling mellom geografisk spredning av Facebook-engasjement og ankomst og plassering av flyktninger. Dette ser vi også om vi undersøker gruppenes virkeområde mer konkret, der kommuner ser ut til å være de sentrale enhetene. Det var flest grupper som hadde kommunen som geografisk nedslagsfelt -38 prosent ( 55 stk.). En del fokuserte også på et distrikt som omfattet flere kommuner - 23 prosent (34 stk.), 15 prosent av gruppene var fylkesbasert (22 stk.), og 16 prosent var nasjonale i omfang (25 stk.). Bare mellom 3 og 1 prosent hadde en by/bydel/tettsted som geografisk nedslagsfelt (1-5 stk.).

Det ser altså ut til at etablerte kommunegrenser utgjorde en naturlig avgrensning for organisering og mobilisering av det sosiale medierinitierte flyktningengasjementet. Selv om mobilisering gjennom sosiale medier i prinsippet er mindre avhengig av geografi og kommunegrenser, var det kommuner som fikk ansvar for å ta imot flyktninger, og 


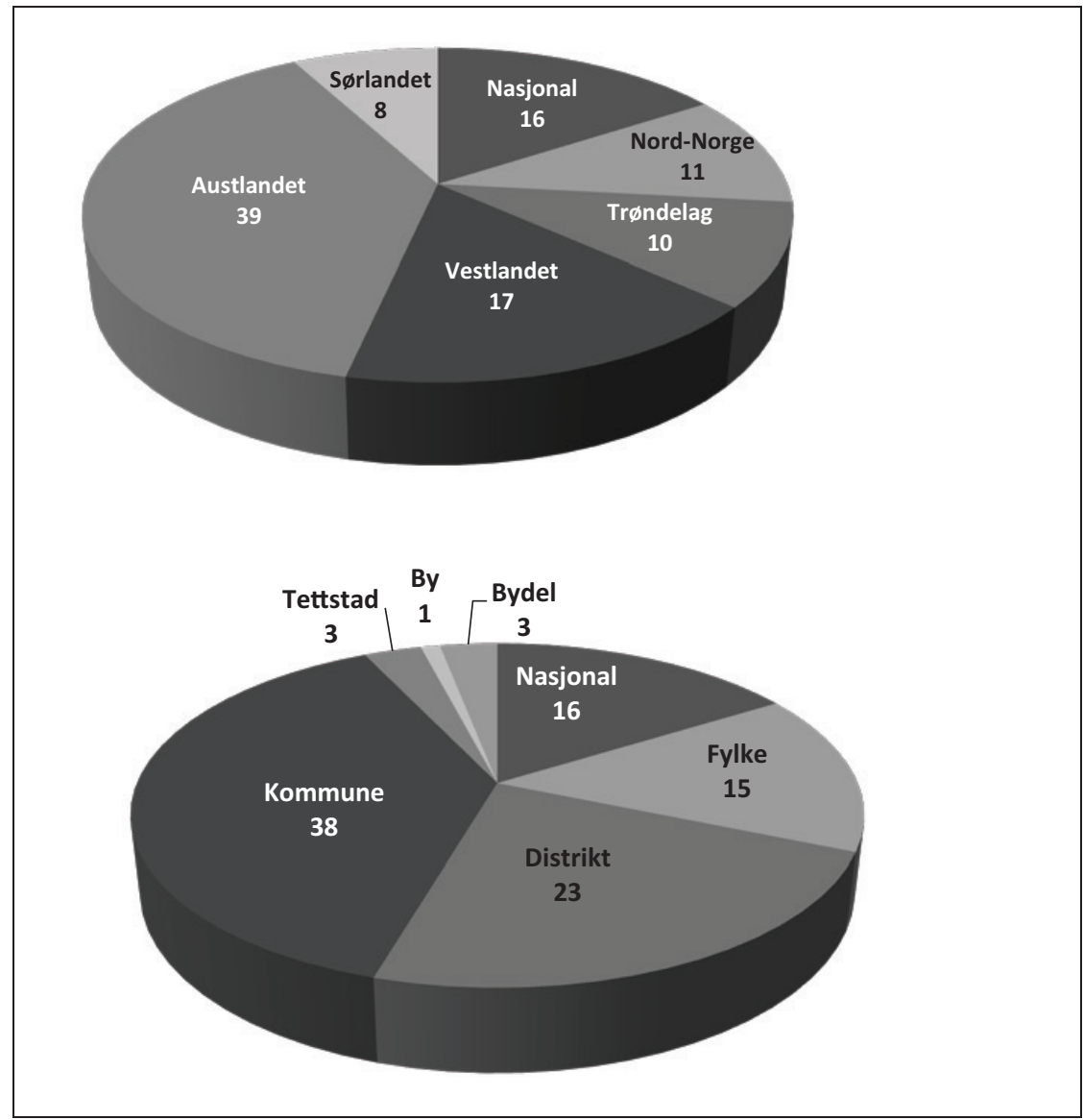

Figur 3: Fordeling av Facebook-grupper per landsdel og fordeling på geografisk nedslagsfelt. 2016. Prosent $(N=147)$.

trolig var det derfor det var kommunegrenser som definerte det geografiske nedslagsfeltet og konteksten for mange av Facebook-gruppene også.

Analysene viser her at sosiale medier var med på å spre oppmerksomhet og engasjement for flyktninger over store geografiske avstander $\mathrm{i}$ Norge på relativt kort tid. Dette illustrerer hvordan sosiale medier utgjør en ny infrastruktur for mobilisering og organisering av frivillig hjelp og bistand på relativt kort tid og utenom etablerte organisasjons- og mediestrukturer. Samtidig er engasjement ofte lokalt basert og blir initiert når det oppstår hjelpebehov lokalt i norske kommuner. 


\section{Sosiale medier og flyktningengasjementet generelt}

Som dokumentert av Audun Fladmoe i kapittel 5, viser data fra Medborgerpanelet at om lag en av tre nordmenn (34 prosent) bidro i form av donasjoner av penger, mat, klær eller utstyr (31 prosent), eller i form av frivillig innsats (8 prosent). Videre bidro 11 prosent av disse gjennom et nytt initiativ eller en organisasjon, slik Refugees Welcome er et eksempel på, mens storparten ( 57 prosent) bidro gjennom en tradisjonell frivillig organisasjon. Hjelpebidragene gjennom de nyopprettede initiativene var altså i mindretall sammenlignet med bidrag gjennom mer tradisjonelle kanaler.

For å undersøke i hvilken grad hjelpebidragene i de nye initiativene hadde sammenheng med andre hjelpepraksiser, eller om de var fraskilte, har jeg undersøkt om de ulike hjelpepraksisene ble gjort i kombinasjoner med hverandre. Her viser data (figur 4 nedenfor) at av de som bidro for et nytt initiativ, var det bare 5 prosent som bidro for et nytt initiativ alene. 4 prosent bidro både for et nytt initiativ og for en tradisjonell frivillig organisasjon, 1 prosent bidro både for et nytt initiativ og på egen hånd, og under 1 prosent bidro for et nytt initiativ og for et offentlig eller privat initiativ, eller for et asylmottak. Omtrent halvparten av de som bidro med hjelp til flyktninger gjennom et nytt initiativ, bidro altså i kombinasjon

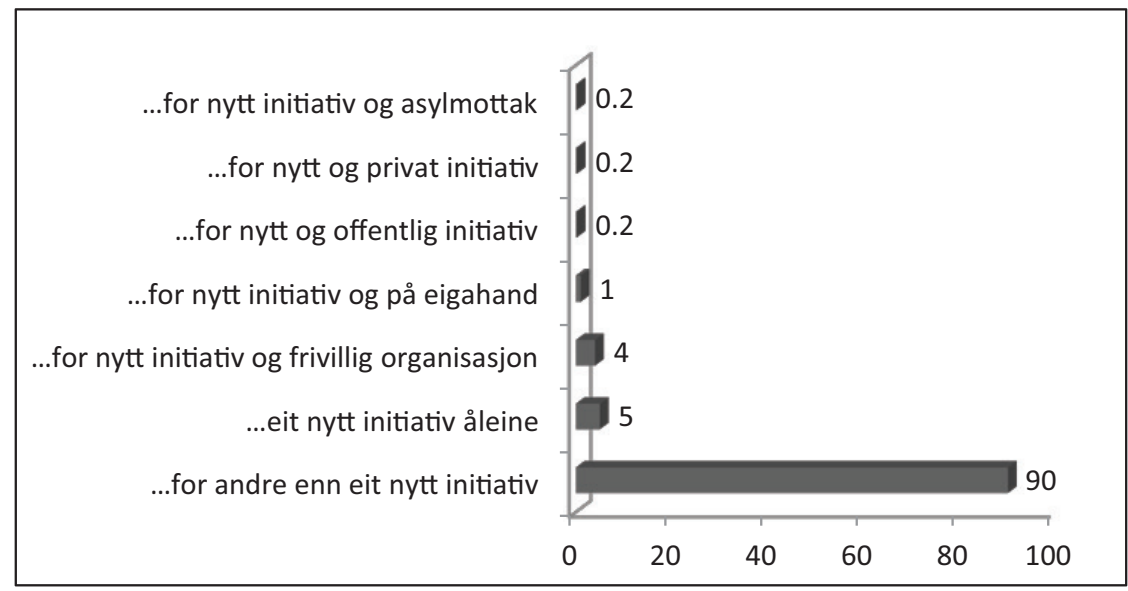

Figur 4: Type initiativ man bidro til flyktningsituasjonen gjennom $(N=434)$. 
med en annen form for hjelpepraksis. Dette viser at de nye praksisformene som er fasilitert av sosiale medier, gjerne er kombinert med andre og mer etablerte praksisformer, samtidig som de fungerer som et supplement til etablerte hjelpepraksiser, om enn i avgrenset omfang.

Som jeg har diskutert ovenfor, kan handlinger og praksisformer i sosiale medier spre seg raskt og langt på grunn av nettverksstrukturen, og derigjennom spre informasjon og potensielt mobilisere til handling. Sosiale medier kan på denne måten ha viktige funksjoner som informasjons- og mobiliseringskanaler for handling. Dette vises også i data fra Medborgerpanelet (figur 5), der 26 prosent av de som bidro i flyktningsituasjonen, fikk informasjon om mulighet til å bidra gjennom sosiale medier (Facebook + Andre sosiale medier), og der Facebook var den tredje viktigste informasjonskanalen (24 prosent) totalt sett. Som vist av Fladmoe et al. (2016) var også sosiale medier særskilt viktige som informasjonskanaler for dem som bidro for slike sosiale medier-baserte initiativ, der 67 prosent fikk informasjonen gjennom sosiale medier. Totalt sett og som vist i figur 5 var likevel etablerte former for annonsering og medieomtale i aviser, nettaviser, tv eller radio (36 prosent) og gjennom etablerte frivillige organisasjoner ( 28 prosent) de viktigste informasjonskanalene for dem som bidro.

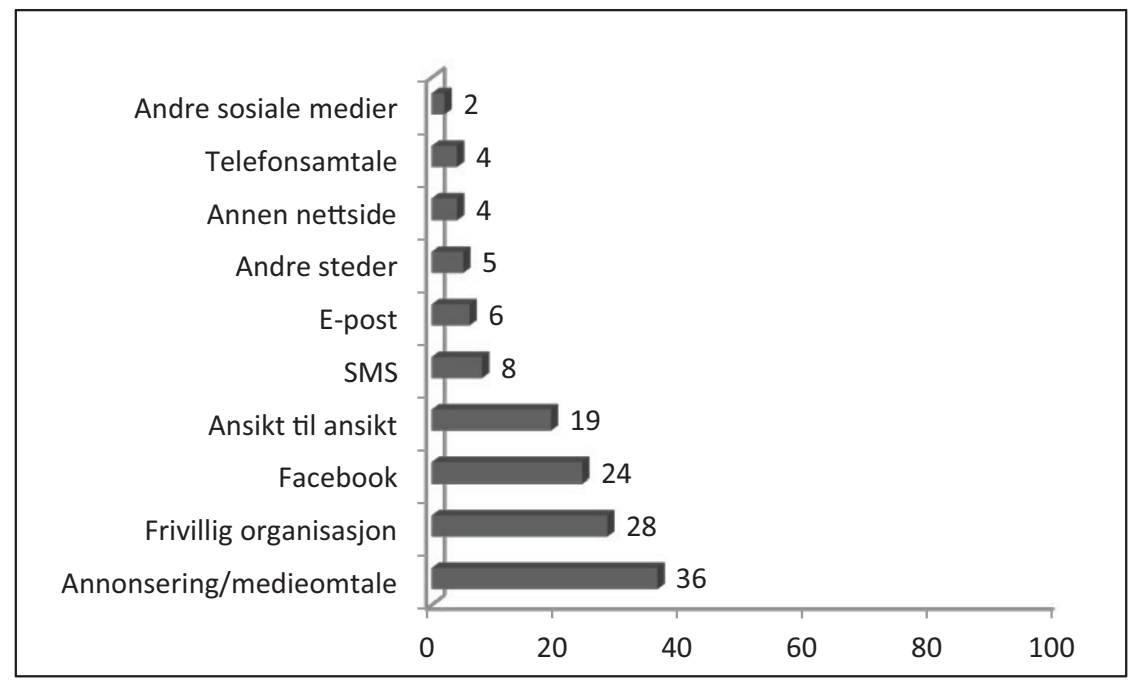

Figur 5: Kilde til informasjon om mulighet for å bidra som frivillig. Flere svar mulig. Prosent $(N=459)$. 


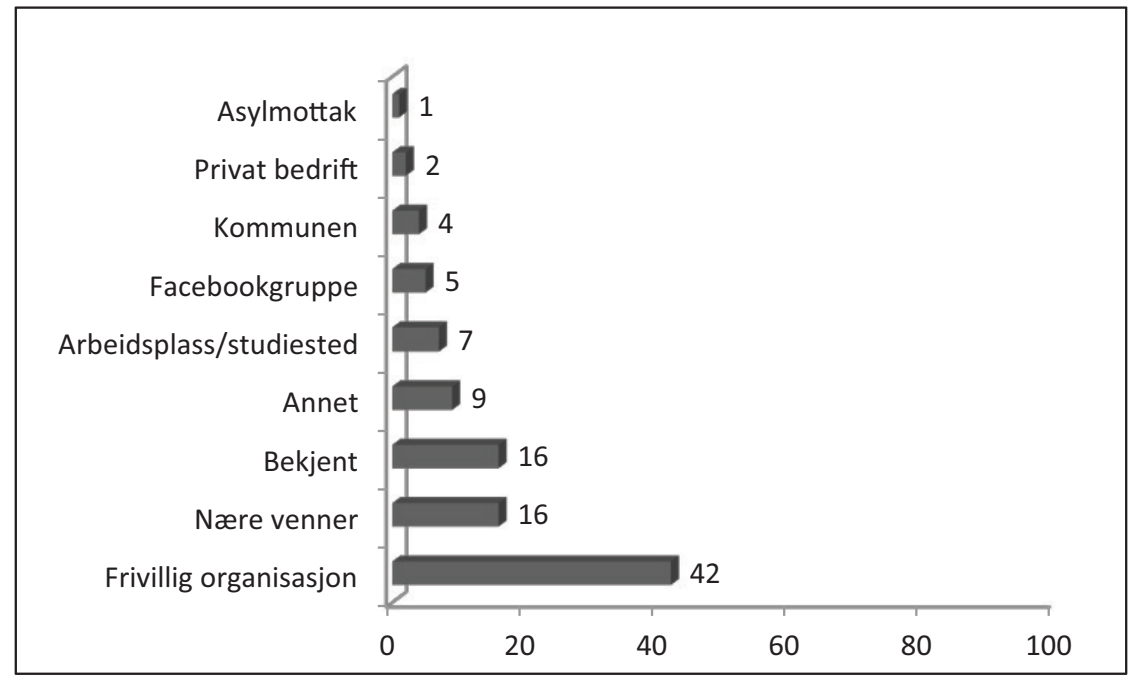

Figur 6: Invitert til å bidra som frivillig av andre. Flere svar mulig. Prosent $(N=243)$.

Blant de som ble mobilisert til handling gjennom direkte invitasjoner, hadde frivillige organisasjoner også en dominerende rolle, der 42 prosent oppgav å bli invitert av frivillige organisasjoner (se figur 6). Tilsvarende mobiliserte Facebook-grupper 5 prosent av bidragene gjennom direkte invitasjoner. Igjen ser vi at mer tradisjonelle praksisformer dominerer over de sosiale medier-baserte praksisformene.

Når vi analyserer surveydata om den norske hjelpeinnsatsen under flyktningsituasjonen, ser vi altså her at sosiale medier supplerer tradisjonelle kanaler for informasjon om mulighet for hjelpebidrag til flyktninger, i særlig grad for de som bidro gjennom nye sosiale medier-baserte initiativ. Men vi ser likevel at sosiale medier plasserer seg bak de mer tradisjonelle kanalene i omfang totalt sett. Også som mobilisatorer for hjelpebidrag gjennom direkte invitasjoner var det de frivillige organisasjonene som dominerte, mens Facebook-grupper stod for et mindretall av de mobiliserte bidragene. Her viser også Fladmoe (se kapittel 5) at et stort flertall av de frivillige under flyktningsituasjonen var knyttet til frivillige organisasjoner fra før gjennom frivillig arbeid. Dette tyder på at etablerte frivillige organisasjoner med større hell kan mobiliseres til hjelpebidrag gjennom egne nettverk av frivillige og medlemmer, mens invitasjoner til hjelpebidrag gjennom Facebook-grupper har et mye mindre omfang på tross av den store og raske utbredelsen som Facebook-engasjementet 
hadde, og på tross av de store medlemstallene som flere av hjelpegruppene på Facebook hadde. Dette kan tyde på at mobiliseringseffekten til Facebook-grupper er begrenset sammenlignet med effekten av at frivillige organisasjoner mobiliserer sine egne nettverk av frivillige.

\section{Avsluttende diskusjon: Sosiale medier-basert flyktninghjelp som supplerende praksisform}

Ut fra medieoppmerksomheten som de nye sosiale medier-baserte hjelpeinitiativene for flyktningene fikk i 2015, kunne man få inntrykk av at det var særlig takket være Facebook at mange bidro som frivillige eller med donasjoner. I litteraturen omkring sosiale medier og samfunnsengasjement har det blitt hevdet at sosiale medier, med sitt mangfold av handlingsmuligheter (Boyd, 2007), har potensial til å gjøre etablerte organisasjoner mindre viktige ettersom de på samme tid kan fungere som infrastruktur for både kommunikasjon og organisering av kollektiv handling (Shirky, 2008; Bennet \& Segerberg, 2013). På denne måten kan sosiale medier være med på endre måtene vi engasjerer oss som frivillige på og hvordan vi organiserer kollektiv handling i dag.

Med et mediepraksisperspektiv på sosiale medier og med data på både Facebook-engasjement og generelt frivillig engasjement har jeg undersøkt fremveksten av sosiale medie-baserte hjelpebidrag som vokste frem under flyktningsituasjonen i 2015, og hvordan disse var knyttet til andre engasjementsformer. Mine analyser av data om hjelpegrupper på Facebook viser her at Facebook var med på å spre oppmerksomhet og engasjement for flyktningene over hele Norge på relativt kort tid. Mange hjelpegrupper ble opprettet for å bistå flyktninger, flere av dem med svært mange medlemmer, og hjelpegruppene var ofte rettet inn mot kommuner som fokusområde for hjelpebidragene. Facebook utgjorde med dette en egen infrastruktur for mobilisering og organisering av frivillig hjelp og bistand under flyktningsituasjonen. I disse gruppene var en ikke avhengig av etablerte organisasjonsstrukturer eller andre mediekanaler for å mobilisere engasjement. Enkeltindivider eller uformelle grupper kunne her raskt mobilisere til handling. På denne måten har sosiale medier desentralisert evnen til å mobilisere og organisere kollektiv handling. 
Men for å vurdere de videre samfunnsimplikasjonene av sosiale medier er det viktig å kunne sammenligne praksisformer i sosiale medier med tilsvarende praksisformer utenom sosiale medier. En mediesosiologisk og praksisorientert tilnærming kan hjelpe oss med dette ved å ta hensyn til medienes innvevning i samfunnet - et kritisk perspektiv som ser mediepraksiser i sammenheng med andre praksisformer. Min tilnærming til dette har vært å sammenligne det sosiale medier-baserte flyktningengasjementet med andre og mer etablerte former for mobilisering, bistand og hjelp, gjennom frivillige organisasjoner og etablerte mediekanaler. Denne analysen, sammen med analysene til Fladmoe i kapittel 5, viser at hjelpebidragene gjennom nye sosiale medier-baserte initiativ var relativt få i omfang sammenlignet med for eksempel hjelpebidrag gjennom tradisjonelle frivillige organisasjoner. Bidragene som ble gjort gjennom sosiale medier-baserte initiativ, var også ofte kombinert med andre former for hjelp. Også når det gjelder sosiale medier som informasjons- og mobiliseringskanaler, var annonsering og omtale i tradisjonelle mediekanaler og informasjon fra frivillige organisasjoner viktigere totalt sett.

Dette betyr ikke at omfanget av og innsatsen i de nye sosiale medierbaserte initiativene ikke var viktige. Tvert imot fungerte de som viktige supplement til de eksisterende strukturene, der de i særlig grad kunne bidra med hurtig, fleksibel og langtrekkende mobilisering av engasjement. Som vi kan lese av intervjustudien til Synne Sætrang i kapittel 6, ble for eksempel dette trukket frem som sentrale elementer blant initiativtakerne og frivillige i Refugees Welcome to Norway, der sosiale medier gav mulighet til å mobilisere hjelp raskt til flyktningene i den raskt oppståtte situasjonen ved Politiets utlendingsenhet på Tøyen i august 2015 . Når man her ser ulike studier med ulike tilnærminger og ulike datakilder i sammenheng, får man et mer utfyllende og nyansert bilde av implikasjonene av sosiale medier under flyktningsituasjonen.

Metode-, data- og studiemangfold vil jeg også hevde er fordelaktige strategier mer generelt for å forstå de samfunnsmessige implikasjonene av sosiale medier og for mobilisering og organisering av samfunnsengasjement. Min egen og andre studier av flyktningengasjementet i 2015 støtter her tidligere forskning, som finner at sosiale medier fungerer som viktige supplement til, men ikke som direkte overtagere for etablerte 
infrastrukturer for mobilisering og organisering av frivillig engasjement (Enjolras mfl., 2013, Eimhjellen \& Ljunggren, 2017; Eimhjellen, 2018; Eimhjellen mfl., 2018). Sosiale medier er på denne måten også en del av utviklingen mot mer direkte, hurtige og fleksible former for frivillig engasjement i Norge, samtidig som det eksisterende organisasjonslivet med sterke historiske tradisjoner utgjør de grunnleggende infrastrukturene for mobilisering og organisering av denne formen for samfunnsengasjement (Eimhjellen mfl., 2018; Enjolras \& Strømsnes, 2018).

I andre samfunn som har andre tradisjoner, strukturer og institusjonell sammensetning i mediesfæren og i frivillig sektor, kan dette selvsagt fortone seg annerledes, og sosiale medier kan ha andre funksjoner og effekter. Nettopp av den grunn er det derfor viktig å kunne studere effekter av medier og mediepraksiser empirisk i den samfunnskonteksten de blir brukt og utøvd i, og i sammenheng med omliggende strukturer, kulturer og praksiser.

\section{Referanser}

Aoir (2012). Association of Internet Researchers. Ethical Decision Making and Internet Research: Recommendations from the AoIR Ethics Working Committee (Version 2.0)

Bennet, L., \& Segerberg A. (2013): “The logic of connective action”. Information, Communication and Society, 15 (5): 739-768.

Boulianne, S. (2009). Does Internet Use Affect Engagement? A Meta-Analysis of Research. Political Communications, 26(2), 193-211.

Boulianne, S. (2015). Social media use and participation: a metaanalysis of current research. Information, Communication \& Society, 18 (5): 524-538.

Boyd, D. (2011). Social network sites as networked publics. Affordances, dynamics and implications. I Z. Papacharissi (Red.). A networked self. Identity, community and culture on social network sites. New York: Routledge.

Boyd, D., \& Ellison, N.B. (2007). Social network sites: Definition, history, and scholarship. Journal of Computer-Mediated Communication, 13 (1): 210-230.

Couldry, N. (2012). Media, Society, World: Social Theory and Digital Media Practice. Malden, MA: Polity Press, 2012

Conroy, M., Feezell, J. T., \& Guerrero, M. (2012). Facebook and political engagement: A study of online political group membership and offline political engagement. Computers in Human Behavior, 28(5): 1535-1546. 
Eimhjellen, I., \& Ljunggren, J. (2017) Kollektiv handling i digitale medier. Nye digitale skiller? Rapport 2017-3. Senter for forskning på sivilsamfunn og frivillig sektor.

Eimhjellen, I. (2018) New forms of civic participation. Implications of social media on civic participation and organization in Scandinavia. I L.S. Henriksen, K. Strømsnes, \& L. Svedberd (Red.) Civic engagement in Scandinavia. Volunteering, Informal help and Giving in Denmark, Norway and Sweden Springer.

Eimhjellen, I., Steen-Johnsen, K., Folkestad, B., \& Ødegård, G. (2018). Changing patterns of volunteering and participation. I B. Enjolras \& K. Strømsnes (Red.), Scandinavian Civil Society and Social Transformations: The Case of Norway: Springer.

Ekman, M. (2018). Anti-refugee Mobilization in Social Media: The Case of Soldiers of Odin. Social Media + Society. 2018;4(1):2056305118764431.

Europaparlamentet (2015). European Parliament Eurobarometer 84.1: Parlemeter 2015 Part I, The main challenges for the EU, migration, and the economic and social situation. Tilgjengelig på http://www.europarl.europa.eu/pdf/ eurobarometre/2015/2015parlemeter/eb84_1_synthese_analytique_partie_1_ migration_en.pdf

Enjolras, B., \& Strømsnes, K. (2018). Scandinavian Civil Society and Social Transformations: The Case of Norway: Springer.

Enjolras, B., Karlsen, R., Steen-Johnsen, K., \& Wollebæk, D. (2013): Liker - Liker ikke: Sosiale medier samfunnsengasjement og offentlighet. Oslo: CappelenDam.

Fladmoe, A., Sætrang, S., Eimhjellen, I., Steen-Johnsen, K., \& Enjolras, B. (2016): Nordmenns bidrag i flyktningsituasjonen 2015/2016. Oslo: Senter for forskning på sivilsamfunn og frivillig sektor.

Henriksen, L.S., Strømsnes, K., og Svedberg L. (2018) Civic engagement in Scandinavia. Volunteering, Informal help and Giving in Denmark, Norway and Sweden. Springer.

Kaun, A., \& Uldam, J. (2017). Volunteering is like any other business: Civic participation and social media. New media and society (online first), 1-22.

Lutz, C., Hoffman, C. P., \& Meckel, M. (2014). Beyond just politics: A systematic literature review of online participation. First Monday Peer-revieew journal of the internet, 19 (7).

Music, M.A., \& Wilson, J. (2008). Volunteers a social profile. Indiana University Press.

NESH (2014). Den nasjonale forskningsetiske komitè for samfunnsvitenskap og humaniora. Etiske retningslinjer for forskning på internett.

Sassen S. (2002). Towards a sociology of information technology. Current Sociology 50: $365-388$.

Shirky, C. (2008). Here comes everybody. The power of organizing without organizations. New York: Penguin Books. 
SSB (2016). Dette er Norge 2016. Hva tallene forteller. Oslo/Kongsvinger: Statistisk sentralbyrå.

Sætrang, S. (2016). Ikke bare en Facebook-gruppe. En casestudie av Refugees Welcome-nettverket i Norge. Oslo: Senter for forskning på sivilsamfunn og frivillig sektor.

Thorleifsson, C. (2016). Fokus: Migrasjonskrisen. Høyreradikale responser. Internasjonal Politikk, 74(2). doi:https://doi.org/10.17585/ip.v74.457

UDI (2016). Beboere i asylmottak etter fylke og måned (2015). https://www.udi.no/ statistikk-og-analyse/statistikk/mottaksbefolkning-antall-beboere-i-mottak-etterfylke-og-maned-2015/. [05.12.2016

Verba, S., Nie, N.H., \& Kim, J-O. (1978). Participation and Political Equality: A Seven-Nation Comparison. Chicago: Chicago University Press.

Vitak, J., Zube, P., Smock, A., Carr, C., T., Ellison, N.B., \& Lampe, C. (2011). It's complicated: Facebook users' political participation in the 2008 election, Cyberpsychology, Behavior, and Social Networking. 14(3). 107-114.

Westrum R. (1991). Technologies \& society. The shaping of people and things, Belmont California: Wadsworth Publishing Company.

Wollebæk, D., \& Selle, P. (2002). Det nye organisasjonssamfunnet. Demokrati i omforming. Bergen: Fagbokforlaget.

de Zúñiga, H.G.,Puig-i-Abril, E., \& Rojas, H.(2009). Weblogs, traditional sources online and political participation: An assessment of how the Internet is changing the political environment. New Media and Society 11(4) 553-574.

de Zúñiga, H.G., Veenstra, A., Vraga, E., \& Shah, D. (2010). Digital democracy: Reimagining pathways to political participation. Journal of Information Technology \& Politics7(1) 36-51.

Åsen, B., Haug, M., \& Lynnebakke, B. (2017). Frivillighetens ressurser langs asylsøkerkjeden. NIBR-rapport 2017:3. 


\title{
Refleksiv institusjonalisering. Nytt frivillig engasjement i brytningen mellom endring og stabilitet
}

\author{
Ivar Eimhjellen
}

NORCE

\begin{abstract}
In this chapter I explore how collective action is initiated, mobilized and organized in light of trends of more individualized and reflexive forms of volunteering in Norway. By conducting a qualitative case-study of the climate-based Transition-initiative in Bergen, Norway, I have illustrated how general trends in volunteering are manifested on the local level, shaped by institutionalized frames of action, but also open for interpretative flexibility. Adaptation to reflexive and self-oriented volunteers in Transition entailed a decentralized, informal, flexible, network- and neighborhood-based mode of organizing collective action, focusing on the volunteers' and participants' personal interests and resources and the surrounding social and physical infrastructure. A prerequisite behind this organizational form were paid positions for coordinating, administrating and "nudging" volunteers and their activities to fit the organization's objective. A certain degree of formalization and institutionalization due to organizational growth has also been necessary over the course of the years. Contradicting expectations from the theory of reflexive volunteering of attenuated organizational identities and social bonds in organizations, the Transition-initiative indicated the opposite, aiming at building a community-based organization. Albeit being locally focused, the initiative was inspired by global issues and is also connected to the international Transition movement, and is also a political actor on the national level. In order to analytically describe the Transition-initiative I propose the concept of reflexive institutionalization, referring to an organizational adaptation to reflexive forms of volunteering simultaneous to an inevitable process of institutionalizing some form of organizational structure if a sustainable (network-) organization is to be built.
\end{abstract}

Keywords: volunteering, organization, reflexive institutionalization, formalization, grassroots

Sitering av denne artikkelen: Eimhjellen, I. (2018). Refleksiv institusjonalisering. Nytt frivillig engasjement i brytningen mellom endring og stabilitet. I B. Enjolras \& I. Eimhjellen (Red.), Fra kollektiv til konnektiv handling? Nye former for samfunnsengasjement og kollektiv handling i Norge (s. 211-234). Oslo: Cappelen Damm Akademisk. https://doi.org/10.23865/noasp.45.ch8 Lisens: CC BY-NC 4.0 


\section{Innledning}

Med utgangspunkt i samfunnsendringer knyttet til de overordnede prosessene globalisering, digitalisering og individualisering som er i fokus $\mathrm{i}$ denne boken, er det interessant å undersøke hvordan dette har fått konsekvenser for måten norsk kollektivt engasjement på grasrota kan oppstå og utvikles på. Hvilken innvirkning og konkrete uttrykk kan de større endringsprosessene få for hvordan nordmenn engasjeres og organiseres til kollektiv handling på? Ved hjelp av en studie av grasrotbevegelsen Bærekraftige liv i Bergen skal jeg i dette kapitlet gi noen illustrasjoner på hvordan grasrotmobilisering og organisering kan manifestere seg på lokalt nivå. Hovedproblemstillingen er hvordan kollektiv handling oppstår, mobiliseres og organiseres lokalt i lys av endrings- og utviklingstrekk i norsk frivillighet og i særlig grad knyttet opp mot såkalt individualiserte og refleksive former for frivillig engasjement. Ser vi en fremvekst av helt nye former for organisering av kollektiv handling i Norge, eller institusjonaliseres nytt engasjement inn i etablerte strukturer, logikker og tradisjoner for frivillig engasjement? Som et svar på dette spørsmålet avslutter jeg kapitlet med et fremlegg og diskusjon av begrepet refleksiv institusjonalisering, som er ment å beskrive disse utviklingsprosessene $\mathrm{i}$ organisering av grasrotengasjement i Norge.

\section{Globale endringsprosesser på lokalnivå}

Som drøftet i innledningskapitlet i denne boken blir det moderne vestlige samfunn ofte beskrevet som å være i en stadig globaliserings-, individualiserings- og digitaliseringsprosess. På denne måten kan globale tema og hendelser, individsentrerte verdier og valgfrihet samt digital kommunikasjonsteknologi påvirke motivasjon for deltakelse i og evner til å mobilisere og organisere kollektiv handling. Et perspektiv på hvordan globale endringsprosesser har påvirket frivillig engasjement, uttrykkes blant annet gjennom begrepet og teorien om «refleksiv frivillighet» (Hustinx \& Lammertyn, 2003). Hustinx og Lammertyn (2003) hevder her at dagens frivillighet består av et større mangfold av mulige handlings-, organiserings- og motivasjonsformer enn før. Frivillig og kollektivt engasjement 
tenkes her å bli påvirket både gjennom større samfunnsstrukturelle endringer som påvirker menneskers livssituasjon (som velstand og velferd), og gjennom menneskers endrede motivasjoner, holdninger og orienteringer (Hustinx \& Lammertyn, 2003). Fortsatt finner vi tradisjonelle kollektivistiske frivillighetsformer som er basert på kollektive normer, roller og ansvar, og vi finner fortsatt varige organisasjonsmedlemskap i formelle, hierarkiske og lokalt tilknyttede organisasjoner som tilbyr faste rammer for identitetsutvikling, sosialisering og gruppefellesskap. Men det hevdes her at det nå også har vokst frem mer refleksive frivillighetsformer som tar utgangspunkt i selv-orienterte (men likevel altruistiske) individer som søker å oppnå mer instrumentelle mål (Hustinx \& Lammertyn, 2003). Deltakelse og engasjement blir mer uregelmessig og begrenset i tid og rom, og med løsere bånd til organisasjoner, og de frivillige vil i økende grad spre sitt engasjement på flere organisasjoner som kan fylle forskjellige behov hos de frivillige.

Ifølge teorien om refleksiv frivillighet vil dagens frivillige oftere søke seg til mer uformelle, selv-organiserte, desentraliserte og prosjektbaserte initiativ, ofte på grasrotnivået med få eller ingen tilknytninger til høyere organisasjonsnivå. Utviklingen i digital kommunikasjonsteknologi har i stor grad muliggjort mer selv-organiserte og desentraliserte initiativ og organisasjonsstrukturer. I organisasjonsteorien kan dette også fanges inn under begrepet «nettverksorganisering» (Powell, 1990), der kollektiv handling er organisert gjennom horisontalt differensierte oppgaver, prosjekter eller aktiviteter heller enn ved hjelp av formelle hierarkisk kontrollerte organisasjoner. Som nevnt i introduksjonskapitlet kan også nye organisasjoner kombinere både hierarkiske og heterarkiske (nettverksbaserte) kjennetegn (Kontopoulos, 1993). Slik nettverksorganisering kan her tenkes å være mer tilpasset den refleksive frivillige enn hva den klassiske hierarkiorganisasjonen er. Samtidig er det i dag også mange frivillige organisasjoner som går bort fra en medlemsbasert organisasjonsmodell med demokratiske strukturer og heller etablerer mer sentraliserte og profesjonaliserte organisasjoner, som i større grad er rettet mot å utføre tjenester (Hustinx \& Lammertyn, 2003). En konsekvens av denne utviklingen er ifølge teorien at frivillige organisasjoner som sådan i mindre grad fungerer som arenaer for sosialisering og identitetsutvikling mellom 
medlemmer basert på geografisk nærhet eller gruppekultur. Organisasjonene blir i økende grad erstattet av mer løst organiserte nettverk hjulpet av digital kommunikasjonsteknologi på den ene siden og av sentraliserte og profesjonaliserte organisasjoner på den andre siden. De selv-refleksive frivillige vil søke seg både til de mer profesjonelle organisasjonene der de kan utføre spesifiserte og konkrete arbeidsoppgaver på en effektiv måte, og til de mer fleksible, uformelle og nettverksbaserte organisasjonene som kan tilfredsstille mer umiddelbare ønsker om engasjement. (Hustinx \& Lammertyn, 2003).

Fra tidligere empirisk forskning i Norge har vi sett en del utviklingstrekk som kan peke i retning av mer refleksiv og individualisert frivillighet også i Norge (Eimhjellen, Steen-Johnsen, Folkestad \& Ødegård, 2018). Selve nivået av frivillig innsats for organisasjoner er stabilt høyt med over 60 prosent av befolkningen som har gjort en form for frivillig innsats siste året (Folkestad et al., 2015; Fladmoe et al., 2018), men vi ser tegn til at formen på frivillig innsats endrer seg. Det er færre frivillige som er formelt knyttet til en organisasjon gjennom medlemskap, de frivillige sprer sitt engasjement på flere organisasjoner og arenaer, og den frivillige innsatsen er i økende grad tidsbegrenset for eksempel knyttet til et enkelt arrangement (Eimhjellen et al., 2018). Også motivasjonen for frivillig arbeid har endret seg der selv-realisering og egen-orientering er blitt viktigere enn før (Wollebæk, Fladmoe \& Sætrang, 2015). Dette kan tolkes som uttrykk for en mer refleksiv og individualisert frivillighet i Norge, der frivillige i økende grad er opptatt av å realisere egne målsettinger og identiteter gjennom sitt frivillige engasjement, og der de mer strategisk velger ut de organisasjonene og arenaene de vil engasjerer seg på, og som vil kunne oppfylle de personlige målsettingene, gjerne uavhengig av geografisk og lokal kontekst (Eimhjellen et al., 2018). Også på organisasjonsnivå har norsk frivillighet endret seg. Fra den tradisjonelle hierarkiske organisasjonsstrukturen med lokallag, regionallag og et nasjonalt nivå har utviklingen siden 80 -tallet vist en nedgang i antall lokallag samtidig som antall nasjonale organisasjoner uten regionale eller lokale enheter har økt (Arnesen et al., 2016, s. 28). Vi ser her en todeling av organisasjonssamfunnet med flere frittstående lokale organisasjoner uten koblinger til høyere organisasjonsnivå og flere nasjonale organisasjoner uten 
lokallag (Selle \& Øymyr, 1995; Wollebæk \& Selle, 2002; Arnesen et al., 2016). Det skjer også en profesjonalisering av organisasjonslivet, spesielt på det nasjonale nivået, der andelen betalte ansatte (heltid/deltid) er økende (Arnesen et al., 2016). Disse betalte ansatte har for eksempel i oppgave å administrere, koordinere og legge bedre til rette for frivillig arbeid, noe som potensielt kan utløse mer engasjement fra de frivillige som kvier seg for organisasjonsansvar og plikter, og som heller kan gå rett på konkrete oppgaver de er motivert for (Arnesen et al., 2016).

\section{Organisering og institusjonalisering}

Selv om det gjennom mange års forskning har blitt pekt på endringer i sivil- og organisasjonssamfunnet i Norge (Wollebæk, Selle \& Lorentzen, 200o; Wollebæk \& Selle, 2002), finnes det også flere tegn til stabilitet i de grunnleggende rammene for frivilligheten. Som nevnt er for eksempel nivået av frivillig innsats rekordhøyt, og tradisjonelle frivillige organisasjoner er fortsatt de viktigste arenaene for slikt engasjement (Enjolras \& Strømsnes, 2018). For å forstå og forklare hvorfor ting ikke nødvendigvis endres like raskt eller i like stor grad som endringsteorier tilsier, kan vi dra nytte av et grunnleggende sosialkonstruktivistisk eller strukturasjonsperspektiv på samfunnsendring (Giddens, 1976; Giddens, 1979; Giddens, 1984). I et slikt perspektiv forenes forklaringer på hvordan sosiale strukturer både begrenser og legger til rette for menneskelig handling, samtidig som man anerkjenner at disse sosiale strukturene på samme tid er resultatet av tidligere menneskelig handling. Gjennom gjentatte handlinger og interaksjoner blir sosiale mønstre for handling utformet, og over tid blir disse mønstrene til institusjonaliserte rammer for handling som utgjør de grunnleggende strukturene i de sosiale systemene, som igjen er med på å forme menneskers handlinger. Dette innebærer at større sosiale endringer og også endringer i institusjonelle felt som sivilsamfunnet vil ta tid og gjerne skje i en vekselvirking mellom eksterne impulser og variasjoner i fortolkinger, praksiser og handlinger (Mahoney \& Thelen, 2010). På denne måten er sosial og institusjonell endring og stabilitet sammenvevd, der institusjoner både endres og bevares gjennom menneskelig fortolkning og praksis. 
Formelle frivillige organisasjoner er altså et helt sentralt element i det norske sivilsamfunnet og for koordinering og forvaltning av kollektiv handling og frivillig engasjement. I et slikt perspektiv er det interessant å undersøke hvordan nye kollektive bevegelser etableres og tar form; i hvilken grad de påvirkes av de større samfunnsendringene knyttet til globalisering, individualisering og digitalisering; og i hvilken grad de formes av de etablerte logikkene, normene og reglene for koordinering og forvaltning av kollektiv handling og frivillig engasjement. I forlengelsen av dette kan vi bruke et institusjonaliseringsperspektiv for å undersøke fremvekst, utvikling og organisering av engasjement. Fra tidligere er det for eksempel gjort flere observasjoner av nye spontane og løst organiserte sosiale bevegelser som over tid utvikler seg til hierarkiske og byråkratiske organisasjoner, der organisering og styring blir sentrale element (Blumer, 1946; Brand, 1990; Downs, 1972; Michels, 1962 [1915]; Tarrow, 2005; Tilly, 1978, Weber, 1993). Kollektive bevegelser går ofte gjennom en slik institusjonaliseringsprosess der de med økende alder tenderer mot å utvikle mer etablerte og rigide organisasjonsstrukturer, regler og normer for handling (Stinchcombe, 1965). Kollektive bevegelser, som gjerne manifesteres i konkrete organisasjoner, blir etter hvert gjerne formet av de eksisterende normene og praksisene for organisering som omkranser bevegelsen på etableringstidspunktet. Samtidig blir organisasjoner ofte mindre tilpasningsdyktige til nye endringer i omgivelsene sine etter som årene går (Stinchcombe, 1965; Hannan \& Freeman, 1984) - organisasjonene institusjonaliseres.

For eksempel ble de nye sosiale bevegelsene fra 1960- og 70-tallet, inkludert miljøbevegelsen, sett på som iboende anti-byråkratiske og anti-hierarkiske - selve antitesen til institusjonaliserte organisasjoner (Melucci, 1985; Offe, 1985; Touraine, 1981). Likevel ser de samme sosiale bevegelsene ut til å ha blitt institusjonaliserte, inkorporerte og til og med koopterte av det etablerte styringssystemet (Eder, 1996; Giugni \& Passy, 1998; Hajer, 1995; Jamison, 1996; Meyer \& Tarrow, 1998; Rucht et al., 1997; Seippel, 2001). Studier av nyere sosiale bevegelser, for eksempel bevegelsen for globalisering nedenfra (della Porta et al., 2006), kan likevel tyde på en mindre grad av, eller en annen form for institusjonalisering av sosiale bevegelser gjennom nettverksorganisering. Endringer i etablerte og 
rådende organiseringspraksiser, for eksempel knyttet til nettverksorganisering samt holdninger til organisering blant de aktive i senere tid, kan derfor ha modifisert institusjonaliseringen av nye organisasjoner som har blitt etablert i løpet av de senere år.

Med bakgrunn i de nevnte teoretiske perspektiver og begreper, samt empiriske observasjoner av endring og stabilitet i norsk organisasjonsliv, skal jeg videre beskrive og analysere fremveksten og utviklingen av det frivillige grasrotinitiativet i Bergen. Denne casen er ment å illustrere hvordan nytt lokalt engasjement og kollektiv handling kan oppstå, mobiliseres og organiseres i dag, i lys av teori om samfunns- og frivillighetsendringer, og å illustrere hvilke utfordringer som kan oppstå i møtene mellom praksis og motivasjon på individnivå og rutiner og strukturer på organisasjonsnivå. Vi skal her se hvordan nytt frivillig engasjement kan vokse frem og organiseres, og hvordan etablerte strukturer og praksiser samt endringstendenser i norsk frivillighet påvirker utviklingen. Før analysen vil jeg først gi en redegjørelse for det empiriske datagrunnlaget som ligger til grunn for analysen og for de metoder som er brukt i datainnsamlingen og i analysen.

\section{Studien av Bærekraftige liv}

Datagrunnlaget for kapitlet er en kvalitativ studie av det frivillige initiativet Bærekraftige liv i Bergen, en bevegelse som ønsker å utvikle bærekraftige lokalmiljø, naturvennlige handlinger og gode fellesskapsløsninger i møte med klimautfordringer. Jeg har her utført kvalitative forskningsintervjuer (Kvale \& Brinkman, 2015) med fem initiativtakere i tre bydelsinitiativ i Bergen. Intervjuene kan betegnes som semistrukturerte, der man følger en på forhånd formulert intervjuguide med planlagte tema og spørsmål man skal igjennom, samtidig som man har fleksibilitet til å kunne bevege seg mellom ulike tema og ulike deler av intervjuet, og til å følge opp interessante aspekter som kan dukke opp underveis. Styrken ved denne intervjuformen er at den kan fange opp variasjoner i intervjupersoners oppfatninger om et tema, og derfor også kan gi et bilde av en mangfoldig og motsetningsfull verden (Kvale \& Brinkman, 2015).

Intervjuene og studien ble utført over fire år. I 2012 intervjuet jeg de tre opprinnelige initiativtakerne bak Bærekraftige liv, og fulgte opp med 
intervju med to av dem i 2015. Slike oppfølgingsintervjuer etter en viss tid vil kunne gi en del mer kunnskap om endrings- og utviklingsprosesser enn intervjuer på ett tidspunkt. I 2015 intervjuet jeg også to initiativtakere i to nye bydelsinitiativ som hadde dukket opp siden 2012. Alle intervjuene ble gjort en-til-en, tatt opp på bånd og transkribert til tekst i etterkant. Under studien deltok jeg også i noen av aktivitetene i nabolagene og på et oppstartsmøte for et nytt bydelsinitiativ. Her skrev jeg notater i etterkant om hva som gikk for seg, og som ble sagt under hver observasjon, og mine egne refleksjoner rundt dette. Jeg samlet også inn informasjon fra flere andre nabolagsinitiativ gjennom en kort nett-survey, der jeg gjorde en kartlegging av omfang og variasjon blant deltakere og aktiviteter i syv bydelsinitiativ. I tillegg har jeg samlet inn informasjonsmateriale om initiativene fra ulike nettsider og fra profiler på sosiale medier. Samlet sett har jeg prøvd å innhente et variert datamateriale som kan gi informasjon om vurderinger og erfaringer fra initiativtakernes side om organisasjonsutvikling og om mobilisering og forvaltning av frivillig engasjement, samt data om omfanget til hele initiativet og om initiativets selvpresentasjon til omverdenen.

I analysen av datamaterialet gjorde jeg flere tematiske gjennomlesninger av transkripsjonene, der sentrale utsagn om viktige tema ble plassert i egne kategorier. Her utviklet jeg blant annet en tidslinje for fremveksten av Bærekraftige liv, der viktige utviklingstrekk som vekst i aktiviteter, grupper, hendelser og finansiering ble sortert kronologisk. Et sentralt formål har vært å kunne gi fyldige beskrivelser av utviklingen av Bærekraftige liv og å få frem de involvertes perspektiv på egne organisasjonsaktiviteter, handlinger, vurderinger og strategier. Informantene i prosjektet er anonymisert i teksten, men kan likevel identifiseres gjennom sine roller i Bærekraftige liv. Dette har informantene blitt informert om og har samtykket til. Prosjektet ble meldt inn til Norsk senter for forskningsdata (NSD).

\section{Fremveksten av et grasrotengasjement}

Bærekraftige liv (BL) ble startet av tre naboer på Landås i Bergen i 2008 for å igangsette lokale tiltak mot klimautfordringene, globalt og i Norge. Målet til Bærekraftige liv var å få til noe i handlingsrommet mellom 
individhandlinger som å brette melkekartonger, og det større nasjonale og globale politiske systemet som ble oppfattet å være preget av politisk stillstand. Initiativtakerne ønsket å gjøre miljøengasjement tilgjengelig i hverdagen til helt vanlige mennesker. I kontrast til mange tradisjonelle klima- og miljøinitiativ som bare samler likesinnede, ville initiativtakerne forene ulike typer mennesker i et lokalmiljø til samhandling for et redusert økologisk fotavtrykk og et økt fellesskap. Det overordnede målet for initiativet er å redde verden ved å starte nedenfra og å skape bærekraftige lokalsamfunn.

Det første arrangementet i initiativet var en filmvisning om bærekraftig utvikling, våren 2008. Oppmøtet på filmvisningen var begrenset, men på det andre arrangementet, et matlagingskurs påfølgende høst, deltok 90 personer, og flere nye kontakter ble etablert. Etter hvert, særlig etter en rekke av juleverkstedkvelder som ble initiert og arrangert av et ektepar i nabolaget mot slutten av 2009, tok nettverket av engasjerte personer til å vokse. Nye temagrupper ble initiert av de tre initiativtakerne, men også av de ny-engasjerte i nabolaget med utgangspunkt i deres egne personlige interesser.

Det har etter hvert oppstått et mangfold av aktiviteter under Bærekraftige liv. Disse handler blant annet om aktiviteter som temakvelder der man samler folk rundt et klimarelatert tema, gjerne med et foredrag eller en film og en diskusjon. En annen aktivitetstype er de mer praktiske aktivitetene, for eksempel vedhogst i nabolaget, parselldyrking, sykkelreparasjon og kurs i partering av lam. En tredje kategori handler mer om utvikling og planlegging av større prosjekter, som for eksempel å gjøre husene i nabolaget mer energieffektive eller å tenke ut nye transportløsninger. I denne kategorien kan man også plassere Matkollektivet, et lokalmat-distribusjonsprosjekt som kobler kunder direkte til lokale matprodusenter. Et annet prosjekt var planen om et nasjonalt kompetansesenter for lokalt klimaengasjement og lokal matproduksjon - en arena fylt med aktiviteter for lokalsamfunnet, byen og regionen: Lystgården. Initiativtakerne så her for seg å opprette en slags grønn frivillighetssentral som skulle samle kompetanse om oppstart av BL-initiativ og om bærekraftig lokalsamfunnsutvikling. I 2012 og 2013 ble også Landåskonferansen arrangert for å utvikle og gi innspill til en ny kommuneplan i Bergen. Her 
ble naboer, offentlige og private aktører og institusjoner og lokale ildsjeler invitert til idémyldring omkring utvikling av Landås som et sted for det gode og bærekraftige liv. En fjerde aktivitetstype under Bærekraftige liv handler mer om fest, moro og feiring. I 2010 ble for eksempel den første Landåsfesten arrangert. Dette har senere blitt til et årlig arrangement som samler omkring 1000 beøkende fra nabolaget og området rundt til en festdag med musikk, mat og aktiviteter med fokus på det lokale, det kortreiste og det klimavennlige.

Per 2015 kunne man telle omkring 20 temagrupper på Landås, som hver hadde sine ledere. Gruppene var i stor grad selvgående med ulik grad av aktivitet, og til sammen talte de omkring 70 aktive deltakere. Bærekraftige liv på Landås oppdaget og ble også etter hvert med i den globale Transition-Towns bevegelsen, som de delte mange av målsettingene og kjennetegn med. ${ }^{1}$ Oppmerksomheten rundt Bærekraftige liv spredte seg også videre, først i Bergen til 10 andre nabolag per 2015 og videre nasjonalt til for eksempel Trondheim, Voss og Sagene i Oslo. I 2015 kunne man telle 18 Bærekraftige liv-initiativ i Norge, pluss flere interesserte.

\section{Å finne sin organisasjonsform}

I initiativet på Landås hadde alt engasjement, arbeid og praktiske aktiviteter frem til 2010 vært gjort på frivillig basis, der de tre initiativtakerne fordelte oppgaver seg imellom og var likestilte med tanke på ansvar og ledelse. Etter hvert som flere ble engasjert og satte i gang aktiviteter, fikk de tre en mer administrativ rolle. En fjerde person ble også knyttet til det mer langsiktige og administrative arbeidet, spesielt med tanke på utvikling av web-løsninger. I 2012 fikk en av initiativtakerne også kontorplass ved Impact Hub Bergen, et kontorfellesskap for sosiale entreprenører på Bryggen i Bergen. Initiativet på Landås ble flere ganger tildelt prosjektmidler fra ulike offentlige etater og private aktører som så den potensielle samfunns- og miljøverdien de utgjorde. Basert på disse midlene ble det etter hvert opprettet to lønnede (deltid) prosjektstillinger i initiativet. ${ }^{2}$

For mer informasjon besøk https://transitionnetwork.org eller les Smith (2011).

2 Støtte kom blant annet fra Klimaseksjonen i Bergen Kommune, Fylkeskommunen, Miljøverndepartementet og Visjon Vest. 


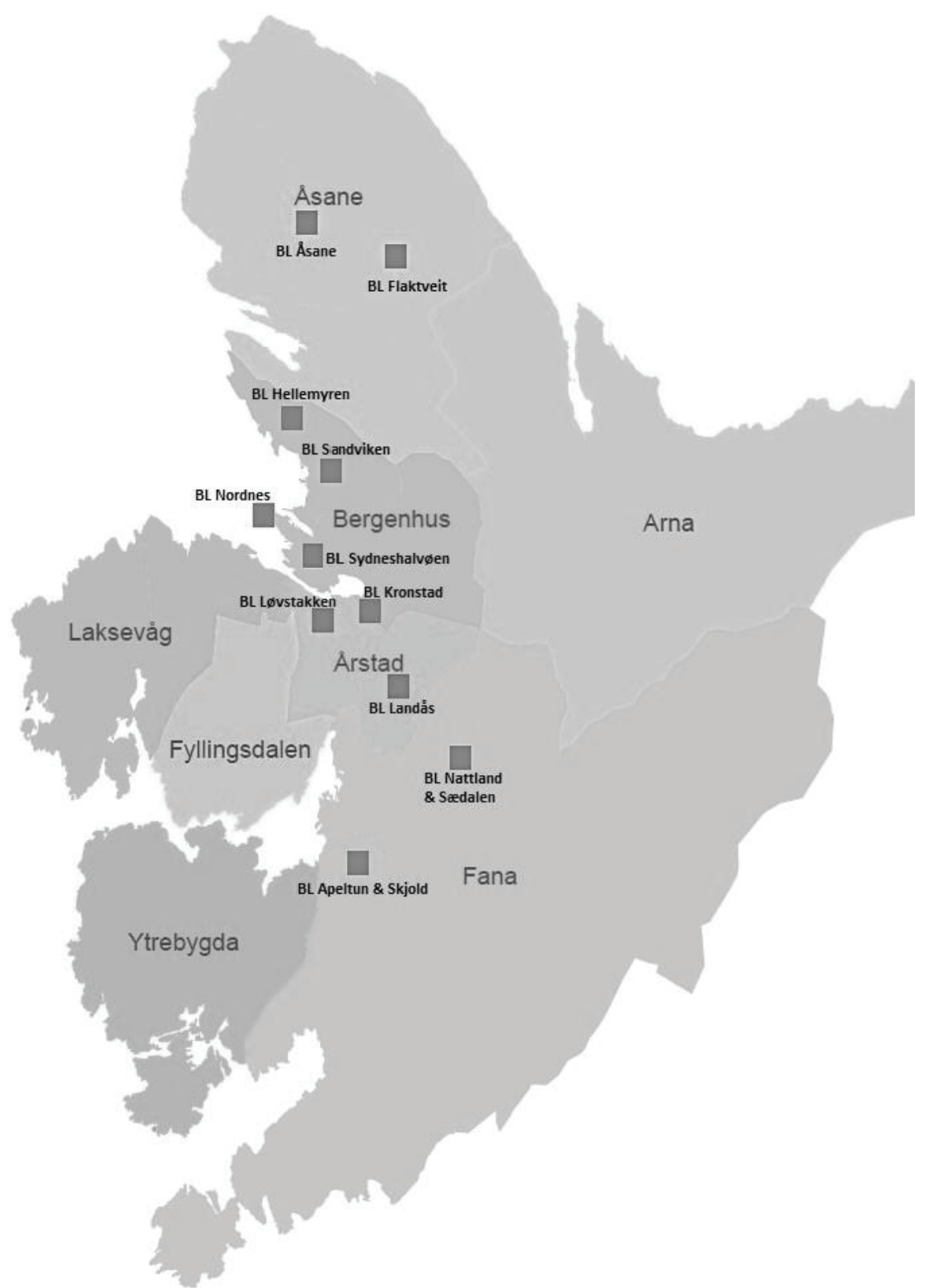

Figur 1: Bærekraftige liv-grupper i Bergen (2015)

Fra å ha vært en idé og en sped begynnelse i 2008 hadde Bærekraftige liv $\mathrm{i}$ årene som fulgte, vokst til et stort og mangefasettert nettverk av aktive, grupper og aktiviteter. Selv om noe av det administrative arbeidet rundt aktivitetene etter hvert ble mer formalisert, var målet fortsatt at 
aktivitetene og gruppene skulle være uformelle og basert på egeninteressene til de aktive. Initiativtakerne hadde også det en av dem kalte for organisasjonsangst: De ville holde initiativet uformelt så lenge som mulig, uten formelle og tradisjonelle organisasjonsstrukturer. De gav derfor tidlig slipp på kontrollen med det konkrete som skjedde i aktivitetsgruppene. Initiativet utviklet på denne måten en desentralisert nettverksform med selvgående grupper knyttet sammen i et nettverk av gruppeansvarlige. På denne måten ble det etter hvert veldig mange som «eide» Bærekraftige liv på Landås, og som holdt det gående uavhengig av noen få enkeltpersoner og ildsjeler. Aktivitetsgruppestrukturen ble også lagt opp til å være fleksibel, der nye grupper kom til hvis det var interesse for det, og andre grupper gikk ut hvis det var lite aktivitet eller temaet ble mindre aktuelt. Initiativtakerne hadde det hele tiden klart for seg at de ville legge opp til et fleksibelt frivillig engasjement:

Det er en flat struktur, og vi har ventet, vi har hele veien tenkt at det som dreper ethvert gøy initiativ er at det blir dritkjedelig å ha den rollen som administrator, den som er nødt til å kalle inn til de styremøtene og så er det nesten ingen som kommer. Altså, folk syns aktiviteten er gøy, men det er utrolig kjedelig å være en sånn tradisjonell organisasjon. Så vi har bare ikke forholdt oss til et sånt organisasjonskart i det hele tatt. Vi har bare sagt at hvis du har lyst å lage et juleverksted, vær så god. Du får ingen andre oppgaver, du får ingen andre verv, ingen andre forpliktelser, bare lag juleverkstedet og hvis du har lyst å lage noe, hvis du er interessert i og engasjert i bolig og energi, ja supert, bli med i bolig og energi gruppen, det er bare det du gjør. Gjør det du syns er gøy. Og så til sammen så popper det jo opp utrolig mye. [...] Jeg tror det i hvert fall er viktig, hvis jeg kjenner på mine egne, alle snakker om tidsklemme og hvor lite tid de har og hvor mye aktiviteter og hvor fullt alt er, og det som jeg er helt hellig overbevist om er at vi får jo ingen til å gidde å gå inn i enda et verv som føles litt kjipt. Det er jo litt «takk skal du ha liksom». Men hvis jeg får lov å gjøre noe der jeg henter energi tilbake, noe jeg syns er gøy, så selvfølgelig, det er jo derfor du får jo bare pluss tilbake, pluss at du blir invitert på gøye fester med naboene, det er jo supert det. (Initiativtaker 1, BL Landås, 2012)

På tross av «organisasjonsangst» og at de ville holde tilbake formaliseringen av organisasjonen så tilknytningen mellom BL Landås og de aktive 
fortsatt skulle være uformell, førte veksten i nettverket og i aktivitetene til at en viss formalisering og institusjonalisering måtte settes i verk. I 2013 startet planleggingen av en omorganisering av Landåsinitiativet for å i større grad kunne stå på egne ben økonomisk med mer stabile inntekter, og for å skille mellom de elementene som innebar en viss økonomi, og de aktivitetene som dreide seg om frivillig engasjement og arbeid lokalt på Landås:

Organiseringsform har vi diskutert lenge, enten en lokal forening eller et samvirkeforetak, det er det vi snakker om nå. Det kommer litt an på hvordan vi sorterer de forskjellige greiene. Målet må jo være at alle initiativene skal klare seg selv økonomisk, ikke nødvendigvis være avhengig av masse offentlig støtte hele tiden, og da må vi jo først få til det på Landås for å vise at det funker. Og da må vi ha en type foretaksmodell, som kan ha inntekter inn i, medlemskap av noe slag. (Initiativtaker 2, BL Landås, 2012)

En utfordring for en mangefasettert organisasjon som Bærekraftige liv er å finne riktig organisasjonsform, noe som igjen påvirker hvilket juridisk rammeverk man må forholde seg til, hvilke rammevilkår man har, og hvilke muligheter man har for økonomisk støtte og for type styringsstruktur. Med kombinasjonen av lokalt foreningsliv, økonomisk virksomhet, samfunnsopplysning, flere enheter og grupper, ulike organisasjonsnivå og ulik grad av formalisering utviklet det seg et behov for å klargjøre hvilke organisasjonsform(er) som ville være riktig. Samtidig gjorde veksten i aktiviteter og i nettverket nasjonalt at det ble behov for et mer overordnet nasjonalt organisasjonsnivå.

Fra å ha hatt prosjektstillinger og all økonomi i BL Landås håndtert av arbeidsgiveren ${ }^{3}$ til to av initiativtakerne, så de etter hvert behov for å flytte det derifra med bakgrunn i veksten i nettverket. I 2014, seks år etter oppstarten, ble også BL Landås formelt registrert som en frivillig organisasjon med et eget styre på fire medlemmer og en styreleder, samt at den økonomiske driften knyttet til Matkollektivet ble skilt ut fra den frivillige delen ved å etablere et eget samvirkelag. De opprettet også et formelt medlemskap og støttemedlemskap i BL Landås, men dette var 
frivillig og absolutt ikke et krav for å kunne delta i aktivitetene. Samtidig startet de å arrangere årsmøter, der betalende medlemmer kunne komme med innspill til saker som kunne bli tatt opp og stemt over:

[...] nå har vi jo laget foreningen, men det er jo mange strukturer vi må rydde opp i her nå, vi har jo ikke vært opptatt av det her i det hele tatt, så nå vi har hele tiden tunga rett i munnen når vi snakker om Landås eller om Norge. Så det vi ser for oss er at den foreningen vi har starta, den blir antagelig Landås foreningen, så må vi lage noe som er hakket over som blir liksom sånn Bærekraftige liv Norge, kraftsenteret på en måte. Men det vi nå har tatt første steget på er ha laget Samvirket fordi vi ser at Matkollektivet kommer opp som en rakett, og der ble det moms og hele sulamitten ikke sant, så der måtte vi gjøre noe raskt, så da tenkte vi at ok, vi oppretter samvirket, og innen samvirket kan det være mange ting, så alle kanskje de tinga som kommer som handler om penger da, kanskje de kan settes inn der. Og vi har jo fått forespørsel om vi vil drive med el-sykler og det er flere ting som kommer opp ikke sant, så det blir litt sånn småprosjekter som handler om penger kan vi da putte inn der. Men når det gjelder hvordan få Bærekraftige liv Norge inn i det, det har vi ikke helt landa helt på, om det skal være inne i den samvirke biten eller om det blir en annen greie, men det vi ser er at vi må, vi trenger nå et overstrukturelt nivå, et nivå over Landås som er med og er en hub for alle sammen, og det er det vi ser for oss skal være på Lystgården. Og der kan jo ... (initiativtaker 1) ... tenke seg å jobbe, og det er det også vi har spurt klima- og miljøministeren om, når hun var på besøk. Vi spurte om midler til en slik pilotfase der vi prøver ut det, pluss å være en grønn frivillighetssentral, for å teste. Så det skal vi følge opp. Men vi tenker at det er, det nasjonale nivå der må staten komme inn og være med å gi penger, og der ser vi faktisk for oss at der kan vi være tre stillinger og full pakke med å gjøre ting. (Initiativtaker 3, BL Landås, 2014)

\section{Lokalt og fleksibelt}

Under oppstarten ble det geografiske området for initiativet definert til å være den lokale skolekretsen. Tanken var at for å skape engasjement og lyst til å være med og å bidra i Norge i dag, er det viktig å starte lokalt. De så den geografiske avgrensingen rundt skolekrets og lokalmiljø som 
sentral fordi dette er en naturlig grense med tanke på felles møtesteder og evne til å mobilisere engasjement i Norge.

Det som er spesielt for oss er at vi holder det så veldig ned på sånn skolekretsnivå, at vi ikke lager Bærekraftige liv Bergen. Vi har en klar idé om at i Norge forholder vi oss til skolekretsen som vårt lokalmiljø. Det er der vi har loppemarked og dugnad og går på 17. mai. Veldig mange spiller fotball og i korps og det er utrolig mye som er organisert rundt skolekretser. Og da har vi vel tenkt at en bi-effekt, en sosial «boost», som du får i nettverket, at folk sakte, men sikkert føler at dette er en invitasjon som gjelder meg - at den effekten oppnår du fortere når det er i ditt område. Og siden vår målgruppe er alle, og ikke de som allerede er interessert, så er det veldig viktig, vi har så mange ting vi må utfordre i kampen for et mer bærekraftig samfunn at vi kan ikke gidde å ta kampen om hvor vi føler oss trygge og hører hjemme. Da får vi bare spille på lag med det. Så da er vi der vi er. (Initiativtaker 1, BL Landås, 2012)

Initiativet på Landås fungerte mye som en modell for hvordan nye BLinitiativ kunne se ut, og initiativtakerne fra Landås reiste gjerne rundt til slike nystartede initiativ for å holde inspirasjonsforedrag på oppstartsmøter. De nye gruppene startet på denne måten ikke på bar bakke. Men samtidig som BL Landås var en sentral inspirasjonsmodell, ble det lagt vekt på at nye initiativ ikke på noen måte skulle være underlagt en Bærekraftige liv-organisasjon eller et sett med regler. Med unntak av invitasjon til noen felles møter i året blant alle kjernegruppene i de ulike nabolagene i Bergen, la BL Landås seg mindre opp i den videre utviklingen av nye initiativ. Så lenge initiativene forstod de to grunnpilarene 1) å øke livskvaliteten og 2) minske det økologiske fotavtrykket, så ville de kunne høre inn under Bærekraftige liv. Det skulle nemlig være opp til de nye nabolagene å selv utforme initiativene slik at de ble tilpasset det lokale området og de ønskene og behovene som lå der.

Ulike nabolag varierer for eksempel etter befolkningssammensetning basert på etnisitet og sosioøkonomisk status. Brobygging mellom ulike typer mennesker og motivasjon for engasjement vil derfor kunne ha ulike forutsetninger i ulike bydeler, og potensialene for å nå målene i Bærekraftige liv vil derfor også være ulik fra bydel til bydel og sted til sted. Organiseringsform og aktivitetstyper skulle dermed tilpasses det lokale 
nabolaget med de interessene, motivasjonen, infrastrukturen og engasjementet som lå der. For eksempel hadde BL Løvstakken et annet utgangspunkt enn flere av de andre bydelsinitiativene i Bergen, med en mye mer sammensatt befolkningsgruppe både når det gjelder økonomi og etnisitet og en lav skåre på de fleste levekårsindikatorer (Bergen kommune, 2011). Dette ble likevel sett på som positivt og et godt utgangspunkt for å få til spennende ting, der BL-konseptet med en bærekraftig livsstil ble sett på som å passe godt sammen med svakere personlig økonomi. Som initiativtaker i Bærekraftig Liv Løvstakken forklarer:

Vi har en del ting vi ønsker å ta tak i her. Det er veldig sånn sammensatt befolkningsgruppe her oppe, og det ser jo jeg som veldig positivt, det er et spennende utgangspunkt fordi det kan komme så mye forskjellig ut av det, så vi håper jo å nå mye bredere ut enn vi gjør nå. [...] Jeg syns befolkningsmessig så er det veldig spennende her. Det er ganske mange her som lever med litt stram økonomi, så det tenker jeg egentlig kan være en fordel for å få opp engasjement, på grunn av at du kan faktisk spare ganske mye på å leve mer i takt med miljøet. Hvis du begynner og bare oppdager den muligheten til å faktisk dyrke litte grann selv og la ting få et lengre liv, at ikke alt nødvendigvis må kjøpes nytt og du kan bytte på ting. Hvis vi får opp de strukturene der, at vi får opp et byttemarked som blir gående, hvis vi får en kultur på å dele, at sykler og ski blir fordelt videre til andre i nabolaget, så er det ganske mange som kan spare penger på det å være involvert. Så jeg tenker jo der at, det er spennende ting. (Initiativtaker, BL Løvstakken, 2014)

BL Løvstakken ble også raskere formalisert enn BL Landås, gjennom etablering som formell frivillig organisasjon og et styre, nedskrevne vedtekter, årsmøte, regnskap og møtebøker. Denne formaliseringen ble gjort for å gjøre det lettere å søke om offentlig økonomisk støtte. Likevel var også ønsket her at organisasjonen skulle være flatest mulig, og at ting ikke nødvendigvis skulle måtte gå igjennom styret. Noe annet som skilte BL Løvstakken fra BL Landås, var etableringen av et fysisk møtelokale midt i kjerneområdet til initiativet. Møtelokalet «Lokalt» ble et møtepunkt for BL Løvstakken, men også brukt til møter for kjernegruppene i hele Bærekraftige liv i Bergen. Finansieringen av leien av lokalet var i starten en felles kronerulling blant de aktive, samt noen inntekter fra utleie av lokalet 
og et lite bidrag fra kommunen, men målet var å få til en mer selvgående driftsmodell basert på aktiviteter.

Et tredje initiativ, BL Hellemyren, ble startet i mai 2014, i en bydel med bedre økonomiske kår og mer homogen befolkning enn i Løvstakken. Dette gav grunnlag for litt andre motivasjoner og forutsetninger for aktiviteter, for eksempel med tanke på å arrangere en byttedag:

[...] i ytre Sandviken der har vi litt mer, hva skal jeg si, vi har jo blokker, vi har forskjellige mennesker der også, men det er nok helt klart mye mindre mangfoldig sånn sett. Litt mer velstand. Jeg opplever ikke det når jeg bor der selv, men jeg tror det påvirker litt hva slags aktiviteter man får til, hva det er folk er interessert i. Det er jo så høy materiell velstand, så byttegruppe kom opp ganske raskt ikke sant. For folk har så mye ting de vil kvitte seg med uten å kaste det, kvitte seg med ting på en måte så de ikke får dårlig samvittighet. (Initiativtaker, BL Hellemyren, 2015)

Når det gjelder formaliseringen av BL Hellemyren, så hadde initiativtakeren en klar oppfatning om at folk generelt er litt redde for formalisering og administrasjon, og at man heller vil ha ting enkelt. BL Hellemyren ville heller satse på å få aktiviteter opp å gå, og så eventuelt formalisere og registrere seg som frivillig organisasjon om det ble nødvendig, for eksempel for å kunne søke om penger. Ifølge initiativtakeren var potensialet likevel stort for å få til et aktivt BL-initiativ i dette nabolaget på grunn av en ressurssterk befolkning, utdanningsmessig, økonomisk og sosialt, og der mange var svært aktive i for eksempel FAU, i skolekorpset og i idrettslaget.

For eksempel FAU på Hellen skole er jo helt sånn der, det er jo foreldre som har slike superkrefter, som har fem barn og som er engasjert i korpset, FAU, alt som går an å engasjere seg i, går fremst i 17. maitoget, buekorpset, alt, skjønner du. Det er en sånn type superforeldre. [...] Det har jeg tenkt hele tiden, at vi har så ressurssterke foreldre som kan bidra og få ting til. (Initiativtaker, BL Hellemyren, 2015)

Samtidig måtte man også her passe på å ikke lage for mye organisering og administrasjon, siden mange av de som ville delta, allerede var engasjerte i flere andre frivillige organisasjoner og ville ha begrenset med tid. En 
annen utfordring med å skape engasjement i denne lokalbefolkningen var å treffe de med rett budskap og en tankegang rundt BL-prosjektet som de kunne identifisere seg med, der man ikke hadde for mye fokus på dette med miljøaktivisme, noe som også var et tema på Landås, der man måtte tone ned «tofu-faktoren».

Det er litt om å gjøre å treffe de på en måte som gjør at de føler de kan identifisere seg, og da er vi litt tilbake igjen til at vi må være litt forsiktige med dette med miljøaktivistbevegelsen, nettopp på grunn av det. Det er ikke til å komme ifra at det er en del godt holdne mennesker som bor der ute. (Initiativtaker, BL Hellemyren, 2015)

\section{Refleksiv institusjonalisering}

Gjennom studien av Bærekraftige liv i Bergen har jeg fått innblikk i perspektiver og måter å organisere og forvalte frivillig engasjement på i dag. Erfaringene fra denne studien kan knyttes til observerte endringer i holdninger, motivasjoner og forventninger fra frivillige i Norge, samt de etablerte måtene å organisere kollektiv handling på. Jeg mener med dette at studien illustrerer generelle endringstrekk i nordmenns frivillige engasjement og hvordan institusjonaliserte rammer for organisering av frivillig engasjement er med på å strukturere fremveksten og organiseringen av nytt frivillig engasjement i Norge. Samtidig vil det også, som vist i studien, være et visst rom for aktørers utprøving og kreativitet - en fortolkningsfleksibilitet i hvordan man mobiliserer og organiserer for lokal frivillig aktivitet.

Studien har først vist at det er flere trekk ved Bærekraftige liv som støtter opp om teorien om refleksiv frivillighet (Hustinx \& Lammertyn, 2003), og som illustrerer de mer generelle utviklingstrekk i norsk frivillighet (Eimhjellen et al., 2018). Dette er særlig knyttet til utviklingen av mer selv-orienterte frivillige, som fordrer en mer uformell og desentralisert form for organisering. Som studien min har vist, vil én strategi i møte med mer refleksive frivillige være å ta utgangspunkt i og fokusere på nettopp interessene og ressursene hos de aktive selv i avgrensede nabolag. Det kan legges til rette for at aktive kan bidra med og delta med det 
de ønsker, når de ønsker det, og hvordan de ønsker det, uten å stille for mange krav til møtevirksomhet og administrative oppgaver. Rammene for hva som passer inn av aktiviteter, må her være relativt vidt definert, og det må være frie tøyler for de aktive til å skape nye aktiviteter. Aktivitetene kan foregå i relativt selvstyrte grupper som er koblet sammen i nettverk. Samtidig kan det være fleksibelt med hensyn til å åpne for administrativt engasjement på «høyere» organisasjonsnivå for de som skulle ønske det. En slik (nettverks-)organisering fordrer likevel at det eksisterer en egen organisasjonsposisjon, for eksempel en lønnet ansatt, for å gjøre administrasjons- og koordineringsarbeid (Jf. Arnesen et al., 2016). Å ha ansatte i organisasjoner som arbeider med mobilisering og koordinering av frivillig innsats, kan være en god strategi for å forvalte dagens frivillige på en bærekraftig måte.

Fra teorien om refleksiv frivillighet er det også innebygd en forventning om at frivillige organisasjoner har fått svekkede roller som arenaer for identitetsutvikling og sosialisering. Studien av Bærekraftige liv bryter med slike forventninger, siden dette initiativet er spesifikt opptatt av nettopp å skape stedbunden identitet og samhold i fysiske nabolag. Dette er også en trend vi ser mer generelt i Norge, der frivillig organisering knyttet lokalsamfunn og nabolag er i vekst (Christensen, Strømsnes \& Wollebæk, 2011; Arnesen et al., 2016). Basert nettopp på det stedbundne ved Bærekraftige liv hadde også digital kommunikasjon en mer marginal rolle enn vi kanskje skulle forvente av nyere grasrotinitiativ, og sammenlignet med for eksempel Refugees Welcome to Norway fra forrige kapittel (se også Sætrangs kapittel 6 i denne boken). I Bærekraftige liv var ansikt til ansikt-møter ved fotballbanen, informasjonslapper på lokalbutikken og på lyktestolper samt medieoppmerksomhet utenfra viktigere enn digitale kanaler for å mobilisere aktivitet i oppstarten. Skolekretser og nabolag ble vurdert som de beste områdene for at potensielle engasjerte skulle kunne identifisere seg med initiativene og oppleve at engasjementet gjaldt dem selv. Store nok til å samle en kritisk masse, men små nok til at mennesker kjente tilhørighet. Som en effekt av veksten i initiativene i nabolagene har internett og sosiale medier etter hvert fått en viktig rolle i informasjonsdistribusjon og administrering av frivillig aktivitet, men dette har skjedd mest som en effekt av aktivitetsvekst og ikke omvendt. 
Selv om Bærekraftige liv har vært opptatt av at handlinger og aktiviteter i initiativet skal være lokale, har globaliseringsprosesser og globalt klimaengasjement vært en sentral motivasjon for initieringen av Bærekraftige liv. Dette kan knyttes til begrepet om glokalisering (Robertson, 1995), som henviser til at globalisering av kultur, ideer og levesett også fører til økt fokus på lokal identitet og særpreg. Det globale kan bli uttrykt i det lokale samtidig som det lokale blir en partikularisering av det globale. Den internasjonale Transition-towns-bevegelsen, som Bærekraftige liv på Landås er blitt en del av, har nettopp dette glokale som et kjerneelement i seg. Globale tema får på denne måten direkte innvirkning på lokalt grasrotengasjement også i Norge, der lokal orientering og mer refleksive former for frivillig innsats er del av en større global vending.

Som følge av det økte volumet av og mangfoldet i aktiviteter, aktive og nye initiativ i Bærekraftige liv-nettverket har vi også sett at behov for mer formell administrativ og sentralisert organisering har presset seg frem. For å kunne utvikle initiativet og etablere en bærekraftig økonomi måtte det etter hvert tilpasses eksisterende normer og juridiske rammeverk for organisering av kollektiv handling og økonomihåndtering. En viss institusjonalisering og formalisering ser ut til å være nødvendig for å kunne bevare, utvikle og forvalte frivillig engasjement. Samtidig varierte implikasjonene av slike kontekstuelle krav med de forutsetninger og behov som eksisterte i de enkelte nabolagsinitiativene. Vi så for eksempel stor forskjell mellom BL Landås og BL Løvstakken i bakgrunn for og tidspunkt for formalisering av organisasjonene. Som organisasjon har hele Bærekraftige liv vært nødt til å balansere hensynet til motivasjon hos de aktive og frivillige og de juridiske og økonomiske rammeverkene som regulerer organisasjonsetablering og inntekts- og støttemuligheter. Nettverksutvidelse førte her med seg behov for sentralisering og formalisering. På samme vis som tidligere grasrotbevegelser med antiorganiseringsholdninger eller «organisasjonsangst» har også Bærekraftige liv blitt formalisert og institusjonalisert ved å måtte forholde seg til etablerte strukturer, tradisjoner og praksiser for organisasjonsdannelse og drift.

Samtidig vil det også i hvert konkrete tilfelle av grasrotmobilisering være rom for fortolking, fleksibilitet og kreativitet $i$ hvordan mobiliseringen og organiseringen gjøres. Dette har vi også sett som bevisst strategi 
i Bærekraftige liv, der ulike nabolagsinitiativ skal ta utgangspunkt i de sosiale og fysiske forutsetningene og ressursene som ligger i hvert nabolag. Det finnes handlings- og fortolkningsrom som etter hvert også kan være med på å endre de etablerte rutinene, praksisene og normene for hvordan man organiserer og forvalter frivillig engasjement i Norge, men slikt tar tid. Jeg mener med dette at sosial og institusjonell endring og stabilitet er sammenvevd, der impulser fra større samfunnsprosesser som globalisering, individualisering og digitalisering, og ikke minst fra institusjonaliseringsprosesser, kan fortolkes ulikt og ha ulike konsekvenser i handlinger og praksiser i ulike sosiale kontekster og for ulike konkrete initiativ og organisasjoner. Organisatoriske reaksjoner på frivillighetstrender knyttet til mer refleksivitet vil måtte balanseres mot de kontemporære behovene for og normer og krav til organisering som eksisterer i et gitt samfunn.

Et forslag til begrep som kan beskrive gripe noe av denne dynamikken i organiseringen av nytt frivillig engasjement, er det jeg har kalt refleksiv institusjonalisering. Begrepsbiten refleksiv refererer til den veksten i refleksiv frivillighet som vi kan spore i Norge og internasjonalt, og hvordan organisasjoner i økende grad må forholde seg til dette. Jeg mener her at det ligger et fortolkningsrom for organisering av frivillig engasjement et sted imellom de etablerte tradisjonene og strukturene for organisering og de endringspåtrykkene som kommer fra overordnede samfunnsprosesser. Begrepsbiten institusjonalisering viser så til at en viss form for formalisering og etablering av faste strukturer i en voksende (nettverks-) organisasjon ofte er helt nødvendig for videre aktivitet, samt at det eksisterer visse tradisjoner, normer og regler som legger føringer og rammer for utviklingen og organiseringen av frivillige initiativ.

Med bakgrunn i denne studien og tidligere forskning på utviklingen i norsk frivillighet vil jeg argumentere for at man bør ha et blikk for endring, men også for kontinuitet, og for vekselvirkninger mellom ulike samfunnsnivå - mellom individnivå og institusjonelt / organisasjonsnivå, mellom globalt nivå og lokalt nivå, og mellom aktør og struktur - når man undersøker hvordan kollektiv handling går for seg i dag. Begrepet refleksiv institusjonalisering kan hjelpe oss å gripe og forstå disse prosessene og vekselvirkningene. På tross av flere endrings- og 
utviklingstendenser i norsk frivillighet er tradisjonelle formelle frivillige organisasjoner fortsatt den sentrale infrastrukturen for mobilisering og forvaltning av frivillig engasjement i Norge, selv om de frivillige er løsere koblet til organisasjoner nå enn før. For å dyrke grasrotengasjement og -aktivitet er kanskje et skille mellom grasrotaktiviteter og frivillige på en side, og administrasjons- og koordineringsansvar på den andre en forutsetning. Dette vil likevel kreve både vilje hos enkelte og insentiver og ressurser til lønnede stillinger i organisasjoner.

Nye organisasjoner vil i dag kunne bli preget av både hierarkiske og nettverksbaserte kjennetegn med kombinasjoner av desentralisering og sentralisering, fleksibilitet og struktur, hierarkisk og vertikal styring og lokale og globale nettverk. Samtidig vil de som oftest måtte gå igjennom en viss organiserings- og institusjonaliseringsprosess for å fungere etter målsettingene sine der de vil prøve å finne sin form basert på både organisasjonsinterne og organisasjonseksterne normer og krav, men der det også kan være et visst rom for kreativitet og refleksivitet - en refleksiv institusjonaliseringsprosess for nye kollektive bevegelser.

\section{Litteratur}

Arnesen, D., Sivesind, K. H., \& Gulbrandsen, T. (2016). Fra medlemsbaserte organisasjoner til koordinert frivillighet? Oslo: Senter for forskning på sivilsamfunn og frivillig sektor.

Beck, U., \& Beck-Gernsheim, E. (2002). Individualization: Institutionalized Individualism and its social and political consequences. London: Sage.

Beck, U. (1992). Risk society: Towards a new modernity. London: Sage.

Bennet, L. (1998). The uncivic culture: Communication, identity, and the rise of lifestyle politics. Political science and politics 31: 41-61.

Bennet, L. (2008). Changing citizenship in the digital age. I W. L. Bennet WL (Red.) How digital media can engage youth. Cambridge, MA: MIT Press, 1-24.

Bennet, L., \& Segerberg A. (2013). The logic of connective action. Information, Communication and Society 15: 739-768.

Bimber, B., Flanagin, A. J., \& Stohl, C. (2012). Collective action in organizations. Interaction and engagement in an era of technological change: Cambridge University Press.

Christensen, D.A., Strømsnes, K., \& Wollebæk D. (2011). Organisasjonene i Hordaland 1999-2009. Bergen: Senter for forskning på sivilsamfunn og frivillig sektor. 
Dalton, R. (1998). Citizen politics in western democracies, New Jersey: Chatham Enjolras, B., \& Strømsnes, K. (2018). Scandinavian Civil Society and Social Transformations: The Case of Norway. Springer

Eimhjellen, I., Steen-Johnsen, K., Folkestad, B., \& Ødegård, G. (2018) Changing patterns of volunteering and participation. I B. Enjolras \& K. Strømsnes (Red.) Scandinavian Civil Society and Social Transformations: The Case of Norway. Springer

Flamoe, A, Sivesind, K.H., \& Arnesen, D. (2018) Oppdaterte tall om frivillig innsats i Norge, 1998-2017. Senter for forskning på sivilsamfunn og frivillig sektor. Bergen/ Oslo.

Folkestad, B., Christensen, D. A., Strømsnes, K., \& Selle, P. (2015). Frivillig innsats i Noreg 1998-2014. Senter for forskning på sivilsamfunn og frivillig sektor. Bergen/ Oslo.

Giddens, A. (1991a). The consequences of modernity. Stanford, CA: Stanford University Press.

Giddens, A. (1991b). Modernity and Self-identity: Self and Society in the Late Modern Age, Cambridge: Polity Press

Giddens, A. (1976). New rules of sociological method, New York: Basic Books.

Giddens, A. (1979). Central problems in social theory: Action, structure and contradiction in social analysis. Berkeley, CA: University of California press.

Giddens, A. (1984). The constitution of society: Outline of the theory of structuration, Berkeley, CA: University of California press.

Hustinx, L., \& Lammertyn, F. (2003). Collective and reflective styles of volunteering: A sociological modernization perspective. Voluntas, 4.

Ingelhart, R. (1990). Culture shift in advanced industrial society, Princeton, NJ: Princeton University Press.

Ingelhart, R. (1997). Modernization and postmodernization: Cultural, economic and political change in 43 societies, Princeton, NJ: Princeton University Press.

Kontopoulos, K.M. (1993). The logics of social structure. Cambridge: Cambridge University Press.

Kvale, S., \& Brinkman, S. (2015) Det kvalitative forskningsintervju. 3utg. Oslo: Gyldendal norsk forlag.

Mahoney, J., \& Thelen, K. (Red.). (2010). Explaining institutional change. Ambiguity, agency and power. Cambridge: Cambridge University Press.

McDonald, K. (2002). From solidarity to fluidarity: Social movements beyond "collective" identity - the case of globalizations conflicts. Social movement studies 1: 109-128.

Norris, P. (1999). Critical citizens. Global support for democratic governance, Oxford: Oxford University Press.

Norris, P. (2001). Digital divide: Civic engagement, information poverty, and the Internet worldwide, New York: Cambridge University Press. 
della Porta, D. (2005). Multiple belongings, flexible identities and the construction of "another politics": between the European social forum and the local social fora. I D. Della Porta \& S. Tarrow (Red.) Transnational protest and global activism. Boulder, CO: Rowman \& Littlefield.

Powell, W. (1990). Neither Markets nor hierarchy: Network forms of organizations. I Slaw, B. (Red.) Research in organizational behavior. Vol 12. Greenwich, CT. JAI Press. Pp 295-336.

Putnam, R.D. (2000). Bowling Alone. The collapse and revival of American community, New York: Simon \& Schuster Paperbacks.

Robertson, R. (1995). Glocalization: Time-space and homogenity-heterogenity. I M. Featherstone, S. Lash \& R. Robertson (Red.), Global Modernities. Londin: Sage.

Selle, P., \& Øymyr, B. (1995). Frivillig organisering og demokrati. Det frivillige organisasjonssamfunnet 1940-1990. Oslo: Det Norske Samlaget.

Skocpol, T., \& Fiorina M.P. (1999). Civic engagement in American democracy: Brookings Institution Press.

Smith, A. (2011). The Transition Town Network: A Review of Current Evolutions and Renaissance. Social Movement Studies, 10/01, 99-105.

Van Dijk, J. (2012). The network society, London: Sage.

Wollebæk, D., Lorentzen, H., \& Selle, P. (2000). Frivillig innsats. Sosial integrasjon, demokrati og økonomi. Fagbokforlaget.

Wollebæk, D. \& Selle P. (2002). Det nye organisasjonssamfunnet. Demokrati i omforming Bergen: Fagbokforlaget.

Wollebæk, D, Fladmoe, A., \& Sætrang, S. (2015). Betingelser for frivillig innsats. Motivasjon og kontekst. Oslo: Senter for forskning på sivilsamfunn og frivillig sektor. 


\title{
Nasjonale organisasjoners bruk av sosiale medier. Muligheter og barrierer for bruk
}

\author{
Audun Beyer \\ Institutt for samfunnsforskning \\ Kari Steen-Johnsen \\ Institutt for samfunnsforskning
}

\begin{abstract}
In this chapter, we investigate the ways in which national voluntary organizations have employed new digital media. We study in particular whether digitization seems to enable new organizational forms; if it contributes to new ways in which organizations can engage members and volunteers; and how the new digital media can contribute to, for example, public debate. We ask if organizations differ in such use, and whether certain types of organizations are more likely to use new forms of communication, both to inform members and to participate in the public. For instance, do organizations that were established after the rise of social media (digital natives) use new media differently than older organizations? Secondly, we investigate what kinds of barriers that can prevent the use of social media by such organizations

Our findings initially point out that the use of internet and social media largely permeates all types of organizations in Norway, but that there are important differences between different organizations. Furthermore, we identify different dimensions in terms of the use of social media, with clear distinctions between public activities on the one hand and activity directed at members on the other. Finally, we find that a lack of resources is the main causal factor when it comes to the organizations that not use social media.
\end{abstract}

Keywords: national voluntary organizations, internet, social media

Sitering av denne artikkelen: Beyer, A., A Steen-Johnsen, K. (2018). Nasjonale organisasjoners bruk av sosiale medier. Muligheter og barrierer for bruk. I B. Enjolras \& I. Eimhjellen (Red.), Fra kollektiv til konnektiv handling? Nye former for samfunnsengasjement og kollektiv handling $i$ Norge (s. 235-270). Oslo: Cappelen Damm Akademisk. https://doi. org/10.23865/noasp.45.ch9

Lisens: CC BY-NC 4.0 


\section{Innledning}

Ny kommunikasjonsteknologi vil alltid representere endrede betingelser for kommunikasjon og nye muligheter for forbindelser mellom deltakerne i kommunikasjonsprosessen. Når et nytt medium introduseres, vil gamle kommunikasjonsformer utfordres, og vi vil kunne observere endringer både i hvordan de som sender budskap oppfører seg, og i bruk på mottakersiden. Som vi har sett i flere andre kapitler i denne boken (f.eks. kap. 3 og kap. 4), har det de siste tiårene vært viet stor oppmerksomhet til om internett og sosiale medier endrer og påvirker medborgerskap og samfunnsdeltakelse (Dahlgren, 2009; Enjolras, Karlsen, Steen-Johnsen, \& Wollebæk, 2013; Norris, 2001).

Temaet for denne boken er hvorvidt og på hvilke måter digitalisering, individualisering og globalisering endrer vilkårene for kollektive handlingsformer. I dette kapitlet studerer vi hvordan disse prosessene kommer til uttrykk når norske organisasjoner tar i bruk sosiale medier som en ny måte å organisere kollektiv handling på. Mens andre kapitler i boken fokuserer på individuell deltakelse i lys av digitalisering, inntar vi dermed her et organisasjonsperspektiv. For å forstå hvordan digitaliseringen påvirker kollektiv handling i Norge, mener vi det er viktig å inkludere begge disse perspektivene.

Frivillige organisasjoner har i over hundre år representert et sentralt bidrag til sivilt medborgerskap. I de siste tiårene har man sett klare endringer i hvordan dette landskapet har endret seg, fra en folkebevegelsesmodell, med hierarkiske strukturer, til mer desentraliserte organisasjoner med spesialiserte formål (Arnesen, Sivesind \& Gulbrandsen, 2016). Dette nye landskapet som frivillige organisasjoner må operere $i$, kan blant annet medføre økt konkurranse mellom organisasjoner, der man må bruke de ressursene man har, mer effektivt. Å ta i bruk nye måter å kommunisere med både medlemmer og offentligheten på kan derfor tenkes å representere potensielle fordeler for organisasjonene som lykkes (Eimhjellen, 2014).

Samtidig viser både norsk og internasjonal forskning at frivillige organisasjoner langt fra står lengst frem i køen når det gjelder å ta i bruk og utnytte mulighetene som ligger i sosiale medier (Eimhjellen, 2014a; Lovejoy \& Saxton, 2012). Det kan være flere grunner til dette. Selv om sosiale medier i utgangspunktet er rimelige og enkle å ta i bruk (Benkler, 2006), kan det 
likevel kreve ressurser i form av kompetanse og oppmerksomhet fra organisasjonenes side (Asencio \& Sun, 2015; Eimhjellen, 2014b). Det kan også tenkes at frivillige organisasjoner opplever at det å ta i bruk sosiale medier utfordrer deres tradisjonelle virkemåte, og at det endrer relasjonen deres til offentligheten og til medlemmer på måter som er vanskelige å forutsi. En kvalitativ studie fra 2012 pekte på at norske frivillige organisasjoner så utfordringer både knyttet til organisasjonsidentitet, medlemsdemokrati, kompetanse og ressursbruk i sin bruk av sosiale medier (Steen-Johnsen, Enjolras \& Kruse, 2012). Samtidig viste studien at ulike sider ved organisasjonen kunne ha betydning for hvorvidt organisasjoner ønsket og evnet å ta i bruk sosiale medier, blant annet organisasjonskultur, kompetanse og organisasjonens formål. De to organisasjonene med politisk siktemål, og med mål om å påvirke opinionen, så bruken av sosiale medier som viktigere enn den fritidsrettede organisasjonen som inngikk i studien. I sin studie av lokale frivillige organisasjoners bruk av web og sosiale medier fant Eimhjellen mfl. et sett faktorer som hadde betydning for bruk (Eimhjellen, Wollebæk \& Strømsnes, 2014). Bruken av digitale verktøy var mer utbredt i store og relativt nystiftede organisasjoner, i organisasjoner i byene og i organisasjoner med høyere andel yngre medlemmer. Til slutt kan ulike typer av organisasjoner ha ulike grunner og forutsetninger for å ta i bruk slike verktøy. Det er likevel ikke gitt om det er de store og ressurssterke organisasjonene med en etablert infrastruktur som er best rustet, eller om mindre, nye typer av organisasjoner har bedre forutsetninger. Mest sannsynlig vil vi kunne observere en kombinasjon; på den ene siden vil de med ressurser ha et fortrinn, men på den andre siden muliggjør også sosiale medier fremveksten av mer løsrevne organisasjonsformer som kan mobilisere bredt uten en stor organisasjon bak seg.

Status når det gjelder forskning knyttet til frivillige organisasjoners bruk av sosiale medier, er likevel at vi vet forholdsvis lite både om bruk og effekter, i Norge som internasjonalt (Guo \& Saxton, 2014; Lovejoy \& Saxton, 2012). Dette kapitlet gir et bidrag til litteraturen ved å gi det første oversiktsbildet av sosial mediebruk blant norske nasjonale frivillige organisasjoner. Ved hjelp av en representativ spørreundersøkelse av om lag 1000 norske frivillige organisasjoner svarer vi på hvorvidt det eksisterer skiller mellom ulike typer av organisasjoner når det gjelder å ta i bruk, 
aktivt bruke og forholde seg til mulighetene som ligger i bruk av nye kommunikasjonsformer. Vi undersøker også hva de ulike organisasjonene bruker internettbaserte og sosiale medier til, om det først og fremst er for å oppdatere medlemmer, eller om det er en mer utadrettet virksomhet, der slike kommunikasjonsformer brukes aktivt til å skape debatt $\mathrm{i}$ offentligheten eller påvirke beslutningstakere. Til slutt presenterer vi også analyser av hvilke fordeler og ulemper organisasjonene mener at internett og sosiale medier representerer, og hvorfor enkelte organisasjoner ikke har valgt å ta i bruk sosiale medier ennå.

I kapitlet har vi en spesiell interesse for det vi har valgt å kalle digitalt innfødte organisasjoner, det vil si organisasjoner som har blitt etablert etter, eller samtidig som, fremveksten av sosiale medier. En antagelse kan være at disse i større grad enn andre organisasjoner makter å ta i bruk slike verktøy, blant annet fordi de kan integreres i måten organisasjonen drives på helt fra starten av. Vi gjør en analyse av de digitalt innfødte organisasjonene i siste del av kapitlet. Dataene som kapitlet bygger på, er i denne sammenheng ganske unike, og vi kjenner ikke til tilsvarende undersøkelser i Norge eller internasjonalt. Samtidig er dataene samlet inn så tidlig som i 2013, noe som legger noen klare begrensninger for fortolkningen av resultatene. Analysene må derfor betraktes som det de er, analyser av de første 6-8 årene da sosiale medier kan ha spilt en rolle for norske organisasjoner. Dette gjenspeiles i vårt fokus på det vi kaller digitalt innfødte organisasjoner. Det er åpenbart at den teknologiske utviklingen har kommet langt etter disse første årene, samtidig som både folks og organisasjoners medievaner og mediekompetanse har endret seg. Dette kan ikke vår undersøkelse si noe om. Vi håper imidlertid at studien kan være et solid grunnlag for oppfølgingsstudier, som dermed kan peke på endringer som har skjedd siden innføringen av sosiale medier, og i den tiden da disse kommunikasjonsformene har blitt allemannseie.

\section{Teoretiske perspektiver og forskningsspørsmål}

Forskningslitteraturen knyttet til frivillige organisasjoner har pekt på at både det norske og det internasjonale organisasjonslandskapet er i endring de siste tiårene (Arnesen et al., 2016; Eimhjellen, 2014). På den ene 
siden handler det om en overgang fra sentraliserte, hierarkiske organisasjoner med et ideologisk fundament til mer løsrevne, desentraliserte organisasjoner uten et så klart ideologisk grunnlag, og et sterkere fokus på spesifikke enkeltsaker (Arnesen et al., 2016). På den andre siden handler det om at ny teknologi utfordrer tradisjonelle organisasjoner, og muliggjør nye organisasjonsformer, delvis tilsvarende motsetningen mellom sentraliserte og desentraliserte organisasjoner, som beskrevet over. Begge disse tendensene er viktige for problemstillingene i dette kapitlet.

\section{Teknologi og organisasjoner i endring}

I litteraturen finner vi flere eksempler på ulike forventninger til hva implementering av ny teknologi kan ha for frivillige organisasjoner. Her er det først og fremst snakk om potensialer ved å ta i bruk nye kommunikasjonsteknologier, og ikke nødvendigvis at organisasjonene faktisk alltid utnytter disse potensialene. Som Eimhjellen (2014) peker på, er det fortsatt slik at reell interaktivitet, som ligger som en strukturell mulighet ved mange internett-baserte medier, ikke utnyttes særlig godt av frivillige organisasjoner. Internasjonal forskning tyder på det samme (Bortree \& Seltzer, 2009; Greenberg \& Macaulay, 2009). Lignende funn finner vi også i for eksempel myndigheters bruk av slike teknologier, som på tross av en stor grad av optimisme på teknologiens vegne (se Bryer \& Zavattaro, 2011) i stor grad er dominert av enveis kommunikasjon (Zavattaro \& Sementelli, 2014). Også studier av politikeres bruk av sosiale medier dokumenterer en stor grad av mangel på interaktivitet (Larsson \& Kalsnes, 2014; Larsson, Kalsnes \& Christensen, 2017).

Når det gjelder hva frivillige organisasjoner - eller det bredere feltet av non profit-organisasjoner (NPO-er), som ofte er fokus i den internasjonale litteraturen - faktisk bruker sosiale medier til, er det en antagelse at det finnes stor variasjon, og at dette antagelig må studeres felt for felt, avhengig av hva organisasjonene har som hovedformål (Acensio $\&$ Sun, 2014). I en mye sitert artikkel har Lovejoy og Saxton (2012) identifisert tre hovedfunksjoner sosiale medier kan fylle, basert på en studie av Twitter-bruk i 100 store veldedighetsorganisasjoner. De tre funksjonene er henholdsvis information, community og action. «Informasjon» 
handler om å spre informasjon om organisasjonens formål og aktiviteter, «community» handler om å skape bånd til interessenter og relevante samarbeidspartnere, ofte ved å takke og anerkjenne disse, mens «action» innebærer at man oppfordrer til handling, enten ved å donere penger, yte en innsats eller lignende (2012, s. 343). En studie av sosial mediebruk $i$ et stort antall amerikanske «advocacy»-organisasjoner, altså organisasjoner som arbeider med å fremme bestemte politiske saker og interesser, understreker at sosiale medier kan fylle ulike funksjoner for ulike typer organisasjoner (Guo \& Saxton, 2014). Her identifiserer forfatterne tre suksessive faser i bruk som knyttes til mobiliseringen rundt politiske saker: «nå ut til folk», «holde liv i flammen» og «motivere til handling» (2014, s. 53).

Mens hovedtyngden av studier av sosial mediebruk blant NPO-er fokuserer på sosiale medier som verktøy for utadrettet virksomhet, finnes det studier i norsk kontekst som peker på sosiale medier som verktøy for intern kommunikasjon. I en studie av fire frivillige organisasjoner peker Tranvik og Selle (2008) på at disse organisasjonene hadde visjoner om å bruke digitale medier til å bedre intern kommunikasjon horisontalt og vertikalt, men at disse ambisjonene ikke ble innfridd. Den kvalitative studien fra 2012 (Steen-Johnsen mfl.) viste også ambisjoner om å kommunisere og mobilisere medlemmer på nye måter, å styrke interndemokratiet og å skape en annen flyt mellom fag og kommunikasjon sentralt i organisasjonen. Disse studiene understreker at bruk av sosiale medier ikke bare angår frivillige organisasjoners forhold til omverden, men også kan gripe inn i interne organisatoriske forhold.

\section{Betydningen av organisasjoners struktur og funksjon}

Selv om eksisterende forskning om frivillige organisasjoners bruk av sosiale medier, internt og eksternt, er begrenset og fragmentert, antyder den likevel betydningen av å se bruken i sammenheng med en organisasjons struktur, formål og hovedoppgaver. Det norske landskapet av nasjonale, frivillige organisasjoner, som vi her studerer, er svært sammensatt, og dessuten i endring. Vår tilnærming til å belyse variasjonene i dette, 
er å undersøke forskjeller mellom noen grunntyper av organisasjoner: nasjonalledd med lokale lag, enkeltstående organisasjoner og paraplyorganisasjoner. Nasjonalledd med lokale lag er en organisasjonsform som tradisjonelt har kjennetegnet den nordiske sivilsamfunnsmodellen (Arnesen, Sivesind \& Gulbrandsen, 2016; Selle, 1993; Wollebæk \& Selle, 2008). Disse organisasjonene er gjerne kjennetegnet ved vel utbygde nasjonalledd (selv om størrelsen på administrasjonen kan variere sterkt) og av veletablerte vertikale kommunikasjonslinjer gjennom regionale og lokale ledd. De har også gjerne tydelige demokratiske prosedyrer og prosesser som sikrer kommunikasjon nedenfra og opp. Disse organisasjonene er oftest medlemsbaserte, med sterke koblinger mellom medlem og organisasjon. Enkeltstående organisasjoner har ikke underliggende lokale strukturer, men er avhengig av direkte medlemskommunikasjon i den grad de har medlemmer. Denne organisasjonstypen har vært i vekst i Norge de siste ti årene (Arnesen et al., 2016), og en hypotese har vært at nettopp sosiale medier og internett har muliggjort veksten i slike organisasjoner, fordi de kan kommunisere både til medlemmer og til offentligheten uten det settet av interne kommunikasjonsstrukturer som nasjonalleddene besitter (Arnesen et al., 2016, 90). Paraplyorganisasjoner er sammenslutninger av selvstendige frivillige organisasjoner, med formål om samarbeid, ressursutnyttelse og politisk påvirkning. Noen paraplyorganisasjoner har lange tradisjoner, slik som Norges idrettsforbund (Goksøyr, 1993), mens andre, slik som Frivillighet Norge, er av nyere dato. Paraplyorganisasjoner kan gjerne ha kommunikasjon av medlemsorganisasjonenes interesser i offentligheten som en viktig del av sitt virke.

Et interessant perspektiv på hvilke forutsetninger ulike organisasjonsformer legger, er Bennett og Segerbergs (2014) påpekning av at organisasjoner kan forstås som strukturer for å samle, organisere og binde ressurser, og som strukturer for kommunikasjon. Når veletablerte systemer for kommunikasjon skal ta i bruk nye kommunikasjonsmidler, oppstår det gjerne brytninger mellom etablerte og nye strukturer, noe som kan forklare både begrenset og konservativ bruk, samt at organisasjonen opplever barrierer. I vår analyse er det derfor viktig å ha forutsetningene som ligger i disse organisasjonstypene, i mente. I tillegg antyder dette perspektivet også noe om hvorfor vi kanskje kan forvente at digitalt 
innfødte organisasjoner med større letthet utnytter potensialene i sosiale medier. Dette kan handle om at digitale verktøy blir en integrert del av organisasjonsstrukturen fra begynnelsen av.

Endelig vil også målene og aktivitetene i organisasjonene legge viktige forutsetninger for deres bruk av sosiale medier og deres muligheter. Det er for eksempel stor forskjell på organisasjonene innenfor kultur- og idrettsfeltet, som har sin hovedvirksomhet i organiseringen av lokale aktiviteter, og samfunnsrettede organisasjoner, som har som formål å påvirke politiske saker gjennom offentlig debatt.

\section{Forskningsspørsmål}

I kapitlet stiller vi fire forskningsspørsmål, som alle er rettet inn mot å gi et beskrivende bilde av bruken av sosiale medier blant nasjonale frivillige organisasjoner i Norge:

Hva kjennetegner omfanget av bruk av internett og sosiale medier i norske, frivillige organisasjoner?

Hva bruker frivillige organisasjoner sosiale medier til?

Hvordan oppfatter organisasjonene utfordringer og nytteaspekter knyttet til internett og sosiale medier?

Hvordan skiller digitalt innfødteorganisasjoner segfra andre organisasjoner?

Først undersøker vi omfanget av bruken av internett og sosiale medier i norske frivillige organisasjoner, og hvilke forskjeller det er mellom ulike typer av organisasjoner. Vi vet at tilgangen til internett er spesielt høy i Norge sammenlignet med de fleste andre land (SSB, 2016), og det er grunn til å tro at dette gjelder for organisasjoner også. Det er likevel viktig å fastslå hvor omfattende bruken av internettbaserte medier er, og om det er forskjeller mellom organisasjoner.

For det andre undersøker vi hva de forskjellige organisasjonene oppgir å bruke sosiale medier til. Gitt at en organisasjon har profiler på sosiale medier, er det likevel et åpent spørsmål hva de faktisk bruker disse verktøyene til. I vår undersøkelse har vi stilt en rekke spørsmål som bidrar til å nyansere mer kvalitative forskjeller i bruken av spesielt sosiale medier. Vi kan for eksempel trekke et skille mellom å bruke sosiale medier opp 
mot medlemmer og/eller å kommunisere mot en bredere offentlighet, og bruk som er mer knyttet opp mot driften av organisasjonene. Også her vil det være naturlig å se på disse ulike aktivitetene opp mot ulike typer av organisasjoner.

For det tredje vil vi undersøke hvilke utfordringer og nytteaspekter organisasjonene oppgir som viktige knyttet til internett og sosiale medier. Vi forventer en klar sammenheng mellom hva de oppgir som nytte, og hva de faktisk bruker internett og sosiale medier til (undersøkt i forrige spørsmål), men vi stiller også en rekke spørsmål som er mer spesifikt knyttet til sosiale medier, og særlige egenskaper ved disse. Vi stiller blant annet spørsmål om sosiale medier tar for mye ressurser, og styrer aktiviteten i organisasjonene bort fra kjernevirksomheten. Andre relevante spørsmål knytter seg til om sosiale medier på noen måter utfordrer medlemsdemokratiet, for eksempel ved at personer utenfor organisasjonen oppfattes å få for mye innflytelse over virksomheten.

Til slutt vil vi undersøke bruk av sosiale medier i digitalt innfødte organisasjoner. Her velger vi å studere organisasjoner stiftet etter 2006, og spørre om disse skiller seg fra andre organisasjoner på noen måte. Årstallet er valgt fordi 2006 var året da Facebook åpnet opp for alle brukere. Twitter startet også sin åpne virksomhet dette året. Et sentralt spørsmål er altså om organisasjoner som startet sin virksomhet samtidig som eller etter at sosiale medier ble tilgjengelig, har en mer omfattende og integrert bruk av sosiale medier for sine formål enn andre organisasjoner.

\section{Data og metode}

Analysene i dette kapitlet bygger på data fra en web-undersøkelse blant nasjonale frivillige organisasjoner, gjennomført av Respons Analyse i perioden mai-oktober 2013. Oppdragsgiver for datainnsamlingen var Senter for forskning på sivilsamfunn og frivillig sektor. Gruppen av organisasjoner som skulle motta undersøkelsen, ble etablert ved at Brønnøysundregistrene samlet inn informasjon om alle relevante organisasjoner fra Enhetsregisteret og Frivillighetsregisteret. Det ble deretter gjort en sortering, slik at lokallagene til sentralledd, organisasjoner som var ikke-nasjonal avdeling $i$ en annen organisasjon, organisasjoner 
som var kvalifisert til å motta grasrotandel, samt ideelle velferdsprodusenter ble tatt ut av populasjonen. I underkant av 5000 organisasjoner ble identifisert som relevante deltakere i undersøkelsen. Av disse hadde i underkant av 1000 ikke påført e-postadresse, og en del organisasjoner med e-postadresse kom i retur grunnet problemer med adressene. ${ }^{1}$ Etter flere runder med purring, og utsendelse av invitasjoner per brev hadde vi per 31. oktober 2013 mottatt 952 besvarelser, som danner datagrunnlaget for studien. ${ }^{2}$

De avhengige variablene i studien knytter seg alle til rapportering av bruk av internett og sosiale medier, samt variabler som undersøker oppfattelse av nytte av slik bruk, og hvilke potensielle utfordringer slik bruk har for organisasjonen (fullstendig beskrivelse av variablene finnes $\mathrm{i}$ appendikset bakerst i kapitlet (s_40-45 og s_47)). De uavhengige variablene som benyttes i analysene, er organisasjonens alder (omkodet fra stiftelsesår til aldersgrupper; beskrivelse av organisasjonen (s_o8); organisasjonens medlemmer (s_27 - hovedtyngde for aldersgruppe); og organisasjonskategori).

\section{Omfang, bruksmåter og barrierer for bruk}

I denne delen presenterer vi resultater og diskuterer funn fra analyser som besvarer de første tre forskningsspørsmålene. Først undersøker vi omfanget av bruken, og forskjeller mellom organisasjonene. Deretter studerer vi mer kvalitative aspekter av hva denne bruken handler om, og

$1 \quad$ En mulig kritikk av materialet kan være at det er samlet inn ved hjelp av en web-undersøkelse. Argumentet da ville være at vi har høyere sannsynlighet for å treffe organisasjoner som er aktive på sosiale medier, enn andre organisasjoner, fordi organisasjoner som ikke ønsker å svare på web, eller som vi ikke treffer fordi de ikke har hjemmesider, e-post e.l., ikke kommer med i utvalget. Vi kan ikke utelukke en slik skjevhet i materialet, men har forsøkt å kompensere for det ved å sende ut brev til de organisasjonene vi ikke nådde per e-post. Samtidig antar vi at det er en forsvinnende liten andel av norske nasjonale organisasjoner som ikke har en slik tilstedeværelse, jf. studien til Eimhjellen mfl. av lokale organisasjoners web-tilstedeværelse fra 2010 til 2011(2014, s. 739). Vi anser derfor ikke at det er noen betydelig grad av skjevhet i materialet.

2 Slik vi ser det, er undersøkelsen representativ for kjernepopulasjonen av norske frivillige organisasjoner. Med det menes det at utvalget er representativt for kjernen av aktive eksisterende organisasjoner, nye som gamle og i ulike organisasjonskategorier, altså de organisasjonene der aktiviteten på nasjonalt nivå faktisk foregår. Der hvor undersøkelsen har svakheter, er underskogen av nyere små og sovende eller sporadisk aktive nasjonale organisasjoner. 
hvilke nytteaspekter og utfordringer organisasjonene rapporterer å ha. Her reflekterer vi også over hva som kan være barrierer mot bruk blant organisasjoner som ikke ennå har tatt i bruk sosiale medier.

\section{Omfang av bruk og forskjeller mellom organisasjoner}

Det første, og mest overgripende funnet fra studien er at nasjonale frivillige organisasjoner i Norge i all hovedsak har tatt i bruk internettbaserte kommunikasjonsmidler og sosiale medier (se tabell 1 ). Som vi ser av tabellen, bruker praktisk talt alle organisasjoner e-post og web, og har en egen hjemmeside. Videre er omtrent 2 av 3 organisasjoner til stede på sosiale medie-plattformer, og blant disse har nesten alle en Facebookprofil. 40 prosent av organisasjonene som er til stede på sosiale medier, oppgir å ha en Twitter-profil ( $25 \%$ av total). Det er ikke uventet at bare om lag en av ti organisasjoner oppgir å ha en blogg, som i større grad er en mer personlig uttrykksform.

I den første gruppen av forskningsspørsmål ville vi også vite om det var forskjeller mellom ulike typer av organisasjoner når det gjaldt å ta i bruk disse kommunikasjonsformene. For både e-post, web og hjemmeside er totalandelene så høye at det gir liten mening å skille mellom organisasjoner med ulike kjennetegn (selv om vi skiller på alder og organisasjonstyper, er det små utslag, og alle grupper ligger på godt over 90 prosent). Blogg ser ut til å være så pass lite brukt at vi velger å ikke forfølge analysen av dette. Vi fokuserer derfor på generell bruk av sosiale medier og bruk av Facebook og Twitter når vi nå sammenligner ulike typer av organisasjoner.

Tabell 1: Bruk av internett og sosiale medier blant frivillige organisasjoner. Prosent $(\mathrm{N}=938)$.

\begin{tabular}{|l|l|}
\hline Bruker/ har profil på ... & $\%$ \\
\hline E-post/web & 99 \\
\hline Hjemmeside & 95 \\
\hline Blogg & 11 \\
\hline Sosiale medier & 64 \\
\hline Facebook & 60 \\
\hline Twitter & 25 \\
\hline
\end{tabular}


Tabell 2: Bruk av sosiale medier og beskrivelse av organisasjon. Prosent $(N=927)$.

\begin{tabular}{|l|l|l|l|l|}
\hline & \multicolumn{4}{|c|}{ Organisasjonsbeskrivelse } \\
\hline Bruker/ har profil på ... & Nasjonalledd & Enkeltstående & Paraplyorg. & Annet \\
\hline Sosiale medier & 80 & 54 & 59 & 66 \\
\hline Facebook & 79 & 50 & 53 & 60 \\
\hline Twitter & 35 & 18 & 31 & 26 \\
\hline
\end{tabular}

Basert på de data vi har tilgjengelig, er det mulig å skille mellom organisasjonene på to grunnleggende måter. I datasettet er det spurt om hvilken beskrivelse som passer best på organisasjonen (nasjonalledd med lokale lag; enkeltstående organisasjon; paraplyorganisasjoner; annet), i tillegg til at det er registrert felt hver organisasjon opererer innenfor ( $k u l-$ tur og fritid; velferd; samfunnsrettede; bolig og økonomi; tro og livssyn). Det er ikke uten videre enkelt å stille opp klare forventninger til hvordan organisasjonsbeskrivelsen skulle påvirke tilbøyelighet til å bruke sosiale medier. Likevel finner vi en forventning i litteraturen om at enkeltstående organisasjoner skulle ha mer nytte av sosiale medier enn nasjonalledd, i og med at de mangler omfattende kommunikasjonsstrukturer til lokalt nivå (Arnesen mfl., 2016).

Her peker det seg imidlertid ut klare forskjeller mellom organisasjoner som kjennetegnes av et nasjonalledd med lokale lag, og de andre typene. Disse nasjonalleddene har vesentlig høyere sannsynlighet for å ha tatt i bruk alle de tre typene, mens de enkeltstående organisasjonene med et nasjonalt arbeidsområde er minst tilbøyelige til å ha profiler på sosiale medier. Dette funnet er altså til dels uventet, gitt at fremveksten av enkeltstående organisasjoner med nasjonalt arbeidsområde representerer en ny trend i organisasjonslivet (Arnesen mfl., 2016). En hypotese har vært at sosiale medier har vært med på å muliggjøre en vekst i denne organisasjonstypen. Vår analyse her tyder på at dette ikke er tilfellet. At nasjonalledd med underliggende lokalledd har høyere sannsynlighet for å ta i bruk sosiale medier enn andre organisasjoner, er interessant. En mulig tolkning kan være at nettopp det å ha en etablert, nasjonal medlemsbase, og dermed et etablert nettverk, gjør at den typen nettverkskommunikasjon som sosiale medier legger opp til, fremstår som gunstig. En analyse av befolkningens Facebook-nettverk fra 2013 viste at de aller 
Tabell 3: Bruk av sosiale medier og organisasjonskategori. Prosent. $(N=924)$

\begin{tabular}{|l|l|l|l|l|l|}
\hline & \multicolumn{5}{|c|}{ Organisasjonskategori } \\
\hline $\begin{array}{l}\text { Bruker/ har } \\
\text { profil på ... }\end{array}$ & $\begin{array}{l}\text { Kultur og } \\
\text { fritid }\end{array}$ & Velferd & Samfunnsrett. & Bolig/økonomi & Tro/livssyn \\
\hline Sosiale medier & 62 & 70 & 75 & 52 & 74 \\
\hline Facebook & 59 & 70 & 72 & 47 & 73 \\
\hline Twitter & 16 & 26 & 37 & 21 & 33 \\
\hline
\end{tabular}

fleste hadde flest forbindelser til folk de kjente fra før, enten privat, fra arbeid eller organisasjonsliv (Enjolras et al., 2013). Sosiale medie-nettverk baseres altså ofte på eksisterende offline-nettverk.

Vi undersøkte også sammenhengen mellom hva organisasjonen har som hovedarbeidsområde, og i hvilken grad de bruker sosiale medier (tabell 3). Her er det klare forskjeller mellom organisasjonene, ved at organisasjoner som retter seg mot å påvirke og endre politikk eller mot å bidra innenfor samfunnets tjenesteyting (samfunnsrettede organisasjoner, velferdsorganisasjoner), har klart høyere sannsynlighet for sosial mediebruk enn organisasjoner som er rettet mot medlemmenes private interesser (kultur og fritid, bolig og økonomi). I henhold til Wollebæks typologi over frivillige organisasjoner er det altså de samfunnsrettede, ikke de medlemsrettede som i størst grad tar i bruk digitale virkemidler (2009, s. 37). Tros- og livssynsorganisasjonene har imidlertid også høy sannsynlighet for å bruke sosiale medier, men dette dreier seg om relativt få organisasjoner (66 organisasjoner innenfor denne kategorien i utvalget).

\section{Hva bruker organisasjonene sosiale medier til?}

I undersøkelsen vi gjennomførte, er det stilt 15 spørsmål knyttet til hva organisasjonene bruker sosiale medier til. Vi undersøker først hva de viktigste aktivitetene er. I tabell 4 rapporteres disse resultatene, og vi ser at det er et stort spenn i aktiviteter, fra noe nesten alle gjør (informere medlemmer og markedsføre organisasjonen), til noe under en fjerdedel gjør (gjennomføre aksjoner og skaffe penger). Andre viktige indikatorer er knyttet til informasjon til offentligheten, og å bidra til intern organisasjonsutvikling gjennom innspill fra medlemmer og frivillige. Under 
Tabell 4: Hva bruker organisasjonen sosiale medier til? Prosent. ( $N=595)$

\begin{tabular}{|l|l|}
\hline & $\%$ \\
\hline Informere medlemmene om organisasjonsaktiviteter & 90 \\
\hline Markedsføre og profilere organisasjonen & 78 \\
\hline Informere offentligheten om organisasjonsaktiviteter & 69 \\
\hline Ta imot innspill og forslag fra medlemmer/frivillige & 68 \\
\hline Skape en arena for diskusjon mellom medlemmer/frivillige & 64 \\
\hline Ta imot innspill fra andre enn medlemmer & 53 \\
\hline Skape debatt i offentligheten om saker organisasjonen er opptatt av & 46 \\
\hline Organisere medlemsaktiviteter & 46 \\
\hline Påvirke opinionen eller politikere i bestemte saker & 36 \\
\hline Kontakt med andre organisasjoner & 30 \\
\hline Kontakt med lokallag, fylkeslag & 25 \\
\hline Gjennomføre aksjoner (f.eks. underskriftskampanjer) & 22 \\
\hline Samle inn penger til organisasjonens virke & 14 \\
\hline Selge produkter & 12 \\
\hline
\end{tabular}

halvparten oppgir at det å skape debatt i offentligheten er noe man bruker sosiale medier til, men det må sies å likevel være en viktig aktivitet for organisasjonene, gitt at svært mange kanskje ikke har noen klar relevans for den bredere offentligheten. Vi ser også at over en tredjedel av organisasjonene bruker sosiale medier til å påvirke opinionen eller politikere i bestemte saker.

Analysen i tabell 4 er nyttig for å gi oss et oversiktsbilde av hva nasjonale frivillige organisasjoner bruker sosiale medier til, men sier lite om det finnes et underliggende mønster i disse aktivitetene. Som vi var inne på i teoridelen over, har Lovejoy og Saxton (2012) identifisert tre funksjoner som sosiale medier kan fylle for organisasjoner: information, community, og action. Vi ønsket å se om vi kunne finne de samme dimensjonene i vårt empiriske materiale, og vi gjennomførte derfor en rekke eksplorative faktoranalyser (prinsipal-komponent-analyse) for å se hvordan de ulike variablene opptrer sammen. En faktoranalyse er godt egnet til å vise noen få underliggende dimensjoner basert på en rekke variabler. Vi vil med andre ord få et bilde på hvilke typer av sosiale medier-bruk som henger sammen. Vi presenterer her det vi oppfatter som den beste av disse løsningene. Én av de opprinnelige variablene, å informere medlemmene 
om aktiviteter, ble tatt ut av analysen fordi 90 prosent av organisasjonene oppgir å gjøre dette. Denne variabelen vil derfor bidra til flere av dimensjonene, og tilby lite forklaringskraft. Denne variabelen sammenfaller godt med Lovejoy og Saxtons begrep information (2012), og fordi så mange oppgir å bruke den, kan vi allerede etablere tilstedeværelsen av en slik funksjon av sosiale medier i materialet.

Ut over denne funksjonen fremkommer tre andre dimensjoner ved bruk av sosiale medier gjennom vår analyse. Den første dimensjonen kaller vi 'utadrettet virksomhet'. Denne inneholder variabler som alle på en eller annen måte handler om å informere utad, påvirke opinion og skape debatt i offentligheten. Denne dimensjonen overlapper mest med Lovejoy og Saxtons (2012) community-begrep. Den andre dimensjonen kaller vi 'drift', og her handler det om organisering og informasjon om aktiviteter til medlemmer og frivillige, kontakt med andre deler av organisasjonen og innsamling av midler. Lovejoy og Saxton (2012) har et tilsvarende begrep, action, som også inkluderer blant annet innsamling av midler og oppfordring til handling. Den tredje og siste dimensjonen kaller vi 'organisasjonsutvikling og diskusjon'. Her handler det om å få innspill fra interessenter og å skape en arena for diskusjon mellom medlemmer og frivillige (se appendiks for fullstendig faktorløsning). Lovejoy og Saxton (2012) har ikke noen tilsvarende dimensjon, men Tranvik og Selle (2008) viste i en tidlig kvalitativ studie at ambisjonen om å bruke digitale verktøy til organisasjonsutvikling og diskusjon var tydelig hos frivillige organisasjoner i en svært tidlig fase. Våre funn her tyder på at denne ambisjonen nå i moderat grad er i ferd med å bli oppfylt. Med andre metoder, og med andre utvalg enn de to studiene vi refererer til over, finner vi altså i stor grad et mønster av bruk som ligner. Dette mener vi styrker validiteten til studien som helhet, og dermed også funnene som substansielt viktige.

Vi var så interessert i om det var forskjeller i hvordan de ulike organisasjonstypene brukte sosiale medier. Det er gode grunner til å tro at organisasjoner som er opptatt av velferdsspørsmål, og de mer samfunnsrettede organisasjonene kunne tenkes å ha en mer utadrettet type bruk av sosiale medier enn de andre organisasjonene. For å studere dette foretok vi to typer av analyser. For det første lagde vi enkle boksdiagrammer som viser hvordan de ulike organisasjonskategoriene fordelte seg på de 
tre dimensjonene (vist figur 1-3). Vi foretok også analyser av varians og gjennomsnitt (ANOVA) for å se om organisasjonene skåret signifikant forskjellig på de ulike dimensjonene (disse analysene finnes i appendikset, men kommenteres kort her).

Boksdiagrammene leses på denne måten: Den vertikale aksen viser hvordan organisasjonene innenfor hver gruppe fordeler seg på hva av de tre dimensjonene, o representerer gjennomsnittlig skåre på dimensjonen for organisasjonene sett under ett. Boksen i midten av denne fordelingen representerer hovedtyngden i fordelingen, det vil si de 50 prosentene av organisasjonene som har de midterste verdiene. Streken som enten peker oppover eller nedover, representerer fordelingen for de 25 prosentene som har de laveste og høyeste verdiene. Ser vi for eksempel på organisasjoner innenfor kultur og fritid er altså mer enn 75 prosent av disse organisasjonene under gjennomsnittet for organisasjonene som helhet. Det finnes riktignok en del organisasjoner også innenfor denne kategorien som skårer høyt på utadvendt bruk av sosiale medier, men hovedtendensen er at kultur- og fritidsorganisasjonene er de som i minst grad kjennetegnes av utadrettet bruk. Ser vi derimot på organisasjonene som driver med velferdsspørsmål, de samfunnsrettede, og delvis organisasjonene innenfor bolig og økonomi, er det langt flere av disse organisasjonene som har en utadrettet bruk. Tros- og livssynsorganisasjonene befinner seg på et mellomnivå. Analysen av varians og gjennomsnitt (ANOVA) bekrefter disse funnene, og på tvers av de tre dimensjonene er det innenfor den utadrettede bruken av sosiale medier vi finner størst forskjeller mellom de ulike typene av organisasjoner.

Dette kommer også tydelig til uttrykk når vi undersøker figur 2 og 3. Her ser vi at det er mindre forskjeller, og at organisasjonene i større grad har fordelinger som tydeligere er sentrert rundt gjennomsnittet. For disse dimensjonene er det altså mindre forskjeller i hvordan de ulike typene av organisasjoner bruker sosiale medier. For driftsdimensjonen ser vi imidlertid at organisasjonene fra bolig og økonomi-gruppen har noe lavere bruk, mens tros- og livssynsorganisasjonene har noe høyere bruk. For den siste dimensjonen, diskusjon, er det imidlertid tros- og livssynsorganisasjonene som har lavest slik bruk. 


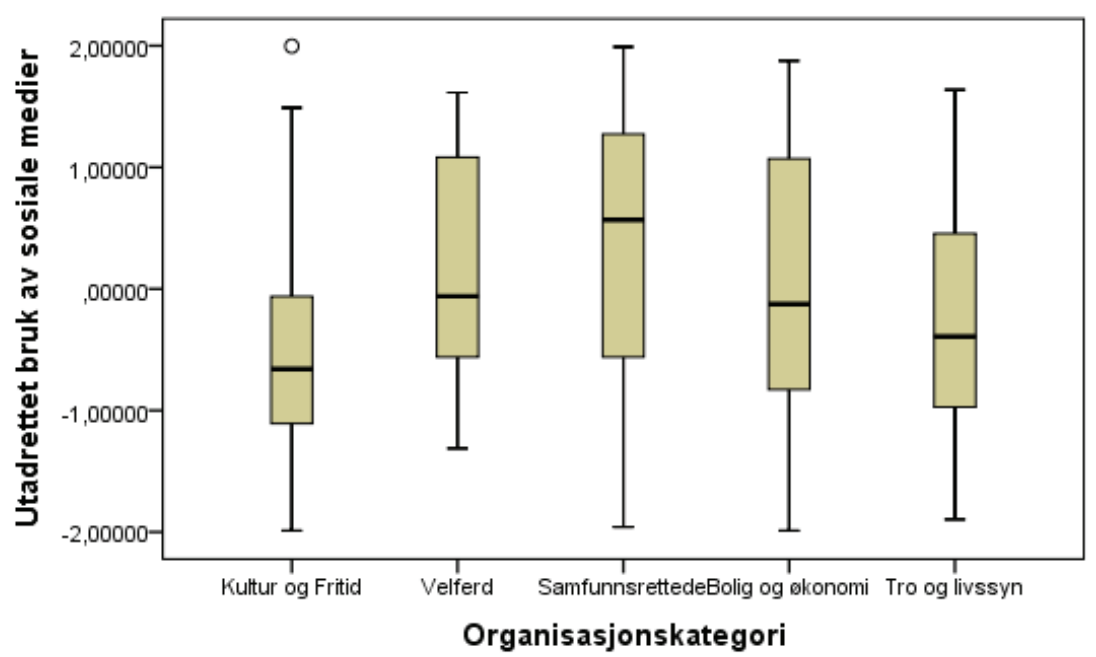

Figur 1

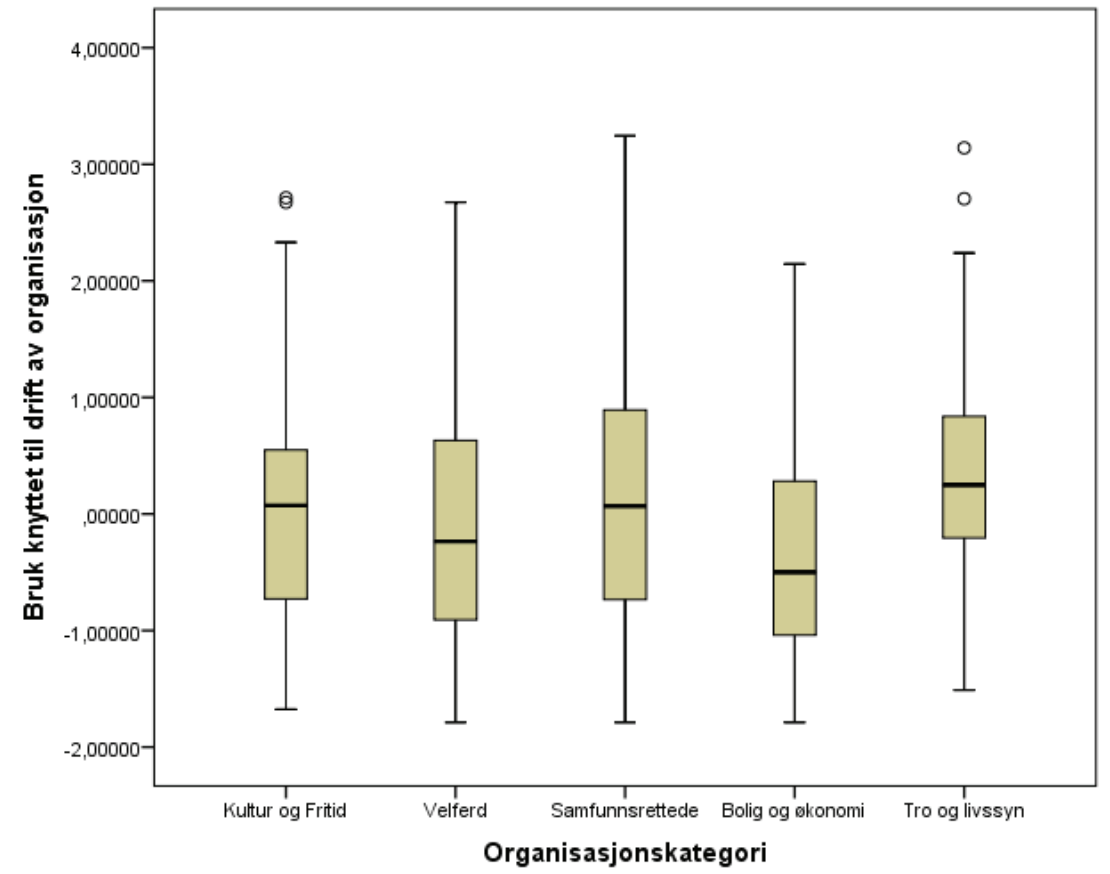

Figur 2 


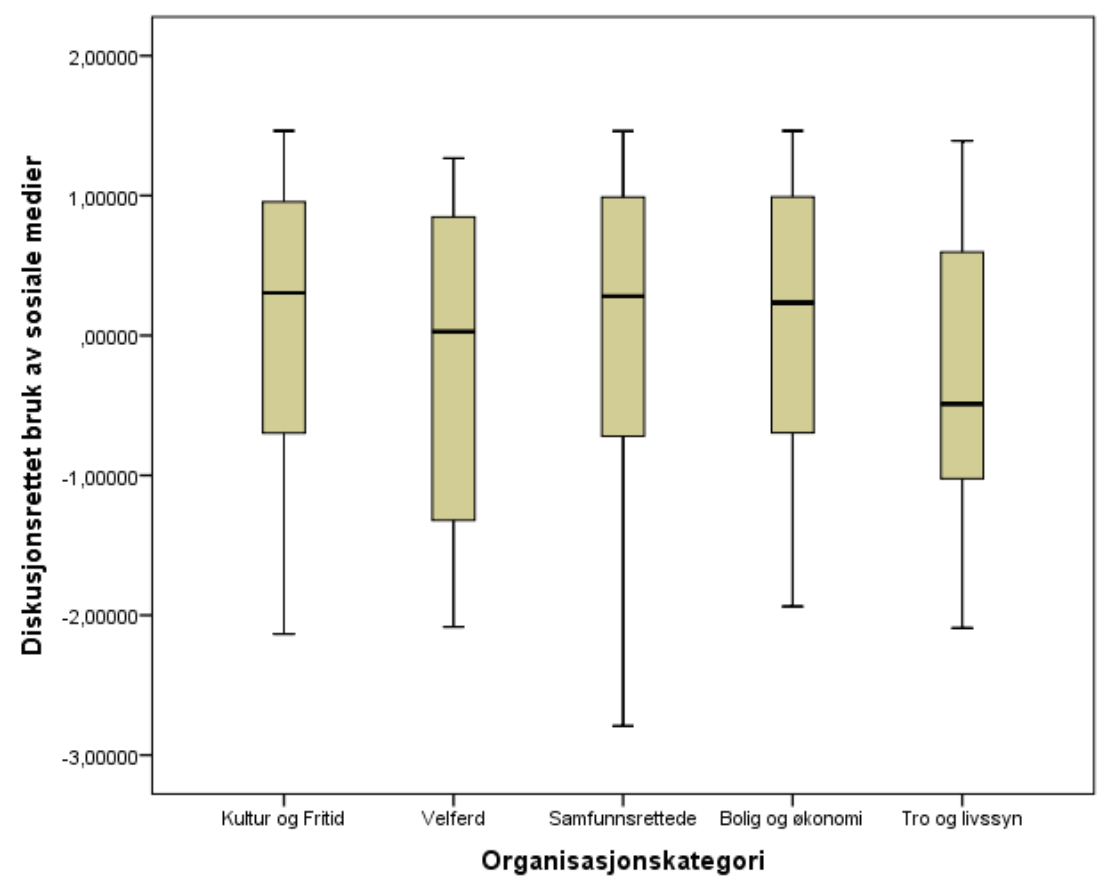

Figur 3

Til slutt er det viktig å påpeke at det er relativt stor variasjon for alle organisasjonstypene, noe som kommer til uttrykk ved at lengden på de vertikale fordelingene er nokså like for alle dimensjoner og alle typer av organisasjoner. Det betyr at det innenfor enhver type av organisasjoner både finnes enkeltorganisasjoner som skårer høyt, og organisasjoner som skårer lavt på dimensjonene. Dette er viktig å ta med seg, og peker på stor heterogenitet.

\section{Utfordringer og nytte knyttet til bruk av sosiale medier - barrierer mot bruk?}

Hvilke utfordringer og nytteaspekter vektlegger organisasjonene når det gjelder sosiale medier? Her sammenligner vi gruppene som sier at de henholdsvis bruker og ikke bruker sosiale medier. ${ }^{3}$ Prosentandelene

3 Antall observasjoner er forskjellig for alle variablene fordi en del organisasjoner av og til lar et spørsmål stå ubesvart. 
Tabell 5: Påstander om sosiale medier. Organisasjoner som bruker og ikke bruker. Prosent.

\begin{tabular}{|l|l|l|}
\hline Påstander om sosiale medier & $\begin{array}{l}\text { Bruker } \\
\text { SoMe }\end{array}$ & $\begin{array}{l}\text { Bruker ikke } \\
\text { SoMe }\end{array}$ \\
\hline A bruke sosiale medier utfordrer medlemsdemokratiet & 30.0 & 32.6 \\
\hline Sosiale medier er effektive informasjonskanaler overfor medlemmer & 87.2 & 75.5 \\
\hline Sosiale medier er effektive informasjonskanaler overfor offentligheten & 69.4 & 62.1 \\
\hline A bruke sosiale medier passer ikke i vår organisasjonskultur & 7.5 & 38.8 \\
\hline $\begin{array}{l}\text { Personer utenfor organisasjonen får for mye innflytelse over } \\
\text { virksomheten }\end{array}$ & 10.0 & 22.3 \\
\hline Å bruke sosiale medier gjør at vi kan påvirke politikken mer effektivt & 43.9 & 35.1 \\
\hline Krever at vi bruker frivillige mer aktivt for å håndtere arbeidsmengden & 35.6 & 52.4 \\
\hline A bruke sosiale medier krever for mye administrative ressurser & 24.7 & 60.5 \\
\hline $\begin{array}{l}\text { Tar oppmerksomheten vekk fra det organisasjonen egentlig skal drive } \\
\text { med }\end{array}$ & 10.2 & 36.3 \\
\hline Å bruke sosiale medier krever en kompetanse vi ikke har & 10.5 & 32.0 \\
\hline $\begin{array}{l}\text { A bruke sosiale medier gjør at fagansatte og kommunikasjonsansatte } \\
\text { må samarbeide tettere }\end{array}$ & 52.1 & 40.9 \\
\hline
\end{tabular}

viser til de som er helt eller delvis enig i utsagnet. Det første det er verdt å merke seg, og som ikke fremgår av tabell 5 , er at organisasjoner som ikke oppgir å bruke sosiale medier, oftere lar en del spørsmål stå ubesvart. Tallgrunnlaget er likevel godt nok til at det er grunn til å stole på resultatene, og at det å sette ubesvart rett og slett betyr at organisasjonen ikke har noen spesifikk mening knyttet til spørsmålet.

Ikke uventet er det klare forskjeller i svarene mellom de to gruppene av organisasjoner. Imidlertid er det interessant å merke seg at påstanden om at bruk av sosiale medier utfordrer medlemsdemokratiet, er relativt lik, og at $i$ underkant av en tredjedel av organisasjonene er enige i dette utsagnet. Dette understreker et viktig trekk ved norsk frivillig organisasjonsliv, nemlig at medlemsdemokratiet tradisjonelt står svært sterkt (Selle, 1993). Selv om alternative former for styring og medvirkning kan tenkes å styrke mulighetene til å engasjere seg for flere, er det likevel en utfordring at slike former er mindre overskuelige når det gjelder hvem som påvirker hvordan (Sørensen \& Torfing, 2007; Enjolras \& Waldahl, 2009).

Det er samtidig verdt å merke seg at blant organisasjoner som ikke bruker sosiale medier, er det fortsatt en overveiende majoritet som mener at det ville være effektive informasjonskanaler overfor både medlemmer 
og offentligheten for øvrig. Det er i det hele tatt mest interessante svar å finne i gruppen som ikke bruker sosiale medier. Over halvparten av dem mener for eksempel at slik bruk ville kreve mer aktiv bruk av frivillige, mens 60 prosent sier at det krever for mye administrative ressurser.

Når det gjelder sammenhenger mellom organisasjonstyper (alder, beskrivelse, kategori) og svarene på påstandene over, viser en sammenligning av gjennomsnittene for de ulike gruppene at det ikke er svært store forskjeller. Det kan imidlertid se ut som om de digitalt innfødte, og de organisasjonene som er mer samfunnsrettede (velferd, samfunnsrettet), ser noe mer positivt på bruk av sosiale medier enn de andre.

Fra analysene knyttet til det første forskningsspørsmålet, husker vi at om lag en tredjedel av organisasjonene oppga å ikke bruke sosiale medier. Vi fant noen forskjeller mellom organisasjonene i så måte, og vi skal nå undersøke hva de viktigste grunnene til å la være å bruke sosiale medier synes å være. Datagrunnlaget for disse analysene er derfor de 332 organisasjonene som ikke bruker sosiale medier. Det er verdt å merke seg at så mye som mellom 35 og 45 prosent av de 332 organisasjonene velger å la dette spørsmålet stå ubesvart, og resultatene må derfor tolkes med dette i mente (prosentandelen som oppgis, er summen av de som har svart svært viktig og nokså viktig årsak).

De to klart viktigste årsakene ser ut til å være knyttet til ressurser. Om lag 40 prosent av organisasjonene svarer at det enten tar for mye tid, eller at de ikke har ressurser til en langsiktig satsning på sosiale medier. Andre viktige faktorer er også ressursorienterte: 24 prosent mener de mangler kompetanse i administrasjonen, mens 20 prosent oppgir at de mangler penger og utstyr. Like viktig er imidlertid også en helt annen type begrunnelse, 24 prosent sier nemlig at organisasjonene ikke ser nytten av å bruke sosiale medier, mens 20 prosent sier at det å bruke sosiale medier ikke passer til organisasjonens profil. Det er altså langs disse to hoveddimensjonene - mangel på ressurser og mangel på nytte/ identifisering med organisasjonsprofil - at de viktigste årsakene finnes. En siste dimensjon er knyttet til frykt for å ikke kunne kontrollere det som sies om organisasjonen i sosiale medier; 13 prosent av organisasjonene oppgir dette som en viktig årsak til at de ikke bruker sosiale medier. 
Begge disse hovedårsakene til å ikke ta $\mathrm{i}$ bruk sosiale medier samsvarer med funn fra tidligere studier. I den kvalitative studien av tre nasjonale frivillige organisasjoner fant Steen-Johnsen mfl. (2012) at organisasjonene opplevde at det å lykkes i sosiale medier krevde en kompetanse de i utgangspunktet ikke hadde. Med små eller ingen kommunikasjonsressurser ble utviklingsarbeidet tungt. I tillegg opplevde de stor konkurranse om oppmerksomheten i sosiale medier, ikke minst fra kommersielle aktører. Også problemstillingen knyttet til organisasjonsprofil og identitet sto sentralt i organisasjonenes diskusjon om bruken av sosiale medier. For eksempel påpekte den internasjonale menneskerettighetsorganisasjonen som var med i studien, at de tradisjonelt var konstruert rundt top-down-informasjon fra hovedkontoret, som bestemte hvilke saker som skulle tas opp, ut til medlemmene. Å åpne opp for sosiale medier kunne føre til uklarhet og usikkerhet i kommunikasjonen av viktige saker.

\section{Digitalt innfødte organisasjoner}

Til slutt ser vi på forskjeller mellom digitalt innfødte organisasjoner, og andre typer av organisasjoner. De digitalt innfødte er etablert fra 2006 og utover, og har dermed eksistert fra omtrent den tiden da Facebook ble tilgjengelig i Norge (2006). Disse organisasjonene utgjør om lag 10 prosent av det totale utvalget av organisasjoner i vår undersøkelse. Det er gode grunner til å anta at organisasjoner som er etablert i denne perioden, har tatt i bruk sosiale medier i større grad enn eldre organisasjoner. For det første fordi organisasjonsstrukturen er etablert i en periode da inkorporering av sosiale medier i virksomheten kunne skje som en del av den naturlige etableringen av organisasjonen. Med andre ord kunne verktøyene som kunne muliggjøre andre måter å strukturere en organisasjon på, være med og legge premisser for virksomhetene allerede fra starten av. Dette er i motsetning til eldre organisasjonstyper, der bruken av sosiale medier måtte integreres i en allerede satt struktur. For det andre kan man tenke seg at organisasjonene til en viss grad er oppstått som en direkte eller indirekte konsekvens av de muligheter som sosiale medier gir for å organisere frivillighet (Bennett \& Segerberg, 2012). 
Før vi ser nærmere på forskjellene mellom de digitalt innfødte og de andre når det gjelder bruk av og oppfatninger om sosiale medier, gir vi en kort oversikt over hvordan disse to typene av organisasjoner skiller seg når det gjelder organisasjonsbeskrivelse (nasjonalledd med lokale lag, enkeltstående med nasjonalt arbeidsområde, paraplyorganisasjon), organisasjonskategori (kultur og fritid, velferd, samfunnsrettede, bolig og økonomi, tro og livssyn) samt medlemsantall. Vi husker at det er viktige forskjeller mellom organisasjonene innenfor de ulike feltene når det gjelder i hvilken grad de tar i bruk sosiale medier. Nasjonalledd med lokale lag var mer tilbøyelige enn andre organisasjoner til å ta i bruk sosiale medier, og velferds- og samfunnsrettede organisasjoner hadde også en større andel organisasjoner som hadde tatt i bruk sosiale medier. Av de digitalt innfødte organisasjonene var imidlertid bare 21 prosent karakterisert som nasjonalledd med lokale lag, mens den tilsvarende andelen for alle de andre organisasjonene var 32 prosent. Dette peker altså på at eventuell overrepresentasjon av digitalt innfødte organisasjoner når det gjelder bruk av sosiale medier, ikke kan føres tilbake til at de også er overrepresentert i denne kategorien av organisasjoner, tvert om. Når det gjelder hva det er organisasjonene driver med, ser vi imidlertid et annet mønster, ved at digitalt innfødte er noe overrepresentert sammenlignet med andre organisasjoner når det gjelder velferd (11 prosent mot 7 prosent), og særlig når det gjelder samfunnsrettede organisasjoner (51 prosent mot 28 prosent). Disse organisasjonstypene er også de som har størst tilbøyelighet til å ha tatt i bruk sosiale medier, og det at de digitalt innfødte er overrepresentert i disse kategoriene, kan være med på å forklare noe av forskjellene mellom digitalt innfødte og andre organisasjoner.

For både sosiale medier generelt og for Facebook og Twitter spesielt har digitalt innfødte organisasjoner en større tilbøyelighet til å ha tatt dette i bruk enn de andre organisasjonene (se tabell 6), i tråd med de forventningene vi hadde.

Tabell 6: Bruk av sosiale medier, digitalt innfødte og andre

\begin{tabular}{|l|l|l|}
\hline Bruker/ har profil på ... & Digitalt innfødte & Andre \\
\hline Sosiale medier & $72 \%$ & $63 \%$ \\
\hline Facebook & $69 \%$ & $59 \%$ \\
\hline Twitter & $30 \%$ & $25 \%$ \\
\hline
\end{tabular}


Dersom vi ser på sammenhengen mellom organisasjonsbeskrivelse (nasjonalledd, enkeltstående, paraplyorg.) og bruk av sosiale medier for de digitalt innfødte og de andre organisasjonene hver for seg, ser vi også at mer eller mindre det samme mønsteret avtegner seg. De digitalt innfødte har høyere tilbøyelighet til å bruke sosiale medier, men det er fortsatt de enkeltstående organisasjonene som også her er minst tilbøyelige til å bruke det, med unntak for Twitter, der de digitalt innfødte organisasjonene som karakteriseres som enkeltstående, har nesten like høy bruk som paraplyorganisasjoner, og høyere enn nasjonalleddene.

Til slutt ser vi også nærmere på hvilken rolle medlemsantall og antall ansatte har når det gjelder bruk av sosiale medier, for både de digitalt innfødte og de andre organisasjonene. De digitalt innfødte har vesentlig færre medlemmer enn de andre organisasjonene, og det gir derfor liten mening å vurdere de absolutte tallene opp mot hverandre. Vi ser i stedet på om det er slik at forholdet mellom de som bruker og ikke bruker sosiale medier blant de forskjellige organisasjonene når det gjelder gjennomsnittlig antall medlemmer og ansatte, er det samme for de digitalt innfødte og de andre organisasjonene. De digitalt innfødte organisasjonene hadde om lag 87 medlemmer i gjennomsnitt, mens de andre hadde 2400 medlemmer. For de digitalt innfødte organisasjonene hadde organisasjoner som oppga å ha tatt i bruk sosiale medier generelt og Facebook generelt, litt over dobbelt så mange medlemmer som de som ikke hadde tatt i bruk dette. For de andre organisasjonene hadde organisasjoner som oppga å ha tatt i bruk sosiale medier, om lag fem ganger så mange medlemmer som de som ikke hadde gjort dette. Størrelsen på medlemsmassen betyr altså mer for de eldre organisasjonene enn for de digitalt innfødte. For Twitter ser vi et annet mønster, der de eldre organisasjonene fortsatt har en svært sterk effekt av antall medlemmer (omtrent fire ganger så mange medlemmer i organisasjoner som har tatt i bruk Twitter), finnes ingen slik effekt hos de digitalt innfødte. Disse funnene peker altså i retning av at strukturelle trekk som medlemsmasse betyr mindre for digitalt innfødte enn for andre organisasjoner.

Når det gjelder heltidsansatte i organisasjonen, er det også forskjeller, ved at de eldre organisasjonene i gjennomsnitt har 1,2 heltidsansatte, mens de digitalt innfødte har omtrent en halv ansatt. For de eldre 
organisasjonene har de som har nevnt at de bruker sosiale medier generelt, og Facebook og Twitter spesielt, om lag tre ganger så mange ansatte som de organisasjonene som ikke har tatt dette i bruk. For de digitalt innfødte, derimot, ser vi bare en tilsvarende trend for Twitter, mens det er mindre forskjeller for sosiale medier generelt og Facebook spesielt. Ressurser i form av både medlemmer og ansatte ser altså ut til å bety en del mindre for de digitalt innfødte organisasjonene enn det gjør for de organisasjonene som oppstod før sosiale medier ble tilgjengelige kommunikasjonsverktøy.

Dette funnet ser altså ut til å peke på at organisasjoner som har oppstått i den perioden da sosiale medier har vokst frem som en viktig kommunikasjonsform, tar i bruk slike verktøy på en mer naturlig, eller selvfølgelig, måte enn det andre organisasjoner gjør. Ikke bare er det en større andel av digitalt innfødte organisasjoner som bruker slike verktøy enn andre organisasjoner, de trenger også færre ressurser for å gjøre det. Selv om det fortsatt er slik at organisasjoner med flere medlemmer og ansatte oftere oppgir å ha tatt i bruk sosiale medier, er ikke forskjellene så store i gruppen av digitalt innfødte organisasjoner. Dette kan tyde på at organisasjoner som faktisk har nytte av sosiale medier, kan ta dem i bruk på en enklere måte enn det mer tradisjonelle organisasjoner kan. Det vil bli svært interessant å følge denne utviklingen i fremtidige undersøkelser av de frivillige organisasjonenes bruk av ulike kommunikasjonsverktøy.

\section{Diskusjon og begrensninger}

Denne første norske studien av hvordan nasjonale frivillige organisasjoner bruker sosiale medier, viser at disse organisasjonene bruker sosiale medier i forholdsvis stor grad, til en rekke ulike formål. Vi har skilt mellom tre hovedgrupper av formål - ekstern påvirkning, drift og organisasjonsutvikling og diskusjon - og vist at elementer av alle disse forekommer i ganske høy grad. I forhold til eksisterende forskning, som har understreket at frivillige organisasjoner er etternølere i bruk av sosiale medier (Asencio \& Sun, 2015; Bortree \& Seltzer, 2009; Eimhjellen et al., 2014), viser altså denne studien at norske frivillige organisasjoner tar $\mathrm{i}$ bruk og utnytter sosiale medier som ressurser, og at bruken ikke bare 
retter seg mot eksterne formål, men også i høy grad mot interne formål. En mulig forklaring på at vi finner mer ustrakt bruk enn det andre studier har vist, kan være at noen av disse studiene er forholdsvis gamle og dermed belyser bruk av digitale medier i en svært tidlig fase. En annen forklaring kan handle om at vi her studerer nasjonale organisasjoner, som både kan tenkes å ha større ressurser og større interesse i å ta i bruk nye medier. Samtidig må vi minne om at vår egen studie, som er fra 2013, også beskriver en forholdsvis tidlig fase i utviklingen av web 2.o. I dette feltet skjer utviklingen fort, og dermed har også vår studie sine begrensninger.

Vårt grunnleggende teoretiske perspektiv på bruken av sosiale medier i frivillige organisasjoner er at organisasjoners struktur, tradisjoner og formål vil legge premisser for den bruken organisasjoner kan gjøre seg av disse kommunikasjonsmidlene. Vi har sett at velferdsorganisasjoner, samfunnsrettede organisasjoner og tros- og livssynsorganisasjoner tar i bruk sosiale medier i større grad enn kultur- og fritidsorganisasjoner og organisasjoner rettet mot bolig og økonomi. En mulig tolkning av dette er at de førstnevnte organisasjonene har større behov for og nytte av å kommunisere med offentligheten, og at sosiale medier kan være viktige verktøy i å nå bredt ut.

Samtidig tyder ikke analysene våre på at det å nå ut i offentligheten er en drivkraft alene. Et interessant funn er at nasjonale organisasjoner med lokale ledd bruker sosiale medier mer enn enkeltstående organisasjoner og paraplyorganisasjoner. Dette er organisasjoner som stort sett er basert på lokale medlemmer. Å informere medlemmer om organisasjonsaktiviteter er også den mest gjennomgående bruksmåten på tvers av organisasjoner, og det å ta imot innspill fra medlemmer eller diskutere organisasjonsforhold er også fremtredende. Her ser det altså ut til at organisasjonene utnytter det interaktive potensialet i sosiale medier.

To sett med faktorer peker seg ut blant organisasjoner som ikke har tatt i bruk sosiale medier: mangel på ressurser og en frykt for at bruk av sosiale medier kan gå ut over organisasjonens profil og identitet. Vi har ikke undersøkt spørsmålet om betydningen av ressurser i dybden her, men den siste delen av analysen antyder at både antall ansatte og antall medlemmer har betydning for organisasjoners sosiale medier-bruk. Slik sett gir denne studien støtte til en hypotese om at digitalisering kan føre 
til en «rike blir rikere»-effekt, det vil si at organisasjoner som allerede er ressurssterke, er de som best utnytter potensialet i nye virkemidler, noe som fører til at de styrker sin posisjon (Easley \& Kleinberg, 2010; Eimhjellen, 2014a; Norris, 2001). Samtidig viser vår studie også at denne typen ressurser spiller mindre rolle for bruken til organisasjonene vi har kalt «digitalt innfødte». Dette tyder på at digitaliseringen også skaper rom for at nye organisasjoner kan etablere seg og vokse, på andre premisser enn de tradisjonelle. En problemstilling som er verdt å forfølge nærmere, er hvordan nye organisasjoner integrerer digitale medier som del av sin organiseringsform og -struktur (Bennett \& Segerberg, 2012). Opplagte eksempler på dette er ad hoc-organisasjonene som oppsto i forbindelse med flyktningkrisen i 2015 (se Sætrangs kapittel i denne boken), men antagelig finnes det varianter som ligger nærmere tradisjonelle organisasjonsformer, men som likevel integrerer sosiale medier på mer selvsagte måter enn hva tradisjonelle organisasjoner kan få til.

Barrierer knyttet til ressurser og organisasjonsidentitet er ikke unike for frivillige organisasjoner, men kanskje settes utfordringene på spissen hos frivillige organisasjoner, som både kan ha knapt med ressurser i form av ansatte, og som er avhengige av å ivareta en organisasjonsidentitet med tanke på å mobilisere og bevare frivillige. Vi ser en gjenklang av slike bekymringer i våre data, men det er interessant og viktig til slutt å påpeke at det er en betydelig forskjell på hvordan de organisasjonene som har tatt i bruk sosiale medier, og de som ikke har tatt dem i bruk, bedømmer disse utfordringene. Det faktum at brukerne av sosiale medier bedømmer utfordringene som mindre, kan tyde på at dette først og fremst handler om en terskel som må overskrides.

Med tanke på bokens overordnede tema - nye former for kollektiv handling - peker denne studien i retning av at digitaliseringen har bidratt til å styrke kapasiteten til frivillige organisasjoner når det gjelder å kommunisere med offentligheten og med sine medlemmer. Det er med andre ord ikke slik at vi har fătt et brudd i de tradisjonelle organisasjonenes evne til å mobilisere til og organisere kollektiv handling. Snarere kan vi anta at denne evnen er blitt styrket ved at organisasjonene faktisk tar digitale verktøy i bruk, selv om vi ut fra våre data ikke kan si noe om effekten av denne bruken av sosiale medier. Funnene kan også tyde på at 
digitaliseringen kan føre med seg noen strukturelle endringer i sektoren, ved at forskjellen mellom ressurssterke og mindre ressurssterke organisasjoner øker med tanke på kommunikasjonskapasitet. Vi har også pekt på at det kan finnes rom for at nye typer organisasjoner vokser frem, der digitale medier blir en mer integrert del av virksomheten fra begynnelsen.

Denne studien har noen begrensninger, ikke minst at man kan anta at det har skjedd stor utvikling i bruken av sosiale medier i det frivillige organisasjonsfeltet siden 2013. Vi ser derfor frem til at resultatene i denne studien utfordres av nyere studier, foretatt i perioden der sosiale medier har modnet både når det gjelder bruk og teknologisk utvikling. Det er også en utfordring at datamaterialet inneholder stor variasjon, og det er dermed vanskelig å systematisere funnene. Likevel mener vi det er av stor verdi å få et beskrivende bilde av bruken i et bredt felt av nasjonale frivillige organisasjoner, og at det vil bli viktig å følge denne utviklingen over tid.

\section{Referanser}

Arnesen, D., Sivesind, K.H., \& Gulbrandsen, T. (2016). Fra medlemsbaserte organisasjoner til koordinert frivillighet? Det norske organisasjonssamfunnet fra 1980 til 2013. Rapport 5. Bergen/Oslo: Senter for forskning på sivilsamfunn og frivillig sektor.

Asencio, H., \& Sun, R. (2015). Cases on Strategic Social Media Utilization in the Nonprofit Sector. Hershey, PA: IGI Global.

Benkler, Y. (2006). The Wealth of Networks - How Social Production Transforms Markets and Freedom. New Haven/London: Yale University Press.

Bennett, W.L., \& Segerberg, A. (2012). The logic of connective action: Digital media and the personalization of contentious politics. Information, Communication and Society, 15(5), 739-768. doi:10.1080/1369118X.2012.670661

Bortree, D.S., \& Seltzer, T. (2009). Dialogic strategies and outcomes: An analysis of environmental advocacy groups' Facebook profiles. Public Relations Review, 35(3), 317-319. doi:10.1016/j.pubrev.2009.05.002

Dahlgren, P. (2009). Media and political engagement : citizens, communication, and democracy. Cambridge: Cambridge University Press.

Easley, D., \& Kleinberg, J. (2010). Networks, crowds, and markets : reasoning about a highly connected world. New York: Cambridge University Press.

Eimhjellen, I., Wollebæk, D., \& Strømsnes, K. (2014). Associations Online: Barriers for Using Web-Based Communication in Voluntary Associations. Voluntas: 
International Journal of Voluntary and Nonprofit Organizations, 25(3), 730-753. doi:10.1007/s11266-013-9361-x

Eimhjellen, I.S. (2014a). From face-to-face to Facebook?: web technologies in Norwegian civil society (Ph.d.). Bergen: University of Bergen.

Eimhjellen, I.S. (2014b). Internet Communication: Does It Strengthen Local Voluntary Organizations? Nonprofit and Voluntary Sector Quarterly, 43(5), 890909. doi:10.1177/0899764013487996

Enjolras, B., Karlsen, R., Steen-Johnsen, K., \& Wollebæk, D. (2013). Liker - Liker ikke. Sosiale medier, samfunnsengasjement og offentlighet. Oslo: Cappelen Damm Akademisk.

Enjolras, B., \& Waldahl, R. H. (2009). Idrettsdemokratiet: makt og styring i idretten. Oslo: Akilles.

Greenberg, J., \& Macaulay, M. (2009). NPO 2.o? Exploring the Web Presence of Environmental Nonprofit Organizations in Canada. Global Media Journal, 2(1), 63.

Guo, C., \& Saxton, G. D. (2014). Tweeting Social Change. Nonprofit and Voluntary Sector Quarterly, 43(1), 57-79. doi:10.1177/0899764012471585

Larsson, A.O., \& Kalsnes, B. (2014). 'Of course we are on Facebook': Use and nonuse of social media among Swedish and Norwegian politicians. European Journal of Communication, 29(6), 653-667. doi:10.1177/0267323114531383

Larsson, A.O., Kalsnes, B., \& Christensen, C. (2017). Elite Interaction: Public service broadcasters' use of Twitter during national elections in Norway and Sweden. Journalism Practice, 11(9), 1137-1157. doi:10.1080/17512786.2016.1234943

Lovejoy, K., \& Saxton, G.D. (2012). Information, Community, and Action: How Nonprofit Organizations Use Social Media. Journal of Computer-Mediated Communication, 17(3), 337-353. doi:10.1111/j.1083-6101.2012.01576.x

Norris, P. (2001). Digital divide: civic engagement, information poverty, and the Internet worldwide. Cambridge: Cambridge University Press.

Selle, P. (1993). Voluntary organisations and the welfare state: The case of Norway. Voluntas: International Journal of Voluntary and Nonprofit Organizations, 4(1), $1-15$.

Steen-Johnsen, K., Enjolras, B., \& Kruse, A. E. (2012). Nettverkssamfunn og frivillige organisasjoner. I T. Tranvik \& P. Selle (2008). Digital teknologi i sivilsamfunnet : studier av fire frivillige organisasjoner. Oslo: Unipub.

Sørensen, E., \& Torfing, J. (2007). Theories of democratic network governance. Basingstoke: Palgrave Macmillian.

Wollebæk, D. (2009). Change in Local Voluntary Associations. (PhD.), University of Bergen, Bergen.

Wollebæk, D., \& Selle, P. (2008). A social democratic model of civil society? I B. Jobert \& B. Kohler-Koch (Red.), Changing Images of Civil Society: From Protest to Governance. London: Routledge. 


\section{Appendiks}

\begin{tabular}{|l|l|l|l|}
\hline \multicolumn{2}{|c|}{ Prinsipal komponentanalyse } & \multicolumn{2}{|c|}{ Komponent } \\
\hline & \multicolumn{1}{|c|}{$\mathbf{3}$} \\
\hline & $\mathbf{2}$ & $\mathbf{2}$ \\
\hline Informere offentligheten om organisasjonsaktiviteter &, 580 &, 027 &, 088 \\
\hline Ta imot innspill og forslag fra medlemmer og/eller frivillige &,,- 008 &, 148 &, 828 \\
\hline Ta imot innspill og forslag fra andre enn medlemmer &, 278 &, 100 &, 744 \\
\hline $\begin{array}{l}\text { Skape en arena for diskusjon mellom medlemmer og/eller } \\
\text { frivillige }\end{array}$ &, 085 &, 054 &, 664 \\
\hline Organisere medlemsaktiviteter &,- 080 &, 683 &, 321 \\
\hline Lage arrangementer og sende ut invitasjoner &, 008 &, 615 &, 222 \\
\hline Gjennomføre aksjoner (f.eks. underskriftskampanjer) &, 503 &, 427 &, 084 \\
\hline Kontakt med lokallag, fylkeslag &, 111 &, 561 &, 153 \\
\hline Kontakt med andre organisasjoner &, 342 &, 455 &, 313 \\
\hline Samle inn penger til organisasjonens virke &, 249 &, 498 &,- 058 \\
\hline Selge produkter &, 099 &, 560 &,- 168 \\
\hline opptatt av &, 809 &, 061 &, 102 \\
\hline Markedsføre og profilere organisasjonen &, 898 &, 197 &, 075 \\
\hline Påvirke opinionen eller politikere i bestemte saker &, 043 &, 037 \\
\hline
\end{tabular}




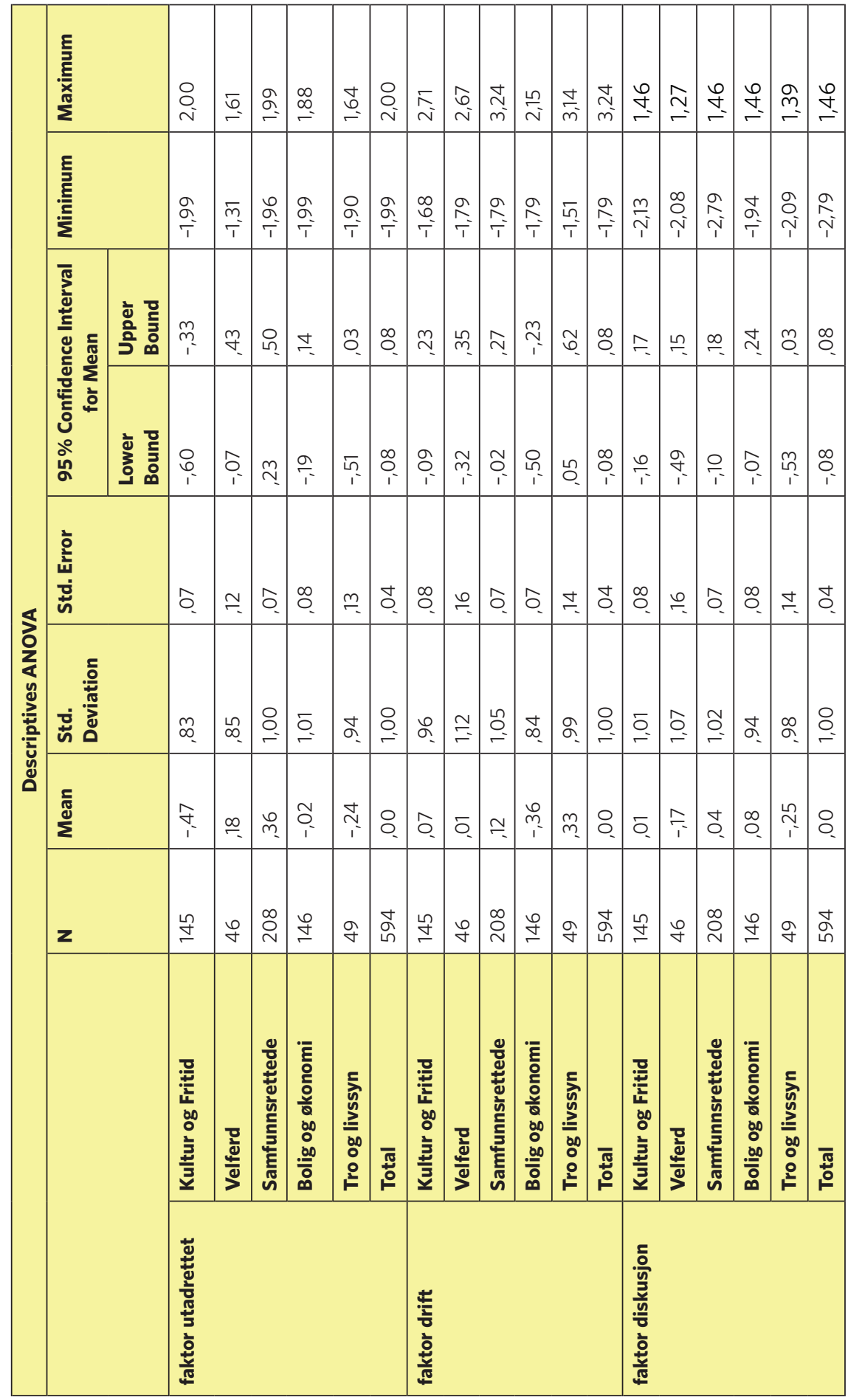




\begin{tabular}{|c|c|c|c|c|c|c|}
\hline \multicolumn{7}{|c|}{ ANOVA } \\
\hline & & $\begin{array}{l}\text { Sum of } \\
\text { Squares }\end{array}$ & df & $\begin{array}{l}\text { Mean } \\
\text { Square }\end{array}$ & $\mathbf{F}$ & Sig. \\
\hline \multirow[t]{3}{*}{ faktor utadrettet } & Between Groups & 63,458 & 4 & 15,864 & 17,662 &, 000 \\
\hline & Within Groups & 529,051 & 589 &, 898 & & \\
\hline & Total & 592,509 & 593 & & & \\
\hline \multirow[t]{3}{*}{ faktor drift } & Between Groups & 28,924 & 4 & 7,231 & 7,537 &, 000 \\
\hline & Within Groups & 565,067 & 589 &, 959 & & \\
\hline & Total & 593,991 & 593 & & & \\
\hline \multirow[t]{3}{*}{ faktor diskusjon } & Between Groups & 5,853 & 4 & 1,463 & 1,471 & 209 \\
\hline & Within Groups & 585,947 & 589 & ,995 & & \\
\hline & Total & 591,801 & 593 & & & \\
\hline
\end{tabular}

Variabler fra spørreskjema:

s_08

Hvilken beskrivelse passer best på deres organisasjon?

1: Nasjonalledd med lokale og/eller regionale lag eller avdelinger

3: Enkeltstående organisasjon med nasjonalt arbeidsområde

4: Paraplyorganisasjon med tilsluttede nasjonale organisasjoner

5: Annet, spesifiser

s_27

Organisasjonens medlemmer

Aldersgruppe for hovedtyngden av medlemmene

1: Opp til 15 år

2: $16-30$ år

3: 31-50 år

4: 51-66 år

5: Over 67 år

6: Vet ikke

s_40

Internett

Bruker organisasjonen eller ledelsen internettverktøy (e-post eller web) i forbindelse med organisasjonsarbeidet?

1: Ja

2: $\mathrm{Nei}$ 
s_41- HVIS s_40 =1

Internett

Webtjenester som benyttes

1: Hjemmeside ${ }^{\star *}$ (Skriv inn nettadresse:)

2: Blogg ${ }^{* *}($ Skriv inn nettadresse:)

3: Sosiale medier

4: RSS - nyhetsoppdatering

5: Annet ${ }^{* *}$ (Spesifiser:)

6: Ingen av delene

s_42-HVIS s_41=3

Internett

Har profil på

1: Facebook

2: Twitter

3: LinkedIn

4: YouTube

5: Flickr

6: Origo

7: MySpace

8: Google +

9: Instagram

10: Wikipedia

11: Andre ...**(Spesifiser:)

12: Ingen av delene

s_43 - HVIS s_41=3

Internett

Hva bruker organisasjonen sosiale medier til?

1: Informere medlemmene om organisasjonsaktiviteter

2: Informere offentligheten om organisasjonsaktiviteter

3: Ta imot innspill og forslag fra medlemmer og/eller frivillige

4: Ta imot innspill og forslag fra andre enn medlemmer

5: Skape en arena for diskusjon mellom medlemmer og/eller frivillige 
6: Organisere medlemsaktiviteter

7: Lage arrangementer og sende ut invitasjoner

8: Gjennomføre aksjoner (f.eks. underskriftskampanjer)

9: Kontakt med lokallag, fylkeslag

10: Kontakt med andre organisasjoner

11: Samle inn penger til organisasjonens virke

12: Selge produkter

13: Skape debatt i offentligheten om saker organisasjonen er opptatt av

14: Markedsføre og profilere organisasjonen

15: Påvirke opinionen eller politikere i bestemte saker

16: Ingen av delene

s_44 - HVIS s_40 =1

Internett

Nytte av internett

1: Informere medlemmene om organisasjonsaktiviteter

2: Skape sterkere kontakt mellom nasjonalleddet og medlemmene

3: Skape sterkere kontakt mellom nasjonalledd og lokallag/fylkeslag

4: Øke medlemsinnflytelsen i organisasjonen

5: Skape demokratisk debatt om organisasjonssaker

6: Organisere interne og eksterne organisasjonsaktiviteter

7: Gjennomføre aksjoner

8: Inntektsgenerering

9: Skape debatt i offentligheten om saker organisasjonen er opptatt av

10: Markedsføre og profilere organisasjonen

11: Påvirke opinionen eller politikere i bestemte saker

12: Påvirke utfallet av bestemte politiske saker

1: Svært nyttig

2: Nokså nyttig

3: Ikke særlig nyttig

4: Ikke nyttig i det hele tatt

5: Ubesvart 
s_45 - HVIS s_40=1 \& s_41 ikke lik 3

Internett

Årsak til å ikke bruke sosiale medier

1: Vi ser ikke nytten av det

2: Det tar for mye tid

3: Vi mangler penger eller utstyr

4: Vi mangler kompetanse i administrasjonen

5: Vi har forsøkt tidligere, men fant ut at det ikke var effektivt for oss

6: Å bruke sosiale medier passer ikke med vår organisasjonsprofil

7: Vi synes det er vanskelig å kontrollere det som sies om oss i sosiale medier

8: Vi mener vi ikke har ressurser til en langsiktig satsning på sosiale medier

1: Svært viktig årsak

2: Nokså viktig årsak

3: Mindre viktig årsak

4: Ingen årsak

5: Ubesvart

s_47

Internett

Her følger noen påstander om bruken av sosiale medier. Kan du for hver av påstandene markere om du er helt enig, delvis enig, verken enig eller uenig, delvis uenig eller helt uenig?

1: Å bruke sosiale medier utfordrer medlemsdemokratiet

2: Sosiale medier er effektive informasjonskanaler overfor medlemmer

3: Sosiale medier er effektive informasjonskanaler overfor offentligheten

4: Å bruke sosiale medier passer ikke i vår organisasjonskultur

5: Personer utenfor organisasjonen får for mye innflytelse over virksomheten

6: Å bruke sosiale medier gjør at vi kan påvirke politikken mer effektivt

7: Tar oppmerksomheten vekk fra det organisasjonen egentlig skal drive med 
8: Krever at vi bruker frivillige mer aktivt for å håndtere arbeidsmengden 9: $\AA$ bruke sosiale medier krever for mye administrative ressurser 10: $\AA$ bruke sosiale medier krever en kompetanse vi ikke har 11: Å bruke sosiale medier gjør at fagansatte og kommunikasjonsansatte må samarbeide tettere
1: Helt enig
2: Delvis enig
3: Verken enig eller uenig
4: Delvis uenig
5: Helt uenig
6: Ubesvart 



\title{
Nye former for tilhørighet. Migrantorganisasjoner for barn og ungdom i en norsk sivilsamfunnskontekst
}

\author{
Guro Ødegård
}

OsloMet - storbyuniversitetet

\section{Marianne Takle}

OsloMet - storbyuniversitetet

\begin{abstract}
The traditional Scandinavian voluntary sector model is under pressure. The aim of this chapter is to identify the importance of individuals' cultural background in creating new forms of community and belonging among young people of immigrant background.

Based on a qualitative study of eight national voluntary organizations for children and young people of immigrant background, we analyse transnational ties and practices in these organizations. What is the importance of these ties for social and political integration, and how do, these organizations meet the Goverment's requirement of being a traditional voluntary organization with a national scope?

This analysis shows that migrant organizations can be understood as both socio-cultural and political communities. With this dichotomy as a backdrop, we discuss how migrant organizations are trying to fill the role as intercultural communities and at the same time act as arenas for social and political integration.

We find that the socio-cultural and political dimensions of the migrant organizations cannot be understood independently of each other. This means that the integration process and transnational ties are two complementary processes. The chapter concludes that the migrant organizations have the potential to play an important role as arena for social and political integration. However, this potential seems to become activated because of the organizations transnational ties and networks, and not despite of them.
\end{abstract}

Key words: immigration, children, young people, migrant organizations, transnational ties

Sitering av denne artikkelen: Ødegård, G., \& Takle, M. (2018). Nye former for tilhørighet. Migrantorganisasjoner for barn og ungdom i en norsk sivilsamfunnskontekst. I B. Enjolras \& I. Eimhjellen (Red.), Fra kollektiv til konnektiv handling? Nye former for samfunnsengasjement og kollektiv handling i Norge (s. 271-298). Oslo: Cappelen Damm Akademisk. https://doi. org/10.23865/noasp.45.ch10 


\section{Innledning}

Den nordiske sivilsamfunnsmodellen utfordres fra flere hold. I dette kapitlet rettes fokus mot innvandring, og vi spør hvilken betydning individers tokulturelle bakgrunn har for hvilke nye former for fellesskap og tilhørighet som skapes. Basert på en kvalitativ studie av åtte nasjonale frivillige organisasjoner for barn og unge med innvandrerbakgrunn tar artikkelen utgangspunkt i de transnasjonale båndene og praksisene disse organisasjonene er bærere av. Hvilken betydning har de for sosial og politisk integrasjon, og hvordan utvikles migrantorganisasjonene $\mathrm{i}$ møte med den norske tradisjonen for frivillig organisering? Utgangspunktet for analysen er frivillige organisasjoners funksjoner som både sosiokulturelle og politiske fellesskap. Med denne tosidigheten som bakteppe diskuterer vi hvordan migrantorganisasjoner forsøker å fylle rollen som tokulturelle fellesskap og samtidig fungere som sosial og politisk integrasjonsarena.

Studien viser at migrantorganisasjonenes sosiokulturelle og politiske dimensjoner ikke kan forstås uavhengig av hverandre. I dette ligger det at integrasjonsprosessen og transnasjonale relasjoner er to komplementære prosesser. Migrantorganisasjoner har et potensial til å innta en viktig rolle som sosial og politisk integrasjonsarena i en norsk kontekst, men en slik posisjon synes i større grad å aktiviseres dersom organisasjonen har transnasjonale bånd og nettverk.

Innvandring til Norge har bidratt til fremveksten av et nytt flerkulturelt sivilsamfunn, noe som blant annet innebærer et $ø$ kt antall migrantorganisasjoner. Det er særlig to forhold som skiller migrantorganisasjoner fra andre typer frivillige organisasjoner i Norge. For det første rekrutteres medlemmer ut fra felles kultur eller landbakgrunn, og for det andre etableres organisasjonene med utgangspunkt i de transnasjonale bånd medlemmene er bærere av. Barn og ungdom som har innvandret til Norge, eller har foreldre som har innvandret, navigerer i et landskap der deres identitet formes i spennet mellom transnasjonal tilhørighet og integrasjon i en norsk kontekst. Det finnes lite forskning om hvilken betydning migrantorganisasjonenes transnasjonale nettverk og samarbeidspraksiser har for hvordan organisasjonenes drives i Norge (Hagelund \& Loga, 2009; Takle \& Ødegård, 2016). 
Temaet for dette kapitlet er hvilke nye former for tilhørighet som skapes i samspillet mellom transnasjonale bånd og integrasjon i migrantorganisasjoner for barn og unge. Vi reiser to spørsmål: Hvilken betydning har medlemmenes tokulturelle bakgrunn for hvordan organisasjonene driftes av lederne? Hvordan utvikles organisasjonene i møtet med den norske tradisjonen for frivillig organisering?

For å belyse disse spørsmålene bygger vi på Erdal og Oeppens (2013) analyser av hvordan transnasjonalisme og integrasjon er fremstilt og forstått i forskningslitteraturen. Står de i et motsetningsforhold til hverandre, eller opererer de i et samspill? Erdal og Oeppen skiller mellom en sosiokulturell og en strukturell/politisk dimensjon som både står i motsetning til hverandre og fungerer i et samspill. Mens Erdal og Oeppen konsentrerer seg om individers handlinger, vil vi analysere hvordan disse to dimensjonene virker, gjennom praksisene til åtte frivillige organisasjoner for barn og unge som enten har innvandret til Norge eller er barn av innvandrere. Vi undersøker hvordan nye former for frivillig organisering skapes i spennet mellom sosiokulturell tilhørighet til eget eller foreldres hjemland og politiske deltakelse i Norge.

$\AA$ studere dette gjennom flerkulturelle barne- og ungdomsorganisasjoner som er organisert innenfor rammene av en tradisjonell sivilsamfunnsmodell, gir mening fordi modellen blir tillagt samfunnsroller og funksjoner som sosial integrasjon, politisk styring og demokrati (Toqueville 1969, Rokkan 1987, Putnam 200o; Wollebæk \& Selle, 2002).

Studien bygger på kvalitative intervjuer med tillisvalgte ledere i disse organiasjonene. Dette er unge mennesker som står i, eller er på vei ut av, ungdomstida. De er organisasjonsetablerere innenfor tradisjonelle organisatoriske rammer, men også organisasjonsutfordrere ved å være blant de første som har bygd nasjonale interesseorganisasjoner for unge med felles flerkulturell bakgrunn. I tillegg til å være tradisjonelt organisert representerer organisasjonene en «ny» ungdomsgruppe og type fellesskap som ikke nødvendigvis identifiserer seg med foreldrenes nasjonale opprinnelse, men en ny form for hybrid identitet (Vathi, 2013). Når vi har valgt disse etablerte flerkulturelle barne- og ungdomsorganisasjonene som case, er det fordi vi mener de er godt egnet til å gi ny innsikt i hvordan nye former for sivilsamfunnsfellesskap oppstår i 
møte med tradisjonelle organiseringsformer. De åtte organisasjonene vi undersøker, omfatter hele utvalget av de organisasjonene for barn og unge med innvandrerbakgrunn som mottok nasjonalt driftstilskudd fra Barne-, likestilling og familiedepartementet i $2013 .{ }^{1}$ De fleste organisasjonene ble etablert etter 200o, og de er formelt organisert ved at de tilfredsstiller statlige krav til å motta driftstilskudd. Dette er en ordning som har til hensikt å styrke frivillige barne- og ungdomsorganisasjoner i Norge som demokratiske aktører i en nasjonal og internasjonal kontekst. $^{2}$

\section{Transnasjonale organisasjoner i norsk sivilsamfunnskontekst}

Etter at de pakistanske «fremmedarbeiderne» grunnla sine organisasjoner fra midten av 1960-tallet (Vassenden, 1997), ble det i de påfølgende årene etablert foreninger, nettverk og grupper basert på religiøs tilhørighet. Gjennom familiegjenforeninger utover på 1970-tallet økte behovet for sosiale møteplasser blant en voksende gruppe med felles nasjonal, etnisk eller kulturell identitet. Dette kulturelle og religiøse foreningslivet har økt både i omfang og mangfold etter som nye flyktninggrupper har kommet til Norge, der årsakene til migrasjon er mer komplekse enn tidligere (Melve, 2003; Predelli, 2006; Takle, 2014; Ødegård, Loga, Steen-Johnsen, \& Ravneberg, 2014). Dette har både ført til en mer sammensatt innvandrergruppe og et mer sammensatt foreningsliv (SSB 2017; NOU 2017:12). Det er begrenset kunnskap om dette organisasjonslandskapet (se Hagelund \& Loga, 2009; Ødegård, Loga, Steen-Johnsen, \& Ravneberg, 2014). For 15 år siden gjennomførte Mjelve (2003) en kartlegging som viste at det fantes om lag 1000 organisasjoner i hele Norge. Flertallet av disse var

1 Den eldste av disse organisasjonen ble etablert i 2000. Kriterier for tilskudd er basert på en interndemokratisk struktur, antall medlemmer under 26 år, utbredelse av lokallag samt revisorattestert regnskap for tilskuddsrapportering (se fordelingsutvalget.no).

2 Tilskuddsordningen har til hensikt å «... stimulere [organisasjonene] til engasjement og medansvar nasjonalt og/eller internasjonalt, og sikre organisasjonene som arena for medbestemmelse og demokrati» (Fordelingsutvalget.no). 
lokalt forankret uten noen nasjonal overbygning, hovedsakelig etablert for å ivareta og styrke etnisk og religiøs tilhørighet. Antallet per i dag er nok betydelig høyere (se Takle, 2014).

Tidligere forskning har imidlertid vist at frivillige organisasjoner for innvandrere og deres etterkommere fyller viktige funksjoner som sosiale, kulturelle og religiøse møteplasser, og at de definerer seg selv først og fremst som kulturelle - ikke politiske fellesskap (Lidén, 2001; Melve, 2003; Predelli, 2006; Rogstad, 2002). Det konkluderes med at organisasjonene både får og inntar en nokså begrenset rolle i norsk politisk offentlighet (Predelli, 2006; Rogstad, 2002). Denne forskningen har primært vært opptatt av å studere innvandrerorganisasjonenes kulturelle tiltak for egne medlemmer og den utadrettede rollen som korporativ interessebærere for etniske grupper i en lokal og nasjonal kontekst (for en oversikt se Hagelund \& Loga, 2009). Slik sett er forskningen forankret i en tradisjonell forståelse av den rollen sivilsamfunnsorganiseringen har hatt for fremveksten av det moderne demokratiet i Norge og Norden. Dette er i tråd med beskrivelsen av den særegne nordiske (skandinaviske) velferdsmodellen, der sivilsamfunnet og frivillig organisering løftes frem som en viktig bestanddel.

I boken Scandinavian Civil Society and Social Transformations. The Case of Norway oppsummerer Enjolras og Strømsnes (2018) de viktigste kjennetegnene ved denne modellen. Først og fremst rettes fokus mot de mange og bredt sammensatte demokratiske, frivillige organisasjonene som rekrutterer et høyt antall medlemmer og frivillige. Deltakelsen foregår ofte gjennom lokale foreninger, som er knyttet opp til en nasjonal overbygning, og deltakelsen bidrar til individenes sosiale og politiske integrasjon. Organisasjonene kjennetegnes videre av å rekruttere bredt fra ulike sosiale grupper, og den interndemokratiske strukturen gir medlemmene innflytelse i organisasjonen. Organisasjonen som interessebærer bidrar også til at de opererer som medierende institusjoner mellom individene og staten. Frivillige organisasjoners legitimitet hviler slik sett på en interndemokratisk forankring i en nasjonal kontekst. Dette til forskjell fra mange andre europeiske land, der legitimiteten hviler mer på et moralsk eller religiøst fundament (Lorentzen, 2004; Trägårdh \& Varmstad, 2009). 
Studier fra de nordiske landene viser at myndighetene har overført sentrale elementer ved denne måten å organisere frivillig sektor på til forventningene de stiller til innvandrerorganisasjoner (Togeby, 2004; Pyykkonen, 2007; Predelli, 2008; Hagelund \& Loga, 2009; Ødegård, 2010; Kugelberg, 2011; Bay, Hagelund, \& Finseraas, 2011), men bare noe få studier har vist eksplisitt til den nordiske tradisjonen for frivillig organisering (Takle, 2014; Takle \& Ødegård, 2016). I dette kapitlet vil vi bidra med analyser av hvilke nye former for tilhørighet som skapes i samspillet mellom transnasjonal tilhørighet og integrasjon i migrantorganisasjoners møte med den norske tradisjonen for frivillig organisering.

\section{Analytisk rammeverk}

Vårt analytiske rammeverk bygger på at integrasjon ikke er ensbetydende med å bli en del av det samfunnet som «er», men å være med på å forme det som «blir». Integrasjon forstått som en toveisprosess krever tilpasning og endring både fra minoritet og majoritet (Martiniello, 2005; Bauböck mfl., 2006; Yardakul, 2009). Det innebærer også at majoritetssamfunnets institusjoner må være åpne for å endre seg, slik at minoriteter er med på å bestemme både hvordan samfunnets institusjonelle rammeverk skal fungere, og hva den rådende oppfatning av det nasjonale fellesskapet skal være (Takle, 2014).

Transnasjonalisme viser til fenomener som finner sted innenfor avgrensede, sosialt organiserte forhold og geografiske steder i minst to nasjonalstater (Schiller, 2010; Faist, 2010). Det innebærer konkrete forbindelser til nasjonale og lokale steder, der hvert enkelt individ er plassert $\mathrm{i}$ en sosial sammenheng som knytter det til to eller flere steder samtidig. Et viktig kjennetegn ved transnasjonalisme er at de båndene og aktivitetene som knyttes på tvers av nasjonalstatens grenser, er regelmessige (Portes, Escobar \& Radford, 2007; Faist, 2010). Regelmessigheten skiller transnasjonalisme fra mer tilfeldige handlinger på tvers av grensene, som migranter alltid har tatt del i. Dermed fremstår transnasjonale aktiviteter og bånd som relativt stabile og vedvarende. Aktivitetene innebærer at man gjennomfører handlinger i to eller flere land, mens båndene betyr at man etablerer sosiale og kulturelle tilknytninger i flere nasjonalstatlige 
sammenhenger (Amelina \& Faist, 2008; 2012). Transnasjonalisme kan også defineres som grasrotaktivitet gjennomført i sivilsamfunnet. På den måten skiller den seg fra andre former for bånd og aktiviteter som krysser nasjonalstatens grenser (Portes, Escobar \& Radford, 2007). Grasrotaktiviteten er slik sett ikke det samme som den internasjonale aktiviteten som drives av regjeringer og andre nasjonalstatlige institusjoner, multinasjonale initiativ gjennom FNs organer, globale kirker og korporative enheter som opererer i flere land. Den viktigste forskjellen er ikke typen aktivitet, men hvor institusjonalisert aktørene er, og hvor mye makt de har.

Den tyske sosiologen Thomas Faist (2010) gir migrantorganisasjoner en sentral plass i sin forståelse av transnasjonalisme. Han legger vekt på at transnasjonale bånd er en del av nettverk og organisasjoner, og hvordan nettverk av organisasjoner går på tvers av nasjonalstatenes grenser. Likevel er det ikke slik at migrantorganisasjoners transnasjonale bånd, aktiviteter og nettverk nødvendigvis fører til at medlemmene reiser mellom land. Amelina og Faist (2008) viser videre at tyrkiske organisasjoner som organiserer aktiviteter i Tyskland, knytter sosiale og kulturelle bånd i flere nasjonalstatlige sammenhenger. Forskerne finner ingen motsetning mellom de tyrkiske organisasjonenes bånd til Tyrkia og deres arbeid for integrering i det tyske samfunnet (Amelina \& Faist, 2008). Tilsvarende funn finnes i en britisk kontekst, som viser at migranter som er involvert i transnasjonale aktiviteter, også er bedre integrert i det britiske samfunnet sosialt, økonomisk og politisk (Jayaweera \& Choudhury, 2008). Dette forklares med at sosial interaksjon og engasjement - lokal eller transnasjonalt - gir individer selvtillit til å involvere og engasjere seg i andre (Vertovec, 2009).

For å forstå hvilken betydning transnasjonal aktivitet har for integrasjon, er det avgjørende å anerkjenne at dette er komplekse prosesser der individers transnasjonale bånd og integrasjon utvikles på varierende måter, som er tett knyttet til de enkeltes livshistorier. Slike prosesser innebærer interaksjon og forhandlinger både mellom migranter og ikkemigranter, og mellom grupper og samfunn.

For å gripe denne kompleksiteten analytisk har vi som nevnt latt oss inspirere av Erdal og Oeppens (2013) gjennomgang av forskningslitteraturen. Forfatterne argumenterer for at integrasjon og transnasjonalisme har 
mange felles trekk, men der hovedforskjellene er det nasjonale og transnasjonale fokuset. Med dette som utgangspunkt har de utviklet en typologi med to dimensjoner - en sosiokulturell og en strukturell. Formålet er å illustrere hvordan samspillet mellom integrasjon og transnasjonalisme både kan adderes og utvikles gjennom gjensidig styrking (synergi), men også opptre som motsetninger for enkeltindivider. Med utgangspunkt i Erdal og Oeppens (2013) typologi har vi utviklet følgende analytiske rammeverk:

Den sosiokulturelle dimensjonen omfatter den rollen organisasjonene spiller og praksisen de utøver som arena for følelsesmessig og sosial tilhørighet i møtet mellom individer som deler en felles kulturell eller etnisk bakgrunn. Denne dimensjonen vil være utgangspunkt for å analysere hvordan medlemmenes tokulturelle bakgrunn kan være avgjørende for hvilke nye former for tilhørighet som skapes gjennom disse organisasjonene.

Den strukturelle/politiske dimensjonen omfatter i Erdal og Oeppens (2013) typologi både økonomiske, politiske og juridiske rettigheter og muligheter. I vår studie retter vi fokus utelukkende mot migrantorganisasjonenes betydning i en politisk sfære. Vi studerer dannelsen av institusjonelle nettverk, deres demokratiske verdigrunnlag, betydning av organisatoriske strukturer og hvordan organisasjonene utøver sin rolle som arena for politisk aktivisme, både i en nasjonal og transnasjonal kontekst. Med utgangspunkt i denne dimensjonen kan vi undersøke hvordan organisasjonene utvikles i møtet med den norske tradisjonen for frivillig organisering.

Typologien er egnet til å undersøke hvilken rolle migrantorganisasjoner har for ungdom som navigerer i et landskap der identitet formes i spennet mellom integrasjon i et majoritetssamfunn og transnasjonale føringer/ erfaringer/praksiser. Vi vil studere på hvilken måte vi finner igjen disse to hoveddimensjonene i organisasjonenes praksiser, enten som et samspill mellom dimensjonene eller om dimensjonene er isolert fra hverandre.

\section{Datagrunnlag og metode}

Undersøkelsen omfatter åtte migrantorganisasjoner for barn og for ungdom, som mottok støtte fra Fordelingsutvalget i 2013. Ingen av organisasjonene har religiøs formålsparagraf og fremstår som sekulære. Utvalget 
omfatter ikke fellesskap for ungdom forankret i moskeer eller andre trosog livssynssamfunn, noe som utelukker en viktig del av det flerkulturelle sivilsamfunnet i Norge. I oversikten nedenfor vises nøkkelinformasjon om organisasjonene, deres levetid, størrelse og statlig tilskuddsbeløp i 2013.

Oversikten viser at de fleste organisasjonene ble etablert etter år 200o, og at det var først i 2003 de mottok statstilskudd. Med unntak av Tamilsk kulturforening, og til en viss grad de vietnamesiske organisasjonene, er medlemstallet i organisasjonene lavt. For de minste organisasjonene ligger medlemstallet svært nær den nedre grensen for å motta statstilskudd, som er 100 medlemmer under 26 år. Flere av lederne i organisasjonene forteller at de aktiviserer mange flere enn medlemstallet tilsier, gjennom store arrangementer som kulturtreff og filmvisninger som trekker til seg deltakere på tvers av generasjoner. Selv om LNU krever at organisasjonene i prinsippet skal være åpne for alle, rekrutterer organisasjonene så å si utelukkende barn og unge med felles nasjonal eller kulturell bakgrunn. Dette er i tråd med hvordan tidligere studier viser at innvandrerorganisasjonene primært samler en kulturell eller etnisk gruppe (Rogstad, 2007). Disse organisasjonene har slik sett et begrenset rekrutteringsgrunnlag. Våre informanter beskriver det som en ufordring at mange av de potensielle medlemmene kommer fra familier med svake økonomiske ressuser. Dette gjør det vanskelig å inndrive medlemskontingenten, som må være på minium 50 kroner per år for å utløse statstilskudd. Ødegård har tidligere vist at medlemstallet i disse organisasjonene har holdt seg stort sett stabilt gjennom de 10 årene de har mottatt tilskudd (Eimhjellen \& Ødegård, 2016), noe som viser at driftstilskuddet ikke har bidratt til at organisasjonene har vokst. Samme studie viste også at flere migrantorganisasjoner har fått tilskudd gjennom støtteordningen i perioden frem til 2013, men noen har falt ut av ordningen fordi de ikke har klart å tilfredsstille de formelle tilskuddskravene til medlemsstørrelse og utbredelse av lokallag (Eimhjellen \& Ødegård, 2016 ibid.). Tilskuddskriteriene fra staten gir klare føringer for at samtlige barne- og ungdomsorganisasjoner skal ha et medlemsdemokrati med tillitsvalgte ledere på lokalt og nasjonalt nivå. Dermed er våre utvalgte case-organisasjoner organisert tilsvarende andre barne- og ungdomsorganisasjoner i Norge, der de arrangerer årsmøter både på lokalt og nasjonalt nivå, der de velger ledelse. 


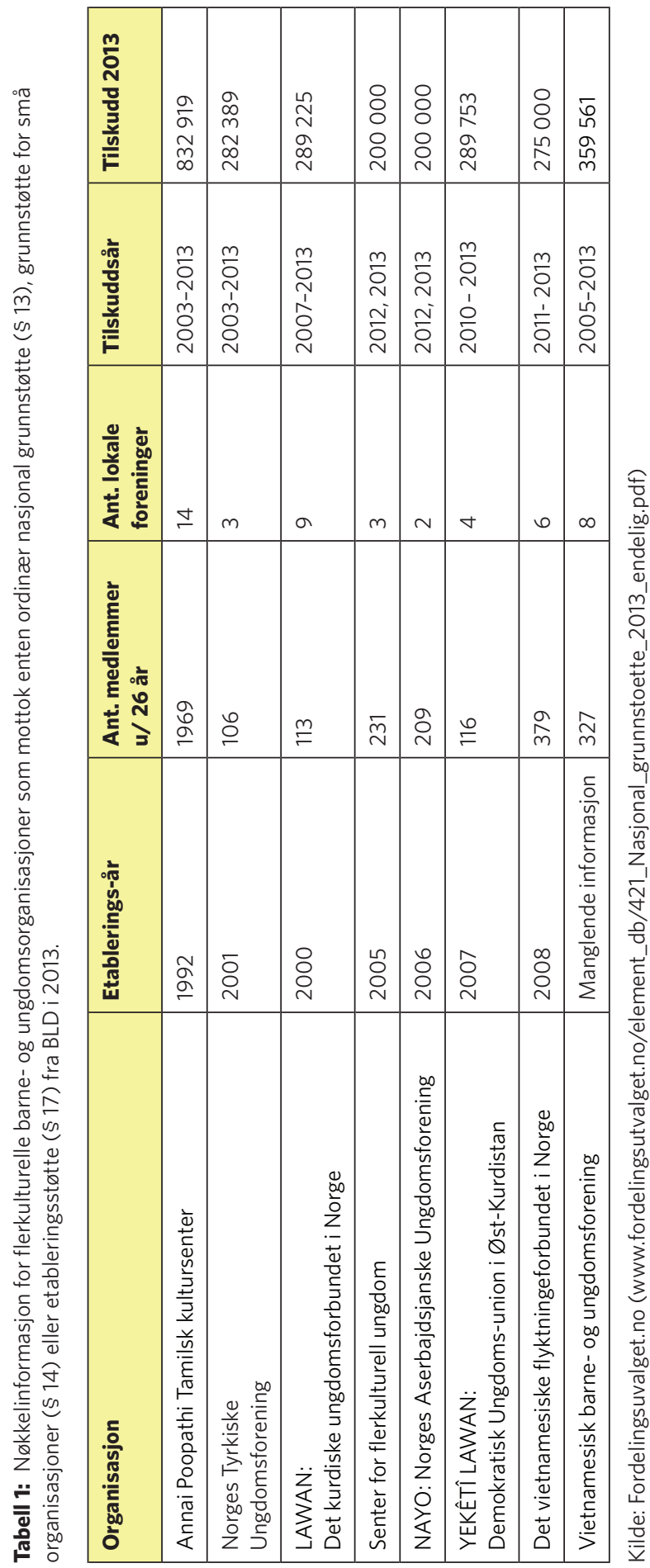


Datamaterialet utgjør intervjuer med tillitsvalgte ledere av disse åtte organisasjonene. Vi har også analysert tilgjengelige dokumenter som vedtekter, aktivitetsplaner, årsmeldinger og Facebook-profiler. Ved å sammenligne intervjumaterialet med dokumentanalysene har vi fått bekreftet at det er sammenheng mellom tillitsvalgtes individuelle fortellinger og organisasjonenes praksis. Fordi ingen av organisasjonene har ansatte og bemannede kontorer, kontaktet vi de tillitsvalgte lederne via SMS, e-post og gjennom personlige meldinger på Facebook. Tre av intervjuene ble gjennomført i kontorlokalene organisasjonene benytter til møter og andre aktiviteter sentralt i Oslo, mens tre andre ble gjennomført på forskernes arbeidsplass. Ett av intervjuene ble gjennomført på arbeidsplassen til en av lederne.

Det ble i alt gjennomført intervjuer med åtte personer i løpet av sommeren/høsten 2013 og våren 2014. I en av organisasjonene ville ikke ledelsen la seg intervjue, uten at vi kjenner årsaken til dette. Samtlige informanter hadde innvandrerbakgrunn, hvorav to var født og oppvokst i Norge, mens de fem andre kom til Norge som barn eller i tidlige tenår. Fem av informantene var menn, tre var kvinner. Alle var i aldersgruppen 20-30 år.

Intervjuene er semistrukturerte (Bernard, 2006). I dette ligger det at vi som forskere fulgte en intervjuguide, der spørsmålene var utarbeidet på forhånd innenfor spesifikke tema som ble ansett som relevante for studien. I tillegg ble det åpnet opp for nye tema underveis i intervjuet dersom informanten reiste relevante problemstillinger. En av forskerne ledet intervjuet og samtalen, mens den andre transkriberte. Intervjuene ble ikke tatt opp på bånd.

Organisasjonene som er med i studien er ikke anonymisert. Informasjon om hvilke organisasjoner som mottar nasjonalt grunnstøtte fra Fordelingsutvalget, er offentlig informasjon. Vi har likevel anonymisert informantene ved å ikke bruke navn. Vi har heller ikke oppgitt posisjonen informantene hadde i organisasjonenes ledelse på intervjutidspunktet. Årsaken er at intervjuene inneholder informantenes motiver og synspunkter på en rekke områder knyttet til integrasjon og politiske forhold i Norge og en hjemlandskontekst, noe som i enkelte miljøer skaper kontroverser. Informantene fikk informasjon om at full anonymitet 
ikke kunne sikres, da utvalgskriteriet fra Fordelingsutvalget er offentlig tilgjengelig. I de få tilfellene der informantene har gitt sensitive opplysninger, har vi utelatt dette i analysene, så sant det ikke har vært av spesiell interesse for forskningsarbeidet. Høsten 2015 fikk samtlige informanter, som er direkte sitert, tilbud om sitatsjekk. Når analysene i enkelte tilfeller har informasjon av nyere dato enn 2014, er dette primært basert på korrigeringer eller informasjon informantene har ment har vært viktig for å gi et oppdatert bilde. Utfordringen med å praktisere sitatsjekk er at relativt nyetablerte organisasjoner ofte gjennomgår store endringer på halvannet år, og informantene kan ønske å oppdatere og korrigere mye av informasjonen som er gitt på et tidligere tidspunkt. ${ }^{3} \mathrm{Vi}$ har i dette arbeidet ikke gått inn på personalmessige forhold eller organisasjonsinterne anliggender. ${ }^{4}$

\section{Migrantorganisasjoner i en norsk sivilsamfunnskontekst}

Migrantorganisasjonene i utvalget er organisert i tråd med den tradisjonelle nordiske sivilsamfunnsmodellen, der grunnlaget for statstilskudd hviler på en forståelse av at frivillige organisasjoner tjener som en sosial og politisk integrasjonsarena. Men hvilke former for fellesskap er det som dannes i møtet mellom migrantorganisasjonenes transnasjonale tilhørighet og den norske tradisjonen? I de empiriske analysene ser vi på migrantorganisasjonenes praksiser innenfor det vi har betegnet som en sosiokulturell dimensjon, og en mer politisk orientert dimensjon. Begge oppfattes som viktige betingelser for sosial og politisk integrasjon (Erdal \& Oeppen, 2013). Vi ser med andre ord nærmere på hvordan migrantorganisasjonene tilnærmer seg rollen som sosial integrasjonsarena når de i motsetning til tradisjonelle sivilsamfunnsorganisasjoner ikke rekrutterer

3 I ett tilfelle ble det uttrykt ønske om nytt intervju, for å oppdatere informasjonen om organisasjonen. Dette ble ikke imøtekommet, både på grunn av tidsbegrensninger og fordi studien er gjennomført på et visst tidspunkt for samtlige organisasjoner, og forteller om organisasjonenes posisjon relativt få år etter etableringen.

4 Prosjektet er meldt inn og anbefalt av Personvernombudet ved Norsk samfunnsvitenskapelig datatjeneste. 
fra det brede lag av folket, men blant en gruppe som har felles kulturell eller etnisk identitet. Deretter studerer vi hvordan de forvalter sin politiske rolle i en norsk kontekst, som bærere av transnasjonale relasjoner og tilhørighet.

\section{Hybrid identitet og integrasjonen - den sosiokulturelle dimensjonen}

Felles for organisasjonene som er med i studien, er at de unge medlemmene $\mathrm{i}$ all hovedsak har innvandrerbakgrunn og er bærere av en tokulturell identitet. Mens enkelte av organisasjonene representerer innvandrergrupper med lang botid i Norge, som vietnamesere og tamiler, har andre, som kurderne, kortere botid. Mens noen organisasjoner har medlemmer med foreldre som er født og vokst opp i Norge, har andre medlemmer som selv har innvandret til Norge. Uavhengig av botid betraktes «røttene», det stedet en selv eller forfedrene kommer fra, som viktig beveggrunn for organisasjonens etablering og drift:

Utenlandske ungdommer er røtterløse. De står et sted og så vet de ikke om de hører til det norske eller om de er en del av noen annet. Jeg følte at jeg hadde det sånn. Hvor er det jeg tilhører? Jeg hadde det problemet. Jeg ser at det er fint å ta med det beste av begge kulturer, både ha røtter og skaffe seg ressurser og integrere seg i det norske.

Dette sitatet fra en av organisasjonslederne, som selv kom til Norge som barn, viser kjernen i det budskapet flere av informantene ønsker å formidle: viktigheten av det sosiale fellesskapet med andre som er like en selv, og som har utfordringer med å finne tilhørighet som minoritet i et majoritetssamfunn. Vi skal la sitatet tjene som introduksjon for å se nærmere på organisasjonenes sosiokulturelle praksiser, og koblingen til integrasjon i det norske samfunnet.

Midt i Oslo sentrum ligger Vietnamhuset. Dette er en møteplass for norsk-vietnamesere bosatt i Østlandsområdet, og som kom til Norge som flyktninger i perioden 1975 til 1990, og deres etterkommere. Her har av en av de to vietnamesiske organisasjonene i materialet sin møteplass. Organisasjonen ble etablert i 2008 og har rundt 400 betalende medlemmer under 26 år. De fleste av disse er barn. Gjennom hele uken arrangeres en 
rekke kulturaktiviteter som dans, musikk, blomsterbinding, morsmålsundervisning og leksehjelp. Dette er aktiviteter primært for barn, men huset tjener også som møteplass for flere generasjoner av norsk-vietnamesere. Blant annet arrangeres det hvert år en årlig nasjonal barnefestival med 300-60o deltakere.

En viktig aktivitet for organisasjonen er morsmålsundervisningen. Når vi besøker Vietnamhuset en tidlig lørdag ettermiddag, er det mange frivillige i sving med å undervise 20-30 barn og noen tenåringer. Vår informant er tillitsvalgt i organisasjonens ledelse og har ansvaret for organisering av de frivillige lærerne. Disse gjør et viktig arbeid for å oppfylle organisasjonens målsetting: å gi barn som er født og oppvokst i Norge, kjennskap til forfedrenes kultur og språk. Båndene til Vietnam blir løsere når nye generasjoner vokser opp, sier hun, og organisasjonen skal være en arena der disse båndene kan bevares slik at man kan finne en balanse mellom det norske og det vietnamesiske. Vår informant forteller at det skjer en gradvis dreining: For hver ny generasjon som vokser opp, blir de «litt mer norske» enn den forrige. Vi skjønner hva hun mener, da vi overværer en pause i undervisningen. Fra å kommunisere på vietnamesisk går elevene over til å snakke norsk seg imellom. Og det er slik det er blitt, forteller vår informant. Norsk er det språket barna kan aller best, noe hun mener er naturlig når man i flere tilfeller må gå helt tilbake til besteforeldregenerasjonen for å finne dem som innvandret til Norge. For å illustrere sitt poeng ytterligere forteller hun om en gang lederne i organisasjonen viste en sketsj på vietnamesisk. Da sketsjen var ferdig, spurte barna om de ikke også kunne vise den på norsk slik at de kunne forstå den. Organisasjonsengasjementet for vår informant hviler på å gi unge norsk-vietnamesere den kulturballasten som språket representerer.

I likhet med den vietnamesiske organisasjonen har målsettingen for Tamilsk kulturforening vært «å formidle tamilsk språk og kultur» siden etableringen i 1992.5 Aktivitetsprofilen er lik, med både morsmålsundervisning, leksehjelp og kulturaktiviteter. Vår informant forteller at organisasjonen imøtekommer norske tamilers behov i ulike faser av livet: «Noen (medlemmer, forskers anm.) er borte noen år, men så kommer de tilbake

5 http://www.poopathi.no/web/nb/norsk_forside, lastet ned 30. april 2018. 
når de har fått barn». I dag har organisasjonen rundt 50-60 medlemmer som er «tredje generasjon», der foreldrene er født og vokst opp i Norge. De norskfødte foreldrene er en voksende gruppe i organisasjonen:

De (foreldrene, forskers anm.) kommer tilbake med barna sine fordi de ser behov for at barna har en identitet som er både norsk og tamilsk. Barna er mest i det norske miljøet, men i tillegg må de bruke tid på det tamilske.

Å bruke tid «på det tamilske» handler om å finne fotfeste som minoritet i en majoritetskultur, men også å opprettholde og bygge relasjoner med familie bosatt i forfedrenes hjemland eller i andre diasporaland. Det å lære språket og kjenne kulturen er en forutsetning for dette. I både den tamilske og den vietnamesiske organisasjonen satses det derfor mye på barnemedlemmene, da de er i en fase der de er mottakelige for denne typen impulser i større grad enn tenåringer.

Blant organisasjonene som ikke retter seg mot barnemedlemmer, men mer mot ungdom og unge voksne, er morsmålsundervisning, dans og sangtradisjon fra et «hjemland» mindre relevante aktiviteter. Det betyr ikke at det to- og flerkulturelle identitetsarbeidet er mindre viktig. For både i de kurdiske, den tyrkiske og den aserbajdsjanske organisasjonen er det de unge selv, ikke foreldrene, som sitter i styret og legger rammene for den organiserte aktiviteten. Det viktigste er å skape sosiale møteplasser for medlemmer og andre unge som deler en felles kulturell identitet. For å gjøre dette gjennomfører de hytteturer, faste idrettsaktiviteter (utenom den organiserte idretten), radiosendinger på morsmålet, kinovisninger med filmer fra «hjemlandet» og andre sosiale aktiviteter. I tillegg tilbyr de kurs i hvordan et lokallag skal driftes.

Til tross for at aktivitetene i barneorganisasjonene og ungdomsorganisasjonen er forskjellige, har de en felles målsetting om å styrke medlemmenes identitet, kultur og kjennskap til besteforeldres, foreldres eller egen migrasjonshistorie.

Den offentlige diskursen om identitet i Norge har i stor grad dreid seg om motsetninger mellom en norsk og en annen nasjonal identitet (Gullestad, 2006). I likhet med tidligere studier (se bl.a. Engebrigsten \& Fuglerud, 2007) beskriver ikke våre informanter det å ha to eller flere former for tilhørighet på en gang som noe som nødvendigvis er motsetningsfylt. 
Vi så innledningsvis i dette avsnittet hvordan en av informantene forteller at «utenlandske ungdommer er røtterløse». Her forteller han om hvorfor den kurdiske organisasjonen han selv er tillitsvalgt i, og andre migrantorganisasjoner for barn og ungdom er viktige:

Det å være medlem i en organisasjon som vår kan bidra til identitetsutviklingen til de unge. Vi vil at de skal være integrert i det norske samfunn, men samtidig bevare sin egen kultur. [...] Vår organisasjon kan bli en arena der man kan lære seg å være en del både av den norske og den kurdiske kulturen.

Intervjuer: Føler du organisasjonen kan tilby en dobbel tilhørighet?

Ja, vi prøver det. Vi merker det på de unge - de er jo som meg ... Poenget med organisasjonen er at de kan være både og. Dersom de ikke får mulighet til å utvikle begge kulturer, kan man komme i konflikt med seg selv. Man føler seg ikke så alene.

Informantene beskriver hvordan identitet har potensial til å bli problematisk for unge med innvandrerbakgrunn. Organisasjonen kan skape en trygg arena der de unge «kan være både og» - verken det ene eller det andre. En slik målsetting kommer også frem i flere av organisasjonenes vedtekter. For eksempel i Tamilsk kulturforening er det formulert i formålsparagrafen $(\$ 1)$ at målsettingen for organisasjonen er å «Veilede tamilske barn og ungdom til en meningsfylt integrering i det norske samfunnet». Også de kurdiske organisasjonene har vedtektsfestet at de skal bidra til å hjelpe sine medlemmer inn i det norske samfunnet, og hindre utenforskap og marginalisering ved å «kjempe mot vold, kriminalitet og gjengbevegelser blant kurdiske ungdommer» (jf. Lawans vedtekter).

De kulturelle praksisene som preger aktivitetstilbudet, må slik sett forstås innenfor en større ramme enn ren språk- og kulturopplæring. Det må knyttes opp mot en mobilisering rundt dannelsen av en felles identitet (Andersson \& Jacobsen et al., 2012).

Slik kan det argumenteres for at disse nye, formelle fellesskapene har tatt opp i seg en rolle som integrasjonsarena i et majoritetssamfunn. At organisasjonene egentlig driver integrasjonsarbeid, er informantene gjennomgående opptatt av å fortelle oss. De er nemlig godt kjent med at organisasjoner som deres i offentligheten ofte blir oppfattet som innadvendte 
og segregerende nettverk, og dermed som et potensielt hinder for integrasjon i det norske samfunnet. Temaet opptar dem, og de ønsker å gi en bredere forståelse av organisasjonenes rolle i å bygge fellesskap der ungdom med innvandrerbakgrunn ikke trenger å være enten norsk eller innvandrer, men både og, og noe annet enn sine foreldre - som en slags hybrid identitet som først blir motsetningsfylt dersom de unge ikke makter å finne seg til rette i spennet mellom transnasjonal tilhørighet og integrering. Dette er, ifølge dem vi snakket med, en viktig forutsetning for deltakelse i det norske samfunnet.

Et konkret eksempel på en slik forståelse finner vi i en av de kurdiske organisasjonene, som arrangerer «utdanningskurs». Ved å bruke unge kurdere som selv har tatt utdanning i Norge, vil man vise frem de gode og gjenkjennbare eksemplene. Foreldrene til de unge kurderne i Norge har tradisjonelt sett bare vært «bønder og enkle folk», som vår informant sier det, og har ikke kunnskapen som skal til for å veilede barna gjennom utdanningsløpet:

Jeg er annen generasjon innvandrer. Jeg har foreldre som ikke kan Norge. Jeg har savnet en veiviser, og idealer er vanskelig å finne. Vi har funnet hverandre.

De som har «funnet hverandre», er barn av innvandrere som har gjennomført lengre utdanningsløp. Gjennom utdanningskursene blir disse «veivisere» for andre unge ved å formidle kunnskap om de muligheter som finnes i det norske utdanningssystemet, fra valg av videregående skole til høyere utdanning ved høyskoler og universiteter. De unge kurderne ser utdanning som veien ut av en potensiell marginal posisjon, og en viktig beveggrunn for å arrangere utdanningskurs er å: «... få ungdommer vekk fra gata. Få dem sosialt sammen, få dem til å studere og til å integrere seg mer.» Det er derfor vår informant har valgt å satse på dette arbeidet:

Jeg kjenner meg igjen selv. Jeg var første generasjon ungdom av kurdere. Da jeg kom på universitetet, visste jeg ikke hva jeg skulle, jeg har gått gjennom mye, lært meg mye. Jeg fant mange ungdommer av samme type, og jeg kan hjelpe noen med de samme problemene som jeg selv hadde.

Han var en av de første, og han var med på å etablere organisasjonen han nå leder. Det er flere av informantene som er som han, som forteller 
oss om det å være pionerer, å gå foran og bane vei for andre som kommer etter dem, og som har etablert organisasjonen med dette siktemålet. Eksempelet er illustrerende for hvordan de kulturelle praksiser som preger aktivitetstilbudet, må forstås innenfor en større ramme knyttet opp mot en mobilisering og solidaritet rundt en felles identitet (se også Andersson, Jacobsen, Rogstad \& Vestel, 2012).

\section{Demokrati, kulturkamp og transnasjonale nettverk - den politiske dimensjonen}

Migrantorganisasjonene i denne studien har valgt å organisere seg som tradisjonelle demokratiske, medlemsbaserte organisasjoner. En åpenbar grunn er økonomi, ettersom norske myndigheter legger denne typen kriterier til grunn for tildeling av statsstøtte. Dette innebærer at utvalget av organisasjoner i denne studien har tilpasset seg den norske tradisjonen for frivillig organisering. Spørsmålet vårt dreier seg dermed om hvordan migrantorganisasjonene, som i likhet med andre frivillige barne- og ungdomsorganisasjoner i Norge både er demokratiske og medlemsbaserte, utvikler i seg i dette møtet.

Flere av informantene legger vekt på betydningen av å være en selvstendig frivillig organisasjon med en intern demokratisk struktur. Dette sikrer dem et autonomt fellesskap, med myndighet til selv å bestemme, noe som flere synes er viktig ut fra sin migrasjonshistorie, som ofte handler om å bli undertrykt og forfulgt. En som målbærer dette perspektivet, er en informant som kom til Norge to år før vi intervjuet ham. Han var tillitsvalgt i en av de kurdiske organisasjonene, og hadde vært aktivt medlem i moderorganisasjonen, som er lokalisert i hjemlandet. Båndene til hjemlandet var fortsatt sterke, likeså drømmen om et fritt Kurdistan. Informanten var klar på at demokrati og frihet må læres. Kunnskapen han får gjennom deltakelse i den norske avdelingen av organisasjonen, må videreformidles til dem «hjemme».

Vi har et mål om å lære oss om demokrati og frihet. Kanskje vi kan ha det sånn

en dag i vårt eget land. Et annet mål er å opplyse medlemmene om det kurdis-

ke problemet, om hvorfor vi er her i Norge. Vi har problemer der nede, vi må 
opplyse ungdommene i Europa om dette. Gjennom denne organisasjonen vil vi opplyse andre om det kurdiske problemet. Vi må prøve å lære oss mer om menneskerettigheter, prøver å lære oss mer om Europa (resonnementet tar han på kurdisk, og det oversettes av en medinformant).

Demokrati og frihet er målet for de kurderne vi snakket med. Norske organisasjoner som denne kan sette det kurdiske problemet på dagsorden i Europa. At organisasjonen er demokratisk bygd opp, kan gi inspirasjon til unge i Kurdistan til å læres opp i demokratiske prinsipper og menneskerettigheter. Informanten har en plan om en gang å reise hjem. Arbeidet i den norske organisasjonen er viktig for dette målet: «Jeg håper en dag vi kommer tilbake til et demokratisk land. Det vi gjør her, er for det målet», sier han.

Også i en annen kurdisk organisasjon ligger den politiske kampen foreldregenerasjonen har ført som et bakteppe for organisasjonens etablering og aktiviteter, og det fortelles om støttende foreldre for den innsatsen som legges ned i organisasjonen.

Pappa har lang erfaring i organisasjonsarbeid og politikk og har hele tiden vært til hjelp for meg og mine søsken [...] De fleste foreldre som har kommet til landet, har vært aktive i hjemlandet og vil at barna skal være aktive i Norge, at de skal bevare sin kultur, vise fram den kurdiske kulturen til Norge. Det blir en del av livet.

En annen informant uttrykker det slik:

Jeg har blitt backet opp hjemmefra. Det er viktig, for man bruker så mye tid på det (organisasjonsarbeid, forskers anm.). Uten backing ville det vært vanskelig. [...] Vår foreldregenerasjon har kommet hit uten noen ting. Men pappa har motivert meg til gjøre dette, uten nytte-gevinsten. Uten aksept hjemmefra ville jeg ikke vært her.

Sitatene viser hvordan etableringen av migrantorganisasjoner forvalter et politisk engasjement, som er målbåret av en foreldregenerasjon som ser verdien av sivilsamfunnet som arena for politisk. Eksemplene tydeliggjør et felt som i liten grad er studert, nemlig hvilken betydning kontekstuelle forhold i landet man har reist fra, har for det engasjementet som kommer til syne det stedet man bor. Det finnes lite forskning på temaet i en 
norsk kontekst, men Kim og Amnå (2015) har vist at unge svensker med kurdisk bakgrunn har et større samfunnsengasjement enn ungdommer med etnisk svensk og irakisk bakgrunn. Forskerne mener at hjemlandskonteksten og foreldrenes normer for sivilt/politisk engasjement påvirker barnas politiske kompetanse og engasjement i Sverige. Det skjer med andre ord en generasjonsoverføring av politisk engasjement, som på sett og vis importeres gjennom migrasjon.

Et annet eksempel på denne type «import» av politisk engasjement finner vi i Tamilsk kultursenter. Til tross for at vår informant er tydelig på at organisasjonen er politisk og religiøst uavhengig, blir den av singalesiske myndigheter stemplet som en terrororganisasjon. Stempelet gjør det vanskelig for organisasjonen å rekruttere tillitsvalgte både på lokalt, regionalt og nasjonalt nivå da samtlige tillitsvalgte i frivillige organisasjoner skal registreres i Brønnøysundregisteret. Registeret ligger åpent tilgjengelig, og i deler av det tamilske miljøet har det oppstått en frykt for å ha navnet sitt registrert. «Det er derfor vi ikke legger mye informasjon på nettet. Det er forbundet med risiko. Det er overvåkning også i Norge», forteller vår informant. "Siden 2009 har (den singalesiske, forskers anm.) regjeringen hatt som mål å ødelegge tamilsk organisering. Den vil ikke at tamilene skal være tamiler», som han sier det. For Tamilsk kulturforening innrammes kulturformidling og morsmålsundervisning i fortellingen om kampen om frihet og demokrati for en forfulgt folkegruppe. Eksemplene illustrerer det faktum at kultur og politikk er sammenvevde dimensjoner.

Et annet eksempel illustrerer hvordan etableringen av ungdomsstyrte fellesskap blir oppfattet som kontroversielt i enkelte innvandrermiljøer. I en av organisasjonene måtte de unge kjempe for at organisasjonen i det hele tatt skulle bli stiftet, da krefter i deler av migrantmiljøet, blant foreldregenerasjonen, motarbeidet etableringen av en slik selvstendig, demokratisk, politisk og religiøst nøytral ungdomsorganisasjon med egne vedtekter. At organisasjonen insisterte på å være utenfor de voksnes innflytelse og kontroll, ble sett på som en mulig trussel både mot foreldrekontroll og bevaring av kulturelle praksiser.

Da vi etablerte organisasjonen, satt jeg i mange møter med menn. Jeg brukte mye tid til å forklare hvorfor det var viktig å ha en organisasjon for ungdom hvor alle var velkommen, uavhengig av politisk og religiøs tilhørighet. Folk 
visste ikke hva dette var. De fulgte med - det var bare møter, møter den første tiden.

Dialogarbeidet blant annet med etablerte voksenorganisasjoner tok mye tid, men var helt avgjørende for opprettelsen og driften av organisasjonen, forteller vår informant. Alternativet ville vært en vedvarende skepsis og manglende tillit der foreldre ville vegret seg for å sende barna til aktiviteter i regi av organisasjonen. Motstanden var særlig knyttet til ungdomsorganisasjonens partipolitiske og religiøst nøytrale linje, samt målsettingen om å være en selvstendig og inkluderende arena der: «... ungdom selv skal kunne organisere seg, og selv ordlegge seg om hva som er vanskelig», som hun sier det. Ingen skulle stenges ute. Dialogarbeidet lyktes og ga organisasjonen et bredt aktivitetstilbud til grupper av unge som, ifølge vår informant, ellers ikke ville hatt organiserte fritidsaktiviteter blant annet på grunn av svake økonomiske ressurser i familiene.

Med et institusjonelt perspektiv som sivilsamfunnsperspektivet representerer, kan man lett stå i fare for å tolke innvandrerorganisasjonenes politiske relevans som begrenset fordi de i liten grad synes å fungere som pressgruppe i en nasjonal offentlighet (Koopmans, 2004). Denne beskrivelsen oppsummerer på en god måte også våre migrantorganisasjoners politiske praksiser. Generelt finner vi i svært liten grad at organisasjonene driver politisk påvirkningsarbeid overfor norske myndigheter. Myndighetskontakten begrenser seg i all hovedsak til den kontakten som er nødvendig for å søke om og motta statstilskudd. Utover dette er det lite institusjonell nettverksbygging, både på lokalt og nasjonalt nivå. Unntaket er paraplyorganisasjoner som Landsrådet for Norges barne- og ungdomsorganisasjoner (LNU), som alle organisasjoner i denne studien er medlemmer i. LNU er også en arena der tillitsvalgte og medlemmer deltar på diverse kurs og lederseminar, samt får hjelp og veiledning ved behov. En av informantene har selv hatt tillitsverv i LNU, og de fleste av organisasjonene har deltatt på det årlige representantskapsmøtet til LNU.

Den viktigste grunnen til de svake institusjonelle nettverkene er ifølge våre informanter mangel på menneskelige ressurser til å prioritere tid til slik aktivitet. Ingen av organisasjonene har egne ansatte som dermed kan delta på relevante møter på dagtid. De tillitsvalgte er enten elever, studenter eller i lønnet arbeid, og må derfor begrense sin deltakelse til de 
absolutt mest nødvendige møtene. Våre yrkesaktive informanter forteller at både de selv og andre i ledelsen tar ut feriedager for å delta på viktige møter og samlinger på dagtid. Manglende økonomiske ressurser til ansatte eller frikjøp av tillitsvalgte beskrives som et strukturelt hinder for å bygge denne typen institusjonelle bånd.

Når vi spør om organisasjonenes kontakt med søsterorganisasjoner i andre vestlige land, eller i landet de har reist fra, trer et annet bilde frem. De forteller om samarbeid med tilsvarende organisasjoner i andre nordiske land, men påpeker samtidig at de norske organisasjonene er små, med få medlemmer sammenlignet med land med en større innvandrerbefolkning, som Sverige og Tyskland. De har dermed ikke kapasitet til mye aktivitet. Likevel finner vi eksempler på at transnasjonale relasjoner og nettverk er viktig, både ved at de får tilgang til blant annet undervisningsopplegg for språkopplæring, ved at de bidrar i arbeidet med å styrke moderorganisasjonen $i$ «hjemlandet», og mer generelt deltar i det transnasjonale rettighetsarbeidet for undertrykte grupper.

For eksempel inngår en av de kurdiske organisasjonene i et større transnasjonalt nettverk av tilsvarende kurdiske organisasjoner fra ulike land. Moderorganisasjonen er lokalisert i Irak, og det arrangeres årlige kongresser der delegater fra søsterorganisasjoner fra en rekke land deltar. Her har også representanter fra den norske organisasjonen deltatt og «hatt stemmerett». Det er viktig, forteller vår informant, å styrke moderorganisasjonen. Selv om den norske organisasjonen har sitt primære fokus på å skape fellesskap for unge kurdere i Norge, har det vært arrangert dugnader for å samle inn penger til moderorganisasjonen i Kurdistan:

Vi sendte penger en gang. Da gjennomførte vi dugnader. Pengene gikk til å pusse opp lokalene deres, kjøpe PC og sånn. I fjor sommer var jeg på kontoret deres [...] i Irak. De hadde fått nytte for pengene vi sendte. Det så jeg.

Tilsvarende transnasjonal nettverksbygging finner vi i Tamilsk kulturforening. Kulturforeningen deltar i europeiske utvekslingsprogrammer for tamilske barn: «Vi ønsker å få utveksling med barn for eksempel i Paris eller i Tyskland. Det vil styrke barnas identitet og å lære andre språk. De kan lære både tamilsk og fransk.» Det tamilske, transnasjonale nettverket av vestlige, nasjonale organisasjoner utvikler blant annet 
undervisningsmateriell for morsmålsopplæring. Dette benytter den norske organisasjonen seg av.

\section{Konklusjon: Transnasjonale bånd som potensial for integrasjon}

I dette kapitlet har vi undersøkt hvilke nye former for tilhørighet som skapes i samspillet mellom transnasjonal tilhørighet og integrasjon i migrantorganisasjoner for barn og unge. Vi har reist spørsmål om hvilken betydning medlemmenes tokulturelle bakgrunn har for hvordan organisasjonene driftes av lederne, og hvordan organisasjonene utvikles $\mathrm{i}$ møtet med den norske tradisjonen for frivillig organisering.

Analysen viser to endringsprosesser som foregår samtidig, og som er tett infiltrert. Den ene handler om den tokulturelle tilhørigheten som mange minoritetsungdommer utvikler. Her gis det beskrivelser om hvordan globale og nasjonale impulser blandes, og som over tid skaper nye former for hybrid og transnasjonal tilhørighet. Den andre er hvordan enkeltindivider med innvandrerbakgrunn søker kollektive løsninger gjennom formelle organisasjoner, og hvordan disse organisasjonene utvikles i møtet med den etablerte formen for frivillig organisering. Disse to endringsprosessene foregår som et samspill mellom transnasjonalisme og integrasjon.

Våre intervjuer viser hvordan migrantorganisasjoner for barn og ungdom forsøker å fylle rollen som tokulturelle fellesskap, og samtidig fungere som integrasjonsarena i en norsk kontekst og innenfor rammene av den norske tradisjonen for frivillig organisering. Barneorganisasjonene fungerer som et sted der barna lærer om sine foreldres og/eller besteforeldres kulturelle bakgrunn. Barna beskrives som mer norske enn sine foreldre, og får primært språk- og kulturopplæring fra foreldrenes «hjemlandskultur». Hensikten med denne aktiviteten er å skape et fotfeste i en dobbel tilhørighet. Mens barneorganisasjonene er styrt av foreldre, blir ungdomsorganisasjonene drevet av unge mennesker som søker sammen med andre som har tilsvarende tokulturelle bakgrunn. De ønsker å dele erfaringer og hjelpe hverandre med potensielle problemer og utfordringer i møte med det norske samfunnet, der deres foreldre ikke har kompetanse 
til å veilede. Medlemmenes tokulturelle bakgrunn er avgjørende for de nye formene for hybrid og transnasjonal tilhørighet som formes gjennom organisasjonene, der det å styrke medlemmenes identitetsarbeid handler om noe mer enn to- eller flerkulturell i et majoritetssamfunn, og noe annet enn den identiteten som forvaltes av foreldregenerasjonen. Slik sett beskrives organisasjonenes rolle langt på vei som en arena der et transnasjonalt identitetsarbeid fremstår som en forutsetning for vellykket integrasjon og deltakelse i majoritetssamfunnet.

Fordi vårt utvalg bare omfatter de migrantorganisasjonene som mottar nasjonalt driftstilskudd, har de en intern demokratisk struktur. Disse institusjonelle rammene beskrives ikke som en nødvendig tilpasning, men som en grunnleggende og viktig dimensjon ved organisasjonen. De ønsker både å være selvstyrende fellesskap og demokratiske aktører. Organisasjonene fremstår imidlertid som passive politiske og interessebærende aktører i en norsk offentlighet. Deres institusjonelle nettverk i Norge begrenser seg til deltakelse i store organisasjonsparaplyer, og særlig LNU. Det er begrenset hvor mye ressurser organisasjonene har kapasitet til å legge i institusjonell nettverksbygging. Samtidig ser vi flere eksempler på transnasjonal nettverks- og relasjonsbygging gjennom utveksling av kursmateriell med søsterorganisasjoner i andre diasporaland, innsamling av penger til drift av moderorganisasjonen i et «hjemland» og deltakelse på konferanser med søsterorganisasjoner fra andre land. Møtet med migrantorganisasjonenes politiske engasjement strekker seg slik sett utover en tradisjonell forståelse av frivillige organisasjoners rolle som politisk integrasjonsarena. Selv om den politiske dimensjonen kommer tydeligst frem i ungdomsorganisasjonenes praksiser, ligger den som et bakteppe for de sosiokulturelt orienterte aktivitetene i barneorganisasjonene. Overordnet viser studien at disse migrantorganisasjonenes politiske potensial ikke utelukkende kan forstås ut fra en nasjonal kontekst, fordi de primært aktiveres på en transnasjonal arena og i transnasjonale relasjoner.

Gjennomgående finner vi støtte for at det foregår et samspill mellom transnasjonale bånd og integrasjon. Dette reflekteres i hvordan organisasjonenes sosiokulturelle og politiske praksiser er tett sammenvevd. Vi finner at disse migrantorganisasjonene har potensial til å innta en viktig 
rolle som sosial og politisk integrasjonsarena i en norsk kontekst, men en slik posisjon synes i større grad å aktiviseres dersom organisasjonene har transnasjonale bånd og nettverk. Integrasjon utelukker med andre ord ikke utvikling av transnasjonale relasjoner og vice versa. Snarere tvert imot. De organisasjonene som har transnasjonale bånd og utøver transnasjonale praksiser, synes å være de som i størst grad orienterer seg mot norsk nettverksbygging. Det er også de som i størst grad fremhever viktigheten av å være integrasjonsarena for sine medlemmer inn i en norsk kontekst.

\section{Referanser}

Andersson, M., et al. (2012). Kritiske hendelser - Nye stemmer. Oslo: Universitetsforlaget.

Amelina, A., \& T. Faist (2008). Turkish Migrant Associations in Germany: Between Integration Pressure and Transnational Linkages'. Revue européenne des migrations internationales 24(2): 91-120.

Amelina, A., \& T. Faist (2012). De-naturalization the national in research methodologies: Key concepts of transnational studies in migration. Ethnic and Racial Studies 35(10): 1707-1724.

Bauböck, R., A. Kraler, M. Mariniello, \& B. Perchinig (2006). Migrants' Citizenship: Legal Status, Rights and Political Participation. I R. Penninx, M. Berger \& K. Kraal (Red.), The Dynamics of International Migration and Settlement in Europe (s. 65-99). Amsterdam: Amsterdam University Press.

Bay, A.H., A. Hagelund, \& H. Finseraas (2010). Civil Society and Political Integration of Immigrants in Norway. I B. Bengtsson, P. Strömblad \& A.H. Bay (Red.). Diversity, Inclusion and Citizenship in Scandinavia (s. 295-323). Newcastle upon Tyne: Cambridge Scholars Publishing.

Bernard, H. R. (2006). Reserach Methods in Anthropology. Qualitative and Quantitative Approcahes. Lanham: Altamira Press.

Eimhjellen, I. (2016). Innvandrarar si deltaking i norsk frivilligliv - nye tal og metodiske utfordringar. Oslo: Senter for forskning på sivilsamfunn og frivillig sektor.

Eimhjellen, I., \& Ødegård, G. (2016). Klima og migrasjon. To casestudiar av sivilsamfunnsorganisering i ei ny tid. Oslo: Senter for forskning på sivilsamfunn og frivillig sektor.

Engebrigsten, A., \& Ø. Fuglerud (2007). Ekteskap, slektskap og vennskap. Nettverksanalyse som inntak til kulturelle prosesser. I O. Fuglerud \& T. H. 
Eriksen. Grenser for kultur? Perspektiver fra norsk minoritetsforskning. Oslo: Pax.

Enjolras, B., \& Strømsnes, K. (2018). The Transformation of the Scandinavian Voluntary Sector. I B. Enjolras \& K. Strømsnes (Red.), Scandinavian Civil Society and Social Transformations. The Case of Norway (s. 1-24). Switzerland: Springer.

Erdal, M. B., \& Oeppen, C. (2013). Migrant Balancing Acts: Understanding the Interactions Between Integration and Transnationalism. Journal of Ethnic and Migration Studies, 39(6), 867-884.

Faist, T. (2010). Diaspora and Transnationalism: What kind of dance partners? I R. Bauböck and T. Faist (Red.), Diaspora and Transnationalism. Concepts, Theories and Methods. Amsterdam: Amsterdam University Press.

Friberg, J. H., \& Midtbøen, A. H. (2017). Innvandrernes etterkommere: Teoretiske og komparative perspektiver. Norsk sosiologisk tidsskrift. Årg. 1, Nr. 1, s. 5-14.

Gullestad, M. (2006). Plausible Prejudice. Everyday experiences and social images of nation, culture and race. Oslo, Universitetsforlaget.

Hagelund, A, \& J. Loga (2009). Frivillighet, innvandring, integrasjon. Oslo: Senter for forskning på sivilsamfunn og frivillig sektor.

Jayaweera, H, \& T. Choudhury (2008). Immigration, Faith and Cohesion: Evidence from Local Areas with Significant Muslim Populations. York: Joseph Rowntree Foundation.

Kim, Y. \& E. Amnå (2015). Civic engagement among minority immigrant youth groups in Sweden: Civic engagement among migrant youths in Sweden: Do parental norms or immigration generation matter? In: M. Barrett \& B. Zani (Ed.), Political and Civic Engagement: Multidisciplinary Perspectives (pp. 248-267). London: Routledge.

Koopmans, R. (2004). Migrant mobilisation and political opportunities: variation among German cities and a comparison with the United Kingdom and the Netherlands. Journal of Ethnic and Migration Studies 30(3): 449-470.

Kugelberg, C. (2011). Integration Policy and Ethnic Minority Associations. I C. Shore, S. Wright \& D. Pero (Red.), Policy Worlds. Anthropology and Analysis of Contemporary Power (s. 264-282). New York: Berhahn Books.

Lidén, H. (2001). Innvandrerorganisasjoner - integrering eller marginalisering? I L. S. Henriksen \& B. Ibsen (Red.), Frivillighedens udfordringer - nordisk forskning om frivilligt arbejde og frivillige organisationer. Odense: Odense Universitetsforlag.

Lorentzen, H. (2004). Fellesskapets fundament: sivilsamfunnet og individualismen. Oslo: Pax.

Martiniello, M. (2005). Political Participation, Mobilisation, and Representation of Immigrants and their Offspring in Europe. Willy Brandt Series of Working Papers in International Migration and Ethnic Relations 1/05. Malmø University. 
Melve, J. (Red.) (2003). Innvandrerorganisasjoner i Norge. Innvandrerorganisasjoner i Norden. København, Nordiska Ministerråd.

NOU 2017:12 (2017). Integrsjon og tillit. Langsiktige konsekvenser av høy innvandring. Oslo: Justis- og beredskapsdepartementet.

Predelli, L. N. (2006). Innvandrerorganisasjoner i Norge: Utforming, aktiviteter og politisk deltakelse. Oslo: NIBR.

Predelli, L. N. (2008). Political and Cultural Ethnic Mobilisation: The Role of Immigrant Associations in Norway. Journal of Ethnic and Migration Studies, 34(6): 935-954.

Putnam, R. D. (200o). Bowling Alone: The Collapse and Revival of American Community. New York: Simon \& Schuster.

Pyykkonen, M. (2007). Integrating Governmentality: Administrative Expectations for Immigrant Associations in Finland. Alternatives, 32(1): 197-224.

Rogstad, J. (2002). Minoritetseliten og majoritetsarenaer. I G. Brochmann, T. Borchgrevink, \& J. Rogstad (Red.), Sand i maskineriet. Oslo: Gyldendal Norsk Forlag.

Rogstad, J. (2007). Demokratisk fellesskap. Politisk inkludering og etnisk mobilisering. Oslo: Universitetsforlaget.

Rokkan, S. (1987). Stat, nasjon, klasse. Oslo: Universitetsforlaget. Oslo: Universitetsforlaget.

Schiller, N. G. (2010). Long Distance Nationalism and Peripatetic Patriots. I ss. 27-53 B. Riccio \& C. Brambilla (Red.), Transnational Migration, Cosmopolitanism and Dis-located Borders (s. 27-53). Luglio: Guaraldi

SSB 2017. Nøkkeltall for innvandring og innvandrere. https://www.ssb.no/ innvandring-og-innvandrere/nokkeltall. Lastet ned 30. august 2017.

Takle, M. (2014). Politisk integrering. Innvandrerorganisasjoner som skoler i demokrati og byråkrati. Oslo: Cappelen Damm Akademisk.

Takle, M. (2018) Cultural Recognition and Democratic Participation - Immigrant Organisations in Oslo. I J.E. Fossum, R. Kastoryano \& B. Siim (Red.), Diversity and Contestations over Nationalism in Europe and Canada (s. 365-394). London: Palgrave Macmillan.

Takle, M., \& G. Ødegård (2016). When Policy Meets Practice: A study of Ethnic Community-Based Organisations for Children and Youth. I M.L. Seeberg \& E. Goździak (Red.), Contested Childhoods - Growing up in Migrancy. Frankfurt am Main: Springer Verlag.

Togeby, L. (2004). It depends ... How organisational participation affects political participation and social trust among second-generation immigrants in Denmark, Journal of Ethnic and Migration Studies, 30(3): 509-528.

Trähgårdh, L., \& J. Vamstad (2009). Att ge eller att beskattas. Avdragsrätt för gåvor till ideell verksamhet $i$ Sverige och andra länder. Stockholm: Tankesmedjan för det civila samhället. 
Vassenden, K. (1997). Innvandrere i Norge. Hvem er de, hva gjør de og hvordan lever de? Oslo: Statistisk sentralbyrå.

Vathi, Z. (2013). Transnational orientation, cosmopolitanism and integration among Albanian-origin teenagers in Tuscany. Journal of Ethnic and Migration Studies 39(903-19).

Vertovec, S. (2009). Transnationalism. Abingdon: Routledge.

Yurdakul G. (2009). From Guest Workers into Muslims: The Transformation of Turkish Immigrant Associations in Germany. Newcastle: Cambridge Scholars Press.

Portes, A., C. Escobar \& A.W. Radford (2007). Immigrant Transnational Organizations and Development: A Comparative Study. International Migration Review 41(1): 242-281.

Ødegård, G. (2010). Foreningsliv i et flerkulturelt lokalsamfunn. En studie om integrasjon og sosial kapital, ISF Rapport 6, Oslo.

Ødegård, G., et al. (2014). Fellesskap og forskjellighet. Integrasjon og nettverksbygging $i$ flerkulturelle lokalsamfunn. Oslo: Abstrakt Forlag. 


\section{Biografier}

Bernard Enjolras (ph.d sosiologi; ph.d Samfunnsøkonomi) er forsker I ved Institutt for samfunnsforskning og Leder av Sentret for forskning på sivilsamfunn og frivillig sektor. Hans forskningsinteresser inkluderer temaer som sivilsamfunn og tredje sektor, offentlig politikk, samfunnsengasjement, digitalisering og sosiale medier, ytringsfrihet, tillit og terror. Han har blant annet vært medforfatter for bøkene Liker-Liker Ikke (Cappelen Damm Akademisk, 2013), The Third Sector as a Renewable Resource for Europe (Palgrave MacMillan, 2018) og medredaktør for Scandinavian Civil Society and Social Transformations (Springer, 2018).

Ivar Eimhjellen (ph.d Sosiologi) er forsker II ved NORCE Samfunn og Senter for forskning på sivilsamfunn og frivillig sektor. Eimhjellen har jobbet med ulike temaer knyttet til sivilsamfunn og samfunnsdeltakelse med særlig vekt på sosiale medier og digitalisering, innvandring og integrering, samskaping og sosialt entreprenørskap. Det siste året har han blant annet bidratt med kapitler i bøkene Scandinavian Civil Society and Social Transformations (Springer, 2018) og Civic Engagement in Scandinavia (Springer, 2019).

Audun Beyer er utdannet medieviter og forsker ved Institutt for samfunnsforskning. I sin forskning har han vært opptatt av politisk kommunikasjon, nyheter, opinionsdanning og mediepåvirkning, stort sett basert på kvantitative data. Hans forskning er publisert i flere internasjonale tidsskrifter, og har mottatt priser på konferanser i regi av International Communication Association (ICA) og Association for Education in Journalism and Mass Communication (AEJMC).

Audun Fladmoe (ph.d. statsvitenskap) er forsker II ved Institutt for samfunnsforskning og Senter for forskning på sivilsamfunn og frivillig sektor. 
Hans forskningsinteresser inkluderer temaer som frivillig innsats og andre former for samfunnsengasjement, ytringsfrihet, hatefulle ytringer, tillit og velferdsholdninger. Han er prosjektleder for den siste undersøkelsen om frivillig innsats i Norge (2017/2018) og har blant annet publisert i tidsskrifter som Journal of European Social Policy, Scandinavian Political Studies, Scandinavian Journal of Educational Research og Nordicom Review.

Steinar Gjerde (Master, statsvitenskap) er forskningsassistent ved Institutt for sammenlignende politikk, Universitetet i Bergen. Han har i perioden 2012 til 2017 hatt flere engasjement som forskningsassistent både ved Institutt for Sammenliknende Politikk og ved Uni Research Rokkansenteret tilknyttet Senter for forskning på sivilsamfunn og frivillig sektor. Hans publikasjoner inkluderer rapportene Frivillig deltakelse i Norden - Et komparativt perspektiv, med Arnesen og Folkestad (2013), Bruk av frivillige i søk og redning: En pilotstudie i to politidistrikt, med Winswold (2016) og Frivillige organisasjoner $i$ søk og redning: Utvikling, rekruttering og samarbeid med kommunene, med Winswold (2017).

Jørn Ljunggren er PhD i sosiologi og postdoktor ved Institutt for sosiologi og samfunnsgeografi ved UiO. Ljunggrens forskningsinteresser er knyttet til sosial ulikhet i bred forstand. Spesielt spørsmål om klasse, kjønn og etnisitet. Han har blant annet vært redaktør for bøkene Oslo - ulikhetenes by (2017) og Klassebilder (2010).

Kari Steen-Johnsen er forskningsleder ved Institutt for samfunnsforskning. Hennes forskning er sentrert rundt endringer i sivilsamfunnet i bred forstand. Hennes interesser inkluderer temaer som politisk mobilisering og deltagelse, offentlig debatt og ytringsfrihet, med vekt på konsekvenser av digitalisering og fremvekst av sosiale medier. Hun har også forsket på endringer i lokale frivillige fellesskap og hvordan frivillige organisasjoner utvikler seg i lys av samfunnsendring. Steen-Johnsen har vært knyttet til Senter for forskning på sivilsamfunn og frivillig sektor siden 2009, hvor hun blant annet har forsket på frivillige organisasjoner og digitalisering, og på sivilsamfunnets rolle i integrering i lokalsamfunn. Blant de siste årenes publikasjoner i norsk kontekst er boken Liker-liker ikke. For 
tiden jobber hun blant annet med et komparativt prosjekt som undersøker de samfunnsmessige konsekvensene av terrorisme i Norge, Frankrike, Spania, USA og Finland (Disruption, Social Capital and Resilience). Hun har hovedfag i sosiologi fra Universitetet i Oslo, og doktorgrad fra Norges idrettshøgskole.

Kristin Strømsnes (Dr.polit, statsvitenskap) er Professor ved Institutt for sammenliknede politikk, Universitetet i Bergen og har bistilling som Forsker 1 ved NORCE Samfunn Hennes forskningsinteresser inkluderer temaer som politisk deltakelse og mobilisering, frivillig organisering og sosial kapital, forholdet mellom stat, marked og frivillig sektor, samt den skandinaviske sivilsamfunnsmodellen. Hun var en av initiativtakerne da Senter for forskning på sivilsamfunn og frivillig organisering ble etablert i 2008, og fungerte som forskningskoordinator for senteret den første femårsperioden. Blant hennes siste publikasjoner er bøkene Civic Engagement in Scandinavia. Volunteering, Informal Help and Giving in Denmark, Norway and Sweden (Springer 2019, redigert sammen med Lars Skov Henriksen og Lars Svedberg) og Scandinavian Civil Society and Social Transformations. The Case of Norway (Springer 2018, redigert sammen med Bernard Enjolras). Strømsnes er for tiden gjesteforsker ved Harvard Kennedy School, Ash Center for Democratic Governance and Innovation.

Synne Sætrang (Master sosiologi) er tidligere vitenskapelig assistent og prosjektrådgiver ved Institutt for samfunnsforskning og Senter for forskning på sivilsamfunn og frivillig sektor. Jobber nå som frivilligkoordinator $\mathrm{i}$ Kirkens Bymisjon (Stovner Frivilligsentral). Hennes forskningsinteresser inkluderer temaer som frivillig innsats, integrasjon og sosial kapital. Hun er blant annet medforfatter av rapporten Betingelser for frivillig innsats motivasjon og kontekst og forfatter av rapporten "Ikke bare en Facebookgruppe"- En casestudie av Refugees Welcome-nettverket $i$ Norge.

Marianne Takle (ph.d statsvitenskap) er forsker I ved NOVA, OsloMet - Storbyuniversitetet. Hennes forskningsinteresser omfatter EU's migrasjonspolitikk, nasjonal migrasjonspolitikk i utvalgte europeiske land, nasjonalisme, solidaritet og sivilsamfunnsstudier. Hun har blant annet 
skrevet boken Politisk integrering. Innvandrerorganisasjoner som skoler i demokrati og byråkrati (Cappelen Damm Akademisk, 2014), og bidratt til bøkene Diversity and Contestations over Nationalism in Europe and Canada (Palgrave Macmillan, 2018) og The Challenge of Europe - New Perspectives and Analyses on a Troubled Project (Routledge 2018).

Guro Ødegård (ph.d sosiologi) er forsker ved NOVA-OsloMet og leder Seksjon for ungdomsforskning. Hennes forskningsinteresser penser rundt temaer som sivilsamfunn og demokrati, hvilket inkluderer studier av frivillig organisering i flerkulturelle lokalsamfunn, politisk deltakelse og samfunnsengasjement blant unge generelt og unge med innvandrerbakgrunn spesielt. Ødegård ledet det offentlige utvalget «Statlig støttepolitikk for frivillige barne- og ungdomsorganisasjoner» og er medlem av utvalget «Levekårs- og integreringsutfordringer i byområder». 